UNIVERSIDADE DE SÃO PAULO

PROGRAMA DE PÓS-GRADUAÇÃO INTERUNIDADES EM MUSEOLOGIA

KARINA ALVES TEIXEIRA

O Patrimônio Imaterial sob a ótica dos museus: novas aproximações, perspectivas e rupturas.

São Paulo

2014 
Karina Alves Teixeira

O Patrimônio Imaterial sob a ótica dos museus: novas aproximações, perspectivas e rupturas.

Dissertação apresentada ao Programa de Pós-Graduação Interunidades em Museologia da Universidade de São Paulo para obtenção do título de Mestre em Museologia.

Área de Concentração: Museologia

Orientador(a): Prof. (a) Dr.(a)

Maria Cristina Oliveira Bruno

Linha de Pesquisa: Teoria e método da gestão patrimonial e dos processos museológicos

Versão original

São Paulo

2014 
Autorizo a reprodução e divulgação total ou parcial deste trabalho, por qualquer meio convencional ou eletrônico, para fins de estudo e pesquisa, desde que citada a fonte.

Teixeira, Karina Alves.

O Patrimônio Imaterial sob a ótica dos museus: novas aproximações, perspectivas e rupturas / Karina Alves Teixeira; orientador Maria Cristina Oliveira Bruno. São Paulo, 2014.

170 f. : il. color ; $30 \mathrm{~cm}$.

Dissertação (Mestrado) - Programa de Pós-Graduação Interunidades em Museologia do Museu de Arqueologia e Etnologia da Universidade de São Paulo, 2014.

1. Patrimônio Imaterial. 2. Museus. 3. Memoriais. 4. Memorial da Resistência de São Paulo. 5. Museologia. I. Bruno, Maria Cristina Oliveira. II. Programa de Pós-Graduação Interunidades em Museologia da Universidade de São Paulo. III. Título. 
Nome: Karina Alves Teixeira

Título: O Patrimônio Imaterial sob a ótica dos museus: novas aproximações, perspectivas e rupturas

Dissertação apresentada ao Programa de Pós-Graduação Interunidades em Museologia da Universidade de São Paulo para obtenção do título de Mestre em Museologia.

Aprovado em:

Banca Examinadora

Prof.Dr. Instituição:

Julgamento:

Assinatura:

Prof.Dr. Instituição:

Julgamento: Assinatura:

Prof.Dr. Instituição:

Julgamento: Assinatura: 


\section{Agradecimentos}

Saber agradecer é tão importante quanto saber viver. Começo agradecendo à vida e à Fonte a oportunidade de aprendizado e crescimento na conclusão de mais esta etapa.

Agradeço a Profa. Heloisa Barbuy por sua confiança e disponibilidade inestimável para meu ingresso no Programa.

Agradeço a Profa. Maria Cristina Oliveira Bruno, por primeiro acolher meu projeto de braços abertos, e depois pela constante e paciente orientação em todo percurso.

Agradeço a Coordenadora do Memorial da Resistência, Kátia Regina Felipini Neves, pelo constante apoio e abertura para realização desta pesquisa, como museóloga e como chefe, nas inúmeras necessidades encontradas no percurso.

Agradeço a toda equipe do Memorial da Resistência pelas infinitas trocas, descobertas e aprendizados construídos juntos em nosso dia-a-dia.

Agradeço aos Professores Marília Xavier Cury e Julio Naranjo Moracen pelas imprescindíveis e sábias contribuições que forneceram ao meu trabalho. E a Professora Marília, em especial, por tantas outras contribuições e auxílios recebidos.

Agradeço ao fraterno e honrado coração dos militantes e eternos resistentes que aceitaram contribuir com esta pesquisa, mas acima de tudo, pelo aprendizado e carinho que me dedicaram. É uma dádiva conhecê-los e crescer com vocês.

Agradeço aos amigos queridos que acompanharam, incentivaram e tornaram possível o início desta aventura e se fazem presentes em tantos momentos: Ademir Takara, Nahema Falleiros, Aira Bonfim, Paulo Nascimento, Mônica Saraiva, Daniela Alfonsi, Diego Viñas. 
Agradeço à minha família querida a compreensão e paciência em tantas ausências.

Agradeço aos amados presentes recebidos nesta jornada Luiz Mizukami, Paulo Nascimento, Viviane Wermelinger, Agda Sardinha, Ana Carolina Ávila, Thais Araújo.

Agradeço aos queridos, presentes de muito perto ou de longe, com quem posso sempre contar: Lilian Ramadan, Camilo Flamarion, Gilberto Francisco, Mojana Vargas, Daniela M.Amaral, Leandro Pinheiro.

Agradeço a você irmã querida, Livia Rachel. Sem você, seu amor incondicional e força e vibração nada teria sido tão possível, tão rico, tão milagroso.

Agradeço ao Dr. Jacob e ao Sr. Luiz pelo auxílio fundamental na etapa final. Agradeço a Karen Ribeiro, Regina Silva, Cléberson de Moura, Aline Garcia.

Agradeço aos vários amigos que ajudaram de diversas e inumeráveis formas. Para todos os agradecimentos muitas páginas se fariam necessárias. Muitos contribuíram e tornaram possível o caminhar desta jornada até aqui. A todos vocês meu muito obrigada.

Gratidão e Reconhecimento Eternos. 
“BOA TERRA EM TEUS PÉS,

ÁGUA O BASTANTE EM TUA SEMENTE,

BOM VENTO PARA O TEU SOPRO,

FOGO EM TEU CORAÇÃO

E MUITO AMOR EM TEU SER" 


\title{
O Patrimônio Imaterial sob a ótica dos museus: novas aproximações, perspectivas e rupturas.
}

\begin{abstract}
RESUMO
O presente trabalho tem como objeto de estudo o patrimônio intangível ou imaterial e suas formas de musealização. Sendo os museus lugares máximos de presença do patrimônio, visa-se descobrir, identificar e metrisar as relações construídas entre os bens imateriais ou intangíveis e esses espaços. Para tanto a investigação parte da historicidade da definição de patrimônio, e em como se vinculam patrimônio material e imaterial. Em um segundo momento, o objeto de estudo é analisado in locu, no Memorial da Resistência de São Paulo, onde se aplica a parte experimental da pesquisa, e que correspondente ao seu terceiro momento, com o intuito de identificar como o imaterial é musealizado e como ele é percebido por seus públicos. Para tanto o foco da análise recai sobre o Programa Coleta Regular de Testemunhos, pois por meio dele o museu coleta a referência patrimonial a qual se dedica e constrói os processos museológicos do Memorial da Resistência de São Paulo. Deste modo, é empreendida uma análise das intenções do programa, sua relação com as demais linhas programáticas, e seus resultados verificados na exposição, por meio de fontes institucionais e avaliações de público. Por fim, uma análise mais geral busca localizar a participação dos atores sociais e agentes da memória nos processos de preservação.
\end{abstract}

Palavras-Chave: Patrimônio Imaterial. Museus. Memoriais. Memorial da Resistência de São Paulo. Museologia. 


\begin{abstract}
The Intangible Heritage from the perspective of museums: new approaches, perspectives and ruptures

The present work has as its studied objetc the imaterial or intagible heritage and their ways of musealization. Being the museums the maximum places of heritage presence, we aim to discover, identify and measure the built relationships between the immaterial or intangible assets and those spaces. To attend this purpose the research begins from the historicity of the definition of heritage, and how is the binding between tangible and intangible heritage. In a second step, the object of study is analyzed in locus in the Memorial of Resistance of São Paulo, where it is applied the experimental part of the research, and that corresponds to the third point of this research, in order to identify how the intangible is musealized and how it is perceived by its stakeholders. To do this the focus of analysis is on the Program of Regular Collection of Testimonies, because through it the museum collects the heritage reference in which works and builds the Memorial of Resistance of São Paulo's museological processes. Thus, an analysis is undertaken of the intentions of the program, its relationship with other programmatic lines, and their verified results on exhibition through institutional sources and reviews of public. Finally, a more general analysis seeks to locate the participation of social actors and memory agents on preservation processes.
\end{abstract}

Key Words: Intangible Heritage. Museums. Memorials. Memorial of Resistence of São Paulo. Museology. 


\section{LISTA DE SIGLAS E ABREVIATURAS}

$\begin{array}{ll}\text { APAC } & \text { Associação Pinacoteca Arte e Cultura } \\ \text { CNRC } & \text { Centro Nacional de Referência Cultural } \\ \text { INRC } & \text { Inventário Nacional de Referências Culturais } \\ \text { CNM } & \text { Cadastro Nacional de Museus } \\ \text { ICOFOM } & \text { Comitê Internacional para a Museologia do Conselho } \\ & \text { Internacional de Museus } \\ \text { ICOM } & \text { Conselho Internacional de Museus } \\ \text { ICOM BRASIL } & \text { Comitê Brasileiro do Conselho Internacional de Museus } \\ \text { ICOFOM LAM } & \text { Subcomitê Regional do ICOFOM para América Latina e Caribe } \\ \text { IPHAN } & \text { Instituto do Patrimônio Histórico e Artístico Nacional } \\ \text { MinC } & \text { Ministério da Cultura } \\ \text { MINOM } & \text { Movimento Internacional para uma Nova Museologia } \\ \text { MRSP } & \text { Memorial da Resistência de São Paulo } \\ \text { PCI } & \text { Patrimônio Cultural Imaterial } \\ \text { PCRT } & \text { Programa Coleta Regular de Testemunhos - MRSP } \\ \text { PNM } & \text { Política Nacional de Museus } \\ \text { SPHAN } & \text { Secretaria de Patrimônio Histórico e Artístico Nacional (de 1979 - } \\ \text { SEC } & \text { Secretaria de Cultura do Estado de São Paulo } \\ \text { UNESCO } & \text { Organização das Nações Unidas para Educação Ciência e } \\ & \text { Cultura }\end{array}$




\section{Sumário}

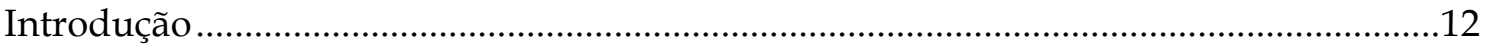

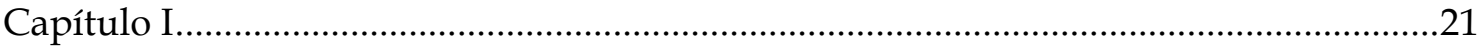

Sobre as Noções de Patrimônio Cultural: entre o tangível e o intangível .........................21

1.1 - A historicidade e a evolução do pensamento em torno dos bens culturais ...21

1.2 - Estado da Arte: o Patrimônio Imaterial dentro e fora dos museus ........................30

1.3 - O imaterial ou intangível: a construção de um conceito ...........................................36

1.4 - A memória e o direito à memória ...............................................................................43

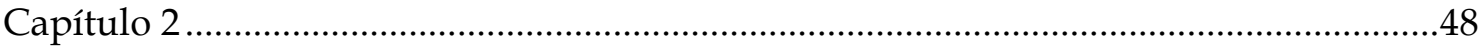

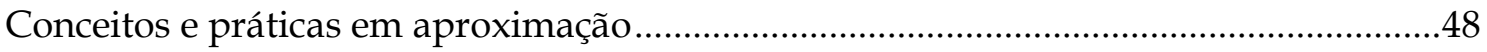

2.1 - No contexto do objeto: as ditaduras, a Justiça de Transição, as políticas de memória e a patrimonialização de locais de dor .............................................................4.

2.2 - O Memorial da Resistência de São Paulo .............................................................50

2.2.1 - Breve histórico institucional............................................................................50

2.2.2 - Estrutura museológica ........................................................................................57

2.2.3 - O Programa Coleta Regular de Testemunhos ...................................................61

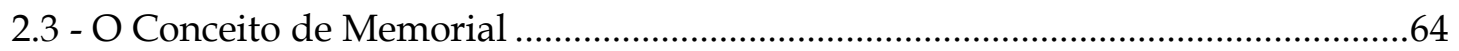

2.4 - Os Memoriais na paisagem museológica brasileira .................................................70

Capítulo 3 - A experimentação: construção da pesquisa e do conhecimento acerca do

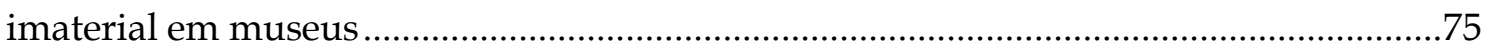

3.1 - Análise do Programa Coleta Regular de Testemunhos ..........................................77

3.2 - Estratigrafia Social: a forma de ver e perceber dos agentes da memória patrimonializada, ou do patrimônio imaterial em questão............................................96

3.3 - Estratigrafia institucional: diagnóstico da ação preservacionista.........................114

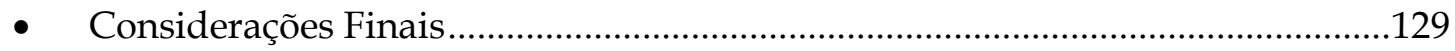

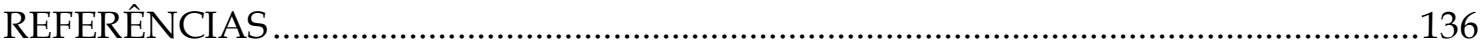

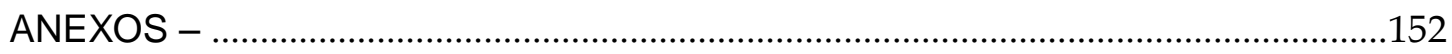




\section{Introdução}

O amor pelo imaterial nasceu do desejo profundo de se aproximar das gentes e da vida em seus ritmos e movimento constante. Daquilo que pode e faz a vida ter valor e calor. Da vida onde pulsa seu verdadeiro ritmo: a cultura.

Daí para a acepção deste trabalho uniu-se paixões a muitas inquietações e muitas buscas frente ao patrimônio. Intrínseca a uma visão de patrimônio integral, originado pela natureza e pelo homem, presente em toda parte, de diversas formas, cada vez mais a vida nos e dos museus me empurrava para fora dele, para o mundo extra-muros, para o que existe e é feito além dos muros dos museus. Isso em grande parte, por denotar e me inquietar pela profunda distância que os patrimônios musealizados ainda têm da maioria da população, onde ainda impera a crença de que museu é lugar de coisa velha.

Mesmo com tantos avanços da museologia social $\mathrm{e}$ todas as novas museologias que vêm sendo criadas a partir do século $X X$, a maior parte dos museus ainda não consegue trazer para si as comunidades, como um lugar efetivamente considerado seu. E seus públicos se relacionam com espaços museais de forma pontual visitando suas exposições como principal forma de contato. Sobretudo, claro, em se tratando dos grandes museus, e salvo as experiências museais bem sucedidas nesse sentido.

\section{Por que esta distância?}

Ao cunhar a nomenclatura oficial para patrimônio imaterial, em contexto nacional ou internacional, proliferaram-se iniciativas e políticas específicas para tal, e muitas acontecem fora dos museus. Isso pode dar a impressão de que o patrimônio imaterial existe como uma manifestação independente. Mas basta lembrar que o imaterial sempre foi matéria dos museus, e eles estão sintonizados com as mudanças do espectro patrimonial em termos de conceitos, categorias e legislação, ou dos contextos sociais.

Diante disso, o tema escolhido para esta dissertação de mestrado foi uma construção que perpassa minha formação e atuação profissional. Desde o início de minha graduação em História comecei a adentrar o universo dos museus e da 
pesquisa histórica em paralelo. E em temas que vem se juntar na presente pesquisa, a saber, memória; história oral; ditadura; patrimônio; educação patrimonial e museologia. ${ }^{1} \mathrm{E}$ vale destacar que o lócus escolhido para pesquisa acompanha minha atuação profissional, fazendo deste trabalho de pesquisa um laboratório. E que permite uma práxis reflexiva por meio da pesquisa participante, favorecendo a abordagem museológica enquanto ciência aplicada. Hoje atuo profissionalmente no Memorial da Resistência de São Paulo ${ }^{2}$. Isto acrescentou muitos desafios ao tema geral dadas as especificidades do museu em questão. Por outro lado, somou dada a característica muito particular do Memorial da Resistência, uma instituição jovem, mas já com trabalho consolidado. E que, ao mesmo tempo, busca alicerçar todos os programas e processos da cadeia museológica, de modo a atingir sua expansão e autonomia, assim como, o cumprimento da missão institucional, voltada para construção da cidadania e a educação em direitos humanos.

Assim, a pesquisa proposta insere-se na construção do "olhar museológico". $E$, acima de tudo, nas premissas que envolvem o vínculo entre bens patrimoniais e sociedade. Pois, deve ser este o objetivo maior da museologia, e de seus profissionais, mediadores desse processo. Em meu tema, fez-se necessário o entendimento das delimitações de um processo museológico, em que ele consiste e a forma como se dá, até chegar a uma metodologia de tratamento desse bem para sua preservação por meio da cadeia museológica. Em se tratando de patrimônio imaterial, temos alargados os conceitos de patrimônio, e temos também a defrontação com novos paradigmas para o olhar e fazer museológicos. Partir da rediscussão da noção de patrimônio é um primeiro ponto. Mas, uma vez tomado como bem selecionado, precisam ser acionados princípios teóricos e metodológicos da museologia. Princípios que posicionam a nós profissionais como mediadores desse processo, e que inclui a seleção desses bens, a escolha de métodos e técnicas para lhe dar um tratamento

\footnotetext{
${ }^{1}$ Participei, desde então, de encontros e disciplinas sobre temas citados entre os quais a iniciação científica "Imagens e Palavras construindo realidades. A Fotografia como instrumento político do Deops (1924-1945)", sob orientação do Prof. Dr. Boris Kossoy (ECA/USP) e co-orientação da Profa. Dra. Maria Luiza Tucci Carneiro(FFLCH/USP), integrantes do Proin (Projeto Integrado Arquivo de Estado e Universidade de São Paulo), via Projeto Temático da FAPESP; o Curso de Especialização em Museologia (março de 2005 a julho de 2006, total 825 horas), com monografia que propunha a patrimonialização/musealização do tema e do acervo DEOPS/SP; e os trabalhos realizados especialmente no Id Bairro SP\#02 Bom Retiro (2011) e Centro de Referência do Futebol Brasileiro (CRFB) - Museu do Futebol (2011-2013).

${ }^{2} \mathrm{O}$ lócus inicialmente escolhido foi o CRFB, do Museu do Futebol. E foi transferido juntamente com minha mudança de " casa ". No Memorial da Resistência atuo como Pesquisadora Sênior, com a missão de auxiliar no desenvolvimento das três linhas museológicas de pesquisa da Instituição : Programa Coleta Regular de Testemunhos, Programa Lugares da Memória e Centro de Referência.
} 
patrimonial, fazer sua significação e retorná-los à sociedade para total usufruto de suas heranças. Uma vez que a tarefa dos museus consiste, exatamente, em realizar a pedagogia da memória no sentido de levar as pessoas a reconhecerem suas memórias como um patrimônio, uma herança comum.

Por meio de um contexto de musealização, apliquei a observação empírica para identificar o processo de tratamento dos bens selecionados - sua valorização como herança, e formas para sua difusão. Identificação, seleção, herança e patrimônio, tratamento metodológico são questões chaves de meu tema e objeto de estudo. Pois, meu trabalho consiste exatamente na delimitação dessas chaves ao falar de bens imateriais nos contextos musealizados, e os métodos que instituições museais estão adotando para seu tratamento e apresentação. Um dos temas de ruptura da museologia tem sido o debate entre patrimônio material e imaterial e, por conseguinte, o repensar das práticas, a começar pela existência ou não de acervos em museus.

O tema selecionado para estudo é o patrimônio imaterial. Desse universo, a pesquisa intitulada "O Patrimônio Imaterial sob a ótica dos Museus: novas aproximações, perspectivas e rupturas.", pretende analisar o patrimônio imaterial e sua interface com instituições museais, e mais precisamente, como o imaterial está inserido no contexto museal escolhido. E para observação dessa relação na realidade museal em curso, o Memorial da Resistência de São Paulo.

Para tanto, é proposta uma ousada forma de olhar para o objeto de estudo que se coloca: enxergar a conexão entre bens imateriais, agentes culturais, museus e patrimonialização, considerando não apenas o processo de musealização, como também, a sociedade, ou o público que dele usufrui.

Como diz a própria definição de patrimônio imaterial - patrimônio constituído pelos saberes, ofícios, festas, rituais, expressões artísticas e lúdicas, produzidas e vivenciadas pela tradição de indivíduos ou grupos, como expressão de sua identidade cultural e social, reconhecida como tal por esses próprios grupos (Iphan, 2000; UNESCO, 2003) - este precisa ser reconhecido como tal pelos grupos que os produzem ou vivenciam. Assim, torna-se condição que qualquer estudo a seu respeito considere atores e práticas culturais, ou mesmo parta deles, para uma compreensão adequada.

Falar em intangível remete àquilo que não pode ser palpável ou medido. A matéria prima dessa categoria de patrimônio reside nas expressões, práticas e 
manifestações culturais, em grupos, em pessoas. Pessoas que no fazer de sua prática produzem suportes e representações materiais dessa cultura. Essa é uma lógica que subverte totalmente a lógica natural dos museus, que primeiro recebe o material para, depois de neutralizar sua degradação natural, cuidar dos elementos imateriais neles contidos. Como então lidar com tal aparente contradição?

Para responder a estas indagações a investigação deste projeto percorrerá o caminho do imaterial: da prática cultural, contextualizada no local onde ela aconteceu no passado e onde acontece no presente, mapeando seu percurso de musealização. Para chegar à relação entre o imaterial/intangível e a concretude da preservação museal, a estratégia adotada coloca em paralelo os atores e autores de práticas culturais com as ações patrimoniais que os musealizam. Dentro da trama imbricada de temas transversais relacionadas à questão principal, estão as relações entre memória, patrimônio, herança cultural, bens culturais, identidade(s), representações, direitos humanos, e lugares de memória ligados aos regimes ditatoriais no Brasil.

Onde estarão atores, práticas culturais e o intangível dentro dos museus?

Como abarcar a complexa realidade do universo escolhido?

As leis que regem o patrimônio imaterial o colocam como um elemento reconhecido como parte do patrimônio cultural por comunidades grupos ou indivíduo. Qual o processo desse reconhecimento? São antes reconhecidos pelo grupo ou pela instituição que o chancelará como um patrimônio?

Diante desse quadro, o problema central desdobra-se nos seguintes questionamentos: Quais os efeitos da salvaguarda? Quais as consequências das ações de salvaguarda preservacionista? Ela contribui para o desenvolvimento humano, cultural, social, econômico, de uma localidade, ou território, e da comunidade que o ocupa?

Sobre o tema, parte-se do conceito que o intangível é o novo valor a ser agregado ao modo de vida humano. Esse valor instaura novos sistemas onde a cultura, o conhecimento e o potencial criativo humano serão seus novos paradigmas fundadores. A cultura e todo seu capital intangível são, para nós, veículo de transformação e desenvolvimento. Dentre esses capitais, o patrimônio cultural será uma de suas maiores "moedas".

De legado recente, o patrimônio imaterial já tem sido largamente estudado. Porém esses estudos concentram-se nos marcos regulatórios, políticas e dilemas da 
aplicação das leis de preservação do patrimônio material, passando por sua origem, trajetória, conceitos e métodos de salvaguarda adotados, sobretudo pelos órgãos oficiais.

Pouco se sabe sobre os resultados e alcance das políticas adotadas. Para além das ações, não se encontram quase registros sobre os praticantes das manifestações culturais, principais vetores de sua existência e manutenção, bem como qualquer aferição das políticas de preservação sobre práticas e praticantes.

Um leque representativo de estudos pontuais que façam a relação entre o imaterial e os museus é encontrado somente em outros países, sobretudo, França, Portugal, Alemanha e Inglaterra. No Brasil, mesmo havendo uma marcante presença da inclusão do imaterial nos documentos de órgãos nacionais, internacionais e da museologia e, por outro lado, de alguns encontros de especialistas sobre o tema, o imenso terreno das práticas em torno do imaterial fora dos órgãos oficiais é desconhecido. Do lado dos órgãos museológicos vemos encontros e medidas dentro da Cátedra da Unesco e ICOM, e um importante encontro realizado pelo ICOFOM LAM já em finas da década de 1990.

O objetivo geral consiste em identificar, conhecer e compreender os usos do patrimônio imaterial em museus para, a partir de um conhecimento sistêmico, analisar ações patrimoniais em curso, e refletir sobre seus resultados. Tal ação visa lançar novas contribuições e propostas que transformem a cultura e o patrimônio em vetores de transformação e desenvolvimento. Por objetivos específicos toma-se a investigação de metodologias de avaliação para processos museológicos, voltados a preservação de bens intangíveis.

As hipóteses alvitadas são: a oralidade e a memória constituem base para a construção de um acervo, a oralidade pode ser base para uma referência patrimonial, para a pesquisa, e para a construção de processos museológicos.

O conhecimento dos novos processos museológicos de salvaguarda dos bens culturais intangíveis elucidará o desenvolvimento da museologia enquanto campo de conhecimento. Isso trará mais informações de como potencializar o processo de mediação entre patrimônio e sociedade. Portanto, as análises estarão centradas nos processos e metodologias museológicos, bem como o alcance das ações museológicas em questão. Acompanhado, em igual medida, do levantamento de dados que evidenciem inserções e ponto de vista dos agentes culturais da prática 
patrimonializada. Deste modo, o recorte será dado nas seguintes categorias de público:

- Público de ex-presos políticos, militantes e outros diretamente relacionados com o tema. Deste público há grupos que já participam intensamente do Memorial desde sua formação e outros que não mantém contato direto com a instituição. E outros que vêm paulatinamente participando dos Programas do Memorial, a exemplo do Programa de Pesquisa Coleta Regular de Testemunhos.

- Público interno: profissionais envolvidos com o Memorial da Resistência.

- Outros públicos contemplados pelas avaliações museológicas institucionais.

Ulizar-se-á como fontes os documentos e pesquisas institucionais de público realizadas pela própria instituição ou por comandatários a ela ${ }^{3}$, a produção (testemunhos) e metodologias do Programa de Coleta Regular de Testemunhos, questionários qualitativos específicos aos ex-presos e entrevistas, documentos de órgãos oficiais de preservação (nacional e internacional) e imprensa; balizadas entre 2008 (início do projeto de implantação do MRSP) e julho de 2014 (data limite desta pesquisa). Com base na análise documental institucional, da literatura já produzida, e a saída a campo, pretende-se chegar à análise crítica e avaliativa da realidade em evidência, por abordagem interdisciplinar inerente à museologia.

Além dos teóricos escolhidos, faz parte do escopo do projeto examinar nosso estudo de caso em interface ao tratamento dispensado ao patrimônio cultural imaterial brasileiro e do estado de São Paulo em particular, posto que o Memorial da Resistência pertence à administração do governo estadual e suas políticas de cultura. Alguns projetos museológicos e outras ações, onde patrimônio imaterial seja o foco, foram incluídos para análise comparativa. Deles pretende-se reunir um arcabouço de informações que contribuam a métodos de avaliação, formulação de indicadores culturais e políticas públicas. A análise segue, portanto, o seguinte esquema:

\footnotetext{
${ }^{3}$ Tratam-se do Plano e Programa Museológico, Catálogo Institucional, Avaliações de Público realizadas pela própria instituição ou por prestadores especializados contratados.
} 


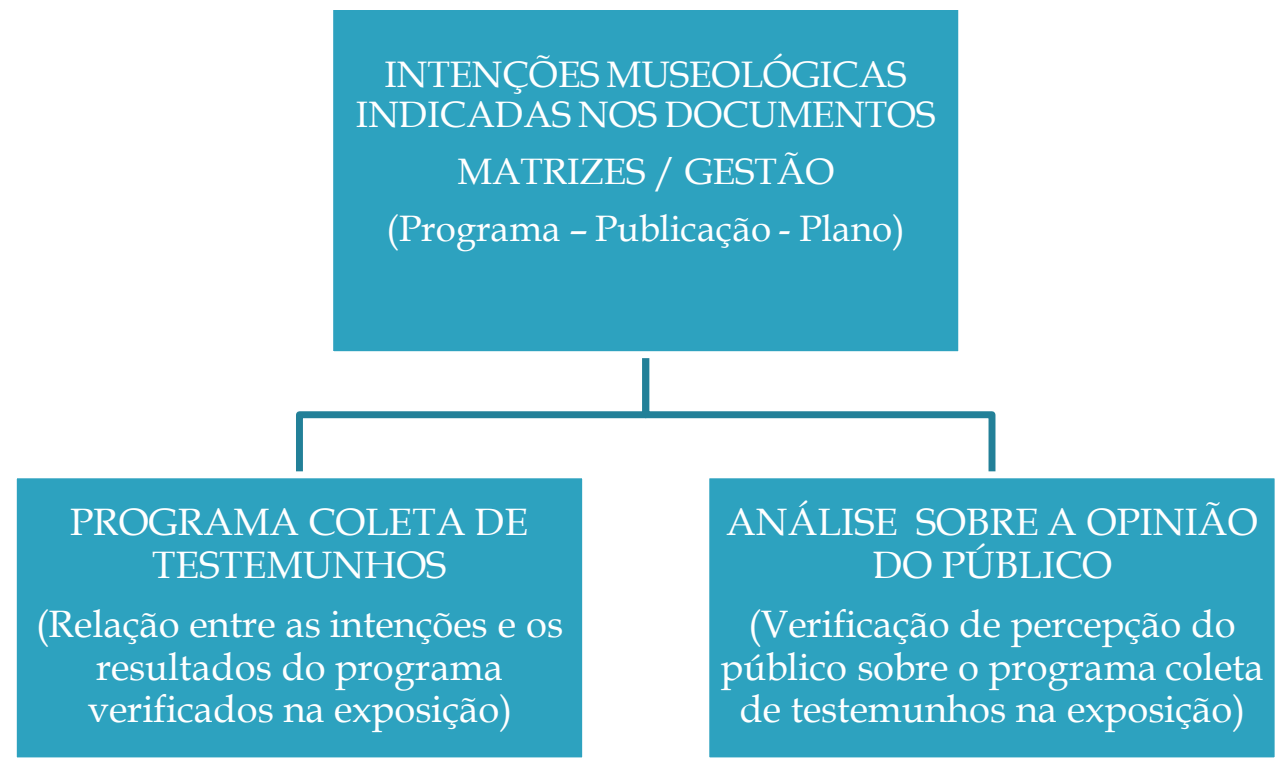

Para aprofundar esse processo de análise crítico-avaliativo empregar-se-á conjuntamente a análise de processos, com auxilio da metodologia de diagnósticos e avaliações museológicos. Processo é também um conceito chave para nós: fenômenos e fatos museológicos ligados aos objetos em questão são entendidos como um processo. Processo não apenas no sentido de sua construção social, mas de objetos que estão em constante dinâmica e mutação, e que evoluem processualmente no tempo e no espaço, tal é o caso das dinâmicas das práticas culturais.

O Memorial comporta a musealização de um lugar de memória, bem como a identificação e musealização de referências patrimoniais imateriais, criando novas metodologias para empreendê-lo. Nesta dinâmica os testemunhos orais são utilizados em diferentes âmbitos e, portanto, a oralidade passa a uma visão ampliada do patrimônio. Portanto a oralidade será um norte chave neste trabalho.

Deve ficar claro ao leitor que a intenção é entender como o imaterial é inserido neste museu, a partir do primeiro e principal público - ex-presos(as) políticos relacionados ao lugar e ao tema. À guisa de completude, este lócus implica a introdução do tema no quadro da Justiça de Transição e das lutas daqueles que sofreram violações durante os períodos ditatoriais no Brasil. Trata-se de processos de resignificação do passado e uma causa social muito ativa: a luta pelo direito à memória, verdade e justiça. Por isso, toda problemática só poderá ser bem compreendida se inserida nas políticas públicas de memória e da preservação da memória política em crescimento no país. O que está em jogo é um contexto novo de 
patrimonialização de memórias políticas, memórias de violações de direitos humanos, e memórias de dor.

Espera-se tirar desta experimentação empírica elementos que elucidem como as metodologias podem contribuir para a aproximação do público com os museus e os bens que salvaguardam. A análise dos dados obtidos pode proporcionar elementos e informações que contribuam a formulação de indicadores e políticas culturais aos bens intangíveis e aos museus, além de se tornar uma experiência cambiável.

A dissertação ora apresentada é composta por três capítulos. O Capítulo 1 trata dos conceitos de patrimônio, sua historicidade e evolução, a contextualização do patrimônio imaterial e um ensaio para uma conceitualização de imaterial por nós proposta, e um breve tópico sobre memória e memória social, tema transversal a toda problemática e objeto de estudo em questão.

O capítulo 02 começa apresentando o contexto da patrimonialização de locais de memória ligados a violações de direitos humanos e experiências de dor. Isto para introduzir o contexto atual no qual se insere o lócus desta pesquisa, o Memorial da Resistência de São Paulo. Os tópicos seguintes fazem um breve histórico da instituição, apresenta sua estrutura museológica e o Programa dedicado à coleta de testemunhos. Inclui também uma reflexão sobre a definição e caráter dos Memoriais e, em particular, dos Memoriais de Resistência, em contexto internacional e nacional.

O capítulo 3 depende essencialmente da aplicação da pesquisa empírica e seu cruzamento com outras fontes e arcabouço teórico. Ela apresenta os dados colhidos na pesquisa construída a partir do multimétodo, das metodologias de diagnóstico e avaliação museológicos. Após o arrolamento dos dados, seguem tópicos que aplicam esses dados em análise prospectiva para resposta dos objetivos e hipóteses levantados. As considerações finais apresentam um balanço geral, fechando as reflexões e resultados alcançados na experimentação proposta.

Todo arcabouço reunido para esta pesquisa de mestrado baseia-se na crença de que o humano deve ser o foco de toda ação patrimonial, acima de tudo. Na crença de que a cultura e o patrimônio são os vetores principais de transformação e desenvolvimento local, universal, humano. Por desenvolvimento, adotamos uma noção de desenvolvimento integral, em termos de práticas sociais, entendido como o desenvolvimento do sentimento de pertencimento, identidade e inclusão (afetiva, intelectual, humana, social); o desenvolvimento local, social, econômico e ambiental 
para a melhoria da qualidade de vida e o desenvolvimento através de usos sustentáveis dos recursos capitais humanos e patrimoniais.

Reapropriar-se de valores, saberes, tradições e conhecimento é o primeiro passo de importância fundamental nos contextos atuais e na realidade brasileira. A riqueza do país está na sua diversidade cultural e esta deve ser a ponta de lança. A diversidade, sempre acompanhada da criatividade e da fonte inesgotável que vem do humano, é uma das saídas aos anseios de transformação. 


\section{Capitulo I}

\section{Sobre as Noções de Patrimônio Cultural: entre o tangível e o intangível}

\section{1 - A historicidade e a evolução do pensamento em torno dos bens culturais}

O mundo ocidental tem por praxe elaborar noções universais a partir das quais são regidas políticas, leis e comportamentos. Estas noções são historicamente construídas e, portanto, tem ligação direta com um momento histórico e ideários localizados. Entre todas as áreas, a área do patrimônio cultural é onde isso pode se verificar com muita força, pois os patrimônios da humanidade são guiados por tais noções e regulações, em níveis nacionais e internacionais.

Junto à noção de patrimônio vem a de preservação, afinal é necessário preservar ao máximo o tesouro de imenso valor considerado um patrimônio. Patrimônio e preservação caminham juntos e carregam em si um processo de seleção e valorização de bens que integram os patrimônios históricos, artísticos, culturais nacionais e internacionais.

Cada país tem uma origem própria e linguística do termo patrimônio e do uso que Ihe atribui. Mas, em todas temos em comum o caráter de legitimação de um bem, uma herança que se considera comum: um sentimento de bens fundamentais, notáveis e inalienáveis que unem que contem os traços de origem comum e riqueza moral, da humanidade ou da nação ${ }^{4}$.

A acepção do termo é mais antiga, originária do direito romano, e expressa um conjunto de bens transmitidos, segundo a lei, para os descendentes de uma família. Levada ao campo cultural, a primeira menção conhecida do termo "patrimônio cultural" teria surgido no século XVII. Já a Itália utilizou a expressão "bens culturais". A Inglaterra utilizou o termo propertye somente em 1950 o termo herança. Desvallées menciona que a noção que conhecemos do termo ganhou amplidão maior no mundo latino a partir da década de 1930.

\footnotetext{
${ }^{4} \mathrm{O}$ poder das palavras, segundo Bordieu, de manter uma ordem ou a subverter, é dado pela crença na legitimidade dessas palavras e de quem as pronuncia, crença que estrapola a palavra em si mesma, assentada em outros fatores. (Bourdieu, 1989, p.14-15)
} 
Mais que a etimologia do termo, importa frisar que as noções vão ganhando espaço mediante as demandas históricas em cada contexto:

"O patrimônio é uma maneira de viver as rupturas, de reconhecê-las e reduzilas, referindo-se a elas, elegendo-as, produzindo semióforos. Inscrito na longa duração da história ocidental, a noção conheceu diversos estados, sempre correlatos com tempos fortes de questionamentos da ordem do tempo. $O$ patrimônio é um recurso para o tempo de crise. Se há assim momentos do patrimônio, seria ilusório nos fixarmos sobre uma acepção única do termo." (HARTOG, 2006, p.272)

Com a Revolução Francesa o conceito de patrimônio passa a incluir o entendimento de bem de caráter coletivo, a preservação em reação à perda ou desaparecimento, e a utilização de "patrimônio cultural" como nomenclatura. Inserido no processo de apropriação dos bens do clero e da nobreza passam a ser responsabilidade do Estado. Na França o primeiro patrimônio assim considerado foram as obras de arte. Neste passo, institui-se a questão do valor artístico como critério. Mas, a França revolucionária não poderia guardar monumentos que lembrassem a nobreza e o despotismo. Então, para "ocupar o lazer e embelezar o território de um povo livre", um novo decreto de 1792, da Comissão de monumentos, interessa conservar as obras-primas das artes, e vigiar para que entre as demandas de patriotas e o vandalismo, obras de valor "geral" pudessem salvar as obras ameaçadas. Começa-se a definir, como um domínio único, a área de patrimônio e uma noção moderna de patrimônio com preocupação moral e pedagógica, ou mais ainda, uma noção que se coloca superior às vicissitudes da história, por meio de uma linguagem moralizante, voltada para educação do povo francês. (CHASTEL, 1994, p.60 e 64). Estava em jogo a "gestação de um sentimento patrimonial" entre as disputas dos especialistas e os revolucionários sobre a destruição ou preservação dos monumentos aristocráticos, monárquicos e religiosos.

Para tamanha missão é lançada a determinação de inventariar; identificar; reconhecer e inscrever bens com poder de cultura. Contudo estes bens eram identificados com a noção de monumentos e monumentos históricos, ou seja, bens imóveis.

Os monumentos por sua vez têm ligação direta com a memória (do latim monumentum, derivado de monere, aquele que interpela a memória, (CHOAY, 1999), sua função é rememorar as gerações atuais e futuras fatos, pessoas, rituais entre outros, pelo signo da presença física que faz relembrar o passado e pode contribuir a preservar uma identidade. Monumentos e monumentos históricos passaram a partir do 
século XIX, e permaneceram por longo tempo a denominar as obras de arte, as antiguidades, os bens materiais e outros vestígios do passado que se desejavam conservar e legar às novas gerações, até serem substituídas pela palavra patrimônio.

Importante frisar a ligação da noção de monumento histórico, patrimônio e museus na medida em que, suas naturezas se destinam a identificação e preservação de bens culturais. Se Le Goff pontuou a documentalidade e o caráter de testemunho dos monumentos, na área do patrimônio, toda sua historicização passa pelos monumentos. A noção de monumento é sempre evocada no histórico do patrimônio, sobretudo pelas definições de Alois Riegl de valor e monumento, que acompanharão a atribuição de valores artísticos e históricos aos bens patrimoniais até o presente. A ideia trazida por Riegl na qual todo objeto pode ser convertido em testemunho histórico, com ou sem uma intenção memorialista na sua origem, permanece atual e é a mesma que alimenta a musealia. Segundo Riegl, os monumentos podem ser intencionais, construídos para comemorar e celebrar evento do passado; monumentos históricos, definidos por preferências subjetivas; e monumentos antigos englobando todas as criações do homem ${ }^{5}$. Os monumentos históricos e monumentos antigos comporão, também, portanto, a matéria dos museus, e guardarão funções de memória, preservação e celebração, embora haja uma separação normativa e administrativa entre eles - para os monumentos se destinarão os bens imóveis e para os museus os bens móveis.

Foi ainda no fim do Antigo Regime que a monarquia, sob influência do lluminismo, criou museus e os abriu para um acesso público a suas coleções e acervos. Coleções e acervos confiscados em 1789 pelo governo revolucionário, que ao perigo de sua perda, já que os revolucionários identificavam tais objetos aos seus antigos opressores, criou uma regulamentação para proteção desses bens como de interesse a instrução pública. Uma Comissão de Artes foi criada em 1793 e com ela tais bens passam a valor de documentos da nação e, portanto, a assumir um caráter político. A partir de então o patrimônio passa a fazer parte da construção de uma identidade nacional. E este processo replica-se na formação de todos os Estados Nacionais do Ocidente. Esses bens são de todos, de interesse público, passam a ser salvaguardados sob a tutela do Estado, o que leva a identificação de tais bens ao próprio Estado, a nação Ihes conferindo identidade: protegê-los é proteger um bem da

\footnotetext{
${ }^{5}$ Uma análise sobre a questão do valor em Riegl é apresentada por Maria Cecília Londres Fonseca, em seu capítulo 2, bem como uma longa discussão sobre a noção de valores atribuídos ao patrimônio apresentada em Riegl, Babelon e Chastel, Françoise Choay. FONSECA, Maria Cecília Lourdes. o Patrimônio em processo: trajetória da política federal de preservação no Brasil. Belo Horizonte: Editora UFMG/MinC/IPHAN, 2009.
} 
nação. Eles também passarão a servir a construção da história nacional, sua gênese, uma versão oficial da história que legitima o poder em ação. Ao interesse cultural, se junta e sobrepõem-se os interesses pedagógicos, políticos e ideológicos. A história nacional irá ter peso ainda maior na medida em que tais Estados passem também a metrópoles, e aportarão de suas colônias novos bens para contar a história de seu poder.

Os monumentos serão incluídos nas Convenções de proteção do patrimônio mundial. A Convenção UNESCO de 1972 define os monumentos como patrimônios culturais e naturais, que podem ser monumentos naturais (sítios construídos pelo homem e a natureza, sítios naturais, monumentos naturais formados por formações geológicas), ou construções, obras de arquitetura, esculturas ou pinturas monumentais, e a criação de um órgão para os monumentos (ICOMOS). E para os museus um órgão específico (ICOM) com normas, procedimentos e administrações distintas.

Vê-se assim, das chamadas "Antiguidades" ao seu novo nome (monumentos históricos), um processo de consagração do patrimônio edificado e, a partir de então, a criação de uma jurisdição de proteção e uma política de conservação, restauração, e se bem quisermos, a criação de uma alegoria, como interpretou Françoise Choay (2007).

Atualmente o patrimônio conta com três Convenções outorgadas pelo órgão internacional UNESCO 1972, 2003, 2005. O patrimônio "histórico" foi paulatinamente substituído pela denominação patrimônio "cultural", que comporta todas as formas de patrimônio agora reconhecidas: artístico, arquitetônico, arqueológico, etnológico, documental, industrial, ambiental, geológico, paleontológico, linguístico, genético e os bens imateriais. Novas fronteiras do patrimônio são rompidas por meio da diversidade dos contextos socioculturais, e consequentemente a novas redefinições do conceito de patrimônio que, no presente, trabalha na chave do "Bem Cultural", do "Conjunto Histórico", "Paisagem Histórica Urbana" e dos "Tesouros Vivos" - propostos pela UNESCO, em Recomendação de 2011 e 2003 respectivamente, ou ainda, Lugar de Memória e Sítios de Consciência.

Mais recentemente encontra-se a menção do conceito de "Repertório Patrimonial". De um lado temos o que chamamos de museus tradicionais, herméticos durante muito tempo centrado nas coleções, e que ainda tem força e tradição. De outro, uma proliferação de novas formas de museus, com base em novas noções de patrimônio (a partir de 1950). Estas noções passam a considerar todo objeto ou 
conjunto, material ou imaterial, reconhecido por ser portador do caráter de testemunho, e portador de uma memória histórica individual e coletiva, em qualquer tempo e lugar, que se julga necessário manter ou conservar para transmitir as gerações atuais e seguintes. Processo paralelo às reivindicações e movimentos de inclusão do social na pauta dos museus, no surgimento da Museologia Social e Sociomuseologia, entre o paradigma do museu a serviço das coleções e o paradigma do museu a serviço da sociedade.

Entre o século XX e XXI muito mudou na forma de ver, conceber e organizar um museu. O seu caráter e função também foram repensados, e agora são voltados para uma acepção universalista, em termos de alcance de conteúdo (bens considerados heranças) e de destino (dirigido a toda humanidade) ${ }^{6}$. O fim da Segunda Guerra Mundial aumentou a força da noção universalista e o espírito de preservação na intenção de salvar as obras humanas de caráter excepcional e valor histórico, resultando na criação da UNESCO e seus órgãos específicos de preservação. No Canadá noções de material e imaterial passa a fazer parte das definições de patrimônio em meados de 1950. Mas somente na década de 1960 no contexto dos pós-colonialismo e a defesa dos povos por autorrepresentação o tema dos direitos e, sobretudo, da cultura como um direito passou a pauta do patrimônio e dos museus.

Se hoje os museus se pautam por sua função e utilidade pública e a serviço da sociedade, historicamente, não foi sempre assim. Em todas as funções e épocas, o entendimento de público e o acesso ao saber contido nas coleções migraram, tão e somente, do lugar de devoção às musas ao lugar de devoção de nações, heróis, da ciência; passando por gabinetes privados, da monarquia à burguesia... Mas, e onde esteve o público em tudo isso? E onde está o público agora?

Da defesa do povo apregoada pela Revolução Francesa (e a chegada da réspública), foi somente no pós Segunda Guerra que os termos visitante e comunidade retornaram ao cenário dos museus. Coincidentemente, o mesmo período dos textos do teatro do absurdo. O que faz-nos pensar: teria sido esse um momento em que a Europa,arrasada pelas atrocidades da guerra, retornava ao humano - seja como

\footnotetext{
${ }^{6}$ De acordo com a definição de museus do ICOM, órgão internacional que regimenta o setor desde 1946, em uso e atualizada pelo estatuto da entidade adotado na 210 Conferência Geral em Viena (2007): “Um musée est une institution permanente sans but lucratif au service de la société et de son développement ouverte au public, qui acquiert, conserve, étudie, expose et transmet le patrimoine matériel et immatériel de l'humanité et de son environnement à des fins d'études, d'éducation et de délectation."
} 
essência ou condição de existência, reflexão compilada por Hannah Arendt, publicada em 1958 em seu "A condição humana".

Essa reorganização mundial de blocos, forças e poderio entre nações ideários e ideologias, levou a criação de organizações como o ICOM. Contudo, foram movimentos inovadores e contrapostos à própria instituição ICOM que produziram renovações no âmbito do que hoje chamamos de público. De George Henri Rivière e a experiência precursora do Museu do Homem em Paris, foi somente em 1972 que conceitos realmente novos e inovadores, cujo princípio era criação de museus com a participação e para o público, fizeram-se sentir. Consolidados pela "Mesa- Redonda de Santiago do Chile", e por outras declarações que se seguiram, bem como a criação do movimento intitulado Nova Museologia (Minom, 1984). Mesmo que a Mesa de Santiago tenha sido organizada pelo ICOM, movimento e declarações foram oficializados somente anos mais tarde, assim como a introdução da prática mais "socializante" e interdisciplinar, que tais movimentos trouxeram a museologia. Entre esses conceitos surgiram os ecomuseus, museus comunitários, museus de território, entre outros. A partir de então vemos que a museologia em todo mundo, com ênfase na América Latina, tem em seu ideário, escopo e preocupação o público como destino de seu trabalho.

Voltando nosso olhar para a realidade museal do presente reforça-se a questão: e o público hoje, onde está? Qual sua relação com os museus do agora?

De acordo com dados publicados pelo Cadastro Nacional de Museus (Ibram/Minc, 2010), em 2009 o número do público (em estimativa), que visitou museus em todo Brasil, está acima de 80 milhões de visitantes ${ }^{7}$. Um número expressivo que segundo o estudo aumenta consideravelmente a cada ano. Muitos fatores devem ser considerados neste dado como distribuição de museus e públicos por regiões do país por exemplo. Entretanto, percebe-se que os dados das instituições recaem com frequência sobre o de números de visitantes entre outras cifras. A grande questão que fica é: esses museus conhecem o público que os visita?

Esse conhecimento só poderá ser construído por meio de pesquisa especialmente dedicada ao entendimento desse público, por meio de avaliações e estudos de recepção. No Brasil, há profissionais que se dedicam a esse tema, mas poucas instituições empregam esse tipo de trabalho em suas rotinas. O Cadastro Nacional de Museus informa ainda que maioria $74,7 \%$ entre os museus cadastrados

\footnotetext{
${ }^{7}$ Instituto Brasileiro de Museus. Museus em Números/Instituto Brasileiro de Museus. Brasília: Instituto Brasileiro de Museus, 2011. p. 93-96; vol. 1.
} 
declarou realizar esse tipo de estudo, quanto à periodicidade dos mesmos, o número cai para $53,5 \%{ }^{8}$.

Fato é que ainda não se conhece quem é o publico que visita museus. Pouco se sabe sobre a maioria deles. Ou pouco se avalia sobre o quanto as instituições museais de caráter e financiamento público, são realmente abertas, e são realmente eficazes em transmitir os patrimônios da humanidade à sociedade e ao seu desenvolvimento?

Certo, por hora, é que a comunicação é a forma de chegar ao público. Não mais apenas transmitindo uma mensagem (bem ao tom dos museus transmissores de conhecimento do século XIX e o domínio dos meios de transmissão como apregoou a escola frankfurtiana), mas mediando o contato entre público e patrimônio, ao ponto de propiciar experiência e interação, e finalmente ao uso social do museu.

Os museus são vistos como repositórios de memória. Esta memória, como já vem sendo largamente ilustrado, apresenta-se nos mesmos moldes dos museus e narrativas apresentadas no século XIX. Seus conteúdos, formato e discursos proporcionam mais distância que reconhecimento. Eles uniformizam diferenças, e não respondem a ambivalência da sociedade, que sabe questionar, mas deixa-se dominar ao mesmo tempo pelos ditames da sociedade de consumo.

Se a criação do museu é engenharia europeia sua transposição para as colônias, mesmo que em processo de independência, seguiu o mesmo modelo. $E$ mesmo no século XX, no Brasil, observa-se que o discurso do patrimônio em geral tomou ditames nacionalistas e centralizadores - a nação pensada na totalidade sem considerar suas vastas diferenças (GONÇALVES, 1996). Sempre pautado pelo discurso da negação, ou do que estava prestes a ser perdido - "retórica da perda"- a política patrimonial brasileira surge sem a ideia de identificar e preservar o que somos como principio. Sua missão era salvar o que estava em risco de disparição. Monumentos, obras de arte e edificações históricas eram o alvo da atenção, em iniciativas que tiveram início na década de 1920 por parte da elite intelectual brasileira: "O patrimônio da nação era apresentado sob os efeitos de um processo de desaparecimento, dispersão e destruição (Rodrigo 1952:11-60)"9.

\footnotetext{
8 Idem.

${ }^{9}$ GONÇALVES, José Reginaldo Santos. A retórica da perda: os discursos do patrimônio cultural no Brasil. Rio de Janeiro: Editora UFRJ; IPHAN, 1996. p.90.
} 
Os desafios são enormes. A tarefa de dialogar com os processos históricos contemporâneos esbarra no imobilismo das coleções, na necessidade de intersecção profissional, e uma extensa herança onde o museu serviu - e foi criado - como campo de afirmação ideológica, identitária, universalizante e pedagógica.

O museu é sempre um lugar de representação de questões políticas e identidades movidas por disputas e conflitos. Nesse âmbito, a memória também passou a ser subjetiva pautada nas micro-histórias e na história dos oprimidos. Prova disso é o grande alcance e utilização que a história oral vem apresentando na área patrimonial em especial. Histórias de vida, dos bairros, de movimentos podem agora encontrar mais espaços em iniciativas de preservação.

Vivemos em contextos onde minorias reivindicam espaço de atuação e reconhecimento. Não interessa mais a história coletiva. Isso ocorre em todos os campos e também na área patrimonial, onde grupos desejam ver-se representados nos museus. Um campo particular dessa tendência é o exercício que o patrimônio cultural imaterial tem encontrado no Brasil.

Desde a promulgação legal dos marcos que instituem os bens intangíveis como bens dotados de preservação, assistimos a uma proliferação dos motes e modos de salvaguardar essa categoria de patrimônio. As ações estão, sobretudo, guiadas pelos documentos e ações regulatórias em plano nacional (Iphan) e internacional (Unesco). Uma questão que se tornará cada vez mais presente é a relação deste tipo de bem cultural com as instituições museais. Museus e Museologia, assim como a História e demais áreas, passaram a repensar práticas e políticas também em torno do imaterial, que vem sendo cada vez mais tratado pelos museus e pela museologia.

Mas o passado está ou continua na moda. O retrô, a marca de originalidade interposta nos anúncios “desde 18..", as reconstituições de época em casas comercias por meio de fotografias antigas, ou mesmo na televisão e cinema, mostram o fluxo de um outro movimento, de uma sociedade que tudo quer guardar ${ }^{10}$. O Presentismo estaria nos convidando a uma mudança de nosso regime de historicidade?

"O que significou, do ponto de vista do tempo, de sua ordem, o movimento de extensão e de universalização do patrimônio, ao qual nós temos assistido há um bom quarto de século? De qual regime de historicidade a patrimonialização galopante dos anos 1990, como nós a qualificamos algumas vezes, pode ser a marca? Este gosto pelo passado vinha testemunhar

\footnotetext{
${ }^{10}$ Em boa síntese vale replicar a fala de Andreas Huyssen: "Trocando em miúdos, o passado está vendendo mais do que o futuro. Mas por quanto tempo ninguém sabe." (Huyssen, 2000, p. 24)
} 
repentinamente um tipo de nostalgia por um antigo regime de historicidade, contudo, desde há muito fora de uso? Inversamente, como ele podia ainda se ajustar a um regime moderno, que tinha posto, há dois séculos, todo seu "fervor de esperança" no futuro?

(...)

Nesta nova configuração, o patrimônio se encontra ligado ao território e à memória, que operam um e outro como vetores da identidade: a palavra chave dos anos 1980. Mas, trata-se menos de uma identidade evidente e segura dela mesma do que de uma identidade que se confessa inquieta, arriscando-se de se apagar ou já amplamente esquecida, obliterada, reprimida: de uma identidade em busca dela mesma, a exumar, a "bricoler", e mesmo a inventar. Nesta acepção, o patrimônio define menos o que se possui, o que se tem e se circunscreve mais ao que somos, sem sabê-lo, ou mesmo sem ter podido saber. $O$ patrimônio se apresenta então como um convite à anamnese coletiva. Ao "dever" da memória, com a sua recente tradução pública, o remorso, se teria acrescentado alguma coisa como a "ardente obrigação" do patrimônio, com suas exigências de conservação, de reabilitação e de comemoração." (HARTOG, 2006, p. 265 e 266).

Esse movimento não é novo e se repete em todo momento de ruptura. A própria definição de Ocidente acontece com uma cisão em relação ao outro (a exemplo do Orientalismo de Edward Said), ou da definição de modernidade, e de seu papel na definição do ocidental. Ideias essas que invadiram a critica de arte, ela mesma traçada por rupturas de conceitos, escolas, estilos, etc. Uma historicidade fundamentada na linearidade, evolução sucessiva de quadros, onde o presente é mera marca divisória entre o passado e o futuro. Modernidade baseada também em identidade. A historicidade divide espaço com a etnicidade: uma identidade étnica, nacional e/ou regional. Todas elas trabalhadas no presentismo e na experiência do tempo, como bem elucidam François Hartog ou Claude Lévi-Strauss ${ }^{11}$, traz o passado sempre apresentado em função do presente. Se daí nasce um relativismo em relação a todos os valores e ao próprio futuro, vivemos também uma onipresença da noção de memória e de sua supervalorização

\footnotetext{
${ }^{11}$ A referência está em Lévi Strauss, no livro Raça e Cultura, texto escrito no contexto do pós-guerra, da criação da UNESCO e subsequente discussão da diversidade cultural. A UNESCO encomendou a LéviStrauss um discurso sobre o racismo, onde ele conclui: o racismo só existe e encontra espaço pelo etnocentrismo.
} 


\title{
1.2 - Estado da Arte: o Patrimônio Imaterial dentro e fora dos
} museus

\begin{abstract}
"O património imaterial tem uma complexidade distinta do património material. Neste nós temos a dimensão tangível dos objectos que manuseamos, expomos, colocamos nas reservas, restauramos... O património imaterial tem uma dimensão intangível que se transmite na vida comunitária, nas relações com as pessoas e se manifesta nos conhecimentos, nas artes e nas festividades. Como é que o museu pode representar e gerir esta realidade?
\end{abstract}

A gestão museológica do património imaterial passa por uma intensa e empenhada relação com as pessoas da comunidade, detentoras de saberes e produtoras da sua própria cultura. $O$ museu assume-se assim como um espaço de exibição, explicação e também de afirmação do património imaterial." (MARTINS, 2013) $^{12}$

A primeira menção ao patrimônio imaterial está no projeto de criação do Serviço do Patrimônio Artístico Nacional - Sphan - atual Iphan via Anteprojeto para a criação do Serviço do Patrimônio Artístico Nacional, elaborado por Mario de Andrade, a pedido do então Ministro Gustavo Capanema.O imaterial e as manifestações populares foram sobrepujadas pelo ideário de "pedra e cal" que dominou a política do principal órgão de preservação do Brasil. O popular e a imaterialidade da cultura foi retomado somente na direção Aloísio Magalhães deste órgão (1970/1980), que junto com outros intelectuais conseguiu criar um instituto de pesquisa e referenciação da cultura brasileira, mesmo em período de ditadura civil-militar. A cultura era para Aloísio mola propulsora de desenvolvimento. Com sua morte os projetos por ele encabeçados não tem a continuidade. Ainda que a Constituição Federal Brasileira de 1988, artigo 216, institui "bens de natureza material e imaterial ao conjunto do patrimônio cultural brasileiro".

Assim, vemos que esta riqueza cultural já foi identificada e relacionada ao patrimônio cultural há muitas décadas, nas figuras principais de Mário de Andrade e Aloísio Magalhães. Eles deixaram claro que a identidade, o desenvolvimento e a rica diversidade cultural do Brasil estavam contidos na chamada cultura popular, e somente ela, é a verdadeira expressão da cultura brasileira. As ações pioneiras

\footnotetext{
${ }^{12}$ Rui Sousa Martins em entrevista realizada no Museu de Vila Franca do Campo (S. Miguel, Açores), em 6 de Agosto de 2013 por Ana Carvalho. Disponível em http://nomundodosmuseus.hypotheses.org/5882
} 
serviram de modelo aos instrumentos de valorização da cultura popular e tradicional das populações brasileiras ${ }^{13}$. Afinal, o conteúdo e a natureza do bem intangível sempre existiram: saberes, nos ofícios, nas festas, nos rituais, nas expressões artísticas e lúdicas, produzidas e vivenciadas pela tradição de indivíduos ou grupos, como expressão de sua identidade cultural e social, reconhecida como tal por esses próprios grupos (Iphan, 2000; UNESCO, 2003).

Concretamente, esse ideário foi expresso na primeira menção ao patrimônio imaterial, contida no projeto de criação do Serviço do Patrimônio Artístico Nacional ${ }^{14}$ Sphan - atual Iphan. Mas é somente com a chegada de Aloísio Magalhães à direção do órgão (anos 1970-1980) que o intangível passa a ser estudado e reconhecido. Finalmente em 1997, a Carta de Fortaleza, lançou as bases legais para que se reconhecesse aquele tipo de patrimônio, no que se convencionou chamar de

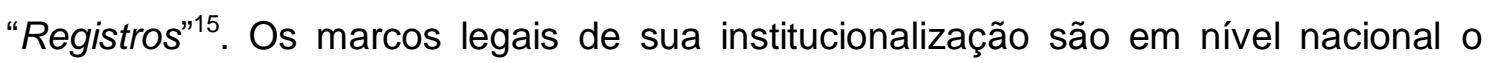
artigo 216 da Constituição Federal Brasileira de 1988, instituindo "bens de natureza material e imaterial ao conjunto do patrimônio cultural brasileiro" ${ }^{16}$; o Decreto nํ 3.551 , de 04/08/2000, relacionado ao "Registro de Bens Culturais de Natureza Imaterial que constituem o patrimônio cultural brasileiro", complementado pela Resolução $n^{\circ} 1$, de 03/08/2006 do Instituto do Patrimônio Histórico e Artístico Nacional - Iphan, e em nível internacional a Convenção Unesco de $2003^{17}$.

Na América Latina, o ICOFOM LAM realizou por certo período, encontros anuais sequenciais, referendando documentos nos temas mais atuais da museologia:

\footnotetext{
${ }^{13}$ Fala-se aqui das premissas contidas na criação do Sphan, da Missão de Pesquisas Folclóricas (1938) idealizada e organizada por Mario de Andrade a frente do Departamento de Cultura de São Paulo, sem outra realização equivalente ainda hoje, do Instituto Nacional do Folclore, da Campanha Nacional do Folclore, o CNRC e a instrumentalização de registro de referências culturais desempenhadas por Aloisio Magalhães. Além das inúmeras referências com escritos de Mário de Andrade sobre o tema, evoca-se o texto Bens Culturais: Instrumento para um Desenvolvimento Harmonioso. Aloisio Magalhães. Revista do Patrimônio, n.20, 1984, p.40-44. E, na mesma edição: Política de Preservação e Democracia. Joaquim Falcão, p. 45.

${ }^{14}$ Anteprojeto para a criação do Serviço do Patrimônio Artístico Nacional. Revista do IPHAN, n. 30, p. 270-287, 2002. Elaborado por Mario de Andrade, a pedido do então Ministro Gustavo Capanema.

${ }^{15}$ Em março de 1998, foram criados o Conselho Consultivo do Patrimônio Cultural e Grupo de Trabalho Patrimônio Imaterial (GTPI) para elaborar propostas de regulação da preservação de bens imateriais. A proposta levou ao Decreto 3.551 do ano 2000, implantando o Registro de Bens Culturais de Natureza Imaterial (através do Inventário Nacional de Referências Culturais (INRC), e o Programa Nacional do Patrimônio Imaterial. Em 2004, o Ministério da Cultura, via Decreto $n^{\circ} 5.040$, criou o Departamento do Patrimônio Imaterial do Iphan (DPI), ao qual se subordinou o Centro Nacional de Folclore e Cultura Popular (CNFCP), em funcionamento desde 1958. Os Sambas, as Rodas, os Bumbas, os Meus e os Bois. A Trajetória da Salvaguarda do Patrimônio Cultural Imaterial no Brasil. Iphan. Brasília: Brasília Artes Gráficas, maio de 2006.

${ }^{16}$ Os sambas, as rodas, os bumbas, os meus e os bois: a trajetória da salvaguarda do patrimônio cultural imaterial no Brasil. Iphan. Brasília: Brasília Artes Gráficas, maio de 2006.

${ }^{17}$ Convenção para a salvaguarda do patrimônio cultural imaterial (UNESCO,2003).
} 
Carta de Fortaleza novembro de 1997 - Fortaleza, 14 de novembro de 1997; Carta de Cuenca 1997 - Cuenca, Ecuador, dezembro de 1997;Declaração de Xochimilco 1998 - Xochimilco, México, junho de 1998; Carta de Coro 1999- Coro, Venezuela, 4 de dezembro de 1999; Declaração de Santa Cruz 2000- Santa Cruz, Río de Janeiro, maio de 2000; Carta de Montevidéu 2001 -Montevidéu, Uruguai, 14 de dezembro de 2001.

Em geral elas ratificam referendos antecessores reafirmando sua vigência e recomendações, a começar pela Mesa Redonda de Santiago de Chile (1972), seguido pela Declaração de Caracas (1992); Conclusões dos Encontros Regionais do ICOFOM LAM (1992/1996); a Carta de Cuenca (1997); a Declaração de Xochimilco (1998), a Carta de Coro (1999), e a Carta e Manifesto de Santa Cruz (2000).

Na museologia, para entendimento do contexto do imaterial nos museus há que se retomar a herança construída pelas inovações de algumas Cartas Patrimoniais. Em particular destaca-se a "Mesa-Redonda de Santiago do Chile", organizada pelo ICOM $^{18}$, que consolida em 1972 o movimento da Nova Museologia. Portugal, Canadá e França são os principais terrenos de seu desenvolvimento. Dois expoentes do movimento, muito conhecidos no Brasil são Hugues de Varine-Bohan e George Henri Rivière $^{19}$. A oficialização das Declarações e do Minom pelo ICOM, introduziram uma prática mais "socializante" e interdisciplinar à Museologia ${ }^{20}$. Aliás, pensar a museologia contemporaneamente, requer uma contínua revisão dos seus atos e documentos constitutivos (encontros, estatutos, comitês) ${ }^{21}$.

\footnotetext{
${ }^{18}$ Ratificada pela Declaração de Quebec (1984), com seus "Princípios de Base de uma Nova Museologia”, onde "afirma a função social do museu e o caráter global das suas intervenções", e cria os Ecomuseus e Museus comunitários. DECLARAÇÃO de Quebec. In: ATELIER INTERNACIONAL ECOMUSEUS/ NOVA MUSEOLOGIA. Canadá,Out.1984. Em 1985 é criado Movimento Internacional para uma Nova Museologia (MINOM), organização reconhecida e afiliada ao Conselho Internacional de Museus (ICOM).

${ }^{19}$ Suely Cerávolofa um longo apanhado sobre o tema, 2004, p. 259-261. In: CERÁvOLO, Suely Moraes. Delineamentos para uma teoria da Museologia. Anais do Museu Paulista, v. 12, n.12. São Paulo: Universidade de São Paulo, 2004. p. 327-268.

20 Entre as obras de referência sobre a Nova Museologia estão: RIVIERE, Georges Henri. Définition évolutive de l'écomusée. Ecomusée informations de la Communauté Le Creusot Montceaules Mines, Le Creusot, n.8, p.l, déc. 1983; VARINE-BOHAN, Hugues de.L'écomusée: au de là du mot. Museumm; 148, XXXVII (4), p. 185, 1985; DESVALLÉES, André. Vagues: une anthologie de la nouvelle museologie. Paris: W M. N. E. S., 1992. Vol. 1; HUBERT, François. Les écomusées en France: contradictions et déviations. Museum, Paris, n.148, p.186-190, 1985. BARBUY, Heloisa. A conformação dos ecomuseus: elementos para compreensão e análise. Anais do Museu Pauista, 1995, vol.3, n.1, pp. 209-236.

${ }^{21}$ CERÁVOLO, Suely Moraes. Delineamentos para uma teoria da Museologia. Anais do Museu Paulista, v. 12, n.12. São Paulo: Universidade de São Paulo, 2004. p. 327-268. Também em: PRIMO, Judite. Museologia e Patrimônio: Documentos Fundamentais - Organização e Apresentação. Cadernos de Sociomuseologia/ no 15, Págs.189-191; ULHT, 1999; Lisboa, Portugal, e Judite Santos Primo. Pensar Contemporaneamente a Museologia.Cadernos de Sociomuseologia: Museologia: Teoria e Prática. ULHT Universidade Lusófona de Humanidades e Tecnologias, n 16, 1999.
} 
O tema do imaterial também tem sua contribuição na museologia brasileira por museólogos que participam dos debates do ICOM, ao mesmo tempo afinados com as novas tendências. Haja vista a grande adesão que a Nova Museologia conheceu no Brasil.

Em 1989, a museóloga Waldisa Rússio Guarnieri introduz o tema identidade cultural na Museologia, retomando a delimitação conceitual sobre bens culturais reconhecidos como "elementos perpétuos" ${ }^{22}$ : as paisagens físicas e naturais, o urbano, a criação material humana, a criação imaterial humana. Guarnieri, sintonizada com os novos desafios e com a museologia social, defende a existência de testemunhos materiais diretos e indiretos, mas também, os testemunhos imateriais.

Pensar a inserção do imaterial no plano dos museus significa adentrar, novamente, em seus paradigmas e desafios tais como "museus sem acervo", "museus e novas tecnologias", "museus interativos", "museus de rua", "crise dos museus" ou "museus em um mundo em crise", etc ${ }^{23}$. Ou, simplesmente, retornar a uma questão inerente a natureza de todos os museus: preservar o quê, para quê, para quem? Questões defendidas pela Museologia Social e Nova Museologia, basicamente o alargamento da noção de patrimônio com a redefinição do objeto museológico, a interdisciplinaridade e a participação comunitária ${ }^{24}$. Vale destacar que é sempre necessário ter clara a distinção entre museu e musealização em qualquer um dos caminhos ou nomenclaturas adotadas, pois um processo de musealização é sempre mais amplo. A musealização pode ocorrer dentro ou fora de um espaço institucionalizado, e consiste em tratar e trabalhar algo selecionado e considerado relevante, colocando em destaque o que ele contém em valores, saberes, conhecimento, por conseguinte apresentado e preservado para o maior número de pessoas possível.

Em 2001 o ICOFOM LAM realizou um encontro especialmente dedicado a museologia e patrimônio imaterial. Considerando a América Latina um campo privilegiado por sua diversidade cultural e o encontro entre povos, a identidade, a memória coletiva, a oralidade estão apontados como matéria do patrimônio imaterial

\footnotetext{
${ }^{22}$ Bens "(...) que permanecem nesse processo contínuo de "criação, transmissão e reformulação", no qual os homens "produzem e utilizam bens culturais". WaldisaR. Guarnieri, Museologia e Identidade. In: BRUNO, M. C. O. (Coord.). O ICOM-Brasil e o pensamento museológico brasileiro: documentos selecionados. São Paulo: Pinacoteca do Estado, 2010. v.1, partes 1 e 2, p. 182.

${ }^{23}$ Temas em pauta nas reflexões dos profissionais de museologia há décadas. Mário CHAGAS. No museu com a turma do Charlie Brown, 1994 e Novos rumos da Museologia. Museália,1996.

${ }^{24}$ Mário MOUTINHO. Sobre o conceito de museologia social.p.6. In: MOUTINHO,Mário.Sobre o conceito de Museologia Social. In: Cadernos de Museologia. Lisboa: Centros de Estudos de Sóciomuseologia.ISMAG-U.L.H.T.v.1.1993
} 
no território latino em todos os documentos produzidos no Encontro. E ainda, que o imaterial tem um poder suplementar de comunicação, pois fala diretamente com a realidade cotidiana do público, e que muitos museus - sejam de antropologia ou outros - têm realizado muitas exposições tendo por base o patrimônio imaterial.

\section{Os museus entram como nessa nova configuração?}

Na direção desta tendência muitas formas de explorar e abordar o imaterial são possíveis e praticadas pelos museus. Dentro do contexto do inventário do patrimônio imaterial suíço foi realizada a exposição "Hors-Champs", que evidencia estas múltiplas formas. Trata-se de um ótimo exemplo, seja no leque de temas e assuntos que podem ser co-relacionados, quanto na aplicação museal e expográfica de um saber cultural voltados a mediação e interação com o público.

Desenvolvida pela equipe do Museu de Neuenburg (MEN), com o Instituto de Etnologia da Universidade de Neuchâtel e outros parceiros (Universidade de Bâle e Lausanne, e Centro de Dialetologia da Universidade de Neuchâtel), foi criada pelo projeto Midas'sTouch, iniciado em 2009. Faz parte das atividades de ratificação da adesão suíça a carta da Unesco relativa a proteção do Patrimônio Cultural Imaterial $(\mathrm{PCl})$. Entre as atividades de inventário e seleção do patrimônio imaterial suíço, o projeto passou por várias etapas que envolveram outras duas exposições intermediárias e muitos experimentos até a chegar à concretização da exposição e resultado final intitulada "Hors-Champs". Desde o primeiro resultado - a exposição Bruit, uma larga pesquisa dos sons, do fenômeno sonoro e da história da etnomusicologia - os pesquisadores viram que levantar os elementos do $\mathrm{PCl}$ suíço equivalia a um processo de musealização, e que em termos de patrimônio, os limites entre material e imaterial eram sempre difíceis de separar e se justificar. A exposição apresentada na segunda etapa apresentou o patrimônio cultural imaterial através das imagens e da antropologia contando sobre a coleta etnográfica de objetos, refletindo sobre aqueles objetos e tradições que nunca chegam às listas de classificação patrimonial ou são mostrados nos museus. Para tanto foi realizada uma analogia com o cinema, e aos frames que mesmo filmados não são mostrados na versão final de um filme. Por fim, o resultado de Hors-Champs foi definido em três níveis: uma abordagem comparativa ligada a história dos museus, a exploração do universo digital, virtual e das novas tecnologias, e uma abordagem crítica e poética sobre as fronteiras entre arte e etnografia. Sempre com caráter lúdico, destaca-se em especial o primeiro nível cujos elementos mostravam a seleção "patrimonial" de objetos e pessoas, evocação 
do que não está presente, a estetização de objetos comuns da atividade humana, rememorar pessoas e eventos, imitar realidades e provocar associações de ideias. Estes itens correspondem a eixos temáticos trabalhados pela equipe a partir da análise de seis domínios de utilização de imagens em antropologia, em associação a prática museal e de patrimonialização do imaterial. Este trabalho comparativo gerou seis denominações trabalhadas de formas diferentes na exposição. São elas: a "obsessão da seleção/classificação"; o desejo de reproduzir o gesto; o desejo de estetizar a realidade; o desejo de imitar a realidade com a maior fidelidade possível; o desejo de conservar a memória; e o desejo de superar a memória criando choques interpretativos. A título de exemplo, um dos módulos da exposição apresentava ao público uma cenografia com reproduções de pequenas casas da Groeenlândia reproduzidas em três dimensões, a partir de fotografias do etnólogo Philippe Geslin. A representação era composta ainda pela reprodução de janelas de um mapa virtual ao estilo Google Earth, que dispunham provocações para interação do público. A intenção era dar a impressão de uma renovação das práticas museais/expográficas e um acesso facilitado ao conhecimento.

No roteiro internacional, seguindo as recomendações da UNESCO, os países implantam programas mundiais inscrevendo suas manifestações para alçar o titulo de patrimônio da humanidade como no caso do programa TESOUROS VIVOS, mas também para manifestações particulares onde a cultura oriental ganha terreno.

A Escócia também é um grande exemplo de como o imaterial perpassa uma cultura e é introjetado nos museus, favorecidos pelo forte sentimento de reconhecimento e identidade desta população. Em termos museológicos e de políticas públicas, os escoceses são um excelente estudo de caso pela sistematização de dados e compilação de indicadores culturais que vêm produzindo. A Escócia possui 400 museus e galerias presentes em todo país e em todas as suas comunidades. Eles constituem uma parte muito importante da economia agregando um bilhão de libras e mais de 23 milhões de visitantes por ano, empregam 3000 pessoas e possuem o mesmo número em voluntariado engajado no setor. Verifica-se um elemento diferencial nos museus escoceses presente no reconhecimento e valorização incondicional das tradições e dos patrimônios locais pela população escocesa, assim como, uma ativa participação nos museus e em atividades por eles propostas. Composto em maioria por museus comunitários e geridos pelas comunidades, as heranças intangíveis aportam sentido de identidade aos escoceses. Este forte senso de identidade envolve a preservação de canções, superstições e tradições. Do lado gerencial e de governo, existe uma política sistemática de suporte, promoção, 
avaliação de índices de público e, sobretudo, um programa de criação de valores por meio dos museus, tendo isto como visão de investimento no setor, intitulada por "The National Strategy for Scothand's Museums and Galleries". Tudo isto é desenvolvido por uma coleta de dados de performance, indicadores ("Key performance indicator") para criação de uma metodologia de desenvolvimento dos museus, bem como a padronização de seus processos e normas.

\section{3 - O imaterial ou intangível: a construção de um conceito}

A corrente museológica que define de modo mais claro uma aproximação ou inclusão dos bens imateriais é a museologia como estudo da relação específica entre homem e realidade ${ }^{25}$. Dentro desta corrente, a museóloga Waldisa Rússio Guarnieri, retoma a delimitação conceitual sobre bens culturais reconhecidos como "elementos perpétuos"26: as paisagens físicas e naturais, o urbano, a criação material humana, a criação imaterial humana. Guarnieri, sintonizada com os novos desafios e com a museologia social, defende a existência de testemunhos materiais diretos e indiretos, mas também, os testemunhos imateriais. Como ela afirma:

"Até este momento ocupamo-nos do objeto - realidade objetiva e externa ao homem (ob+jectum) - enquanto fonte material de informação.

Mas para que servem os outros objetos, realidade objetivas e externas ao homem e que não são substâncias materiais? Podese apontar, por exemplo: o modo de sentir, de pensar, de agir, que se traduzem em linguagem gestual, oral, linguagem de

\footnotetext{
${ }^{25}$ Stransky (anos1970 e 1980) e Anna Gregorová são os principais autores que definem essa nova acepção de museologia, e que exerceriam larga influência nos museólogos à partir de sua publicação. Os dois autores não estão totalmente de acordo em suas definições de relação entre homem e realidade. Contudo, a premissa propiciou uma corrente de museólogos adeptos desta teorização: Wojciech Gluzinsk, Waldisa Rússio e através desta uma torrente de museólogos brasileiros. A partir dela Gluzinsk formulou o que chama de Museologia Postulada: representação de atividades do museu voltadas a transmissão de valores simbólicos incorporados aos objetos (MENSCH,1994.). E Waldisa postulou o fato museal ou museológico: a relação entre homem e objeto em um cenário institucionalizado, ou "a relação profunda entre o homem, sujeito que conhece, e o objeto, parte de uma realidade da qual o homem também participa, e sobre a qual tem poder de agir" (GUARNIERI, 1989). Outra importante definição conceitual é a Patrimoniologia de Tomislav Sola(1992), que inclui a relação com o termo herança, e não apenas com o museu. MENSCH, Peter Van. O Objeto de estudo da Museologia. Rio de Janeiro: UNIRIO/UFG, 1994.

${ }^{26}$ Bens "(...) que permanecem nesse processo contínuo de "criação, transmissão e reformulação", no qual os homens "produzem e utilizam bens culturais". Waldisa R. Guarnieri, Museologia e Identidade, 1989. In: BRUNO, M. C. O. (Coord.). O ICOM-Brasil e o pensamento museológico brasileiro: documentos selecionados. São Paulo: Pinacoteca do Estado, 2010. v.1, partes 1 e 2, p. 182.
} 
brincadeiras, de caretas... E a extensa e profunda gama de valores afetivos?

É preciso lembrar que com respeito aos modos de produção e às relações sociais, para apontar somente alguns exemplos mais flagrantes, há testemunhos materiais diretos e testemunhos materiais indiretos, mas há, também, testemunhos imateriais enquanto objetos.

O que salta aos olhos é que a Museologia atual não pode simplesmente e de um momento para o outro, descartar o fato museológico no qual a relação homem/objeto apresenta, como objeto, o complexo das relações e dos relacionamentos humanos e sociais, sobretudo porque esse complexo está inserido entre as mais frequentes $e$ as mais profundas preocupações do homem de nosso século.

Evidentemente, a musealização de tais objetos complexos exige novas técnicas, novos métodos, novos tipos de cenários museais, quer dizer, uma nova tipologia museológica e, também, um museólogo que seja um cientista mais completo e um trabalhador social mais atuante."27

O museu outrora de coleções, passa a uma museologia das relações sociais e de todas as formas de interação do homem com o meio físico ${ }^{28}$. As obras-primas dão lugar aos objetos testemunho, uma nova noção apoiada pelos museus de etnografia e antropologia, o local do fenômeno museológico dá-se a céu aberto, nos territórios, em suma, tudo passa a ser musealizável: práticas culturais e modos de vidas das sociedades, recursos e paisagens naturais, saberes e tradições comunitárias. É uma concepção que se abre a multiculturalidade, a minorias e suas identidades, e a democratização. Alarga-se o fato museal. Diferentes perspectivas de gestão da musealização dos processos patrimoniais são praticadas no presente. Uma museologia social encontra lugar no movimento da Nova Museologia, consolidados em 1972, na "Mesa-Redonda de Santiago do Chile", e posteriormente pela Sociomuseologia. ${ }^{29}$

\footnotetext{
${ }^{27} \mathrm{O}$ ICOM-Brasil e o pensamento museológico brasileiro: documentos selecionados. São Paulo: Pinacoteca do Estado, 2010. v.1, partes 1 e 2, p. 182.

${ }^{28}$ As novas diretivas encontram terreno no nascimento da museologia teórica e de seu comitê especializado em 1977, denominado Icofom, no seio do ICOM, de onde surge o desenvolvimento de novas formas de pensamento e olhar museológico. O segundo grande momento pode ser dado por documentos internacionais cujo grande marco é Santiago do Chile para formalização do museu integral e da museologia social propriamente dita. Waldisa Rússio, Hugues de Varine e Ulpiano B. de Menezes são contemporâneos de tais transformações, a que permearam todo seu pensamento. Cerávolo, Suely Moraes. Delineamentos para uma teoria da Museologia. Anais Museu Paulista, Dez 2004, vol.12, no.1, p.237-268. ISSN 0101-4714

${ }^{29}$ Ratificada pela Declaração de Quebec (1984), com seus "Princípios de Base de uma Nova Museologia", onde "afirma a função social do museu e o caráter global das suas intervenções", e cria os Ecomuseus e Museus comunitários. DECLARAÇÃO de Quebec. In: ATELIER INTERNACIONAL ECOMUSEUS/ NOVA MUSEOLOGIA. Canadá,Out.1984. Em 1985 é criado Movimento Internacional para uma Nova
} 
Sobre a musealização de bens culturais intangíveis, pois, como também afirmou Waldisa: "O que se pergunta, agora, é se esses objetos "imateriais"; que representam aspectos significativos da identidade são ou não "musealizáveis". Enquanto "realidade objetiva", enquanto parte da realidade da qual o homem também participa, devem esses objetos permanecer potencialmente museológicos?"30

Museus compostos por objetos: objetos-testemunhos, objeto símbolo, semióforos, musealia, são signos, linguagem, suportes de práticas sociais. Os museus formados a partir de temas e não de coleções têm criado novas formas de materializar e musealizar a cultura. A primeira é continuar sim utilizando-se de objetos relacionados ao tema ou bem musealizado de modo a representá-lo. Na maioria dos casos, com ou sem objetos, a exposição (museológica) é a forma principal de apresentação, e que materializa o imaterial. Outras formas relacionam-se a criação de contextos de representação como a criação de suportes visuais, bases de dados referenciais, jogos e outras plataformas interativas. Mas há uma delas, mais diretamente ligada a coleta que desejo me debruçar, pois mais que um instrumental ou ferramenta, ela constitui o processo de musealização, o alimenta e cria, neste processo, um acervo. Trata-se da utilização da oralidade de diversas formas e com diferentes objetivos, e que forma neste caso um acervo de testemunhos orais. Objetos testemunho são os próprios testemunhos fornecidos por indivíduos sendo eles as testemunhas oculares ou detentores de um saber específico ${ }^{31}$.

O imaterial sempre esteve presente nos museus e suas coleções, bem como são matéria de seu trabalho. Inexorável é, em verdade, a busca do imaterial quando somente o material é testemunho. Mesmo quando a ancestralidade é provada e estudada por meios científicos, ainda permanece em aberto a interpretação do objeto, os reais usos e significados que o objeto teve em seu contexto original. Através dos

Museologia (MINOM),organização reconhecida e afiliada ao Conselho Internacional de Museus (ICOM). Sobre a museologia social: MOUTINHO, Mario Canova. Sobre o Conceito de Museologia Social. Cadernos de Museologia. ULHT: Lisboa, 1993.

${ }^{30}$ Waldisa R. Guarnieri, Museologia e Identidade. In: BRUNO, M. C. O. (Coord.). O ICOM-Brasil e o pensamento museológico brasileiro: documentos selecionados. São Paulo: Pinacoteca do Estado, 2010. v.1, partes 1 e 2 , p. 182.

${ }^{31}$ Objetos-testemunho: termo utilizado por Jean Gabus (1965) e Georges Henri Rivière(1989). Objeto símbolo:expressão utilizada por Georges Henri Rivière para nomear objetos-testemunho sintetizadores de uma cultura ou época. Semióforos: termo de Krzysztof Pomian são objetos descontextualizados, mas com carga simbólica e "portadores de significados", ganham um novo valor e significado no museu. Musealia significa objeto de museu, considerado autentico que testemunha e revelam desenvolvimento da sociedade e natureza segundo Schreiner (1985). Trata-se de um neologismo, pouco utilizado. Conceitos-chave de Museologia/André Desvallées e François Mairesse, editores; Bruno Brulon Soares e Marília Xavier Cury, tradução e comentários. São Paulo: Comitê Brasileiro do Conselho Internacional de Museus: Pinacoteca do Estado de São Paulo: Secretaria de Estado da Cultura, 2013. p.68-72. 
tempos tradições se mantiveram e se perderam. Tradições foram reinventadas ou simplesmente novas tradições foram inventadas.

O imaterial como entendido hoje traz a vantagem do contemporâneo. O teor do patrimônio imaterial está na matéria viva da vida em curso: sua existência presente, seus agentes presentes e atuantes, a prática em curso de acontecer e repetir no cotidiano. Este caráter de um lado presentificado, de outro, enraizado nas práticas em curso aproxima o patrimônio imaterial de maneira privilegiada do modus operandis da antropologia.

O imaterial tem em sua natureza um patrimônio construído sobre e sob um espaço, que pode ser geográfico e/ou uma construção social, daí casar perfeitamente com o conceito de territorialidade, cada vez mais utilizado para relacionar recortes culturais e espaciais:

(...) uma dimensão simbólica, cultural, através de uma identidade territorial atribuída pelos grupos sociais, como forma de 'controle simbólico' sobre o espaço onde vivem (sendo, também, portanto, uma forma de apropriação), e uma dimensão mais concreta, de caráter político-disciplinar [e político-econômico, deveríamos acrescentar]: a apropriação e ordenação do espaço como forma de domínio e disciplinarização dos indivíduos (HAESBAERT, 2006).

E a territorialidade,

não é apenas "algo abstrato", num sentido que muitas vezes se reduz ao caráter de abstração analítica, epistemológica. Ela é também uma dimensão imaterial, no sentido ontológico de que, enquanto "imagem" ou símbolo de um território, existe e pode inserir-se eficazmente como uma estratégia político-cultural, mesmo que o território ao qual se refira não esteja concretamente manifestado- como no conhecido exemplo da "Terra Prometida" dos judeus, territorialidade que os acompanhou e impulsionou através dos tempos, ainda que não houvesse, concretamente, uma construção territorial correspondente (HAESBAERT, 2007).

Definimos o patrimônio imaterial como toda e qualquer vivência, memória e experiência que tenha um significado maior, assim reconhecida e legitimada pelo grupo diretamente ligado a elas. E ainda, que diga respeito a uma herança, a algo que atinja a vida de uma coletividade, e que na maioria dos casos, traz em seu bojo valores e necessidades da vida humana. São práticas que reúnem experiências humanas naquilo que é comum e inalienável a todos os seres humanos. 
O que o patrimônio imaterial significa e promove é uma nova compreensão, uma nova forma ou forma diferenciada de olhar, é sair da aparência em direção à essência. Do império da fisicidade, do palpável e visível aos olhos, para o que está por trás, e a infinita gama de informações e conhecimentos que engendraram 0 produto/resultado final. É sair do o que para o quem. Da coisa para o sujeito e todo contexto seu cultural de produção. Do objeto em si para o processo que o levou a existir e como funcionou, o que significou e para o que foi utilizado.

Ora, podem dizer, 'mas já fazemos isso'. A diferença está em tirar o enfoque do objeto ou do produto final como uma obra acabada, única. E sob a qual maior sua engenhosidade, artificidade e ciência, maior será seu valor, maior o gênio que o criou, e que o individualiza como algo único, raro, insubstituível, colocado então como "o representante" do todo, como um chef d'oeuvre, ou um achado da ciência.

Trata-se do que chamo de "império das coisas", e a identificação máxima com elas, com o ter, ainda que ligado ao processo de formação da sociedade capitalista, o culto a forma, ao ter, ao consumo da coisa, do diferencial, do status. Isso pode ter influenciado em muito a seleção de coleções e o prevalecer dos museus a serviço de coleções. Nesta lógica, estarão os museus (tradicionais e de arte) fadados à famosa questão entre autencidade e a aura do objeto, apropriadamente denunciada por Walter Benjamin na questão da arte e a reprodutibilidade técnica, ad eterno?

Este caminho de reflexão também nos leva a oposição entre o que é reconhecido e elevado como a obra de um indivíduo para a história de processos, valores e significados que são partilhados e, portanto, coletivos - do indivíduo ao grupo, do micro ao macro, do erudito ao popular, da escrita à oralidade.

Aquilo que não pode se conservar pelo objeto, que the escapa, pois somente acontece no momento, na dinâmica da vida e nela se encerra, e cujo testemunho material é mero resultante. Não é a coisa em si, mas sim sua razão de ser. Não a obra da natureza e do engenho humano, mas a coisa em relação ao homem, o mundo que o rodeia e sua dinâmica, ou a dinâmica dessa interação. Do individual abre-se a diversidade, e a relação de opostos em constante dialética. O processo assim descrito pode ajudar a compreender, em parte, a aparente dificuldade de união entre as categorias de imaterial e material, mas que não é real, e que já acontece como a prática demonstra.

Na museologia, a aproximação do objeto a seu contexto de referência, seja na interpretação e apresentação desse objeto, foi alcançado mais de perto pelos museus 
de sociedade e ecomuseus. Embora estes ainda guardassem o aporte centrado no objeto para, a partir dele, preservar um processo de produção que o constituiu dentro de um contexto artesanal, agrícola ou industrial e desses em relação com o espaço e a natureza.

Nesse momento, diversos museus - como acontece com nosso objeto de estudo - preserva e musealiza testemunhos por meio da história oral, um papel fundamental para o registro e preservação dessa memória que ainda não existe registrada ou conhecida em grande parte. Daí pergunta-se: O patrimônio imaterial pode estar ligado à memória de dor, a locais ligados a traumas de guerras, violações de direitos humanos? Pois este tema tem ganhado grande vulto e se tornado matéria de muitas instituições museológicas em todo mundo. Questão controversa e que separa opiniões, esta posição cria prerrogativas questionáveis ao dizer que seria colocar a memória como um patrimônio. E então poder-se-á questionar: Então toda memória é patrimônio?

Fato interessante notar que as práticas já aceitas, e registradas como patrimônio imaterial têm, necessariamente, sempre e incondicionalmente, a memória a elas atrelada. A tradição, o saber, o fazer e a celebração ou remetem a ancestralidade de origem e/ou de antepassados, ou ao exercício mnemônico de transmissão por meio da tradição oral. Em todas essas operações a memória sempre está presente como ferramenta ou como elemento constituidor. A preservação da prática reconhecida serve também ao mesmo fim, ou seja, preservar a memória e a permanência da prática às gerações futuras.

Porque memórias relacionadas a guerras, resistências, libertação, dominação, emprisionamento não podem ter a legitimidade do patrimônio imaterial, como pode parecer na definição desta categoria patrimonial ou do quê vem sendo inventariado e registrado como tal?

Não se tratam de experiências humanas que deixaram legados, memórias e aprendizados a sociedades ou grupos, quiçá a humanidade, tanto quanto outras? Ou pelo simples intuito da não repetição de violência e deturpação da condição humana, não merece esta atenção? E por que diz respeito a uma necessidade premente de equanimidade, justiça social, consolidação da democracia, valores, cidadania, direitos humanos, formar a sociedade, contexto brasileiro em que tudo está ainda em construção. Por que não falar da dor ou da lembrança de traumas e violências sofridos? 
Voltar a este passado não serve a nada mais que transmutar um quadro de alienações, sofrimentos e deturpações para que se faça imperar a tolerância ou respeito às diferenças de credo, etnia, opção sexual etc; ao enriquecimento de saberes políticos e ideológicos dos sistemas sociais; para que se chegue a uma sociedade onde os direitos humanos sejam regra e não exceção.

A transmissão de memórias neste caso tem um fundamental papel educativo, em todas as idades, para construção de valores e de uma nova sociedade.Mais que uma sensibilização os museus dedicados a lembrança de traumas e violações tem um poder particular e incomensurável de aproximar experiências humanas, acionando dispositivos de afeto, memórias, identificação e verossimilhança com o presente (usar algo da psicologia), com um potencial a pedagogia da autonomia e da liberdade ${ }^{32}$.

Ou seja, a substância do patrimônio que aqui estamos falando e defendendo não servirá de certo aos critérios de unicidade, raridade e estética, segundo os quais seria considerado um patrimônio. Contudo, o que se defende aqui é o patrimônio como motor de desenvolvimento de um território e de uma comunidade, e neste caso, interessa sua utilização e resignificação para fins de desenvolvimento integral.

Ele (patrimônio) deve servir e ser um organismo vivo que possa receber nova função - seja ela se tornar um centro cultural ou de direitos humanos como "cai" bem em nosso objeto de estudo - ou que por consenso geral esse patrimônio represente: represente memórias, imaginários, afetividades, pertencimentos, seguidos de elementos estéticos, históricos, científicos ou políticos.

O bem cultural musealizado no MRSP ou os ligados a memórias de dor são imaterial ou intangível, e defendidos como um patrimônio por serem sim universais, apesar do perigo de definições de patrimônio universal, pois neste caso está acima de condições políticas e ideológicas. Diz respeito ao que todos os seres humanos tem em comum, a sua própria natureza, e a seus direitos inalienáveis, em tudo que ele deve ter garantido e respeitado - vide Declaração Universal dos Direitos Humanos. A musealização, nestes casos, tem um grande papel social: serve a denúncia e educação, para que outros não venham a sofrer violações, quaisquer que sejam. E o imaterial vem se relacionando intrinsecamente a essas novas categorias de espaços conhecidas como sítios de consciência, monumentos, lugares de memória e memoriais.

\footnotetext{
32 Termos cunhados por Paulo Freire, conforme sua formulação e definição.
} 


\section{4 - A memória e o direito à memória}

Sobre a memória, Andreas Huyssen posiciona uma onda de passados presentes a partir da década de 1980. A inversão da modernidade, das vanguardas (avant-gardes) e o espectro dos "futuros presentes" (HUYSSEN , 2000) deu lugar ao misto de desilusão e fragmentação vivido com a guerra, preço alto pago pelo nacionalismo levado ao extremo pelos regimes totalitários. E é a rediscussão desses regimes no espaço das mídias que faz emergir um novo patamar de memória. A experiência do Holocausto saiu do espaço dos sobreviventes ao que Huyssen chama de "globalização da memória", e passou a ser exemplo para todos os crimes e maus tratos de conflitos e infração grave aos direitos humanos. Como assinala:

"Não há dúvida que o mundo está sendo musealizado e que todos nós representamos os nossos papéis neste processo. É como se o objetivo fosse conseguir a recordação total. Trata-se então a fantasia de um arquivista maluco? Ou há, talvez, algo mais para ser discutido neste desejo de puxar todos esses vários passados para o presente? Algo que seja, de fato, específico à estruturação da memória e da temporalidade hoje, e que não tenha sido experimentado do mesmo modo nas épocas passadas. ${ }^{33 "}$

Nos debates entre passado, memória, presente e patrimônios, bem próximos ao presentismo "des lieux" apregoado por Hartog, dois elementos caminham juntos, e que são caracterizados por Huyssen como "obsessão contemporânea pela memória" e "medo do esquecimento", ambos públicos e coletivos.

Entre discursos e práticas nos museus muito já foi incluído (pessoas, identidades, novos discursos), assim como muito ainda não foi alterado. Entre avanços e recuos, alguns casos de museus podem nos ajudar a pensar em caminhos de (re) construção desses espaços em direção a uma condição de fórum, que dialogue com a sociedade e a convide à reflexão, onde uma reinvenção das ágoras seria possível. Alguns casos de museus e estudos nos dão pistas às questões que temos arrolado. $E$ é este o exercício que se propõe a seguir.

Hoje os museus rediscutem os princípios que os originaram. Grande parte deles está fundada na construção de uma nação ou do ethos nacional, dentro do

\footnotetext{
33 HUYSSEN, Andreas. Seduzidos pela memória. Arquitetura, monumentos e mídia. Rio de Janeiro: Aeroplano, 2000. p. 15.
} 
processo histórico particular articulado no século XIX, com a formação dos estados nacionais. Tal rediscussão é pautada por um novo parâmetro ou novo valor: a(s) Identidade(s). Ou ainda, do centralizador e unificador ao particular, individual e fragmentado.

As noções de história e museu também já vêm sendo rediscutidas e revistas. Os novos paradigmas apresentados na Mesa de Santiago do Chile, invocando a Nova Museologia e a Sociomuseologia, já tem reposicionado o papel dos museus, voltandoo a uma função social. Essas renovações das décadas de 1960, 1970 e 1980 encontraram outro ritmo do lado historiográfico ou para os museus de história. Em paralelo, as novas escolas e correntes historiográficas da Nova História, entre outras, não encontraram grande impacto nas exposições e processos dos museus de história (POULOT,2007). A bem da verdade, o exercício do historiador passou por muito tempo longe do campo dos museus, ou pelo menos, esse não foi seu lugar de escrita da história. Ao contrário foi alvo de crítica ou de reivindicação - já que os museus congregam outros profissionais, e não concentram historiadores e regras acadêmicas da historiografia. Fato é que a história dos museus ainda está por ser escrita.

Por outro lado, percebem-se aproximações da Escola dos Annalles, e sua história das camadas sociais mais baixas ou de comunidades em experimentações, como o museu laboratório implantado por Georges Henri-Rivière e seus sucessores. Mesmo que tal influência não tenha atingido proporção semelhante à alcançada pela Antropologia e pela Etnologia, sob o fazer museográfico/museológico. Fato esse que não pode perder de vista suas diferentes proporções. Isto é, a Antropologia recebeu incremento enquanto ciência justamente dentro dos museus, seu lugar de nascença, diferente da História. Ainda nesse contexto:

"L'invention de l'écomusée ou du musée de société a largement participé d'un mouvement de retour sur soi de l'anthropologie, du lointain au proche: l'anthropologie de la France s'est élaborée à ce moment, remplaçant em quelque sorte l'anthropologie de l'autre par celle du même. Les causes em sont complexes, qui mêlent le processus de décolonisation, la reconversion de l'anthropologie universitaire, enfin l'élaboration d'une demande publique grâce à la Mission du Patrimoine ethnologique, qui est venue complexifier la situation entre la recherche et lês musées. ${ }^{34 "}$

\footnotetext{
${ }^{34}$ "A invenção do ecomuseu ou do museu de sociedade tem participado largamente de um movimento de retorno da antropologia sobre si mesma, do longínquo ao próximo: a antropologia da França se reelaborou, substituindo de alguma forma a antropologia do outro por aquela do "ele próprio". As causas são complexas, e misturam o processo de descolonização, a reconversão da antropologia universitária, enfim, a elaboração de uma demanda pública graças a Missão do Patrimônio Etnológico
} 
O mesmo museu fundado por Rivière foi alvo de análise de Camille Mazé. O Museu National de Artes e Tradições populares, assim como vários outros referidos pela autora, foram alvo de uma reestruturação na década de 1990. Essa reestruturação de museus se iniciou para outros na década de 1980, como é o caso de museus da Alemanha. O Museu National de Artes e Tradições populares foi extinto em 2005, assim como a maioria deles teve suas coleções transferidas para novos museus $^{35}$. O que todos eles têm em comum é a característica de ser um museu nacional em transformação para um novo tipo de museu: se tornar um museu do continente europeu, com coleções européias, os "Museus da Europa". A partir de antigos museus ou da criação de novos, eles pretendem formar uma "cultura da Europa", e estão fundamentados segundo a análise de Mauzé: a História e a Etnologia em especial são instrumentalizadas para a construção de identidade e alteridade. A diferença é que essa identidade estava fundamentada no nacional, e na ideia de nação, passa a cristalizar um preceito mais globalizante, que é a ideia de uma Europa comum, de características, formação e identidade comuns. Na verdade, neutralizações de tempo, espaço e lugar com o objetivo de criar uma origem comum e uma unidade que não existem ${ }^{36}$.

Os museus nacionais têm adotado diversos modelos e características. Mas sintomaticamente, os museus de Etnologia e Antropologia serviram aos países colonizadores para a fundamentação da ideia de nação, de forma singular, forjada na imagem do "outro" e da diferença.

que trouxe complexidade a relação entre a pesquisa e os museus." Dominique Poulot. Le musée d'histoire en France entre traditions nationales et soucis identitaires. Anais do Museu Paulista. São Paulo. N. Sér. v.15, n. 2, p. 293-316. jul.-dez. 2007.p. 301.

35 O Museu Nacional de Artes e Tradições Populares (Musée National des Arts et Traditions Populaires MNATP), teve sua coleção - juntamente com a coleção do Museu Nacional de Artes da África e Oceania (Musée National des Arts d'Afrique et d'Océanie - MNAAO) extinto em 2003, enviada ao Museu do Quai Branly (inaugurado em 2006), e ao Museu das Civilizações da Europa e do Mediterrâneo (Musée des Civilisations de l'europe et de la Méditerranée - MuCEM), localizaod em Marselha, aberto em 4 de junho de 2013. O Museu do Homem (Musée de l'Homme - MNH), permanece fechado em reestruturação com previsão de reabertura em 2015. No mesmo contexto, foi inaugurada em 2007 a Cidade Nacional da História da Imigração (Cité Nationale de l'histoire de l'immigration - CNHI). Sobre o tema ver: Um palácio para a imigração? Uma apresentação da Cité nationale de l'histoire

de l'immigration na França. Andrea C. J. Delaplace. Revista CPC, São Paulo, n.14, p. 087-105, maio 2012/out. 2012. Disponível em: http://www.usp.br/cpc/v1/imagem/conteudo_revista_colecao_arquivo_pdf/247.pdf

${ }^{36}$ Sobre isso ver em Andreas Huyssen como as categorias de tempo e espaço se interpõem a todo exercício humano cognitivo. Op. Cit. 2000. 
Este outro como símbolo máximo de alteridade, hegemonia ou simplesmente de exótico teve sua primazia, ao longo do século XIX e boa parte de século XX em museus históricos, de arte, de antropologia e etnologia. O museu, como lugar máximo de representação, colocou o outro na função de assimilação e de afirmação para a integração nacional dos países colonizadores. Fossem eles "primitivos" ou "premiers" ${ }^{37}$ nunca saíram da linha evolucionista da História. A noção de etinicidade ${ }^{38}$ passou a figurar e definir o que é patrimônio, notoriamente nas classificações adotadas na França, onde o poder de definição do que é patrimônio é tomado por grupos e comunidades, quanto até então, somente Estado mantinha hegemonia sob essa tutela. A Identidade (social) passa a ser o mote para identificação de patrimônios. A etinicidade entra aí como consciência de pertencimento a um grupo. Mauzé situa o fim da década de 1980 - e novamente a década de 1980 - como o período de crise e declínio destes museus nacionais enquanto modelo (sejam eles históricos ou etnológicos). Os novos contextos de mundialização, disputas políticas e movimentos sociais não correspondem mais aos emblemáticos discursos uniformes. Assim, os novos museus de civilização europeus parecem somente reforçar o velho no novo.

Mesmo os maiores episódios revolucionários, com forte participação popular e mudança brusca na ordem das camadas sociais, são mostrados em museus em suas dicotomias, sem conseguir manter um discurso totalmente único. O exemplo da Revolução Mexicana é singular nesse âmbito, pois a contramarcha conservadora não eliminou o discurso socialista capilarizado nas pinturas muralistas. A repressão aos movimentos sociais posiciona e reposiciona o lugar dos revolucionários - heróis emudecidos - que também pode ser esvaziados do tecido social ao qual pertencem, e elevados à condição de herói oficial. A construção da história da Revolução Mexicana no Museu Nacional de História do México, em todas as suas várias fases e reformulações a exposição, é mais um exemplo em como os museus fazem-se e refazem-se sem, na verdade, tantas diferenças ou mudanças ao estado anterior ${ }^{39}$.

Este tem sido o comportamento típico de museus nacionais que enfrentam problemas de se superar enquanto modelo, ao passo que outros são criados sob as

\footnotetext{
${ }^{37}$ Fala-se aqui da paixão europeia pelas "artes primitivas". Mais sobre no trabalho de Sally Price.

38 Noção que surge primeiramente entre os sociólogos, invade as ciências humanas e encontra caso particular na década de 1950 entre os sociólogos norte-americanos, quando esta sociedade enfrentava conflitos urbanos e de enfrentamento étnico. Duas obras para essa noção, de 1995, trazem uma teoria da etnicidade, de Poutgnat\&Streiff. POUTGNAT, P. \& STREIFF-FENART, J. Teorias de Etnicidade. São Paulo: Unesp, 1998.

${ }^{39}$ Com base no estudo desenvolvido por Camilo Vasconcellos, em Imagens da Revolução Mexicana. 0 Museu Nacional de História do México 1940 - 1982. São Paulo: Alameda Editorial, 2007.
} 
mesmas bases. São museus que tomam a nação como categoria, tema e problemática, ainda hoje em curso, e até aqui colocados de forma homogeneizante, pedagógico e linear. Somente uma condição não é perdida: a de museu = lugar de memória, dinâmico, em constante mutação, e em constante disputa.

As mesmas questões se repetem nos estudos de museus realizados por Johanna Heinen sobre os museus judaicos de Berlin, e Mary Stevens sobre a criação da Cidade Nacional da História da Imigração (CNHI). Em locais diferentes o mesmo problema dos discursos unívocos persiste. E o "outro" retorna ao centro da atenção, agora na posição de imigrante, reposicionado em parte nesta relação, já que o museu permanece o lugar do "eu" em relação ao "outro". Mesmo o paralelo aos museus de comunidades específicas como os museus judaicos, ainda não encontram uma fórmula que contemple os judeus e "os não judeus" no mesmo discurso e apresentação expográficos.

Todos os exemplos citados podem ser reunidos a uma mesma indagação: a quem pertence o monopólio do discurso, a quem ele serve, quem o patrocina, e como mantém sua permanência?

A onipresença da noção de memória e sua supervalorização podem e devem ser perpassadas pela subjetividade, presente na arte humana. Tudo que o humano produz de imaterial, em suas manifestações sociais e culturais, materializadas em formas culturais, podem ser chamadas de patrimônio, mas quando e somente quando ele representar de fato o grupo, um conjunto, uma comunidade, que dele usufrui.

Como instituições oficiais e históricas de preservação e ligadas aos patrimônios culturais, os museus não podem passar a margem do contexto que inclui o imaterial, as identidades e os anseios da sociedade que ele representa. Não seria justamente essa a forma de, finalmente, trazer e aproximar definitivamente toda a sociedade dos bens que lhes pertencem? 


\section{Capítulo 2}

\section{Conceitos e práticas em aproximação}

\section{1 - No contexto do objeto: as ditaduras, a Justiça de Transição, as políticas de memória e a patrimonialização de locais de dor}

Pensar os museus historicamente e pensar o papel e lugar dos museus de história hoje. Este é o melhor ponto de partida, pois todos os museus tem uma trajetória histórica. Assim como todos os objetos de estudo da História, os museus são fruto de uma operação intelectual do presente, situada no presente, sobre o passado. Coleções, objetos e documentos são, portanto, testemunhos parciais do passado tratados a partir de problemáticas do presente. Os museus de história, em particular, lidam com questões identitárias. Em suas várias reformulações apresentam narrativas discursivas alicerçadas em experiências de memória, legitimadoras de poder, muitas vezes apresentados como discursos unívocos. Muitas dessas identidades estão sólidas, e permanecem cristalizadas desde o século XIX, fazendo dos museus lugares conservadores. Mas os processos históricos contemporâneos adentram os museus e os provocam a se defrontar com a sociedade. Assim, o museu deve ter um discurso certo, mas onde fica seu lugar de fórum, de reflexão aberto de ideias? Para que servem os equipamentos culturais? Todas essas questões perpassam meu projeto de pesquisa na medida em que trato de questões contemporâneas em um museu, construído a partir de memórias, de um tema histórico contemporâneo e traumático (que são os regimes ditatoriais), que toca na questão da identidade e do papel do museu frente ao passado e as demandas atuais da sociedade.

A memória seguida de sua publicização por meio da patrimonialização de locais de sofrimento, ou violações aos direitos humanos, é consequência do processo de não reparação, e não aplicação da devida justiça em prol das vítimas, o que deveria incluir a condenação dos infratores. Faz correr em sentido inverso: antes de a justiça acontecer, a memória se tornou uma arma, uma ferramenta que faz a coletividade conhecer fatos ocultados na historia oficial, por interesses diversos. Tem sido também a forma de justiça mais ampla e acessada pelas vítimas, que mesmo tendo sido contemplados por reparações econômicas, ainda está longe de ver se concretizar seu maior objetivo: a punição dos infratores e torturadores pelos crimes cometidos. 
"Além do valor para os direitos humanos, os Lugares de Memória têm valor histórico e cultural. No plano jurídico, por serem a materialização da memória de um período histórico, enquadram-se na concepção de sítios de valor cultural, previstos na Constituição (Art.216, inc.V). Por isso, a concepção, instalação e gestão desse tipo de local envolvem políticas públicas para os direitos humanos (com enfoque na reparação das vítimas e também para que a violência nunca mais aconteça) e políticas culturais, comações ligadas à gestão e proteção dos bens culturais,especialmente de museus, memoriais, arquivos públicos e outras ações que ajudem a compreendera história do país durante a ditadura militar."(SOARES, 2012) 


\section{2 - O Memorial da Resistência de São Paulo}

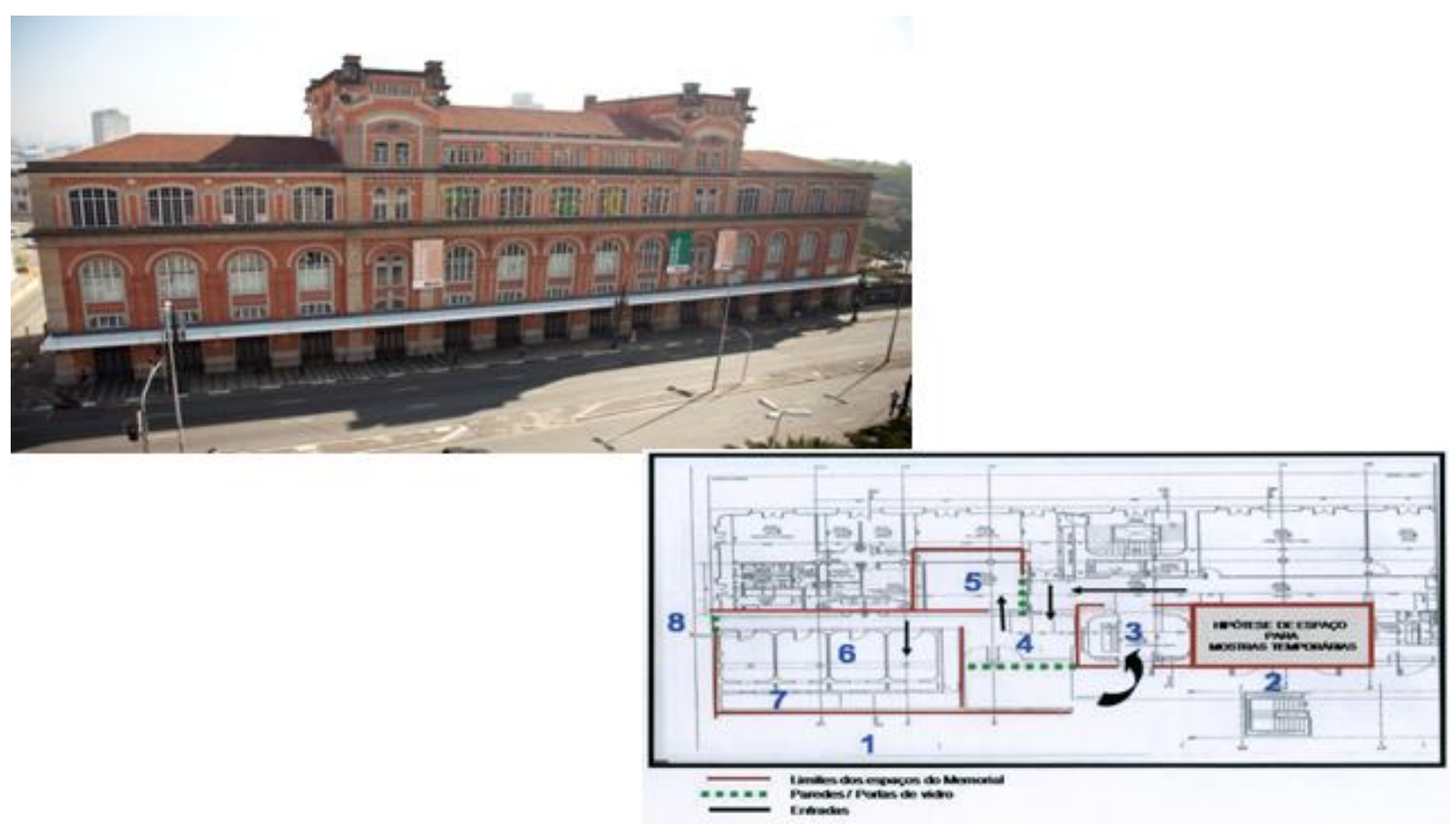

Fachada do edifício e croqui de espacialização elaborado no início do projeto Museológico de Ocupação (2007). Acervo Memorial da Resistência de São Paulo.

\subsection{1 - Breve histórico institucional}

Em 1924, mais precisamente em 30 de dezembro de 1924, pela lei número 2034, estabeleceu-se no então Gabinete de Investigações e Capturas do Estado de São Paulo a Delegacia de Ordem Política Social, o DOPS. Sua finalidade maior era manter sob controle as ações dos cidadãos em geral. Essa polícia de caráter nacional instalou departamentos estaduais por todo o país, sobretudo nas grandes capitais, dentre elas, São Paulo.

Durante os anos de sua existência o Deops/SP (Departamento Estadual de Ordem Política e Social), criado pela lei $\mathrm{n} .{ }^{\circ}$ 2.034/24, passou por várias denominações ${ }^{40}$. Em 1945, o Deops/SP passa a ter 5 delegacias separadas: Ordem

\footnotetext{
40 Somente no período de 1924-1945 o DEOPS/SP mudou 11 vezes de nome. A denominação dessa delegacia especial alternou entre Delegacia de Ordem Política e Social (1924, 1938 e 1944); Delegacia Especializada de Ordem Política e Social (1930-1931-1938), Superintendência de Ordem Política e Social (dezembro de 1930 e 1934), Superintendência de Segurança Política e Social (1940).In: AQUINO, Maria
} 
Política, Ordem Social, Estrangeiros, Armas e Munições, e Ordem Econômica ${ }^{41}$. Todas essas delegacias foram instaladas, a partir de 1940, no edifício situado no Largo General Osório, número 66. O endereço passaria a tornar-se referência por conta da presença da polícia política, onde ela permanece até sua extinção em 1983.

Originalmente, a edificação foi construída para a Estrada de Ferro Sorocabana cuja linha férrea está logo atrás, passando hoje pelas Estações da Luz e Julio Prestes. Abrigou a administração e um dos armazéns da Sorocabana de 1914 a 1940. O projeto arquitetônico é do escritório de Ramos de Azevedo.

Em 1940 a primeira delegacia a se instalar foi a Delegacia Especializada de Explosivos, Armas e Munições. O Deops/SP foi extinto em 1983, seguindo o fim da ditadura civil-militar. $O$ prédio permaneceu em posse da policia estadual, que ali instalou o Decon - Delegacia de Defesa do Consumidor, órgão da Polícia Civil, em funcionamento até o ano de 1997. Com a transferência da delegacia, o edifício é fechado com posse da Secretaria de Justiça. No ano seguinte (1998), a posse foi transferida para a Secretaria do Estado da Cultura.

Com a extinção do Deops/SP em 1983 seus patrimônios seguem caminhos diferentes. O prédio permaneceu em uso policial até 1997, mas toda documentação produzida pelo órgão fora transferida para a alçada da Polícia Federal. Em 1991 esta documentação é transmitida à Secretaria de Estado da Cultura que a mantém no Arquivo do Estado de São Paulo. A documentação do Deops/SP tornou-se pública em 1994, com seu acesso liberado a todos os cidadãos.

Voltando ao edifício, sua transferência à Secretaria do Estado da Cultura ocorreu após a intervenção reivindicatória de diversos grupos organizados: ex-presos políticos e familiares de mortos ou desaparecidos políticos, organizações de Direitos Humanos e instâncias governamentais frente ao Estado.

Uma vez voltado à área cultural, iniciaram-se projetos e reformas reestruturais com vistas à recuperação do edifício. A primeira grande reforma foi empreendida pelo escritório de arquitetura Haron Cohen. Em 1999, o edifício é tombado pelo

\footnotetext{
Aparecida de [et al] (orgs.). No Coração das Trevas: o DEOPS/SP visto por dentro. São Paulo: Arquivo do Estado, Imprensa Oficial. 2001. v. 1, p. 19.

${ }^{41}$ Conforme o decreto-lei de 14.854. In: AQUINO, Maria Aparecida de [et al] (orgs.). No Coração das Trevas: o DEOPS/SP visto por dentro. São Paulo: Arquivo do Estado, Imprensa Oficial. 2001. v. 1, p. 35
} 
Condephaat. Obras e restauro foram concluídos em 2002 e a inauguração ocorreu em julho de $2002^{42}$.

Mas qual foi o destino dado à edificação patrimonializada?

Muitos projetos diferentes foram pensados pela Secretaria de Cultura. O primeiro, e que chegou a receber placa na fachada foi a Universidade Livre de Música (ULM), que não vingou e foi instalado em edificação histórica logo à frente, também no Largo General Osório. A ideia da escola de música ou teatro foi substituída pela criação do Museu do Imaginário do Povo Brasileiro ${ }^{43}$ e do Memorial da Liberdade ${ }^{44}$. 0 primeiro não chegou a sair do papel. O segundo foi efetivado e consistiu na abertura do espaço prisional, totalmente reconfigurado em relação ao estado original e com apenas quatro celas. De 2002 a 2006 o espaço apresentou exposições temporárias de temas correlatos à ditadura e a documentação do Deops/SP, nesse período gerido pelo Arquivo Público do Estado.

O Memorial da Liberdade ocupou, em verdade e na maior parte do tempo, o espaço térreo correspondente ao antigo espaço carcerário. A partir de 2004, o restante do edifício passou a acolher atividades da Pinacoteca do Estado, que criava sua segunda sede, a Estação Pinacoteca ${ }^{45}$, que também recebe a gestão do edifício em 2007.

Graças a intensas mobilizações e insatisfações, em especial por parte do Fórum Permanente de Ex-presos e Perseguidos Políticos do Estado de São Paulo, um novo projeto foi aceito e viabilizado, dando origem em 2008 ao Memorial da Resistência de São Paulo. Vale destacar que as principais reclamações referiam-se ao fato da total descaracterização da história daquela delegacia e prisão política, seja pela reforma levada a cabo, seja pelo nome Memorial da Liberdade. E ainda, a particularidade de conversa e interlocução permanente do Fórum com o poder público.

\footnotetext{
${ }^{42}$ Entre as propostas em como utilizar o novo prédio, a Secretaria da Cultura projetou sua inserção nos projetos de revitalização da região central da cidade, transformando-o em uma escola de música ou teatro, além de iniciativas que lembrassem a função original de prisão do Deops/SP. Isto significa dizer que tudo o que concernia ao funcionamento do Deops/SP foi paulatinamente sendo desmembrado e, em grande parte, descartado.

${ }^{43}$ Segundo Decreto no 46.507 de 21 de janeiro de 2002. Apesar de não efetivado, chegou a ter elaboração de um programa museológico com curadoria de Emanoel Araújo e participação da empresa Expomus Exposições, Museus e Projetos Culturais.

${ }^{44}$ Criado pelo Decreto no 46.900, em 05 de julho de 2002. Anterior à ele, havia sido criado o Memorial do Cárcere (Decreto-lei no 46.508, 21/jan/2004), revogado pelo Decreto no 46.900.

45 Instituído pelo Decreto no 48.461 de 20 de janeiro de 2004 que também extingue o revogado no Decreto 46.507 referente ao Museu do Imaginário do Povo Brasileiro. A Estação Pinacoteca tem por missão a difusão museológica na área das artes visuais, onde também se localiza para tal a Biblioteca Walter Wey, o Centro de Documentação e Memória (CEDOC), e o Auditório Vitae.
} 
A crítica tem imensa validade ao pensar o longo trajeto de política repressiva empregados pelo órgão ou pela polícia brasileira de modo geral. Desde o ano de 1921, decretos, leis e atos institucionais foram incluídos na legislação federal para tratar do que se denominaria crime político, e reestruturar a polícia. Há também uma série de leis instauradas entre 1924 e 1983 na legislação estadual de São Paulo, que regularam o funcionamento dos órgãos policiais, incluídas aí as diversas mudanças internas pelas quais passou durante sua existência.

Mas, por trás da ação desta Polícia Política esteve a figura soberana do Estado que mantinha e legitimava a ação do novo órgão. E foi este Estado, que tomou para si a missão de liderar um novo projeto social para o Brasil, projeto esse inteiramente pensado em bases autoritárias ${ }^{46}$.

Portanto dentro desse projeto social que se delineava, o DOPS (em nível federal), tornava-se um importante elemento da construção de um Estado forte, que pretendia construir a imagem da nação, o que implicava homogeneizar a sociedade. Assim, nos momentos de crise e instabilidade política o Estado, com a colaboração da polícia política, identificou diferentes inimigos da Nação Brasileira e trabalhou no sentido de eliminá-los da sociedade. Eram eles anarquistas, comunistas, integralistas, antifascistas, nazistas, feministas, nipônicos, terroristas, subversivos, vadios ou delinquentes, etc.; dependendo do período em questão.

Essa polícia é especializada em crimes políticos, uma ordem especial de crimes, diferenciados dos crimes considerados comuns. Mas, o que é crime político? É estar na condição de criminoso por expressar opiniões contra a ordem vigente, contra o Estado, um crime contra a ordem nacional. ${ }^{47}$ O DOPS nasce em um contexto de intensa agitação social, ideológica e política, com intenção de coibir as manifestações

\footnotetext{
46 Tem-se um novo projeto de Estado, responsável por promover o sentimento de nacionalismo, unidade e identidade nacionais. Todos legitimados através de estratégias autoritárias de dominação e controle social, impondo um estado de vigilância ininterrupto, utilizando-se da violência e do terror. Foram delegados à polícia poderes acima da lei, para cumprir função de executora, munida de todo um aparato. Isto foi possível com as reformas da Polícia do Distrito Federal e da Polícia Civil, controlando capitais e Estados, além dos órgãos de propaganda política como o DIP. O código Penal de 1890 precisava ser mudado para que a ação da polícia fosse possível como principal alicerce do regime ditatorial. Este código recebe uma série de críticas e é reformulado conforme os princípios da Escola Positiva, claramente lançando bases de dominação. Assim em 1932 foi feita a Consolidação das Leis Penais e, em 1940, o Estado Novo aprova o Código Penal que entrou em vigor em 1942. A criminologia (Escola Positiva e Antropologia Criminal) transferiu o foco de atenção do delito para o agente do delito.

47 TEIXEIRA, Karina Alves. Imagens e palavras construindo realidades. A fotografia como instrumento político do Deops/SP (1924-1945). Trabalho de Iniciação Científica pela Fapesp/Proin, sob orientação do Prof. Dr. Boris Kossoy e Prof.a. Dra. Maria Luiza Tucci Carneiro. 2002-2004.
} 
sociais em curso. E foi ainda mais fortalecido e desenvolvido nos períodos autoritários vividos no país: 1930 a 1945 (Período Vargas), e 1964 a 1985 (Ditadura civil-militar).

Preocupados em definir e comprovar o crime político, as autoridades policiais procuravam manter sob vigilância a população. Assim, os diferentes segmentos sociais foram vigiados e julgados como subversivos da ordem, através de todo um aparato estatal composto por instituições jurídicas, políticas, legais e penais que davam bases a polícia política, que pôde assim ter uma atuação marcante na vida social brasileira.

Para tal a polícia contou com um aparato técnico-cientifíco que tinha apoio na produção intelectual da medicina legal, da polícia científica e da Antropologia Criminal que procuravam combater o crime em bases científicas. Essa produção teórica e técnica trabalhava o crime como desvio social. Intelectuais da criminologia, através de um pensamento pautado no determinismo biológico, atuaram na formação da Escola Positiva do Direito Criminal, ou Escola Antropológica, inspirados em autores como Cesare Lombroso, Enrico Ferri e Rafaelle Garofalo, sobretudo no primeiro período de existência. Já para a ditadura civil-militar as bases vêm da polícia norte-americana e das práticas de seus serviços de inteligência.

A data de criação e inauguração do Memorial da Resistência é quase simbólica: $1^{\circ}$ de maio de 2008. Um 1ํ de maio, cuja tradição é representar a luta dos trabalhadores, para o lugar que passaria a representar estas e várias outras lutas políticas do país.

Denominado de "Projeto Museológico de Ocupação", um projeto já havia sido apresentado para reformulação do então Memorial da Liberdade, em 2007, com intenção de torná-lo um "centro de referência da memória política brasileira". Mas a mudança efetiva do nome para Memorial da Resistência de São Paulo ocorreu no $1^{\text {o }}$ de maio de 2008. Já o início dos trabalhos de implementação do processo museológico que deu origem ao Memorial de Resistência ${ }^{48}$ e da nova instituição museológica ocorreu em agosto de 2008.

Como pressupostos, o projeto reconhece a reconfiguração efetuada pelos restauros, um aniquilamento da memória e da História, que tenta apagar a severa

\footnotetext{
${ }^{48}$ Goldman inaugura o Memorial da Resistência. Secretaria de Desenvolvimento Econômico, Ciência e Tecnologia. Notícias. Portal do Governo do Estado de São Paulo. 02/05/2008. http: \\ www.desenvolvimento.sp.gov.br/noticias/?ID=838. Consulta de 26/03/2013.
} 
repressão e infração dos direitos humanos cometidas pelo Estado e por causas ideológicas, cujo local é lugar de memória latente.

Como o projeto cita, essa "produção intencional de silêncios" ocorreu fisicamente através da descaracterização das instalações originais, mas também pelo redirecionamento quase que exclusivamente à cultura e finalmente a ocupação pela Estação Pinacoteca sem parentesco histórico com o local. No espaço outrora legado ao Memorial da Liberdade inexistia a memória da repressão efetuada tampouco as marcas e vozes dos que a sofreram.

O "Projeto Museológico de Ocupação" foi concebido em 2007 quando da elaboração de uma nova proposta reformativa do antigo Memorial da Liberdade, e levado à prática em $2008^{49}$. O programa museológico do Memorial teve suas bases lançadas neste projeto. Nele foram estipulados o conceito gerador museológico, a estrutura e metodologia de trabalho para realização do programa museológico, as linhas de ação museológicas, proposição do roteiro expositivo e da ação educativa e cultural. Estas bases deram sustentação para o desenvolvimento do programa museológico e posteriormente ao plano museológico consolidado pela já instituição Memorial da Resistência de São Paulo ${ }^{50}$. A inauguração e abertura ao público se deram em 24 de janeiro de 2009.

Os trabalhos tiveram início com a formação de uma equipe multidisciplinar que, a partir do projeto de ocupação, passou a chamada "fase de implantação". Nela a equipe reviu os pressupostos do projeto e lançou mão de estratégias para a viabilização da preservação do espaço carcerário, e os novos caminhos a adotar para sua transformação em uma herança patrimonial. Nesta fase foram tomados como partido:

- o enfrentamento do abandono, renovando os vestígios do passado repressivo com intuito de lhe dar novo destino;

- a preservação entendida como "um conjunto de ações vocacionadas à interpretação dos bens culturais com vistas à respectiva proteção, mas, especialmente, com o propósito de gerar trocas alternativas para a compreensão da herança patrimonial";

\footnotetext{
49 Projeto apresentado em 10 de agosto de 2007, por solicitação do então diretor da Pinacoteca do Estado Marcelo Mattos Araújo. Projeto elaborado por Maria Cristina de Oliveira Bruno (museóloga), Maria Luiza Tucci Carneiro (pesquisadora e professora universitária) e Gabriela Aidar (educadora, atua na Ação Educativa da Pinacoteca do Estado).

${ }^{50}$ Após a implantação e inauguração ao público, o Memorial da Resistência deu prosseguimento a sua consolidação enquanto instituição. Assim, ao longo de 2009, elaborou o seu plano museológico o qual vem aplicando desde então.
} 
- usar como estratégia procedimentos de salvaguarda e comunicação dos bens patrimoniais que darão fruto a interpretação e a novos significados para os bens culturais em questão, bem como a ações pedagógicas.

O Memorial da Resistência contou com um processo de implantação diferenciado. Como já exposto, o local foi muito modificado. Por isso, a responsabilidade unida ao desafio em retrabalhar os fatos ali vividos, se tornaram ainda mais difíceis, sobretudo porque a equipe não poderia contar com o histórico material do prédio, ou qualquer outro vestígio aparente para remontar qualquer versão de passado possível.

Como então recuperar o que o Deops/SP representa, e de modo a tornar isso um bem social, cultural e transformador, que proporcione um diferencial à sociedade?

Um trabalho de arqueologia e intensa pesquisa histórica se fazia necessário. Mas, não foi por meio de escavações que as informações surgiram. O principal terreno de exploração foi um terreno sutil e subjetivo: o das memórias. Também não foram apenas profissionais e especialistas os responsáveis pelas informações levantadas. A equipe de profissionais optou pelo reforço de pessoas que viveram os acontecimentos históricos do período ditatorial civil-militar.

Fazendo jus às reivindicações feitas ao governo do estado de São Paulo, os ex-presos políticos foram chamados a participar da reconstrução histórica e da reconfiguração física do espaço carcerário. Como reforça a coordenadora da instituição, que fez parte da implantação desde seu início, foi decidido que seriam os "protagonistas" que trariam a mensagem e as informações sobre aquele espaço. E que o discurso seria pautado na chave da resistência. Primeiro porque esta era uma exigência ou prerrogativa dos ex-presos, e segundo, porque encontrava ressonância nas intenções da equipe, em apresentar um discurso de viés positivo de reconstrução, e não apenas focado na repressão ${ }^{51}$.

A participação de ex-presos políticos ocorreu em várias etapas do processo: a recuperação de suas memórias foi base para exposição de longa duração. Eles tomaram lugar e foram as fontes históricas. Conforme foi relatado, isso significou não apenas a coleta das informações, mas a interlocução de debates, discordâncias, escolhas e negociações sobre qual a memória seria apresentada através do Memorial. Muitas memórias e memórias discordantes, sobretudo evidenciadas na reconstituição do espaço prisional. O importante a ressaltar é que os ex-presos participaram da

\footnotetext{
${ }^{51}$ Kátia R. Felipini Neves em entrevista concedida em maio de 2014.
} 
decisão de definições discursivas sobre o que seria dito e como seria apresentado. Decisões que perpassaram não só a escolha dos conteúdos - leia-se aí também a versão da história escolhida. O grupo de ex-presos auxiliou na escolha dos argumentos, temas a serem trabalhados, e elementos para reconstituição do espaço. Dos testemunhos também nasceram as bases para definir a noção de resistência a ser adotada, de acordo com o sentido que eles (ex-presos) imprimem à experiência de ter vivido a prisão e a perseguição político-ideologico ${ }^{52}$.

O processou abrangeu a realização de sessões de entrevistas para coletas de testemunhos, reuniões setoriais, e a participação de diversos profissionais para a concepção geral e execução do projeto expográficos. Um trabalho feito a muitas mãos que contou uma equipe multidisciplinar, a estrutura e coordenação da Pinacoteca do Estado e o envolvimento de seus profissionais, além de consultores externos, a Secretaria de Cultura, e outras instituições como articulação com o Arquivo Público do Estado de São Paulo (AESP).

\subsection{2 - Estrutura museológica}

Criar e adotar novos conceitos e suas orientações implica necessariamente, dentro dos museus, a criação subsequente de uma política de salvaguarda e de métodos para realizá-la. Nossa matéria aqui é o intangível que escapa completamente a forma tradicional (e ocidental) de tratar bens móveis e imóveis, com suporte na tradição escrita. A efemeridade do intangível tem como suporte principal a oralidade a Memória e a memória oral.

Do lado técnico, a pesquisa e suas etapas são a Pesquisa/Coleta/Registro, alicerçadas nas tecnologias digitais de armazenamento e processamento utilizando áudio, vídeo e bases de dados. E claro, a criação de centro de referência para referenciar pessoas, lugares e acervos de todos os tipos, propiciando uma base temática e em rede de informações.

\footnotetext{
${ }^{52}$ Memorial da Resistência de São Paulo. ARAUJO, Marcelo Mattos e BRUNO, Maria Cristina Oliveira (Coord.); NEVES, Kátia Filipini [et al.]. São Paulo: Pinacoteca do Estado, 2009. P. 61.
} 
No caso do Memorial da Resistência de São Paulo, os progrmas de pesquisa, perpassam o papel tradicional do programa cientifico de um museu. Eles denotam um papel mais ativo e orgânico dentro da estrutura museológica e institucional. Eles foram criados com a intenção de alimentar e retroalimentar a instituição. E esta pesquisa tem um caráter muito particular, pois trata-se da criação de um acervo, e não apenas da formação de uma coleção, ou trabalho em cima de uma coleção pré-existente. Este acervo está sendo criado a partir de uma coleta sistemática e permanente de testemunhos de ex-presos políticos e militantes, familiares, advogados, e outros que tiveram contato com o edifício Deops/SP durante seu funcionamento.

Segundo os documentos institucionais e contato com seus profissionais, os testemunhos são colocados como fonte para levantar informações e alimentar as exposições, as ações culturais e educativas. O plano museológico tem a ambição de que os Programas ou Linhas caminhem juntos em sistema de retroalimentação.

No plano museológico estão estabelecidos os princípios que alimentam todos os demais seguimentos. Nele também estão indicados os processos de desenvolvimento das linhas programáticas, entendido como fases, e que prevê em primeiro lugar a "implantação das Linhas Programáticas do MRSP" (fase 1); a "consolidação do Conceito Gerador do MRSP" (fase 2); a "expansão institucional do MRSP" (fase 3$)^{53}$. Em todas as fases estão postas e previstas a expansão de todas as linhas de ação programáticas, assim como, a conquista da autonomia institucional, posto que o Memorial da Resistência é gerido a Organização Social Associação Pinacoteca Arte e Cultura, e administrativamente ligada a Pinacoteca do Estado, equipamentos da Secretaria de Cultura do Estado de São Paulo. A expansão prescinde da contratação de profissionais e da ampliação de parcerias.

O plano museológico foi realizado com base em um estudo preliminar do qual foi extraído o perfil da instituição museológica em questão, suas potencialidades e necessidades, com vistas a sua consolidação e crescimento. Suas diretrizes seguem o que já fora estabelecido pelo projeto inicial de criação do Memorial da Resistência, concebido em (2008).

Precebe-se que a avaliação museológica tem sido um ponto de atenção na instituição e também em processo de desenvolvimento. A instituição se utiliza de algumas ferramentas (livro de visitas, filipetas, avaliações de público periódicas,

\footnotetext{
${ }^{53}$ Plano Museológico. Elaborado por BRUNO, Maria Cristina Oliveira; ARRUDA, Beatriz Cavalcanti; FIGOLS, Franscisca Aida Barbosa. Memorial da Resistência de São Paulo, Associação Pinacoteca Arte e Cultura/Pinacoteca do Estado. São Paulo, 2010. P.50
} 
avaliações sistemáticas das visitas educativas, e um email institucional), para comunicação e aferição da opinião do público visitante. Contudo, o potencial dessas informações ainda não foi utilizado em sua totalidade, a começar pelo fato de que a maior parte das avaliações, embora coletadas em constância, não conseguem ser tabuladas e processadas no cotidiano dos trabalhos.

O espaço prisional foi tomado como o "eixo gerador" da exposição de longa duração e das ações de comunicação, educação e extroversão do Memorial da Resistência. Pode-se dizer que esta tem sido a base de sustentação do Memorial, pois além de serem as linhas imediatamente postas em execução quando de sua inauguração, são também a porta principal de entrada e fruição do público, por meio do principal produto do museu, sua exposição de longa duração. As linhas de educação e ação cultural são as mais desenvolvidas até aqui.

"Essas linhas de ação, que foram concebidas para sustentarem as bases e os argumentos temáticos, encontram ecos nas propostas das exposições temporárias e nas atividades educacionais, que têm vocações singulares para o aprofundamento temático das ações de extroversão e para a transmissão de ideias entre gerações." (Bruno; Araújo, 2009, p.60)

As linhas de ação são:

- Centro de Referência - conexão em rede com fontes documentais e bibliográficas, ampliando o acesso a estas informações;

- Lugares da Memória - identificação dos espaços da memória localizados no Estado de São Paulo, expandindo o alcance preservacionista do Memorial;

- Coleta Regular de Testemunhos - registro de testemunhos de ex-presos políticos e de familiares de mortos e desaparecidos, para a construção de um banco de dados referencial sobre o DEOPS/SP;

- Exposições - apresentação de exposição de longa duração, cujo conceito gerador servirá de base para exibições temporárias com outros enfoques, proporcionando outros olhares sobre as questões relativas aos temas centrais do Memorial;

- Ação Educativa - construção de diálogos entre o discurso expositivo e o público por intermédio do desenvolvimento de processos formativos para 
educadores (ensino formal e não formal), da realização de visitas orientadas e da produção de materiais pedagógicos de apoio;

- Ação Cultural -promoção de eventos para a atualização das discussões sobre as práticas de controle e repressão, e as ações dos grupos de resistência durante regimes autoritários, e até mesmo democráticos, com abordagens multidisciplinares que possam renovar as interpretações sobre o passado recente. ${ }^{54}$

Por ocasião da elaboração do plano museológico (2010) foi diagnosticado que a instituição, com pouco mais de um ano da implantação inicial, necessitava de um plano de trabalho que promovesse a execução plena dos programas ligados à pesquisa e salvaguarda, começando pela Coleta Regular de Testemunhos Lugares da Memória, e destes dois, o fomento ao Centro de Referência. De lá pra cá, o Programa Lugares da Memória foi o primeiro a ganhar impulso. Em 2010 foram iniciadas as pesquisas, que deram origem a exposição "Lugares da Memória". Desde então a linha vem sendo implementada com financiamentos oriundos de projetos. O Programa Coleta Regular de Testemunhos ganhou incremento em 2012, e o Centro de Referência ainda aguarda a implementação efetiva. Pretende-se que, sobretudo os dois primeiros programas de pesquisa citados, sejam articulados a Ação Educativa e a Ação Cultural.

A criação do site do Memorial foi um grande passo para consolidação e difusão da instituição, inclusas aí a promoção das linhas de ação e todas as suas atividades. O Programa Lugares da Memória tem os resultados oriundos da primeira exposição temporária e que deram 'start' aos trabalhos do programa divulgados no site. Os demais programas estão aguardam desenvolvimento e futura veiculação em um site reformulado com mais opções de consulta ao visitante, sobretudo oferecendo acesso a resultados das pesquisas. A instituição dá passos para a consolidação dos programas de pesquisa, contando com uma destinação de verba em seu orçamento anual para manutenção de um pesquisador(a) temporário nas linhas Lugares da Memória e Coleta Regular de Testemunhos. Contudo, pelo volume de atividades, processos e informações a tratar o quadro de recursos humanos e de infraestrutura

\footnotetext{
${ }^{54}$ Com base no Plano museológico, Idem, p. 49.
} 
carecem de um incremento considerável e imprescindível para avanços maiores e em menos tempo ${ }^{55}$.

O Memorial da Resistência desenvolve contatos e parcerias com outros memoriais, instituições museológicas ou não. Contudo, prescinde de mais parcerias e apoios para desenvolver seus projetos, o que também depende de estrutura humana, técnica e de equipamentos. Entre parceiros já contatados estão a Coalização Internacional de Sítios de Consciência, as Comissões da Verdade - nacional e estadual, o Arquivo Público entre outros.

\subsection{3 - O Programa Coleta Regular de Testemunhos}

O Programa Coleta Regular de Testemunhos (PCRT) tem seu início no processo de implantação do projeto do Memorial da Resistência. Os testemunhos coletados dos ex-presos e ex-presas para coletar informações do edifício, das prisões e tantas outras deram base a concepção de todo projeto museográfico da exposição, e a vários de seus recursos, em especial a maquete que reconstitui o espaço carcerário, a cela 3 - uma reconstituição de uma cela durante a ditadura civil-militar e os depoimentos ou testemunhos que compõem o áudio, tema e cenarização da cela 4. Estes testemunhos (08 entrevistas individuais e 03 coletivas) são o embrião de formação do PCRT e, por conseguinte, do acervo em construção por esta instituição museológica. Das 11 entrevistas iniciais realizadas em 2008 (período de implantação da instituição), o programa já soma mais de 200 horas de gravação de testemunhos orais.

Após o período de implantação o Programa ficou temporariamente interrompido por falta de recursos financeiros, materiais e humanos. As "coletas" ou a realização de novas entrevistas reiniciaram no segundo semestre de 2012, com câmera não profissional e demais procedimentos em formação. Neste momento foram realizados os primeiros passos metodológicos, roteiros e gravações em formato individual, segundo a história oral. Foi a etapa de implantação de uma rotina de captação, registro, identificação de colaboradores etc. A obtenção de recursos como câmera,

\footnotetext{
${ }^{55}$ Somente em 2013 o Memorial conseguiu realizar a contratação de um profissional permanente para os programas de pesquisa, assim como de uma pesquisadora temporária para o programa de coleta de testemunhos. Atualmente existem duas pesquisadoras temporárias, uma dedicada ao programa Lugares da Memória e outra ao de Programa de testemunhos.
} 
iluminação e contratação de duas pesquisadoras possibilitou o incremento da produção e das rotinas a partir de 2013. Agora o Programa busca sua solidificação em termos metodológicos, conceituais, e técnicos, e um avanço no que tange o processamento técnico propriamente dito, a formatação final de manuais de procedimentos e uma imprescindível política institucional, posto que o material começa a ser procurado cada vez mais por diferentes segmentos do público externo. Todas essas etapas estão em fase de revisão, reelaboração e aprimoramento.

Uma das intenções do PCRT é constituir uma fonte geradora para todos os demais Programas ou Linhas de Ação da Instituição. Principalmente em relação ao programa de pesquisa Lugares da Memória, primeiro pela identificação de novos lugares com a contribuição dos testemunhos, e a partir de 2014 pela realização de coletas conjuntas que alimentam os dois programas, focadas em um lugar de memória em estágio de revisão e aprofundamento. Outra intenção é que ele forneça apoio na produção de entrevistas e conteúdos para exposições temporárias. O que também ocorrerá para reformulação da exposição de longa-duração prevista para 2015. A ainda uma prolongação "indireta" no Educativo através das Rodas de Conversa, que trazem um ex-preso político para contar sua experiência para grupos atendidos em visitas educativas, utilizando da narrativa e da memória em ação de extroversão.

O Programa está definido com o objetivo de “(...)ampliar o conhecimento sobre a história do Departamento Estadual de Ordem Política e Social - Deops/SP a partir do registro de testemunhos de ex presos e perseguidos políticos e de familiares de mortos e desaparecidos, bem como de outros cidadãos que trabalharam nesta instituição ou que por dever do ofício a frequentaram." (Relatório COC, Relatório de Atividades - 2009-2013, MRSP, 2014.). E produzir registros por meio de dois projetos:

"Projeto 1 - individual e em estúdio: O caráter individual desta ação tem como premissa que, embora esses cidadãos comunguem de um mesmo passado (e presente), tiveram atuações singulares nesse percurso e têm formas diferentes de tratar essas questões. Os testemunhos e o levantamento referencial de objetos testemunhos poderão ser utilizados posteriormente, através de empréstimos, para exposições temporárias e outros produtos já mencionados.." (Idem, 2014)

"Projeto 2 - coletivo e aberto ao público: Tem como objetivo o desenvolvimento de temas específicos, tais como o papel da Igreja, grupos de resistência, movimento estudantil, Anistia etc., por meio dos olhares e experiências dos cidadãos que tiveram uma atuação direta, intermediados por especialistas nesses temas. Diferente do Projeto 1, que se baseia na experiência individual do cidadão-testemunho, o Projeto 2 
tem como objetivo promover a construção participativa do conhecimento, além de possibilitar maior projeção do Memorial da Resistência como local de reflexão e de debates. Pelo caráter público, também possibilitará o registro das impressões e opiniões de pessoas com diferentes vivências sobre o período da Ditadura, desde os que tiveram uma participação mais direta como, também, daqueles que apenas assistiram aos acontecimentos." (Ibidem, 2014)

O projeto 1 realiza as atividades de captação de fevereiro a dezembro de acordo com metas trimestrais, com o cumprimento de 25 entrevistas por ano, número que tem aumentado significativamente com a incorporação de coletas ligadas às exposições temporárias, projetos específicos e outras demandas. O Projeto 2 teve suas primeiras captações dentro dos Sábados Resistentes, ligados a Rememoração dos 50 anos do golpe civil-militar, durante o mês de abril de 2014. Foram realizadas três coletas públicas e há mais uma prevista para o segundo semestre de 2014 (a meta mínima é de 2 coletas ao ano, uma por semestre). Em números, o programa realizou 93 entrevistas, com participação de 88 entrevistados ${ }^{56}$.

Uma vez postos o alargamento do conceito e uso do patrimônio cultural, e os novos desafios colocados aos museus, impõe-se a constante necessidade de revisão e reflexão de suas práticas, para se chegar a novas formas de ação. Neste sentido, o propósito da pesquisa é identificar essas formas de fazer (dos processos museológicos), e como elas chegam ao público.

Para tanto foi escolhido um grupo de fontes que fornecem dados sobre o processo de construção (a transformação do fato museológico ao fenômeno e ao processo museológico), e índices de resultados deste mesmo processo.

Trata-se neste caso de uma natureza diferente de fato e fenômeno, pois não estão alicerçados na reunião de uma coleção material pré-existente, mas na construção de uma coleção a partir de indicadores de memória, tomada aqui como um patrimônio intangível em processo de musealização.

Por isso, o foco de análise centra-se no Programa Coleta Regular de Testemunhos do Memorial da Resistência de São Paulo: desde como ele foi idealizado e elaborado como uma das linhas programáticas do museu, à sua forma de extroversão e comunicação ao público. As fontes relacionam-se e refletem os pontos acima arrolados.

\footnotetext{
56 Dados atualizados até julho de 2014 - baliza para coleta de dados do Programa Coleta Regular de Testemunhos.
} 
Essa investigação pretende fornecer dados novos que permitam 0 desenvolvimento e contínua renovação do patrimônio em questão e de sua musealização. Tanto para a valorização + conhecimento deste patrimônio, como também, de que maneiras ele pode ser potencializado pelo museu, dentro da natureza particular de suas ações, quais sejam a salvaguarda e a comunicação de bens culturais. Vislumbra-se que estas informações contribuam à implementação de ações de revitalização de memórias/tradições/saberes, os transformando em bens culturais e em vetores de desenvolvimento.

Por hora, verifica-se que no lócus em questão, a principal forma de apresentação e extroversão do patrimônio constituído é a exposição de longa duração em vigor. Esta é a principal via de interação e contato dos públicos com o patrimônio musealizado pelo Memorial da Resistência. É também a via de troca desta instituição museológica com os públicos que recebe. Vê-se assim na exposição um meio de comunicação e interação privilegiado, e ao alcance para análise do problema em estudo. A interlocução da exposição com o público tem sido captado por alguns instrumentos utilizados pela instituição, e que serão tomados nesta pesquisa como fontes. Fica claro que a exposição tem sido o principal meio de apresentação do tema e bem cultural alvo desta instituição, bem como sua proposta de problematização dos mesmos. Caberá nos tópicos que seguirão verificar a forma como o Programa Coleta Regular de Testemunhos é desempenhado, como ele chega ao público, que correspondem no modo como ele se relaciona com a exposição de longa duração e com os demais programas da instituição.

\section{3 - O Conceito de Memorial}

Do lado conceitual, os museus já foram largamente definidos em terminologia e funções, assim como o estabelecimento de novos tipos de museus também faz parte do cenário. Existem muitas definições atribuídas pelos museólogos, contudo a definição oficialmente aceita e difundida resta a apresentada pelo ICOM, por seu estatuto de 2007:

\footnotetext{
"Os museus são instituições permanentes, sem fins lucrativos, ao serviço da sociedade e do seu desenvolvimento, abertas ao público, que adquirem, preservam, pesquisam, comunicam e expõem, para fins de
} 
estudo, educação e lazer, os testemunhos materiais e imateriais dos povos e seus ambientes."

Os museus são definidos em versões mais atualizadas como uma instituição ou lugar, geralmente concebido para proceder a seleção, estudo e apresentação de testemunhos materiais e imateriais do homem e seu ambiente (DESVALLÉES et MAIRESSE, 2010) $)^{58}$.

Novos conceitos entram no campo dos museus que pode também ser visto como um "Lieux de Mémoire" (Nora, 1984 ;Pinna, 2003), como lugares de abordagens múltiplas na sua forma de ser, de gestão, conteúdo, ou a presença ou não de coleções. As denominações passam por ecomuseu, museu comunitário, museu de território, museus virtuais ou cybermuseus.

Ainda que todos os museus tragam a memória como conteúdo subjacente, aos Memoriais aufere-se um peso muito maior do significado de memória a ser trabalhado neste espaço patrimonial. Os Memoriais tratam de memórias específicas, de relevância e interesse social, mas com a função determinante de rememorar seu tema de composição. Normalmente, é condição que tais temas nasçam de conflitos sociais, políticos, culturais, religiosos, armados, que incluem violações aos direitos humanos. Há também os memoriais dedicados a pessoas, sejam elas tomadas em grupo ou a um indivíduo de notoriedade social em particular.

É cada vez mais notório que os Memoriais exercem papel caracterizado especialmente pela atuação junto a comunidades e grupos afetados de um lado, e de outro, voltados à educação política, à educação em direitos humanos e ao direito a memória. O que está em jogo é a valoração da memória de um ou mais grupos, e a problematização de determinado tema ou fato histórico ligado a esta memória.

Memoriais podem ou não ter coleções de objetos ou acervos materiais. Como muitos museus sem acervos, os memoriais se baseiam na própria materialidade de um lugar de memória e na construção de acervos a partir de seu trabalho de

\footnotetext{
${ }^{57}$ Do original em francês « le musée est une institution permanente sans but lucratif, au service de la société et de son développement, ouverte au public, qui acquiert, conserve, étudie, expose et transmet le patrimoine matériel et immatériel de l'humanité et de son environnement à des fins d'études, d'éducation et de délectation ». Estatuto do International Council of Museums (ICOM), 2007 e Código de Ética para Museus. Versão Lusófona, 2010. Definição também exposta em POULOT, Dominique. Musée et museologia. Paris. La Découverte, «Repères », 2005.

${ }^{58}$ Do original em francês. "I'institution que l'établissement ou le lieu généralement conçu pour procéder à la sélection, l'étude et la présentation de témoins matériels et immatériels de l'Homme et de son environnement." Grifo nosso.
} 
musealização. É claro que a memória é sempre transmitida por meios materiais. Mas seu cerne maior é a musealização de patrimônios imateriais ou intangíveis, considerando-se seu conteúdo maior, a memória, o bem cultural e patrimonial a ser preservado.

Memória está no cerne da palavra memorial, que pela mesma raiz, traz a função de rememorar algo ou alguém. É comum ver que na busca de uma definição, recorre-se à etimologia da palavra memorial (do latim "memorialis", onde "memo" significa recordar e "al" significa pertencer ${ }^{59}$ ), e a definição mais comum refere-se ao ato ou circunstância de recordar a vida e feitos de um personagem famoso ${ }^{60}$. Esta definição causa muitas confusões, e como bem aponta Jorge Barcellos, uma "ambiguidade norteia o conceito senso comum a partir do qual foram construídas tais instituições. No meio campo entre museu e centro cultural, o memorial não tem uma identidade definida conceitualmente, aparecendo e diluindo suas funções ao sabor das administrações." (BARCELLOS,1999, p.6). Pois o Memorial, enquanto lugar de representação de uma memória coletiva, que representa ou guarda uma memória social/coletiva tratada como um patrimônio, não possui uma definição própria. Tido normalmente como um museu, seus usos e formas podem ser diversos, passando pela denominação de monumentos, erigidos com intuito de tributo, láurea ou homenagem, muitas vezes póstuma, direcionadas a fatos e pessoas. Já de acordo com Prado e Soligo (2005; p. 6), “(...) para produzir um Memorial é necessário um conhecimento prévio: "[...] das condições em que estão circunscritas as lembranças, assim como os acontecimentos e personagens que predominaram segundo as escolhas feitas [...]". Pois o discurso expositivo que este vai adotar diante das ações, idéias, impressões e conhecimento da pessoa ou instituição homenageada é que vai definir o acervo a ser utilizado em uma exposição - temporária ou permanente." [PRADO e SOLIGO, 2005; apud SANTOS, 2010, p.27]

Enquanto instituição preservacionista os Memoriais prescindem de uma definição específica que o delimite dentre as demais instituições museais, ainda que ele esteja abarcado pela definição geral, e mais comumente adotada de museus, expressa pelo ICOM. Neste ponto, concordamos ainda com Barcellos, ao assinalar

\footnotetext{
${ }^{59}$ Etimologia da palavra Memorial in Gramaticas.net (http://www.gramaticas.net/2013/04/etimologiade-memorial.html).

60 Do verbete Memorial: "Scritto o nota esplicativa di circostanze e di fatti de gnidiessere ricordati; insiemedi memorie riguardanti la vita e l'attività di um personaggio famoso: il m. di Yalta. il Sabatini Coletti. Dizionario de la lingua Itiana. http://dizionari.corriere.it/dizionario_italiano/M/memoriale.shtml
} 
que "a memória tem sido objeto de cada vez mais iniciativas e a criação de Memoriais uma de suas práticas." (BARCELLOS, 1999, p.6).

Estes "museus-memoriais" ou "memoriais-museus" recebem várias outras denominações conforme seu contexto de localização e criação, e podem ser Museus de Memória, Sitos de Consciência, Museus de Direitos Humanos, Museus de Resistência $^{61}$, ou ainda Museus de Paz ou Museus Antiguerra ${ }^{62}$. Na maioria dos casos, são espaços com função cultural e seu objetivo maior é preservar e divulgar uma determinada memória. Sobretudo, aqueles localizados em sítios históricos. Sua maior projeção ganhou lugar com os Museus do Holocausto na Alemanha e em outros pontos da Europa, bem como pelos museus de Holocausto criados nos Estados Unidos. Os locais que assistiram a perseguições que qualquer ordem, opressão e crimes contra a liberdade, democracia e condições humanas têm recebido, desde a segunda metade do século $\mathrm{XX}$, iniciativas museológicas em torno dos eventos históricos que lhe são relacionados.

A proliferação de Memoriais pelo mundo mostra sua importância e também os conteúdos que lhe são atribuídos. Como já foi dito, muitos Memoriais foram criados em homenagem a figuras de destaque, e constituídos por tudo de que faça alusão a biografia e trajetória do homenageado. Entre eles podemos citar O Lincoln Memorial (Washington DC), o Memorial F.M. Dostoievski (São Petersburgo); Memorial John F. Kennedy (EUA), ou o Memorial em homenagem a Diana Spencer (Lady Di), conhecido como museu das lágrimas (Inglaterra).

Os temas se expandem, assim como o caráter dessas instituições: Sitio Histórico Nacional Martin Luther King, Museo Nacional de Derechos Civiles, Museu da Paz de Hiroxima e o Peace Osaka, US Holocaust Memorial Museum; Mémorial de la Shoa; a Casa de Anne Frank, a Fundação Aristides de Sousa Mendes e o Museu da República e Resistência Lisboa são exemplos.

Para os "museus de resistência" encontramos representações cada vez mais crescentes. No plano internacional podemos citar Arquivo \& Museu da Resistência Timorense (Dili, Timor Leste); o Musée de la Résistance Nationale, com sede em Paris (Champigny-sur-Marne) e 7 núcleos dispersos pelo país (em Bourges, Champigny,

\footnotetext{
${ }^{61}$ Fala-se ainda em Museus de Consciência. Ver mais sobre lugares de memória da ditadura em VALLE, 2012.

${ }^{62}$ Como apontado por Carlos Beltrão do Valle, essas são outras designações para os museus de Consciencia. O autor cita que o primeiro museu dedicado a Paz surgiu em 1902, Lucerna, Suiça, chamado Museu Internacional de Gerra e Paz, por iniciativa do pacifista holandês jan Bloch. A referência para esta informação é o trabalho de mestrado de Marcelo Souza.
} 
Châteaubriant, Givors, Montluçon, Varennes-Vauzelles e Nice); o Verzetsmuseum (Museu da Resistência), e Museu da Tortura - ambos na Holanda. Outra experiência marcante é a Organização Coalizão Internacional de Sítios de Consciência, entidade que criou uma coligação de Sitios de Consciência (Sites of Conscience) ${ }^{63}$, em todos os continentes, e congrega, em especial, Museus da Resistência nos continentes Africano, Ásia e América Latina. Constitui uma rede mundial de sítios de consciência, com expressivas redes regionais.

$\mathrm{Na}$ América do Sul merece destaque a iniciativa empreendida pelo Memoria Abierta - Acción Coordinada de Organizaciones argentinas de Derechos Humanos (Argentina), a Corporación Parque por la Paz Villa Grimaldi (Chile), o Museo Memorial de la Resistencia Dominicana (República Dominicana), o Museo de la Memoria Centro Cultural Museo de la Memoria (MUME, Uruguai), o Museo de las Memorias Dictadura y Derechos Humanos (Paraguai), e Museu da Solidariedade Salvador Allende (Santiago do Chile) ${ }^{64}$.

A América Latina vive um contexto particular, iniciado pelas reconquistas democráticas em todos os países que tiveram governos ditatoriais e/ou totalitários, assim que em cada país foram instauradas leis de acesso e direito à verdade, e de programas de justiça reparadora a vítimas do chamado terrorismo de estado. Nesta perspectiva, o tema da ditadura, assim como a reivindicação por direitos e também lugares que Ihe são alusivos vem em um crescente. No Brasil, Chile e Argentina os lugares que serviram como prisões, tribunais, centros de tortura. E outros como edifícios, casas, propriedades rurais, faculdades, etc são reivindicados como espaços simbólicos da repressão e da resistência. Tidos e utilizados como lugares de memória, esses locais são reutilizados para a reconstrução da memória da ditadura. Tais lugares materializam a evocação dessa memória silenciada, e fazem parte de lutas atuais por justiça, verdade e direitos humanos ${ }^{65}$. Lembrando que a preservação da memória é vista hoje como uma garantia de direito a verdade, o que significa uma garantia ampla dos direitos humanos, por todos os meios jurídicos que trabalham com

\footnotetext{
63 Informações a partir do site http://www.sitesofconscience.org .

${ }^{64}$ Está em curso um inventário de memoriais, pretende-se apresentar como um dos resultados finais da pesquisa para esta dissertação.

65 O Primeiro Encontro de Museus da Memória do Mercosul foi realizado em abril de 2008 em Montevidéu com intuito de cruzar as experiências em torno da memória de repressão pelo Estado dos países do Mercosul, reuniu pessoas e entidades de Uruguai, Argentina, Paraguai, Brasil, Peru e Chile. Participaram Museu de Arte e Memória de La Plata (na Argentina), O parque pela paz Villa Grimaldi (Chile), o Museu das Memórias do Paraguai e o Centro de Informação para a Memória Coletiva do Peru. "Museus sobre a memória do Mercosul se encontram pela 1a vez". Portal iG, Seção "Último Segundo", Educação, Agência Ansa, 02/04/2008. http://ultimosegundo.ig.com.br/educacao/museus-sobre-amemoria-do-mercosul-se-encontram-pela-1-vez/n1237682154881.html
} 
causas de violação de direitos humanos, notadamente a chamada Justiça de Transição e Justiça de Reparação. Os atos de memória seriam, por conseguinte formas de reconhecimento dos crimes a uma garantia para a não violação das repetições (PETRUS, 2010) ${ }^{66}$.

Outra forte iniciativa na América Latina corresponde à sinalização de Lugares da Memória. Artistas contemporâneos têm sido chamados a fazer parte dos trabalhos de reconstituição dessas memórias por meio das artes plásticas e de fotografias, que constituem memoriais a céu aberto ou parques inteiros como é o caso do Parque de La Memoria. O Chile é referência nesta ação e na Argentina entre os mais conhecidos estão a Praça de Maio e a ESMA (Escola de Mecânica da Marinha) este transformado em um Museu da Memória ${ }^{67}$.

Porque queremos um lugar de memória ou museu de memória? Precisamos dele?

Memoriais são novas formas de trabalhar e mediar a herança cultural. Antes mausoléus, monumentos e museus serviam para rememorar e glorificar o poder. Agora são lugares com perspectiva social mais abrangente. Representam locais de divulgação de fatos e versões ligados aos vencidos ou oprimidos da história. Outros lados da sociedade ganham lugar de homenagem e espaço para expor suas memórias, lugar de lembrar, honrar mortos e vitimas, e recuperar verdades históricas. A muitos não interessa ver passados revelados. Essa memória é incômoda, e se está na condição de patrimônio é então um patrimônio incômodo.

Como patrimonializar a memória? Como realizar a patrimonialização de uma memória indesejável, desagradável e traumática? Como musealizar lugares invisíveis?

Essas respostas estão em construção. Um pedaço desta resposta é desvelada a cada dia, em cada um dos lugares de memória, de memoriais, ou sítios de consciência. O que já se sabe é que o tema exige múltiplos enfoques. Que é um lugar que deve estar a serviço das vitimas, familiares das vitimas e sociedade de modo geral. Essas instituições devem evidenciar que este tema é mais uma entre as demais perspectivas culturais e históricas presente neste local, grupo, país. Ainda que se trate de um tema extremamente sensível, deve se capacitar e definir o que irá oferecer em

\footnotetext{
${ }^{66}$ Assunto amplamente explorado em Revista Anistia Política e Justiça de Transição - Ministério da Justiça - N. 3. Brasília: Ministério da Justiça, jan./jun. 2010.

${ }^{67}$ Sobre monumentos de guerra em memorian e os monumentos de arte publica ver artigo de ABREU, JOSÉ GUILHERME. Arte pública e lugares de memória. Revista da Faculdade de Letras, CIÊNCIAS E TÉCNICAS DO PATRIMÓNIO, Porto, 2005. I Série vol. IV, pp. 215-234
} 
reflexão histórica. E como convencer a sociedade a tratar de temas tabus. Sobretudo porque seu público maior são as gerações atuais.

Se "o como fazer" está por descobrir, o caminho a trilhar tem nas linhas expostas alguns possíveis apontamentos do que se pretende chegar a realizar. Alíneas que também ajudam a transformar o "mito" do "Brasil pais sem memória", ressaltando o papel singular que os Memoriais desempenham para quebrar esse e muitos outros tabus. Os Memoriais tem um potencial social privilegiado, que aumentam em potência uma contribuição para transformar pré-conceitos, discriminações e intolerâncias.

Há ainda que se diferenciar o papel dos museus históricos e dos memoriais. Ambos trabalham com temas históricos, todavia seus perfis e formas de atuação seguem caminhos diferenciados. Em comum, eles carregam a herança dos museus vistos como repositórios de memória. Esta memória, como já vem sendo largamente ilustrado, apresentam-se nos mesmos moldes dos museus e narrativas apresentadas no século XIX. Seus conteúdos, formato e discursos proporcionam mais distância que reconhecimento. Eles uniformizam diferenças, e não respondem a ambivalência da sociedade, que sabe questionar, mas deixa-se dominar ao mesmo tempo pelos ditames da sociedade de consumo.

Entre discursos e práticas nos museus muito já foi incluído (pessoas, identidades, novos discursos), assim como muito ainda não foi alterado. Entre avanços e recuos, alguns casos de museus podem nos ajudar a pensar em caminhos de (re) construção desses espaços em direção a uma condição de fórum, que dialogue com a sociedade e a convide à reflexão, onde uma reinvenção das ágoras seria possível. Alguns casos de museus e estudos nos dão pistas às questões que temos arrolado. $E$ é este o exercício que se propõe no presente trabalho.

\section{4 - Os Memoriais na paisagem museológica brasileira}

O Brasil segue o mesmo quadro explicitado para os Memoriais do mundo. Um dado interessante, especialmente em São Paulo, é o fato de ser muito comum quando as pessoas ouvem falar em memorial remeterem-se diretamente ao Memorial da América Latina. Concebido pelo arquiteto Oscar Niemeyer, é um dos maiores 
exemplos de Memorial, voltado ao sentido e função de centro cultural, e agrega funções de museu, biblioteca, galeria, centro de convenções, etc ${ }^{68}$.

Entre todos os casos, o mais marcante e de maior impacto em nosso presente são os memoriais dedicados aos regimes ditatoriais ocorridos no Brasil. Seu surgimento e incremento deve-se a atuação da Comissão da Verdade Nacional, das Comissões da Verdade instaladas em diversos Estados da federação, que têm elas mesmas incluído entre as formas de reparação, do direito a memória e a verdade, processos de tomada de locais de repressão para preservação e transformação em local de memória, seja por projetos de sinalização desses lugares de memória, seja pela criação de memoriais nesses espaços. Todo esse processo está inserido no quadro maior do III Plano Nacional de Direitos Humanos (PNDH 3), que instala as Comissões da Verdade, dentro da atuação da Justiça Transicional, ainda que a Lei da Anistia, como aplicado no Brasil, impeça a punição de torturadores.

Dos conhecidos, alguns foram inaugurados e estão em pleno funcionamento. Outros ainda não totalmente implementados ainda estão em processo de desenvolvimento. É de recente monta o anúncio de mais locais que vão sendo incorporados ao mapa da memória ditatorial ${ }^{69}$.

Em São Paulo, estão em processo de patrimonialização os antigos DOI-CODI e Auditoria da Justiça Militar. O primeiro obteve pedido de tombamento do edifício, junto ao Condephaat (Conselho de Defesa do Patrimônio Histórico, Arqueológico, Artístico e Turístico $^{70}$. O pedido foi aprovado em 27/01/2014 e abre espaço para tentativa de criação de um novo espaço de memória. Situa-se na Rua Tutóia no bairro de Vila Mariana e ainda mantém-se aberto com funções policiais, onde abriga o 36.0 Distrito

\footnotetext{
${ }^{68}$ Segundo pesquisa de Jorge Barcellos, realizada de novembro de 1997 a novembro de 1998, um levantamento de memoriais e noticias de memórias em jornais aponta a forma confusa como eles são vistos pelo público. E para memoriais personalistas ele aponta em território nacional a existência do Palácio de Tábuas, também conhecido por Catete, que homenageia Juscelino Kubitschek, e o Memorial da Câmara de Porto, com perfil de memória institucional legislativa. Barcellos, op. Cit.

${ }^{69}$ Existe um memorial com 0 nome de Memorial da Resistência em Mossoró (RN), contudo seu conteúdo reflete a história da cangaço, em especial àqueles que resistiram nesta cidade, a invasão de Lampião e seu bando. 0 memorial possui três edifícios que contam contexto histórico da região e do cangaço, além de contar a história de Virgulino e seu bando. 0 memorial não tem web site. Sua fonte mais completa é página na wikipidiahttp://pt.wikipedia.org/wiki/Memorial da Resist\%C3\%AAncia Mossoroense. Há também muitos blogs que comentam o local.

${ }^{70}$ Encaminhado pelo jornalista e ex-preso político Ivan Akselrud Seixas, com o apoio do Fórum de expresos, do Conselho Estadual de Defesa dos Direitos da Pessoa Humana (CONDEPE), da Comissão de Familiares de Mortos e Desaparecidos, e também pelo Grupo Tortura Nunca Mais-SP.
} 
Policial de Vila Mariana. O segundo, já está em fase implantação por meio da captação de recursos para execução do projeto de criação do Memorial da Luta pela Justiça, a funcionar em um casarão histórico, sede da 2. ${ }^{\text {a }}$ Auditoria da Justiça Militar, na Rua Brigadeiro Luís Antônio.

Ainda em nível local, existe o Memorial da Democracia em Recife, Pernambuco, anunciado em 31 de março de 1998. Quando do anúncio de sua criação, uma campanha pública para coleta de objetos, documentos, fotografias, cartas, depoimentos entre outros foi lançada. O projeto foi levado a efeito em parceria do Movimento Tortura Nunca Mais/PE, em parceria com o Governo do Estado. A defesa é de que o lugar seria um ponto vivo "de renovação das vidas dos militantes e de formação de novos lutadores", diferenciando o memorial de um museu ${ }^{71}$. Contudo, tem-se noticia de que este memorial permanece na fase de projeto. Outro caso local é a recente inauguração do Memorial da Resistência de Fortaleza, projeto conjunto de diversas entidades com a prefeitura municipal.

Uma matéria mais recente dá conta que o Memorial da Democracia do Recife tem apoios de governo estadual e federal e o liceu de artes e ofícios será sua sede. Este memorial também fará parte da Rota da Ditadura - "uma lista de locais históricos da capital pernambucana que têm ligações com a repressão no regime militar, entre 1964 e 1985."72 E que está exposta no guia turístico Recife Lugar de Memória. Já existe uma escultura, de Demétrio Albuquerque, próxima a antiga sede do Dops de Pernambuco $^{73}$.

Existe também projeto para construção de um Memorial Marighella na Bahia, provavelmente sediado no complexo histórico do Pelourinho. Com vistas a sua implantação, um seminário foi organizado em Salvador pelo Governo do Estado, através da Secretaria de Cultura (Secult/BA), o "Seminário Memorial da Resistência Carlos Marighella: reflexões e subsídios ao processo de implantação". A intenção foi reunir militantes e representantes de entidades, para discutir projeto de implantação de

\footnotetext{
${ }^{71}$ Fala de Amparo Araújo, líder do Movimento Tortura Nunca Mais /PE. "Luta contra ditadura ganha memorial", Jornal do Commercio - Recife, 31 de março de 1998 . In: http://www2.uol.com.br/JC/_1998/3103/po3103j.htm

72 'Rotas da Ditadura' entram no mapa do País. ROLDÃO ARRUDA - O Estado de S.Paulo. 18 de agosto de 2013. In: estadao.com. br. Consulta em 18/08/2013.

${ }^{73}$ Segundo a mesma matéria, Recife foi uma das primeiras cidades a inaugurar um monumento para lembrar as vítimas da ditadura, em 1993, e é uma das que mais investem na memória do período. Idem, OESP, 18/08/2013.
} 
um memorial em defesa da democracia na Bahia ${ }^{74}$. O projeto prevê que ele seja instalado nos casarões 28 e 30 da Rua João de Deus, no Pelourinho, e a previsão de abertura é até o final de $2014 .^{75}$

Em outro formato, o de um museu de percurso, a secretaria Estadual de Justiça. Cidadania e Direitos Humanos do Paraná realiza o projeto "Caminhos da Resistência", cujo objetivo é identificar e sinalizar locais e pessoas que marcaram o período da ditadura civil-militar. No que tange os locais é de interesse mapear os locais onde ocorreram violações de direitos humanos e também lutas populares por liberdade e democracia. A Comissão de Anistia do Ministério da Justiça já inaugurou alguns pontos dos "Caminhos da Resistência", marcados em vários pontos da capital paranaense.

No mesmo sentido, outra iniciativa é idealizada pelo governo federal, chamada Trilha da Anistia. Ela comportará a abertura de 10 pequenos memoriais em diferentes cidades do país, levado a efeito pela Comissão da Anistia, vinculada à pasta da Justiça. O primeiro foi instalado em Minas Gerais, Belo Horizonte, com a instalação de uma placa com nomes dos mortos e desaparecidos em frente ao antigo DOPS estadual. O segundo foi implementado em Curitiba (em praça onde funcionou o comitê paranaense da luta pela anistia), e o terceiro tem previsão de ocorrer na Cinelândia, Rio de Janeiro (em memória de militares que se opuseram ao golpe militar de 1964). Os próximos locais previstos são Fortaleza, São Paulo e Goiânia. Segundo a matéria de $\mathrm{O}$ Estado de São Paulo, "O projeto dá continuidade à série denominada Pessoas Imprescindíveis, desenvolvida pela Secretaria de Direitos Humanos durante o governo Luiz Inácio Lula da Silva. Ela resultou na instalação de 27 memoriais - a maioria deles constituídos por placas com nomes de cidadãos mortos por resistirem à ditadura."76

O Memorial da Anistia, a ser instalado no antigo prédio da Faculdade de Filosofia e Ciências Humanas de Universidade Federal de Minas Gerais, em Belo Horizonte, também é projeto e aporte do governo federal, ainda sem previsão concreta de inauguração.

\footnotetext{
74 "Memorial da Resistência Carlos Marighella em Salvador." Portal Secult BA. Publicação: 23/05/13, última atualização: 27/05/13. http://www.cultura.ba.gov.br/2013/05/23/memorial-da-resistenciacarlos-marighella-em-salvador/

75 "Salvador vai ganhar Memorial da Resistência no Centro Histórico". Jornal Correio. 02.06.2013 http://www.correio24horas.com.br/noticias/detalhes/detalhes-1/artigo/salvador-vai-ganhar-memorialda-resistencia-no-centro-historico/

${ }^{76}$ Ibidem. OESP, 18/08/2013.
} 
Nesse contexto, o Memorial da Resistência de São Paulo ocupa a posição de primeiro sítio histórico recuperado e transformado em um Memorial, voltado à memória da ditadura no Brasil e à missão de educar para os direitos humanos. Hoje sua experiência pioneira serve de modelo e atua de forma consultiva em vários memoriais em vias de implantação. É extremamente positivo que os memoriais surjam e se multipliquem por todo o país. Em maio de 2014 foi promulgada a e sancionado o tombamento do Doi-Codi em São Paulo. Espera-se que ele se torne um memorial, medida ainda sem definição. E aguarda-se também que o Memorial da Resistência de São Paulo alcance sua ampliação em todos os sentidos, a começar pelo espaço físico.

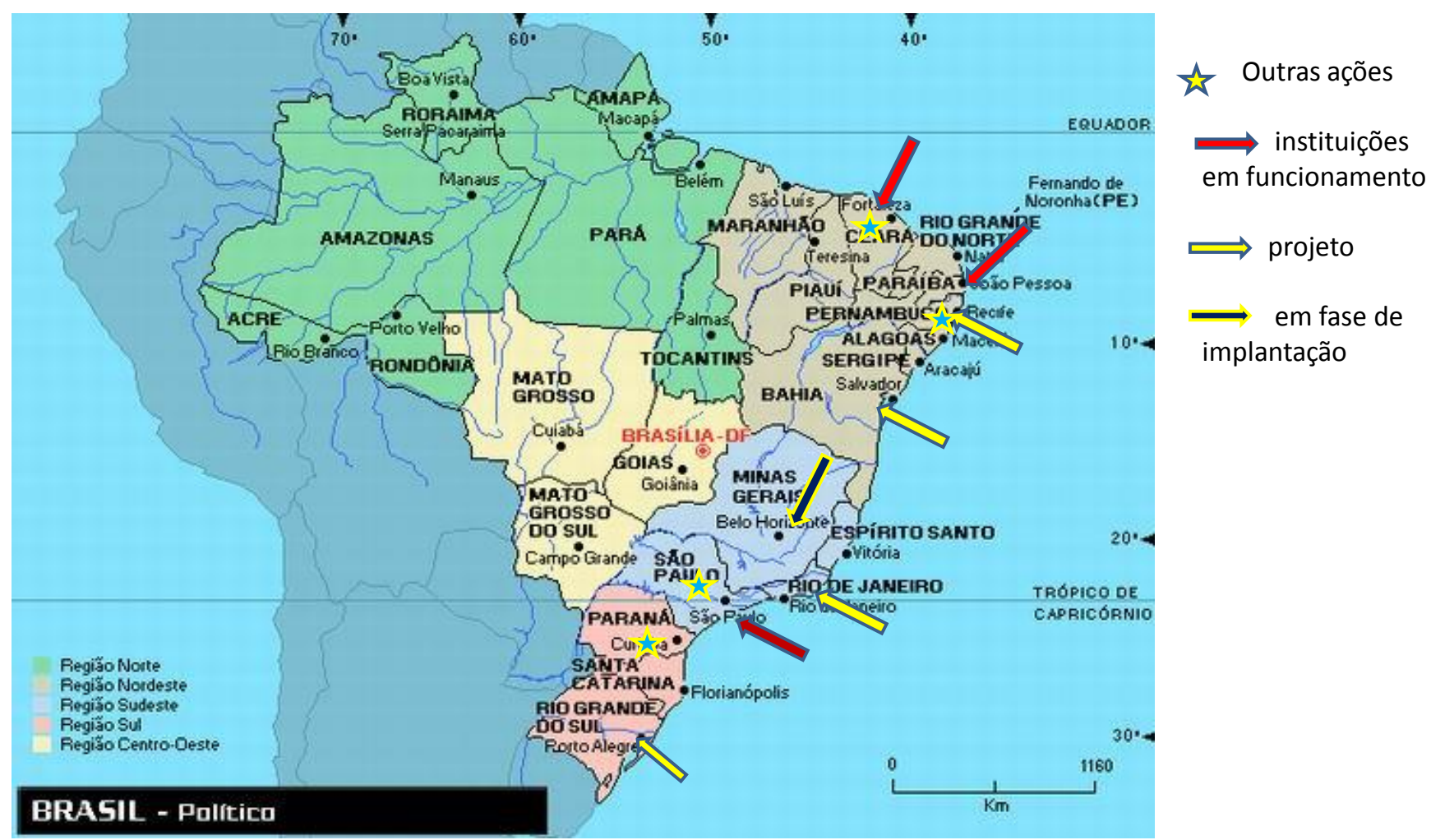

Situação dos Memoriais distribuídos geograficamente e por fase desenvolvimento. 


\section{Capitulo 3}

\section{A experimentação: construção da pesquisa e do conhecimento acerca do imaterial em museus}

A problemática deste trabalho consiste em compreender a relação entre 0 patrimônio cultural imaterial/intangível e a preservação museal, ou como o imaterial está inserido nos museus.

Muitas podem ser as formas de abordar esta questão. A escolhida por nós parte do processo de musealização, do plano museológico, do projeto de gestão e programas de uma instituição museal, privilegiando dados gerados em avaliações de público produzidas por essa instituição. Ao longo do processo de investigação percebemos que dados transversais muito significativos eram produzidos pelo próprio processo de formação de acervo da instituição estudada. Falamos aqui de dados presentes nas entrevistas produzidas pelo programa em foco de análise (o PCRT), dado como eixo central de continuidade do conceito gerador do museu.

Estes dados versam sobre a compreensão e visão dos atores sociais ligados ao bem cultural em questão, a saber: as memórias de militantes e outros que protagonizaram ações de resistência à ditadura civil-militar. Nestes dados percebemos como estes protagonistas participam deste processo de musealização, da construção de um acervo de testemunhos orais, relação e papel que atribuem a este museu. Consideramos relevante incluir tais informações na construção empírica, tendo em vista que, ao falarmos de patrimônio cultural imaterial, uma análise mais completa só pode ser atingida quando incluímos olhares sob os autores do bem cultural musealizado. Pretende-se, assim, perscrutar o olhar museológico construído e perceber como os atores sociais estão presentes nesse processo.

A razão está em reconhecer o papel fundamental dos autores ou detentores do bem cultural seja para sua existência, reconhecimento ou continuidade. O patrimônio imaterial abrange a legitimação de uma manifestação cultural, que depende de seu autor e detentor para que ela possa ser transmitida. Propriedade esta oriunda de sua natureza enraizada em uma dinâmica viva, cotidiana, em pleno uso e movimento. Outra razão é o entendimento de que o intuito de preservar só está completo se considerados os autores das práticas ou bem cultural em todas as etapas da cadeia preservacionista. O imaterial implica também em oferecer espaço para autorepresentação e para as identidades. Portanto, é necessário averiguar se o processo 
de musealização inclui os detentores do bem cultural. Esta visão se complementa para além do ponto de vista institucional, com a visão destes atores sociais, como enxergam o museu e como se dá sua relação com o mesmo. Este nível de cruzamento de informações permite perceber se eles sentem-se representados e como se dá essa representação, em qual nível e de que formas ou meios.

No caso do MRSP o processo de identificação do bem cultural imaterial ocorre pelo reconhecimento, coleta e registro de testemunhos de pessoas que viveram os períodos ditatoriais brasileiros, com enfoque principal nos ex-presos e ex-presas políticas, sobretudo aqueles(as) que passaram em qualquer situação pelo Deops/SP, e/ou foram lá mantidos(as) em cárcere. Ninguém além, ou mais que eles, têm a legitimidade e o saber relacionados aos fatos e eventos ocorridos durante a severa repressão política levada a efeito pelo Estado brasileiro. Podem falar sobre a história dos movimentos sociais e políticos, e sem precedentes, das memórias dolorosas por terem sofrido violações graves de direitos de toda ordem, cujo ápice está na tortura. No presente, eles são as únicas testemunhas que podem relatar fatos, pessoas e lugares, sobretudo sobre os locais onde foram presos e torturados das mais diversas formas.

Assim, os instrumentos e fontes tentam responder as indagações levantadas no processo de musealização, segundo o modelo:

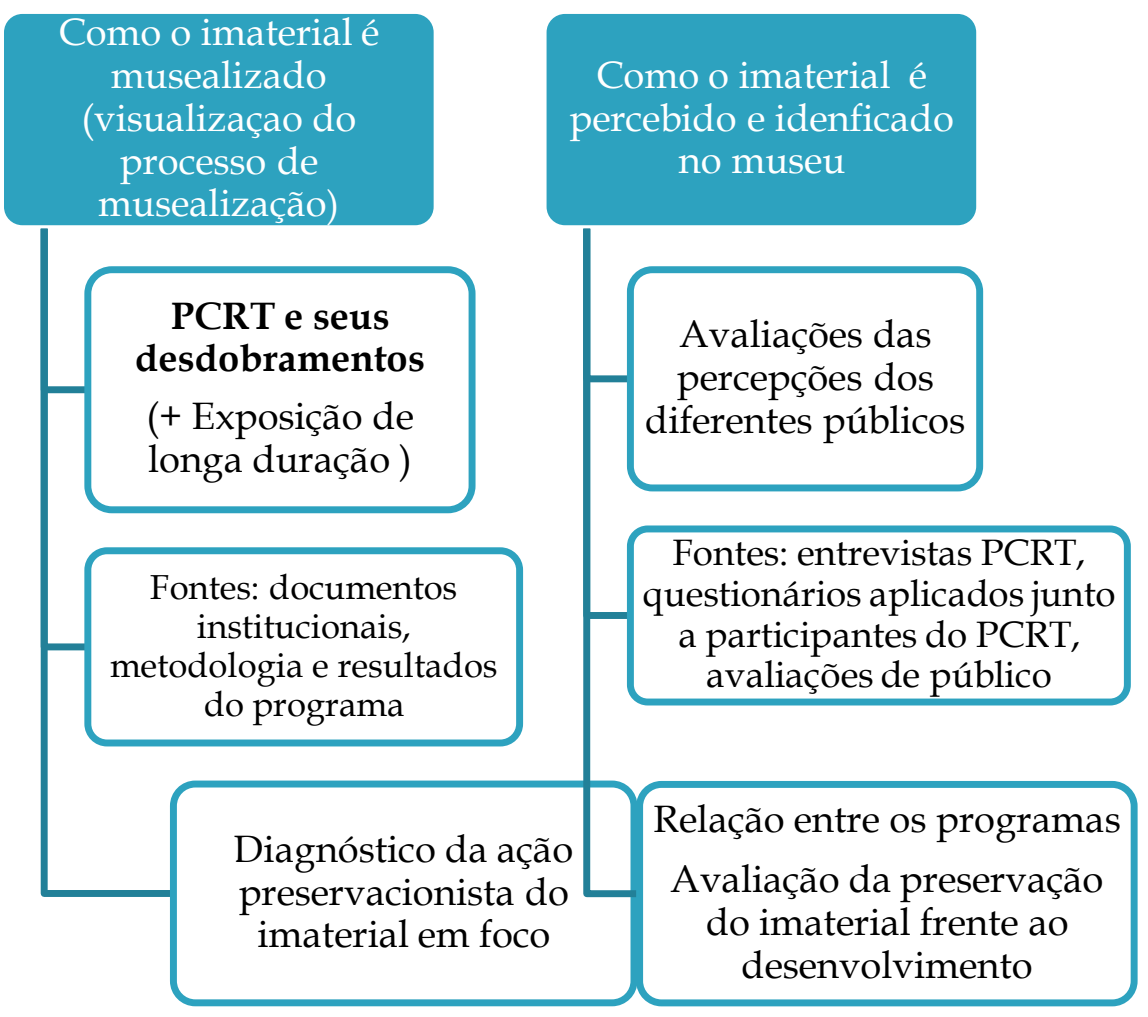


O arrolado acima pretende ser respondido na análise e interpretação da execução do Programa Coleta Regular de Testemunhos. Dos produtos, as entrevistas geradas nesse programa, extraímos as impressões de ex-presos sobre sua participação em ações do museu, bem como sua relevância. Completamos essas impressões com um questionário aplicado a alguns ex-presos políticos durante o período de pesquisa para obter mais dados da leitura dos ex-presos sobre sua participação nos processo do museu.

Como se falou de interface com o processo de musealização, e que ele está centralizado na exposição de longa duração, utilizamos as avaliações de público institucionais para ajudar a compreender e metrizar a presença do imaterial no referido processo. Dadas as relações com a oralidade, utilizada ao mesmo tempo como referência patrimonial (relatos, memórias e testemunhos), e metodologia para sua musealização, estes dados poderão dizer se o processo se efetiva com sucesso, possibilitando a averiguação de nossas hipóteses: o quanto a oralidade e a memória constituem base para a construção de um acervo, e o quanto e como a oralidade pode ser base para uma referência patrimonial, para a pesquisa, e para a construção de processos museológicos. A partir dos dados e análises obtidos, um diagnóstico geral é apresentado.

\section{1 - Análise do Programa Coleta Regular de Testemunhos}

\section{ENQUADRAMENTO DO PROGRAMA}

O Programa Coleta Regular de Testemunhos originou-se em 2008 durante o projeto de implantação do Memorial da Resistência de São Paulo. A metodologia do projeto consistiu em reconstituir o espaço prisional com base nos relatos e memórias de ex-presos políticos. Um grupo de ex-presos, mais diretamente ligados ao Fórum de Ex-presos Políticos do Estado de São Paulo, foi convidado a participar. Esta participação contemplou a cessão de entrevistas, conversas com os diferentes profissionais das equipes técnicas, incluindo em especial as fases de elaboração da maquete que tenta reproduzir o espaço carcerário durante do funcionamento da prisão, a reconstituição da cela $3 \mathrm{com}$ a inserção de inscrições nas paredes, e os testemunhos que compõem a cela 4.

Em suas alíneas, defini-se por: 
“(...) Programa Coleta Regular de Testemunhos foi idealizado não só para dar continuidade aos trabalhos que serviram de base referencial para a concepção da exposição de longa duração. Mas também para ampliar os programas Centro de Referência e Lugares da Memória a partir da lógica que tem conduzido os trabalhos do Memorial, ou seja: assegurar o protagonismo às memórias daqueles que vivenciaram as experiências da resistência, em função dos exacerbados modelos de controle e repressão que atingiram diferentes contextos do país." (ARAUJO; BRUNO, 2009, p.60)

A coligação com os outros dois programas de pesquisa faz parte da intenção de criar um sistema de mapeamento e disponibilização de fontes, e vai além: as linhas de pesquisa foram criadas para embasar temas e argumentos que a instituição trabalha e trabalhará ao longo do tempo, transmitidas especialmente pelas ações educativas, na intenção proporcionar troca entre gerações: "Todas as linhas de ação do Programa Museológico do Memorial da Resistência de São Paulo foram concebidas para serem trabalhadas articuladamente, como forma de minimizar esforços, ao compartilhar informações e resultados." (ARAUJO; BRUNO, 2009, p.159). O MRSP filiou-se a Coalização Internacional de Sítios de Consciência, parte da estratégia de procurar instituições no mesmo âmbito para angariar parcerias. Como era o primeiro no Brasil, via a possibilidade de criar uma rede no Brasil e América Latina.

Internamente, como apresentado no capítulo 2, após o processo de implantação, o programa foi reativado em 2012, e desde então, vem seguindo ininterrupto. Para efeitos de análise caracterizaremos o programa por fases: Inicio em 2008 por entrevistas, sessões coletivas de conversa, interação com profissionais e técnicos do projeto, e participação nas reconstituições expográficas; Fase 1 (2012)retomada e reinício de coletas no formato de história oral em; Fase 2 (2013) sequência e primeira desenvolvimento do programa, e Fase 3 (2014) - a atual, continuidade e aprimoramento em $2014^{77}$.

O grande intuito do programa é ser uma atividade permanente de recepção de testemunhos ligados ao Deops/SP, para continuar coletando informações que reconstruam o cotidiano e o espaço, mas também "(...) permitam a compreensão do período em foco" (ARAUJO; BRUNO, 2009, p.161). Outra premissa é a localização de acervos, coleções e documentos junto aos entrevistados. Sua função é criar um acervo referencial, já que a instituição não abriga coleções materiais, alimentar suas

\footnotetext{
${ }^{77}$ As fases por um critério de caracterização, com base na metodologia, fluxo de trabalho e roteiro de entrevista utilizada em cada fase.
} 
exposições e ser incorporado e disponibilizado, futuramente, através do Centro de Referência.

\section{CRITÉRIOS}

No reinício do programa foi estabelecido o recorte para os participantes do programa, que deveria reunir em uma planilha um levantamento de pessoas que estiveram no Deops/SP (presos políticos, funcionários, familiares, etc.) para dar início as entrevistas. As categorias escolhidas pelo PCRT são:

1- Presos Políticos

2- Advogados e funcionários que estiveram no local

3- Familiares (pais, irmãos, filhos, cônjuge)

4- Amigos

5- Outros atores (pessoas que não tiveram qualquer participação ativa, tanto da repressão quanto da resistência, mas que de alguma forma tinham conhecimento daquilo que acontecia no prédio. Exemplo: moradores da região). ${ }^{78}$

O Programa também recebe e entrevista pessoas que não ficaram presas no Deops/SP, mas que por seu contexto de militância e outros fatores relevantes ligados a pessoas, fatos e lugares, são convidadas a registrar seu testemunho. O sistema de indicação entre ex-presos funciona muito bem para localização de colaboradores. Há também indicações de nomes feitas por pessoas que estão ligadas de outras formas ao tema. A facilidade no contato, idade e disponibilidade estão entre os principais pontos considerados para montar a agenda de entrevistas. Outro critério são idade e condições de saúde de possíveis colaboradores, os colocando em caráter de prioridade. Atualmente, busca-se cobrir organizações e temas não contemplados, como por exemplo, familiares, participações no pré-golpe, participação nos anos finais da ditadura ou fora do período de recrudescimento (1969-1975), pois a maioria dos entrevistados está concentrada nos períodos de maior repressão pós Al-5 e o desmantelamento das organizações de esquerda. Este espectro também tem ganhado ampliação pela inclusão de outros projetos no escopo do PCRT, como as exposições temporárias Advogados da Resistência e Política e Futebol, ambas geradoras de vídeo documentário a partir de testemunhos coletados para o tema da exposição. $\mathrm{E}$ ainda, as coletas ligadas ao aprofundamento e revisão dos textos do Programa

\footnotetext{
${ }^{78}$ Conforme atas de reunião desse período. Ata reunião. Memorial da resistência. PCRT. São Paulo, segundo semestre de 2012.
} 
Lugares da Memória, que busca pessoas ligadas a lugares específicos (exemplo: Quartel de Quitaúna, Sítio de Ibiúna, Casa da Lapa etc).

\section{QUADRO CONCEITUAL DE REFERÊNCIA}

No momento de sua retomada, o programa começou a procurar modelos e metodologias para construção do mesmo. O modelo escolhido é o trabalho realizado pelo Memoria Abierta (Ação coordenada de organizações argentinas de Direitos Humanos, 1999), que trabalha na formação de um archivo oral, fontes documentais, identificação e estudo de lugares de memória da história recente argentina ${ }^{79}$. O PCRT inspirou seus critérios com base nas categorias e metodologia utilizadas pelo Memoria Abierta.

A abordagem do arquivo oral do Memoria Abierta é bastante amplo e abarca a história recente da Argentina e seus contextos políticos e sociais de 1950 a 1983. Os objetivos se fundam em torno do conceito de terrorismo de Estado, para entendê-lo enquanto fenômeno histórico. Entre os objetivos estão os temas da resistência, repressão, e temas ligados ao período como golpe de estado, transição democrática, reabertura e questões de justiça como reconhecimento de corpos de mortos e desaparecidos políticos e sítios da ditadura. Mas sempre a partir das histórias individuais que se relacionam a estes temas.

Seguindo a metodologia do Memoria Abierta a primeira abordagem intencionada previa a realização de conversa preliminar com o entrevistado, no intuito de explicar os objetivos do programa, e sua ênfase na vivência que conheceu no Deops/SP. Isto resultaria no preenchimento de uma "ficha do primeiro encontro". O entrevistado receberia o roteiro de perguntas com possibilidade de supressão ou acréscimo de questões. Para a entrevista seria estipulado data e hora estipulando que não ultrapassasse 2 horas sempre que possível. Após a entrevista o entrevistado receberia a carta de cessão e a transcrição da entrevista por ele cedida. Mas ainda no início, esta ideia foi reformulada: o roteiro foi revisto e foi suprimida a "ficha do primeiro encontro", sendo substituída por um caderno de campo para registro dos primeiros

\footnotetext{
79 Segundo a apresentação no site da entidade: “Memoria Abierta reúne, preserva, organiza y difunde el acervo documental de organizaciones de Derechos Humanos y de otros archivos personales e institucionales vinculados al terrorismo de Estado. Produce testimonios sobre la vida social y política de los años 60 y 70 y trabaja sobre la memoria territorial y espacial del período de violencia política en Argentina." Suas entidades formadoras são: Asamblea Permanente por los Derechos Humanos - APDH, Centro de Estudios Legales y Sociales - CELS, Fundación Memoria Histórica y Social Argentina, Madres de Plaza de Mayo - Línea Fundadora, Servicio Paz y Justicia.
} 
contatos com os possíveis entrevistados, e 3 documentos comporiam a pasta de cada entrevistado (Carta de Cessão, Ficha técnica, caderno de campo). O caderno de campo efetivou-se em 2013 com caráter mais abrangente de registrar informações do contexto e momento da entrevista observadas pelos pesquisadores.

A busca por metodologias e programas de historia oral de mesma temática/problema, em instituições similares ou congêneres, prosseguiu em 2013 e 2014, na busca de melhor definição dos recortes, metodologias e políticas do PCRT. Uma diretriz principal dada ao PCRT é atentar para não repetir recortes já cobertos por outras instituições ou projetos.

No plano internacional as principais referências têm sido o trabalho do Memorial Abierta e do Archivo Oral de Vila Grimaldi. O Memorial da Resistência foi o primeiro espaço ligado a ditadura musealizado. No quesito testemunhos orais sobre o tema também são poucas as iniciativas no Brasil. As referências diretamente relacionadas a essa temática, por hora encontradas, são o projeto realizado pelo Diversitas/usp, em âmbito de projeto de pesquisa intitulado " Intolerância e resistência: Memórias da repressão política no Brasil"; e o projeto do IIEP ( Intercâmbio, Informações, Estudos e Pesquisas) chamado "Projeto Memória da OSM-SP (Oposição Sindical Metalúrgica de São Paulo)", desde 2007, sobre a repressão sofrida por trabalhadores metalúrgicos e militantes de São Paulo. Há também o projeto Memórias da Resistência, que realizou um grande número de entrevistas e um documentário, sobre os documentos do Dops de Santos encontrados por lavrador, e a resistência e repressão no interior paulista, mas não constitui ainda uma entidade, ou plano de formação de um arquivo oral. Além, claro, das bases de dados criadas pelos projetos e pesquisas das Comissões da Verdade, Comissão de Direitos Humanos,

Projetos similares e correlatos ao tema estão no CPDOC /FGV sobre memória política e memória de juristas brasileiros. Ainda na memória jurídica o Projeto Memória da Justiça Federal (Centro de Estudos Judiciários do Conselho da Justiça Federal) colhe depoimentos de juristas, familiares e funcionários do judiciário em todo Brasil ${ }^{80}$.

\footnotetext{
80 “(...) tem como objetivo a consolidação da memória institucional e o registro da contribuição da instituição à história social brasileira. (...) O Projeto Memória da Justiça Federal complementa o Programa de Gestão Documental da Justiça Federal, ao resgatar o acervo documental de valor histórico da Justiça Federal. Ambos integram os esforços da Secretaria de Pesquisa e Informação Jurídicas do Centro de Estudos Judiciários do Conselho da Justiça Federal na gestão dos conhecimentos institucionais." Manual de procedimentos do Programa de História Oral da Justiça Federal / Neide Alves Dias De Sordi; Gunter Axt; Paulo Rosemberg Prata da Fonseca. - Brasília : Conselho da Justiça Federal, 2007.
} 
Embora não exercendo a mesma destinação, o PCRT tem olhado para as Clínicas de Testemunho Sedes Sapientiae pela similitude da natureza dos relatos, em especial sobre os relatos de traumas e lembranças dolorosas, entendendo que a forma de captá-los pode ser muito melhorada com aportes da psicologia, psicanálise, e conhecimentos terapêuticos afins.

\section{ESTRUTURA DO PROGRAMA}

O PCRT abrange as atividades, ou o conjunto delas, próprias de um programa de História Oral. Engloba todas as tarefas das etapas anterior e posterior de gravação, além do momento de realização da entrevista. Entre elas estão a preparação da entrevista (levantamento de entrevistados potenciais, convite e agendamento, pesquisa e roteiro), gravação da entrevista, processamento técnico e tratamento dos arquivos gerados, até a geração de "fichas de saída" contendo as informações técnicas e as informações históricas inéditas colhidas.

O manual de procedimentos de 2013 prevê entre as etapas a seleção de entrevistados, convite + agendamentos (interno/externo), Pesquisa e Linha do Tempo Contextual, Roteiro de entrevista, Caderno de Campo, Organização dos documentos coletados (doação ou cessão), Transcrição das entrevistas, Revisão da transcrição, catalogação, arquivamento e uma etapa que foi vislumbrada, mas ainda não posta em prática, a transcriação ${ }^{81}$.

Foi também especificada neste manual de procedimentos formas e etapas da realização da entrevista propriamente dita. Nela, é especificado realizar, quando possível, dividir a entrevista em três momentos: registro de vídeo individual do entrevistado conduzido pelo roteiro, segunda parte onde o/a entrevistado/a fala sobre os documentos de seu arquivo pessoal (quando houver), e no terceiro momento uma conversa com o entrevistado mostrando fotos do edifício em diferentes momentos para estimular registro de informações sobre os documentos considerados inéditos e a

\footnotetext{
81 “Além da utilização de pontuação adequada, fala-se de um novo texto em que são suprimidas as perguntas e intervenções feitas pelo interlocutor, bem como as repetições, e busca-se uma organização das ideias de acordo com o que foi contado pelo colaborador. Temos, portanto, uma diferença substancial em comparação com o trabalho da transcrição literal, cujo objetivo central é a reprodução fiel do que está registrado. Estamos diante de dois tipos documentais textuais de naturezas diferentes e produzidos a partir de pressupostos específicos." Manual de procedimentos de pesquisa. Memorial da resistência. PCRT. 2013. p.23-24.
} 
sobre o edifício. E ainda a possibilidade de realizar uma visita filmada do entrevistado no espaço expositivo e salas do terceiro e quarto andar do prédio, sobretudo para aqueles que revisitavam o prédio pela primeira vez. Estas etapas, contudo, não chegaram a ser executadas. Prevalece o registro em vídeo no formato entrevistado e entrevistadores. Conversas anteriores sobre documentos e outros pontos da entrevista são registrados de modo informal pelo técnico de audiovisual que efetua as gravações. As entrevistas são realizadas em uma única sessão. Apenas alguns casos tiveram duas sessões de entrevistas, ou pessoas que participaram da chamada coleta regular e de entrevistas em outros projetos da casa, mais precisamente de exposições temporárias.

As fases início (2008) e primeira fase (2012) executaram a coleta das entrevistas, sem um tratamento técnico imediato e as mídias de armazenamento eram o CD e DVD. Este passou a ser realizado efetivamente a partir de 2013. Em 2012, foram implementadas uma planilha de compilação de informações principais, e o início de envio do material do Programa para transcrição do vídeo/áudio em texto. A partir de 2014, estão sendo efetuados uma nova identificação e backup de todos os arquivos gerados desde o início. Como também, a elaboração de uma base de dados (modo planilha) mais completa e sistematizada.

Em 2014, as diretrizes de gestão do programa definem como meta avançar na organização de dados e da metodologia do Programa, dois pontos cruciais para sua consolidação, e para que possa transmitir com eficiência as informações e conteúdos que salvaguarda. Outra demanda verificada é a urgência em realizar a sistematização de metadados, mesmo que de forma preliminar para sua utilização na reelaboração da exposição de longa duração prevista para ocorrer ao longo de 2015. Para esta feita, a opção estratégica é investir na formulação e preenchimento dos Resumos Analíticos, verificados como grande porta de entrada para as entrevistas, em biografias dos entrevistados, sinopses da entrevista de modo a extrair e sintetizar os conteúdos contidos nelas.

O objetivo é prever "(...) um resultado que possibilite o acesso facilitado ao acervo como um todo" 82 . Assim, entre os instrumentais selecionados para enfoque do trabalho em 2014 são:

- Padronizar e preencher planilhas (entrevistados, entrevistas);

\footnotetext{
82 Ata Reunião. Assunto: Cronograma de trabalho anual Coleta de Trabalho. Memorial da resistência. PCRT. 29/04/2014.
} 
- Sinopses/Minibiografias dos entrevistados até 2014;

- Edição de fotos $3 \times 4$ dos entrevistados;

- Resumo analítico começando das mais recentes para as mais antigas. Neste caso o volume de trabalho gerado é muito grande (mais de 180 horas de entrevista);

- Rever e finalizar o Manual do Programa e Metodologia (com auxílio de visitas técnicas e consultas especializadas);

- Formular uma proposta de política institucional do acervo de história oral (com auxílio de visitas técnicas e consultas especializadas).

1.

\section{Fluxo de processos - Coleta de Testemunhos}

- Levantamento Contatos

- Convite informal para participar

- Formalização do convite e agendamento da entrevista

- Pesquisa prévia fontes primárias, docs fornecidos pelo entrevistado, outros

- Pesquisa prévia (conversa por telefone com o entrevistado)

- Preparação do roteiro

- Registro dos contatos do entrevistado

\section{Coleta}

- Ficha técnica

- Termo de cessão

- Registros (vídeo, áudio, fotográfico)

- Indicações para o Coleta

- Indicações para o Lugares

\section{Pós-coleta}

- Caderno de campo

- Arquivar, identificar e realizar backup dos registros

- Editar fotografias $(3 \times 4)$ entrevistados

- Identificar e arquivar documentos doados/cedidos

- Preencher ficha técnica digital

- Levantamento coleta/ indicações

- Resumo analítico

- Planilhas - Base de Dados entrevistado

- Planilha entrevista - Base de dados entrevistado

- Criar Palavras-chave e Sinopse

- Arquivar carta cessão e docs pasta física

Figura-1 - Esquema representativo das etapas de processamento técnico de entrevistas produzidas pelo PCRT/MRSP. 
Um importante incremento tanto no número de entrevistas, quanto na sua diversidade, tem acontecido nas fases 2 e 3, sobretudo na última, em que entrevistas das exposições temporárias, de outros projetos e a realização de entrevistas conjuntas com o Programa Lugares da Memória, estão sendo incorporadas ao acervo gerido pelo PCRT. Assim, surgiu uma nova categorização das entrevistas em relação ao "Âmbito" ou projeto ou parceria pelo qual foi produzido. Nessas categorias temos: Coletas "Implantação", Coletas do Programa Regular (PCRT), Coletas de Mesas de Testemunho - Sábados Resistentes, Coletas Virada Cultural, Coletas "Exposição Advogados", Coletas "Exposição Política Futebol Clube", Coletas Lugares da Memória. Deverão ainda ser incluídas coletas realizadas dentro do projeto de exposição itinerante "Lugares da Memória", em cidades do interior e litoral de São Paulo.

As coletas ligadas a exposições e projetos têm recortes, roteiros e execuções geridos pelo escopo e encaminhamento de cada projeto, e chega ao PCRT propriamente dito, no momento de seu processamento técnico, e armazenado como uma realização do PCRT, com vinculação ao projeto de origem. Outro fator importante é o empenho na conexão entre o PCRT e o Programa Lugares da Memória. Neste caso, as pesquisadora dos dois programas trabalham em conjunto na pesquisa, levantamento de entrevistados e na elaboração do roteiro. Já as mesas de testemunhos correspondem ao projeto 2 de realização de coletas públicas e coletivas. Iniciaram em 2014 e estão em fase de experimentação. Não há um roteiro préestabelecido para essas coletas, apenas alguns acertos sobre os tópicos a serem tratados, e sua condução segue o esquema dos Sábados Resistentes. Prevalece o caráter livre na fala dos participantes, mediados por alguém ligado ao tema e/ou do Núcleo de Preservação da Memória Política, corealizador dos Sábados Resistentes.

O Programa é a porta de entrada das memórias do ex-presos políticos e outros relacionados. É, portanto, a porta de entrada de todo processo de identificação patrimonial, coleta/registro, processamento e, por conseguinte, do processo de musealização e preservação em potencial, e como decorrência a formação de um acervo dessas memórias. A partir do PCRT devem ser, portanto, geradas as etapas subsequentes da cadeia museológica.

Não há no momento um instrumento de avaliação institucional do Programa Coleta Regular de Testemunhos e de sua inter-relação com os demais programas. Percebe-se pelos documentos gerados no processo de trabalho que são realizados alguns balanços do Programa para planejamento, cronograma e gerenciamento. Ainda 
não há uma análise dos testemunhos, resultados e metodologias do Programa. Em fase de formatação estão o manual de procedimentos e a política institucional para o acervo de história oral em produção.

Como nosso intento é entender o PCRT, identificando seus conceitos, premissas, objetivos, seus modos de construção, meta, resultados; e os modos como desempenha metodologias, relações com os demais programas, com os entrevistados, como vêm sendo utilizado e vulgarizado, nos deteremos a seguir em duas etapas ou itens do fluxo de processos tem relação direta com estas questões, quais sejam os roteiros e os resumos analíticos.

\section{Roteiros}

Os roteiros são instrumentos base na realização da história oral. Por meio do roteiro se estabelece entre a individualidade da história do entrevistado e o foco do projeto em questão o conteúdo que comporá a entrevista e servirá como um provocador das memórias e da narrativa do entrevistado. O roteiro é um ponto crucial para o encaminhamento de objetivos e resultados traçados num programa ou projeto de história oral.

No MRSP o roteiro é estabelecido por meio de perguntas diretas, algumas mais objetivas sobre pontos específicos e outras abertas, que buscam captar a acepção do entrevistado a respeito do assunto levantado. Foram estipulados quatro tipos de roteiros, voltados para cada uma das categorias do Programa ( ex-presos, familiares, advogados, funcionários) em particular.

Desde a reimplantação do PCRT o roteiro vem sendo revisto constantemente conforme problemáticas e reflexões oriundas da prática e do cotidiano de trabalho. Como cita o documento "Atualização de roteiro de entrevista" (2013):

"Os encaminhamentos do Programa, à medida que foram acontecendo as coletas, apontaram para novas possibilidades com relação à condução das entrevistas. Desta forma, teve início a produção de roteiros personalizados, que tivessem como base a trajetória de cada um dos colaboradores."

Os motivos passam pela verificação do alcance das narrativas, a dificuldade da maioria dos entrevistados de rememorar com detalhes a descrição das instalações físicas e condições do cárcere, além do aumento do número de entrevistas, o que 
permite ter uma visão maior de conjunto, e da prática neste contexto e tema em particular.

Assim verificamos a existência de um roteiro padrão elaborado em 2012, cujo teor está centralizado e delimitado na descrição da prisão e passagem pelo Deops/SP em vários aspectos. Ele dá ênfase na descrição de situações vividas no cárcere (formas de tratamento e condições do cárcere, cotidiano, a edificação, com ênfase no espaço carcerário, carceragem, sala de delegados e locais onde ocorriam as torturas físicas), segundo a definição do Programa. A partir desse primeiro roteiro, novas considerações e ensaios têm sido feitos. A primeira tentativa foi a inclusão de novas questões no intuito de ampliar informações da militância política, razões para seu envolvimento, as implicações de passar pela prisão, sua visão sobre a condição de expreso político, e sobre esta experiência no contexto atual. $\mathrm{Na}$ fase dois do programa (2013) foi introduzida a realização de roteiros personalizados, juntamente com a pesquisa prévia sobre os entrevistados e uma linha do tempo para a formulação deste roteiro. O roteiro personalizado nesta fase trazia questões muito relacionadas a trajetória do entrevistado em paralelo ao contexto de prisão. Pouco depois, retornou-se ao roteiro padrão com inclusão de novas questões como já mencionado.

$\mathrm{Na}$ fase três do programa (2014), os roteiros também ganharam um aprimoramento. Sem deixar perder o foco principal do programa, a abordagem ganhou uma ampliação de modo a captar:

“1. Pequena apresentação da história de vida.

2. Os motivos/meios que o encaminhou para a militância política na época da ditadura, bem como suas participações em organizações, partidos, entidades, etc.

3. As circunstâncias de sua prisão política. Descrição da trajetória carcerária levando em consideração a resistência e a repressão dentro deste espaço/contexto. Nesta temática nos detemos mais tempo, pedindo detalhes do tratamento recebido, do espaço prisional e também da relação com os companheiros.

4. Os momentos posteriores a saída da prisão e o reestabelecimento da vida social.

5. Reflexão sobre trabalhar estas memórias nos dias atuais."

Resumo Roteiro Entrevista ex-presos políticos. PCRT.MRSP. 2014

$\mathrm{Na}$ fase atual continuam a realizar-se a pesquisa prévia e o roteiro personalizado, mas com um caráter diferente, que visa cobrir agora questões mais específicas de 
cada entrevistado captados durante a pesquisa prévia, complementar ao roteiro padrão, tornando-o mais preciso e objetivo, ou ainda atender ao roteiro de entrevistas realizadas em parceria com o Programa Lugares da Memória. Assim, informações pontuais como datas e locais de prisão, já são pontuadas anteriormente, dando mais mobilidade para a explicação do contexto e outros fatos que o entrevistado seleciona como importante. Já a pesquisa prévia tem sido intensificada no sentido de aprimorar ao mesmo tempo:

- roteiro e qualidade da entrevista

- captação de documentos primários e coleções pessoais ou outras

- preenchimento da ficha técnica e coleta de dados pessoais e da entrevista.

\section{Quadro 01- Roteiro de entrevista Padrão, categoria Presos Políticos. Ano 2012. Documentos de trabalho PRCT/MRSP.}

Presos Políticos

1. Localizar a entrevista (data, horário e local) e identificar o entrevistado (perguntar nome, data de nascimento e profissão).

2. Qual (is) organização (ões) militou?

3. Qual a data, e como se deu, sua prisão?

4. Quando preso veio direito para o DEOPS ou passou por outros órgãos antes de chegar aqui? Qual (is)?

5. Quanto tempo ficou preso no DEOPS?

6. Como foi a sua chegada neste prédio?

7. Quais as dependências pelas quais se lembra de ter passado neste prédio?

8. Quais suas recordações sobre este prédio?

9. Quais eram as condições do cárcere nesta prisão, e como era o cotidiano?

10. Como eram os interrogatórios?

11. Você se lembra com quem ficou preso neste?

12. Como era sua relação com os funcionários? Lembra-se do nome de algum?

13. Quando esteve preso no DEOPS conheceu algum indivíduo que havia sido preso por engano? Lembra o nome de alguém?

14. Recorda-se, ou teve conhecimento, de como era a relação de seus familiares com o DEOPS? Como se dava esta relação? Quais as dependências que os familiares podiam ter acesso?

15. Como se deu sua saída do DEOPS, e para onde foi transferido?

16. Como considera que foi esta experiência, e no que isto contribuiu para a sociedade atual?

17. Existe algo mais que se lembre, e que acredite ser importante relatar sobre sua passagem pelo DEOPS? 
Quadro 02 - Roteiro de entrevista Padrão, categoria Presos Políticos. Ano 2013. Modelo I. Documentos de trabalho PRCT/MRSP. Destacam-se as questões novas inseridas em relação ao roteiro inicial criado em 2012.

\section{Presos Políticos}

1. Localizar a entrevista (data, horário e local) e identificar o entrevistado (perguntar nome, data de nascimento e profissão).

2. Quando e como se envolveu com discussões sobre política ou com a militância pela primeira vez?

3. Qual (is) organização (ões) militou?

4. $\quad$ Fale de ações que desempenhou ou participou naquele contexto.

5. Qual a data, e como se deu, sua prisão?

6. Quando preso veio direito para o DEOPS ou passou por outros órgãos antes de chegar aqui? Qual (is)?

7. Quanto tempo ficou preso no DEOPS?

8. Como foi a sua chegada neste prédio?

9. Quais as dependências pelas quais se lembra de ter passado neste prédio?

10. Quais suas recordações sobre este prédio?

11. Quais eram as condições do cárcere nesta prisão, e como era o cotidiano?

12. Como eram os interrogatórios? E os lugares onde aconteciam?

13. Você se lembra com quem ficou preso neste?

14. Foi torturado enquanto esteve no Deops? Poderia descrever o local onde eram realizadas as sessões de tortura? (Caso não tenha sido, como os companheiros descreviam?)

15. Como era sua relação com os funcionários? Lembra-se do nome de algum?

16. Quando esteve preso no DEOPS conheceu algum indivíduo que havia sido preso por engano? Lembra o nome de alguém?

17. Recorda-se, ou teve conhecimento, de como era a relação de seus familiares com o DEOPS? Como se dava esta relação? Quais as dependências que os familiares podiam ter acesso?

18. Como se deu sua saída do DEOPS, e para onde foi transferido?

19. Esteve preso em outros locais?

20. Como foi depois que deixou a prisão? (Para conseguir trabalhar, na relação com os familiares, com os companheiros de militância).

21. Existe algo mais que se lembre, e que acredite ser importante relatar sobre sua passagem pelo DEOPS?

24. Como é ser um ex-preso político nos dias de hoje? É diferente dos momentos imediatamente posteriores à libertação, ainda durante a ditadura?

25. Como é vivenciar a experiência da prisão, da tortura, da clandestinidade e do exílio, seja de forma direta ou através das pessoas próximas?

26. Como é voltar neste lugar hoje? O que você sente?

27. Como você vê iniciativas como a realizada pelo Memorial da Resistência? Qual seu papel para as gerações atuais?

28. Como considera que foi esta experiência, e no que isto contribuiu para a sociedade atual?

29. Há alguma outra situação/acontecimento/experiência do período que considera importante relatar sobre sua história? 
Lugares da Memória

No período, que lugares se lembra que foram marcados por episódios importantes do contexto político e social? E locais diretamente ligados à repressão e resistência? (Lugares de reuniões, onde tenha ficado escondido, onde participou de alguma manifestação, onde possa ter sofrido tortura ou ter sido preso...)

Coleta de Testemunhos

Teria outras pessoas para indicar que tenham vivenciado o período e possam contribuir com esse projeto?

Quadro 03 - Roteiro de entrevista Padrão, categoria Presos Políticos. Ano 2013. Modelo II. Documentos de trabalho PRCT/MRSP. Destacam-se questões novas inseridas em relação ao roteiro de 2013 , modelo $I$.

Presos Políticos

1. Localizar a entrevista (data, horário e local) e identificar o entrevistado (perguntar nome, data de nascimento e profissão).

2. Quando e como se envolveu com discussões sobre política ou com a militância pela primeira vez?

3. Qual (is) organização (ões) militou?

4. $\quad$ Fale de ações que desempenhou ou participou naquele contexto.

5. Qual a data, e como se deu, sua prisão?

6. Quando preso veio direito para o DEOPS ou passou por outros órgãos antes de chegar aqui? Qual (is)?

7. Quanto tempo ficou preso no DEOPS?

8. Como foi a sua chegada neste prédio?

9. Quais as dependências pelas quais se lembra de ter passado?

10. Quais suas recordações sobre este prédio?

11. Quais eram as condições do cárcere e como era o cotidiano da prisão?

12. Como eram os interrogatórios? E os lugares onde aconteciam?

13. Você se lembra com quem ficou preso neste prédio?

14. Foi torturado enquanto esteve no Deops? Poderia descrever o local onde eram realizadas as sessões de tortura? (Caso não tenha sido, como os companheiros descreviam?)

15. Como era sua relação com os funcionários? Lembra-se do nome de algum?

16. Quando esteve preso no DEOPS conheceu algum indivíduo que havia sido preso por engano? Lembra o nome de alguém?

17. Recorda-se, ou teve conhecimento, de como era a relação de seus familiares com o DEOPS? Como se dava esta relação? Quais as dependências que os familiares podiam ter acesso?

18. Como era a atuação dos advogados naquele contexto?

19. Quem foi seu advogado? Que medidas ele conseguiu levar adiante para tentar resolver sua situação?

20. Como se deu sua saída do DEOPS, e para onde foi transferido?

21. Esteve preso em outros locais?

22. Como foi depois que deixou a prisão? (Para conseguir trabalhar, na relação com os familiares, com os companheiros de militância).

23. Existe algo mais que se lembre, e que acredite ser importante relatar sobre sua passagem pelo DEOPS? 
24. Como é ser um ex-preso político nos dias de hoje? É diferente dos momentos imediatamente posteriores à libertação, ainda durante a ditadura?

25. Como é vivenciar a experiência da prisão, da tortura, da clandestinidade e do exílio, seja de forma direta ou através das pessoas próximas?

26. Como é voltar neste lugar hoje? O que você sente?

27. Como você vê iniciativas como a realizada pelo Memorial da Resistência? Qual seu papel para as gerações atuais?

28. Como considera que foi esta experiência, e no que isto contribuiu para a sociedade atual?

29. Há alguma outra situação/acontecimento/experiência do período que considera importante relatar sobre sua história?

Lugares da Memória

No período, que lugares se lembra que foram marcados por episódios importantes do contexto político e social? E locais diretamente ligados à repressão e resistência? (Lugares de reuniões, onde tenha ficado escondido, onde participou de alguma manifestação, onde possa ter sofrido tortura ou ter sido preso...)

Coleta de Testemunhos

Teria outras pessoas para indicar que tenham vivenciado o período e possam contribuir com esse projeto?

Quadro 04 - Roteiro de entrevista Personalizado, categoria Presos Políticos. Ano 2014. Documentos de trabalho PRCT/MRSP.

Maria José Soares, Oposição Sindical Metalúrgica de São Paulo - OSM-SP

Percurso cárcere: Deops-SP

Entrada e saída cárcere: $\quad$ 1979, 1981

1. Localizar a entrevista (data, horário e local) e identificar o entrevistado (perguntar nome, data de nascimento e profissão).

2. Quando e como se envolveu com discussões sobre política ou com a militância pela primeira vez? Como se deu esse processo?

3. Qual (is) organização (ões) militou? (igrejas, movimento operário, associações de trabalhadores) Enfatizar Recife - DOM HELDER, Damião

4. $\quad$ Fale de ações políticas que desempenhou ou participou naquele contexto.

5. Como era o clima e cotidiano de repressão ao movimento operário e cristão e especialmente nas organizações de base?

6. Quais as maneiras que a repressão ditatorial se apresentava na vida dos trabalhadores e militantes sindicais? Conte situações que mostram o controle, a vigilância e o impedimento de organização sindical por parte dos patrões e da polícia militar e política.

7. Encontrou algum documento que comprove essa perseguição da polícia política? Algum lhe chamou atenção especial?

8. Como você avalia a participação feminina no movimento operário nesse período?

9. Qual a data, e como se deu, sua prisão? (DEOPS-SP, 1979 e 1981)

10. Como foi a sua chegada neste prédio? Quanto tempo ficou preso no DEOPS?

11. Quais as dependências pelas quais se lembra de ter passado?

12. Quais suas recordações sobre este prédio?

13. Quais eram as condições do cárcere e como era o cotidiano da prisão? 
14. Como eram os interrogatórios? E os lugares onde aconteciam?

15. Você se lembra com quem ficou preso neste prédio?

16. Como se deu sua saída do DEOPS? Sofreu algum tipo de repressão depois dela?

17. Quando e como foi depois que deixou a prisão? (Para conseguir trabalhar, na relação com os familiares, com os companheiros de militância).

18. Quais as consequências práticas para a sua vida? Houve processo, fichamento?

19. Você se considera uma ex-presa político? Por que?

20. Como é ser um ex-presa político nos dias de hoje? É diferente dos momentos imediatamente posteriores à libertação, ainda durante a ditadura?

21. Como é sua participação no Projeto Memória da Oposição Sindical Metalúrgica de São Paulo? Qual o significado desta atividade na sua vida e para o coletivo que participava do movimento sindical?

22. O que você acha sobre as indenizações e a atuação da Comissão da Anistia perante os ex-presos políticos?

23. Há alguma outra situação/acontecimento/experiência do período que considera importante relatar sobre sua história?

24. Lugares da Memória - você destacaria outros lugares que considera importante de serem reconhecidos como lugar de repressão e resistência durante a ditadura?

25. Coleta de Testemunhos - Você indicaria outras pessoas para prestarem testemunho nesse projeto?

26. Como é voltar neste lugar hoje? O que você sente?

ENCERRAMENTO - Como vc vê esta experiência de dar um testemunho? Agradecimentos

Em relação às questões, assuntos e conteúdos abordados pela entrevista, como dito anteriormente, um núcleo central versa sobre a prisão no Deops/SP. Nos roteiros personalizados da fase dois (2013) foram inclusas questões referentes a gênero e geração, Formação e atuação política, além de temas ligados a atividade exercida pelo colaborador(a), como no caso da atriz Dulce Muniz, em que foram feitas algumas questões relacionadas ao teatro e a produção cultural. Nesta fase 2, o roteiro padrão ganhou acréscimos importantes que além de um detalhamento da participação no processo de histórico e de militância, e a questões ligada a outros Programas (à exemplo da inclusão da questão dos advogados com vistas a preparação de exposição do tema "Advogados da Resistência"), incluiu a tentativa de conexão de redes entre pessoas e lugares ao pedir sempre aos entrevistados indicações para o próprio PCRT e para o Programa Lugares da Memória. Outro ganho significativo está na incorporação, ao final da entrevista, da reflexão: "Há alguma outra situação/acontecimento/experiência do período que considera importante relatar sobre sua história?":

"O objetivo desta questão a ser testada na próxima coleta de testemunhos é otimizar a oportunidade que se coloca no momento da entrevista de, além de obter informações e narrativas sobre a história do Deops, abrir espaço para que voluntariamente o colaborador 
fale sobre algo que considere relevante sobre sua experiência. Além do aspecto ético de respeito ao trabalho de memória exercido pelo entrevistado, esta pergunta, mais caracterizada como um estímulo pode sugerir elementos que tragam à tona aspectos relacionados com a memória coletiva do grupo". ("Atualização de roteiro de entrevista". MRSP. PCRT, 2013.)

Em relação ao presente, as questões "Como é ser um ex-preso político nos dias de hoje? É diferente dos momentos imediatamente posteriores à libertação, ainda durante a ditadura?" / "Como é vivenciar a experiência da prisão, da tortura, da clandestinidade e do exílio, seja de forma direta ou através das pessoas próximas?" / "Como é voltar neste lugar hoje? O que você sente?" / "Como você vê iniciativas como a realizada pelo Memorial da Resistência? Qual seu papel para as gerações atuais?", trazem a perspectiva do protagonista de sua participação na militância e no enfrentamento ao regime autoritário, permite que ele se coloque diante dos fatos e também no contexto atual, de como percebe essa experiência no hoje e como se relaciona com esse passado no agora. E ainda, o significado que o espaço agora Memorial da Resistência possui para ele/a.

$\mathrm{Na}$ fase 3 (2014) vemos um ganho ainda maior na incorporação das questões: "Como é voltar neste lugar hoje? O que você sente?" E no encerramento "Como você vê esta experiência de dar um testemunho?". Elas permitem apreender do entrevistado/a compreensão que faz de sua experiência e como ela pode servir a outras pessoas. E sem dúvida, sobre a posição de testemunho e de memória. Elas, ao mesmo tempo, levantam pontos de autorreflexão do entrevistado em como ele mesmo se enxerga nesse processo dialético entre presente e passado, e a importância de dar um testemunho em nosso contexto atual. Isto permitirá ao Programa e a pesquisadores futuros angariar dados preciosos para a reflexão sobre memória e sobre o papel das instituições ligadas a memória das ditaduras no Brasil, entre vários outros recortes.

A partir dos roteiros obtemos algumas considerações preliminares. A definição do roteiro é passo fundamental, pois "O roteiro fará a conexão, por meio de perguntas, entre a experiência pessoal do depoente com as questões teóricas que animam a pesquisa e a reflexão historiográfica sobre a instituição estudada." (De Sordi, 2007, p.12). A objetividade das questões como forma precisa de obter dados e informações históricas, e como praticado no PCRT, é o primeiro ponto a ser revisto e repensado, 
inclusive para atender adequadamente as expectativas dos dois lados, entrevistadores (MRSP) e entrevistados/as.

O programa precisa problematizar-se a partir de uma análise de sua definição geral, avaliando os resultados obtidos até aqui e as questões percebidas pelas equipes até aqui. Assim, poderá definir melhor seus objetivos gerais e específicos, o que trará, na sequência, melhores contornos para definir os procedimentos-padrão que serão utilizados em cada etapa de sua execução e sua metodologia. Isto tudo, sem perder de vista, que este acervo em construção, mais que uma fonte inédita, precisar ser pensada cuidadosamente, na medida em que, se torna uma fonte histórica e historiográfica:

" Um programa de história oral não deve ser um fim em si mesmo. Ele funciona melhor quando é um instrumento para possibilitar a construção do conhecimento histórico, e, portanto, instrumento para produzir reflexão historiográfica, tanto no que se refere aos fatos e aos eventos, como no que diz respeito à elaboração interpretativa. (...) O documento oral é o único documento que o historiador constrói. Ele, em geral, frequenta arquivos os mais diversos, que abrigam corpos documentais produzidos e reunidos por outras pessoas, em outros tempos. A história oral, pelo contrário, é uma intervenção direta do historiador na produção documental. Por isto, há uma série de cuidados que precisam ser tomados. Cuidados teóricos e metodológicos. Cuidados que garantirão a qualidade e a credibilidade do documento produzido. A história oral desenvolveu-se inicialmente como uma estratégia para dar voz àqueles personagens sociais que não tinham voz para a memória coletiva. Foi assim que, no pós-guerra, os historiadores começaram cada vez mais a entrevistar pessoas simples, pessoas do povo, pessoas que não eram lembradas pelos livros e pelos espaços públicos de memória, mas que tinham algo a dizer sobre sua visão de mundo, suas experiências de vida, sua percepção da realidade. Isto porque este algo a dizer falava-nos sobre usos e costumes, sobre experiências não registradas em páginas e documentos, sobre afetos e sentimentos que, de alguma forma, adquiriam universalidade e passavam a ter importância não mais apenas para aquele indivíduo isolado, mas para segmentos expressivos da sociedade. O documento produzido no âmbito da história oral obedece a uma série de critérios e prerrogativas técnicos, mas o conteúdo do depoimento oral jamais pode ser confundido como verdade definitiva. 0 que interessa num depoimento oral não é a precisão dos fatos ou a narrativa verídica dos eventos, mas a representação que 0 indivíduo fez desses eventos, a afetividade do indivíduo na sua relação com o entorno social, suas opiniões, suas 
impressões, suas vivências. Pois justamente entende-se que, ao contar sua história pessoal, o indivíduo pode estar contribuindo para contar a história de uma instituição, de uma comunidade, de uma época." (De Sordi, 2007, p. 8-9, grifo nosso)

\section{Resumos analíticos}

Um grande desafio em um arquivo oral é a recuperação das informações contidas nas entrevistas, ou de outro modo, a criação de um sistema de organização, compilação e recuperação de metadados.

O PCRT implementou a partir de 2014 o instrumento chamado "Resumos Analíticos" nos esforços de encontrar uma ferramenta que traga a fácil acesso os metadados da entrevista, de forma simples e organizada, mas também com um otimização do trabalho do profissional envolvido dado o volume de informações a serem captadas em cada entrevista, bem como do fluxo de trabalho como um todo. $O$ Resumo Analítico tenta consolidar várias ferramentas que, em separado, tornam seu preenchimento uma tarefa árdua e difícil a cumprir. O modelo principal e seus campos vêm do Memoria Abierta, com adição de alguns campos específicos e complementares. O Resumo analítico possibilita a compilação de informações importantes de diferentes instrumentais em um mesmo local, como informações de pesquisa e fontes levantadas, informações da ficha técnica, sinopse, informações de acesso/acessibilidade, e o conteúdo propriamente dito. O conteúdo dos registros mostra-se sempre como a principal questão a resolver sejam para as demandas internas de uso das entrevistas pelas demais ações e programas da instituição, quanto para o sua divulgação externa e o acesso à pesquisa. E que está contemplado no campo "resumo da entrevista".

\section{Quadro 05 - Campos do Resumo Analítico do Memorial da Resistência}

Resumo analítico - Um resumo de dados e análise da entrevista/entrevistado que servirá inicialmente a proporcionar o acesso público a entrevista e a futura descrição em base de dados.

Dados do entrevistado: nome, categorias, organização à época da prisão

Apresentação do entrevistado: biografia contendo local e data de nascimento, formação escolar e política, militância política, cárceres e datas das prisões, dados marcantes de repressão, exílio, atuação hoje.

Dados da entrevista: data, local, entrevistador, registro (câmera e fotografo), duração 
Resumo da entrevista: resumo contendo principais assuntos e analises e dados relatados pelo entrevistado. Utilizaremos alguns códigos que facilitarão o acesso ao vídeo: a marcação a de minutagem cada dez minutos, e para a catalogação posterior: < $>$ para indicar palavras chaves, " " para indicar expressões utilizadas pelo entrevistado. Os nomes de instituições devem ser indicados por extenso e com a sigla.

Os nomes de pessoas devem ser omitidas no resumo, a não ser no caso de pessoas que ocupam cargos públicos a época e pessoas desaparecidas ou assassinadas, porém as outras pessoas citadas, companheiros de militância, de cárcere, torturadores, devem alimentar a base de nomes (Estudar critérios para divulgação para o público amplo)

Fontes relacionadas: devem ser citados livros, artigos e outros testemunhos produzidos pelo entrevistado ou sobre sua atuação.

Como citar: Indicar como deve ser citada da entrevista

Restrições de uso: sim ou não

Referências:

Memoria Abierta. Testimonios y archivo : metodología de memoria aberta. 1a ed. Buenos Aires, 2011. Corporación Parque por la Paz Villa Grimaldi. Archivo y memoria. La experiência del archivo oral de villa Grimaldi. Chile, 2012.

ALBERTI, Verena. Tratamento das entrevistas de história oral no CPDOC. Rio de Janeiro: CPDOC, 2005.

\section{2 - Estratigrafia Social: a forma de ver e perceber dos agentes da memória patrimonializada, ou do patrimônio imaterial em questão.}

Desde que as micro-histórias foram consagradas pelos historiadores não se faz novidade ouvir a história pela visão e memória de seus protagonistas. Mais que uma alternativa ao trabalho ligado ao patrimônio, as memórias e histórias de vida tem se tornado quase uma prerrogativa dependendo da matéria e tema de interesse. As histórias locais e pessoais já nos são reconhecidas fontes de acesso e, em muitos casos, nossa única fonte de trabalho. Assim, passamos a coletar entrevistas, depoimentos, testemunhos também em trabalhos de preservação de patrimônio, incluindo-se os museus.

Significa dizer que passamos a incluir atores sociais no processo de musealização, diretamente ligados a um saber, a uma cultura ou a um fato histórico, para compreender um dado fato social ou cultural. 
É justamente o que ocorre com nosso caso de estudo: o acervo constituído é a base do museu, construída a partir de memórias de atores sociais envolvidos com o tema. E essas memórias se mostram como parte significativa do discurso expositivo apresentado. Assim, precisamos identificar onde e como essas memórias aparecem, seja na dinâmica do processo museal, mas também sobre como elas chegam à sociedade, aqui tomada pelo público, pois afinal preservamos para ela, como objetivo máximo. Neste raciocínio, duas das principais inquietações deste trabalho são examinar como esses atores sociais são envolvidos no processo, qual seu nível de participação, alcance; e como os resultados dessa interação são devolvidos a eles e apresentados ao restante da sociedade.

Pudemos apreender tais pontos nas falas dos chamados "protagonistas", nas entrevistas geradas no PCRT, e de outro lado, do público em geral por meio da avaliação de público realizada em maio de 2013, em suas questões qualitativas, e ainda, por dados gerados na aplicação de um questionário junto a alguns colaboradores do PCRT. Nestas fontes apuramos, por exemplo, porque os colaboradores aceitam participar do programa; qual função e importância atribuem ao PCRT; se encontram representação no programa e no Memorial da Resistência em geral; verificar o tipo de relação e percepção que estabelecem em relação ao Memorial da Resistência; aferir como se percebem neste processo, detectar expectativas, detectar seu entendimento sobre a patrimonialização de sua memória.

Estas fontes permitem responder dois níveis de questões pensando nos públicos atendidos por esse museu. O primeiro está em como este processo, ao mesmo tempo de reconhecimento e participação, é vivido por aqueles que concedem esses testemunhos, os "donos da memória". O segundo está em explorar como o imaterial musealizado está presente na exposição de longa duração.

Dentro das entrevistas do PCRT, além das questões relacionadas à militância política, a prisão e funcionamento do Deops/SP, encontramos outras questões que aludem aos reflexos dessa experiência na trajetória de cada pessoa. Dentre tais questões pudemos conhecer visões que os atores possuem à respeito de sua trajetória - sua importância para o presente e relação com iniciativas de justiça e memória, principalmente referente ao trabalho feito pelo Memorial da Resistência. Estes temas se alternam muito e não estão presentes em todas as entrevistas. Alguns são mais constantes como a questão "Como é ser um ex-preso político?", mas variam pelo encaminhamento da entrevista, e pela presença ou não no roteiro, que não faz obrigatória a colocação da questão ao entrevistado. 
Analisando as entrevistas do PCRT partimos de um levantamento da presença destes temas nas entrevistas para posterior análise de seu conteúdo. As análises ficaram circunscritas às questões:

- Como considera que foi esta experiência, e no que isto contribuiu para a sociedade atual?

- Existe algo mais que se lembre, e que acredite ser importante relatar sobre sua passagem pelo DEOPS?

- Como é ser um ex-preso político nos dias de hoje? É diferente dos momentos imediatamente posteriores à libertação, ainda durante a ditadura?

- Como é vivenciar a experiência da prisão, da tortura, da clandestinidade e do exílio, seja de forma direta ou através das pessoas próximas?

- Como é voltar neste lugar hoje? O que você sente?

- Como você vê iniciativas como a realizada pelo Memorial da Resistência? Qual seu papel para as gerações atuais?

- Como considera que foi esta experiência, e no que isto contribuiu para a sociedade atual?

- Há alguma outra situação/acontecimento/experiência do período que considera importante relatar sobre sua história?

- Como você vê esta experiência de dar um testemunho?

Iniciando pela auto reconhecimento de ser um ex-preso político, pudemos ver pelas entrevistas que esta denominação tem muito peso, e que apesar de estarmos em um momento de mais ampla divulgação do tema, conotações negativas associadas ao senso comum ainda persistem na sociedade. Ser preso é, em geral, associado à imagem pré-estabelecida do "bandido". Sobre a ditadura, a maioria desconhece a perseguição política, a repressão, justificada na ideia de "falsa ordem": “

É.... É ruim né? Nunca é bom uma coisa dessa porque a gente não interpreta a coisa como a massa. Quer dizer, você falar pra uma pessoa da massa, do povão, que você foi preso a primeira coisa é porque você fez alguma coisa, deve ser meio bandido e a gente não sabe, teve... Não é isso? (...) Então repercute essa coisa, quer dizer, de você ser interpretado dessa forma." (Adilio Roque, entrevista ao PCRT, MRSP, 17/04/13).

Para muitos, o isolamento foi uma opção, por motivos vários, mas que os trazem a falar somente agora, muitos e muitos anos depois. Mas o que prevalece, para todos, é a consciência de ter realizado algo bom, necessário, pois acima do fato de ter sido preso, está a motivação e razão da prisão resumida na luta por uma sociedade mais justa e igualitária: 
"Ah não, eu digo assim... Eu digo... Aí tem uma coisa: A nossa... A consciência de ter participado de um processo histórico e ser um dos protagonistas das mudanças que o país precisava passar, ele faz com que você seja político. Político atuante, se preso político ou não ser preso político é circunstância do momento, mas o problema é a consciência do seu papel de protagonista no processo político, isso tem que ser permanente, então eu não tenho arrependimento, não tenho magoas por ter sido preso, etc., felizmente não fiquei com essa sequela, fiquei com algumas físicas mas não com essa seqüela do ponto de vista assim psíquico, por que? Por que é uma consciência assim que eu adquiri e compete a cada cidadão ter consciência do seu papel na organização da sociedade e esse papel é político se ele faz, ele faz uma forma positiva, de transformadora, se ele não faz, ele faz uma política de legitimação do processo de exploração. Então a tomada de consciência disso leva obrigatoriamente você ou se acovardar ou ir pra frente, pra mim não alterou, honestamente não alterou, claro, criou receios e precauções, mas alterar a caminhada não." (Waldemar Rossi, entrevista ao PCRT, MRSP, 18/09/13).

"Tem. Lá você tá no fragor da luta né, então lá você está sendo testado né, e o que acontece é que você tem um grau de solidariedade que é em defesa da vida né. Hoje eu sou nós temos uma associação a "ANAP- Associação dos Anistiados e dos Aposentados Políticos" e a ideia é fazer a defesa da luta e fazer o ajuste com o estado democrático de direito, fazer o Estado reparar o que fez, tá certo, e você ter a continuidade da ideia de solidariedade. Porque a luta é tão extensa que tem muitos companheiros que ficaram na míngua e que ainda hoje, essa luta ainda continua, porque a anistia, na verdade quando veio a anistia, a anistia era só para os militares e para os sindicalistas, então essa luta que foi construída pela BASA, que as pessoas foram presas, essa luta não tinha eco, essa luta começou a ter eco assim, muitos anos depois, muitos anos depois. E ela ganhou consistência agora com a "Lei 10559" assinada aí em dois mil e dois, que envolveu todos os, caracterizou o que era ser um anistiado político, o que um perseguido, então criou uma base jurídica, é que antes tinham as chamadas medidas provisórias, não era nada consistente. Agora deu um grau de consistência, eu sou presidente dessa associação e nós trabalhamos a ideia da defesa dos anistianos e dos anistiados. Então a ideia de solidariedade continua até hoje." (Stanislaw Szermeta, entrevista ao PCRT, MRSP, 27/9/2013). 
"Olha, eu na verdade passado tudo isso, eu acho que é um grande privilégio, eu não me sinto uma vítima, claro, fui vítima de tudo, dessas absurdas violências, óbvio, não vou negar, mas o fato de a gente ter participado de uma maneira tão visceral de um momento da história, é uma coisa que eu acho que não... Colocando na balança o ganho é muito maior que a perda, porque quando eu vejo hoje, sento num vagão de metrô e vejo dez pessoas fazendo mensagem no celular, nenhuma lendo nada, eu penso, que rico que foi, a nossa juventude era muito rica, a gente não olhava um livro, a gente estava sempre buscando, buscando, buscando, conhecer, estudar, entender e batalhar para ter um mundo mais justo, mais humano, e hoje você vê as pessoas entregues a tecnologia, muitas vezes e completamente inconscientes ainda, muitas pessoas, mesmo com tudo que aconteceu agora que é fantástico, o MPL é meu herói atual, mas é uma coisa que a gente tá muito longe ainda de ter consciência do nosso grau de atraso cultural e educacional, que dizer, todo mundo precisa ter claro, um suporte governamental para que isso mude, obviamente, e não é com a burguesia do jeito que tá, com o bolso fechadinho a mil chaves que vai ter verba, não é a Dilma que vai fazer esse milagre para ter todo mundo acesso a educação e todo mundo gostar de conhecer, de estudar e entender, então o que você vê é uma coisa que te dá um alto contraste com a tua juventude, quer dizer, a gente viajava de uma cidade a outra para conseguir ter um lugar para eu conseguir escutar música do Geraldo Vandré com o disquinho no bolso e a vitrola na outra mão, de ônibus, um grupo de sete, oito pessoas, pô! Isso é riqueza! É garimpo, entendeu? Então eu acho que é um privilégio, é um privilégio você estar numa sociedade cheia de tanta violência e contraste, e ter força para batalhar, então nada a lamentar." (Leane Almeida, entrevista ao PCRT, MRSP, 23/07/2013).

Ou seja, a militância é um estado permanente, ininterrupto:

"Na realidade, a gente tem os olhos abertos e isso não fecha mais! Se não passa mais inocentemente e junta uma pessoa que esta deitada na rua porque não tem uma coisa, ou uma noticia de uma criança espancada ou uma coisa do gênero certo? E essa indignação se manifesta entende? Eu encontro sabe, a gente, já a própria Dilma que eu encontrei na Unicamp enfim, o Tarso Genro... você vai reencontrar, olha, dezenas e dezenas e dezenas dos companheiros daquele tempo, que continuam teimosos! Querem melhorar essa droga 
entende?" (Ladislaw Dawbor, entrevista ao PCRT, MRSP, 7/2/2014).

E quase todos manifestam que valeu a pena:

"As dificuldades econômicas, as dificuldades familiares, a incompreensão de parentes... "vale a pena tudo isso que vocês fizeram...? Agora tá aí desempregado..." Mas eu acho que valeu a pena sim. Que a história mostra tudo isso que a gente fez, valeu a pena sim. Acho que essa história, as pessoas tendo conhecimento assim, informando, participando, eles vão chegar a conclusão também, que valeu a pena por aquilo que a gente fez, né? (Djalma Bom, entrevista ao PCRT, MRSP, 13/2/2014)

A participação no PCRT, vista pelos próprios participantes, é sempre enxergada como uma oportunidade. Esta oportunidade, para parte dos ex presos políticos se refere também a participação em outras atividades, sobretudo dos Sábados Resistentes, e significa:

- Aprender algo novo e conhecer a experiência de outros militantes que também lutaram, sobreviveram e continuam a empreender lutas para melhorar o país, rememorar fatos dos quais participou, e tomar conhecimento de outros fatos políticos em que não teve participação.

- Resgatar: dignidade de cidadãos/cidadãs reprimidos/as durante os anos de chumbo; a memória e história do país, em especial a vigilância "intensa e opressiva" ocorrida em todo país sob o povo em toda história - não só nas ditaduras e Dops; vínculo com a história do país.

- Colaborar para que centenas de jovens conheçam "as arbitrariedades, barbaridades e assassinatos praticados naquele espaço de um departamento oficial do Estado de São Paulo"; a verdadeira história do Brasil seja escrita.

Para vida dos ex-presos políticos participantes, em como essa participação reflete em seu presente:

- Propicia a ampliação na participação de debates, palestras e entrevistas em escolas, comunidades, universidades, convites para outras entrevistas no próprio Memorial, contribuições em trabalhos acadêmicos 
etc. Isso Ihes permite falar aos jovens "ansiosos por conhecer um pouco da nossa história recente por outro ângulo que não os do "ensino" Oficial. Curioso que a narração dessa história por alguém que a viveu tem despertado o interesse de centenas de professores de História, que a veem agora sob outro ângulo" (resposta Waldemar Rossi).

- Trabalhar para consolidar nas pessoas a necessidade da preservação da memória.

- Auto-reflexão, auto-análise (e aprofundamento dela), autocrítica - sobre sua experiência de luta política e prisão, contra a ditadura, e também de pessoas que lutaram no passado, com objetivos similares, mas se envolveram com o poder e corrupção; por novos elementos que surgem e ajudam a analisar o atual momento histórico e sua vinculação no processo histórico como um todo, e o contexto político em nível mundial.

Participar, ou melhor, aceitar participar do PCRT significa:

- Um dever, uma obrigação de todos que sofreram perseguição, prisão e tortura, uma denúncia, para que não volte a se repetir, e para dar compreensão aos jovens de que eles são os responsáveis pela transformação, democracia e justiça social de que necessitam o país e a população marginalizada.

- Deixar registrada as suas impressões e convicções mostrando que as escolhas que realizaram foram fruto de "uma sintonia com a história mundial e a dominação de classe que está levando o planeta à autodestruição" (Leane).

- Colaboração (fraterna) para o avanço de nossa (gerações atuais), da consciência crítica sobre o Brasil no período ditatorial, suas violações, atos e resultados funestos.

Na relação com o museu e o edifício identificamos que voltar ao prédio onde tudo aconteceu varia entre estados mais ou menos confortáveis, sobretudo pelo fator tempo. Muitos demoraram a conseguir retornar ao prédio, mas hoje isso é atenuado e revisto. Alguns retornaram ao edifício apensa na ocasião e dia de ceder sua entrevista ao PCRT. As lembranças do sofrimento ali vivido são sempre fortes e inesquecíveis, mas a superação e a motivação de transformar as mazelas sociais, informar e 
denunciar tudo o que ocorreu, o que viram e viveram pelo terrorismo do Estado ditatorial, é sempre maior.

"É sempre meio ruim voltar ao lugar, você não fica muito a vontade, porque você vê aqui que [...] você vê os companheiros que sofreram torturas, os companheiros que foram mutilados, muitos saíram daqui pra morrer, foram tirados daqui, então é uma coisa, ninguém se sente bem, vem porque é importante a construção da memória, a construção de lutadores, construção, cada um fazia um pedaço, ninguém é líder porque é maioral, porque tem mais força, cada um foi um pedacinho, cada fazia um pedacinho, cada um faz esse processo de resistência e cada um faz, vamos dizer assim, no sentido de ser um exemplo. Todo mundo que abraça ideias libertárias, ideias que dão um espaço pras pessoas se desenvolverem, que a ideia libertária é essa né, a ideia de abrir espaço pra todo mundo trabalhar, pra todo mundo se desenvolver né. Então a volta aqui sempre é meio, é meio impactante e a gente quer até às vezes esquecer, às vezes quer fazer, - "Puxa vida, passou tanto tempo"! Mas o bom do tempo é que você nesse processo sempre de autocrítica, de crítica, de autocrítica você vai verificando se você construiu alguma coisa que desse fruto, esse é o lado importante da vida né e eu vejo que a maioria dos companheiros que optaram por esse tipo de resistência eles são companheiros que tem, assim, tem dignidade na vida né, trabalham e tem um senso crítico, tem um senso crítico do que acontece né." (Stanislaw Szermeta, entrevista ao PCRT, MRSP, 27/09/2013)

"É então. Eu comecei a falar que já foi mais complicado. Eu vim inicialmente aqui, em situações, em lugares como esse, mas já... Eu termino participando de tanta coisa aqui, que hoje em dia encaro com um pouco mais de naturalidade. É... (...) Agora, hoje em dia eu já entro aqui com muita facilidade, já vim aqui né, há muito tempo, já fui na OBAN, na Operação Bandeirantes tentando reconstitui coisa, tentando vê, enfim. $E$ muita palestra, muito papo, então, você vai... As coisas vão ficando mais distanciadas, a gente vai vendo com outros olhos né. Infelizmente a memória vai ficando mais seletiva né, você vai gravando, a memória você faz a sua memória, não é verdade?" (Manoel Cyrillo, entrevista ao PCRT, MRSP, 26/07/2013 e 16/08/2013. )

"Bom, agora eu já me acostumei um pouco. A primeira vez que eu vim foi meio chocante, foi." "(...) A primeira vez, é lógico, 
eu fui lá pra minha cela então vem tudo aquilo de volta, porque assim, a estrutura é a mesma, a mesma. Então um pouco mais bonitinho e tal, mas é a mesma. Aí... Mas depois você vai acostumando, agora mesmo eu fui lá... (risos) Mas sempre, é lógico, o teu inconsciente ele não esquece essas coisas. Então quando você entra ali você tem alguma lembrança." (Elias Stein, entrevista ao PCRT, MRSP, 06/09/2013).

“ (...) Eu, talvez esse impacto maior da volta ao, a construção, a coisa em si é, talvez ela até nem tenha tanto crédito, nunca indiferente vir aqui, isso cada vez que eu vier aqui, todas as vezes que eu vier aqui eu me lembro, cada vez que eu vim na Sala São Paulo e passo naquele pátio, eu me lembro da estrada de ferro, eu me lembro do solário lá em cima, eu me lembro de tudo o que aconteceu, cada vez que eu dou uma espiada lá assim no lugar de tomar sol, é uma história que tá presente, então, eu nunca será qualquer lugar né, é sempre um reencontro com seu passado aqui, mas assim o impacto talvez tenha tido por que eu já voltei, eu já fui visitar a cela [...] trouxe outras pessoas, talvez não tenha esse, mas por outro lado, eu acho o seguinte, é... Estes relatos aqui, não é, para mim tem todo esse... É a primeira vez, é tão impactante quanto por que, claro que vocês são as pessoas que nos coloca a vontade, são jovens, são gentes... Muito legal, acolhedoras, cordiais, inteligentes, sabem como conduzir as coisas, tudo isso né, mas é... O fato de estar aqui fazendo esse relato aqui, como até te disse no começo, para mim, particularmente, foi muito importante, foi muito diferenciado de outros depoimentos, talvez que eu já tenha até dado e etc., por que eu consegui ficar mais... Eu consegui olhar mais de frente né, até por trazer esses documentos, eu consegui ficar mais de frente com muitas coisas, inclusive com essas histórias daqui mesmo né, e... Então, é isso o que eu senti, foi... É diferente, foi importante, eu acho que foi... Alguma coisa que faz avançar mais, porque na vida você vai adquirindo as coisas que vão te avançando, eu acho que eu caminhei mais um pouco, caminhei legal dentro desse nosso passado, da minha própria história, não daquilo que eu penso né, e vocês ajudaram até a conduzir tudo isso e eles que estão quietinhos ali também... (Maria Aparecida Costa, entrevista ao PCRT, MRSP, 13/06/2014).

“ Ele não... Eu não tenho uma referência, porque ele modificou tanto que eu não consigo ter essa referência. Outro dia teve o ato lá na OBAN. Também, as modificações, a gente ficou tentando imaginar como era, onde foi, como foi que a 
gente atravessou aquele pátio. Às vezes ficava difícil. Inclusive porque a memória... é diferente, sabe. A memória da época não parece, quando você olha hoje, não tá se sobrepondo. É uma coisa um pouco descolada. Então... Agora, tem algumas coisas que, por mais que a gente trabalhe e já tenha trabalhado esse assunto, ainda mobiliza muito os sentimentos, né. Muitas emoções.(Guiomar Lopes, entrevista ao PCRT, MRSP, 08/04/2014).

E em relação a atual condição do edifício,

"E o quê você acha hoje do que se tornou esse espaço? Antônio: Esse espaço? Eu acho que foi uma das coisas boas, entende? Que se fez após a tal redemocratização, foi essa situação aqui. Tão boa e positiva quanto está sendo a do... Ainda que se acredite que não vai dar em nada, mas pelo menos se escracha, se tem liberdade de pessoas desabafarem, a Comissão da Verdade. Devendo (Não deixa) de ser altamente positiva. Pelo menos eles podem - As pessoas podem chegar lá e desabafarem, né? (Antonio Oliveira, entrevista ao PCRT, MRSP, 23/10/2013).

"E como você vê iniciativas assim como o Memorial da Resistência e tantas outras que agora estão surgindo em torno dessa verdade histórica que foi deixada esquecida, silenciada por tanto tempo? Elias: Ah, demorou demais, né? Demorou demais... Já faz - Vai fazer quanto? O fim da ditadura foi em 85. 95, 2005, vinte e poucos anos, agora que tá começando Não, começando não, já começou faz tempo. Tá começando a tomar vulto agora há pouco tempo, né? Que começa surgir comissão da verdade aqui e ali, centro de recuperação da memória, vários sindicatos estão recuperando histórias, depoimentos, é fundamental, mas é, essa história não pode ficar esquecida como ficou a de Getúlio. A do Estado Novo foi jogada pra baixo do tapete e Getúlio surgiu como um herói nacional... $E$ todos os torturadores foram anistiados, na época... Agora, essa história aqui, essa recuperação da memória, depoimento, só vai ter sentido se houver punição, houver denuncia, por exemplo: Não é só torturadores, empresas que financiaram a repressão; órgãos de comunicação, enfim, a sociedade tem que saber quem que participou dessa monstruosidade, né? Que foi a ditadura, que atrasou - Fez perder uma geração, atrasou o país assim, nós estamos pagando até hoje esse... Os males que a ditadura fez, até hoje. (...) Conseguiram deixar na cabeça de muita gente 
que na época da ditadura não tinha bagunça, não tinha violência, não tinha bandido, não tinha corrupção... (risos) Barbaridade... Mas essa ideia tem na cabeça de bastante gente. Então a verdade precisa aparecer para eles verem que: “Ó, não foi bem assim não!" Corrupção, tinha, mas era proibido de denunciar. Violência existia, mas era muito pior que agora, porque era uma violência do estado contra você, não era de um individuo contra outro". (Elias Stein, entrevista ao PCRT, MRSP, 06/09/2013).

E sobre o papel dos Memoriais ou Centros de Memória sobre a ditadura, e ainda se eles proporcionam alguma forma de reparação, eles apontam que tais espaços tem um papel fundamental para:

- Lembrar nossa história; dar valor as lutas de seu povo, informar sobre lutas contra opressões e limitações da liberdade humana, e promover estudos de história contemporânea do país.

- Disponibilizar o material de forma didática, considerado "como instrumento fundamental da revelação da verdade histórica contada por quem a viveu e não mais pelos dominantes, responsáveis diretos pelas misérias materiais e humanas que afetam a vida de milhões de brasileiros/as" (Waldemar Rossi).

- Honrar e homenagear toda uma parcela de militantes que dedicou sua vida à resistência, e teve a vida ceifada nas torturas.

- Fornecer suporte aos movimentos de vanguarda política e "manter viva a chama das lutas libertária", para que autoritarismos não voltem a se repetir.

- Reparar as injustiças cometidas com a divulgação dos atos e violações cometidos, dando estímulo e clareza às lutas atuais, pois "Resgatar a memória e a verdade é uma forma de reparação e aprendizado." (Albertina Bernacchio).

Os ex-presos políticos consideram que sua trajetória e história estão contempladas na instituição, pois "Sim, não só porque lá está a cela em que fiquei preso, mas também porque o Memorial consegue transmitir aos visitantes uma visão bastante real do que foi a repressão na ditadura. Acredito que as fotos, os filmes e os áudios deixam uma forte impressão nas pessoas que vão lá." (Elias Stein, 2014). E 
também, pois sua história é vista no conjunto da história coletiva, ou da ditadura: "Creio que minha história/trajetória está amplamente registrada pelo Memorial da Resistência por tudo que aqui tem sido dito, repetido e gravado. Mas, o fundamental é que o Memorial realiza o registro histórico de centenas de casos da podridão que envergonha e conspurca a história do Estado de São Paulo e do Brasil."(Waldemar Rossi, 2014). Há ainda o caráter imaterial presente nas instalações como revela Maria Aparecida Santos no seu comentário:

"Penso que todos os que passaram por lá, por motivações políticas, ideológicas, libertárias, deixaram lá as suas presenças, os seus sonhos, as suas utopias, as saudades dos sonhos não realizados. Apesar da opressão 24 horas diárias, as crueldades, as fraquezas, o otimismo, a solidariedade entre nós, era o único alento, ainda se sonhava. Se sentir minha história/trajetória contemplada no Memorial for ver meu nome gravado na parede de uma das celas e participar de relatos, posso dizer que fui contemplada. Mas será que nossa passagem por lá é só isso? Não sei se entendi bem a pergunta." (Maria Aparecida Santos, 2014).

Há ainda o registro da história/testemunho individual, que de acordo com os objetivos do PCRT apresentados aos colaboradores, também contempla sua intenção de registrar e divulgar esse passado. A maioria não acredita ou gosta de personalismos, mas consideram que os relatos prestados no Memorial da Resistência foram "um fiel testemunho". Associando estas experiências ao espaço físico, temos um relato que aproxima bem a ideia e significados que estão sendo construídos em torno do espaço, dos testemunhos. Isto entra em sintonia com o discurso expositivo e o que é apreendido pelo público:

"Tem uma coisa que eu gostaria de falar, assim, com relação a esse local. Esse local hoje pra mim não é um local de tensão. Aliás desde o início quando foram inauguradas as celas, quando eu entrei lá, tem alguns amigos que não conseguem vir aqui, acham que isso aqui tinha que ser destruído, né? Mas ele não é pra mim isso. Eu não me sinto... Eu me sinto comovida ao lembrar algumas coisas, mas eu não me sinto mal, entendeu? É como se... E isso aí eu nem sei se... Não é uma coisa racional, é uma coisa mais do sentimento mesmo. $\mathrm{O}$ fato de... Eu acho que é uma conquista ele existir hoje como ele é. Entendeu? Mais ou menos as mesmas coisas guardadas, os desenhos, os rabiscos dos meninos, querendo, começando a escrever, a letra, o "t" virado (risos) é um pouco aquilo, e isso aqui permaneceu. E permaneceu com outra... Com outra finalidade, permaneceu de um jeito que há 
encontros aqui né? Lá em baixo os jovens tomam conhecimento do que aconteceu aqui nesse momento, pra que ele nunca mais aconteça, não se repita, como a gente fala toda a hora, então isso é uma coisa... Boa. Eu não venho aqui, eu nunca estive constrangida aqui, eu nunca estive amargurada aqui. Eu posso me emocionar com as histórias, com o que acontece, né? Mas eu não venho aqui - É como outro dia, a mãe do Darci, do rapaz que se matou lá na... (...) Ela foi chamada numa homenagem ás mulheres, agora, pela Comissão de Anistia (...) O fato de falar, o fato de não só ela poder falar, mas outros falarem também, tem um significado muito grande pra gente, porque tudo que aconteceu, a tortura, os maus tratos, a violência, né? Você já não... Você já não carrega aquilo porque você consegue expressar aquilo. Aquilo passou a ser de domínio que não só seu, portanto a pessoa que fez aquilo, ela no te sequestrou, você não é mais sequestrada dela. E quando a Darci falou, ela vivia tão intensamente a morte do filho, ás vezes sei lá, toda a tragédia, que ao falar, ela terminou a fala assim: "Eu cheguei aqui com a morte. E eu saio daqui renascida." (...) Né? Então eu acho que esse processo nosso, que foi de vocês, fundamentalmente, de transformar esse espaço numa outra coisa, deu vida, o que era morte ficou pra trás. Passou a ser um espaço de vida." (Entrevista de Rita Sipahy ao PCRT, MRSP, em 19/03/2013.)

Quanto aos demais públicos beneficiários do museu, tomados aqui pelos visitantes em geral, sua forma principal de contato com o que o museu oferece é a visita à exposição de longa duração. Nela, os dados de experiência de visita foram observados nas respostas às questões abertas, coletadas em pesquisa de Avaliação de Público, realizada pela equipe do Memorial da Resistência em maio de 2013. Foram sete questões abertas, analisadas em conjunto ${ }^{83}$.

Iniciando pelas questões "O que você considera que foi mais interessante na visita de hoje?", e "Entre tudo o que você viu e conheceu nas exposições hoje (vídeos, maquete, tela interativa, celas, corredor para banho de sol, testemunhos/cela do cravo, centro de referência etc.), você poderia destacar o que foi mais marcante? Por quê?", o maior percentual de respostas faz referência direta às celas, fazendo menção a reconstituição do espaço prisional como um todo, e/ou a algum elemento constitutivo

\footnotetext{
83 As questões são: Qual a principal mensagem transmitida pelo Memorial da Resistência, O que consideram mais interessante em uma visita ao Memorial da Resistência, $\mathrm{O}$ que mais marcou na exposição visitada, Descobriu algo novo no Memorial da Resistência, Quais contribuições o Memorial proporciona, Outros temas que gostaria de ver expostos no Memorial da Resistência, Espaço para sugestões.
} 
das celas 3 e 4 (Módulo C, Exposição de Longa Duração), onde se destacam as palavras: celas, inscrições, depoimentos, (reconstrução do) espaço. As celas 3 e 4 foram as mais citadas para o que acham mais interessante na exposição, perdendo apenas para as respostas que utilizam o termo <celas> no geral e depoimentos dos ex-presos. Em todo questionário (questões abertas), o espaço prisional foi apontado em $73.9 \%$ (80 vezes), onde 50,45 \% ( 55 vezes) mencionam as celas, completados por menções a detalhes específicos como os depoimentos e inscrições nas paredes, elementos das celas 4 e 3 respectivamente ${ }^{84}$.

A questão sobre o que achou mais marcante apresenta o seguinte resultado nos comentários do público participante de pesquisa:

\section{Celas no geral}

espaço restaurado - é um resquício histórico para não esquecermos, muito triste, deprimente, é uma parte que emerge as pessoas naquela época e naquele contexto, espaço pequeno, super lotação das celas, você sente o que eles sentiram enquanto estavam presos, porque aquilo que aconteceu de fato não é só foto ou escultura, te faz pensar na liberdade, reconstituição com siglas das organizações e lista com "heróis do povo", porque dá a sensação de prisão e como eles contam, a parte mais aterrorizante era o barulho das trincas das portas, ver as portas da a sensação impactante, sensação muito forte, não deixa de imaginar $15 / 20$ pessoas presas ali, cela, convívio dos presos o que eles passaram, parece estar dentro do lugar onde ficaram, celas por conta do sofrimento imposto aos presos.

Cela 3 /

inscrições nas paredes
Clima pesado fez ficar pensativo, "a voz das pessoas é muito forte, marcante", porque parece que dá pra sentir lá dentro uma energia diferente, porque saber que tanta gente importante no país ficou presa sensibiliza e deixa feliz, porque eles conseguiram dar a volta por cima, porque é muito forte (...), "Parece que tá todo mundo lá ainda", m o período), pois é muito real, a superlotação, as condições do banheiro, autenticidade, muita originalidade porque faz os visitantes se emocionarem por estarem no mesmo local que os presos estiveram, remete ao que eles passaram transmite a sensação de estar no lugar deles e o sentimento deles, oportunidade para ver como era realmente e como as pessoas convivem lá dentro, pequena, muita gente num lugar só - porque foi desconfortável pensar nisso

Inscrições - escritos nas paredes eram uma forma de expressão, o registro é forte e impressiona - peso histórico, as inscrições na

\footnotetext{
${ }^{84}$ Os números tem como base o total de 109 questionários aplicados. Uma pessoa não respondeu a questão "31. O que você considera que foi mais interessante na visita de hoje?". Dados do relatório final da Avaliação de Público, MRSP, junho de 2013.p. 32.
} 
parede porque foram as pessoas que estiveram aqui que escreveram aquilo (aproximação com a história), "São pessoas que eu conheci através da leitura, estando no mesmo local que elas estiveram", os escritos na parede, houve pessoas presas aqui, é real, mais presente; analisar a pessoa que ficou presa, o que ela pensava, o que sentiu e sofreu para deixar seu nome ali; Gostou. $O$ registro das pessoas, seus nomes, saber quem foram; porque foi uma forma de exteriorizar o que estavam passando, "Eles não sabiam se iriam sair daqui e se alguém veria as inscrições - como de fato não foram vistas", "não é presídio em que você sabe que será solto algum dia."

\section{Cela 4 / áudio / depoimento / testemunho}

Sábado e domingo, não tinha tortura, laços de amizade fortalecidos, - lado bom que eles conseguiam tirar da prisão; Depoimento e inscrições porque eles conseguem voltar aqui depois de tudo o que aconteceu pra deixar suas impressões de novo; gente que viveu isso contando a história deles; porque emociona as pessoas ouvir as palavras do próprio sujeito e também a forma que foi montado o áudio; por possibilitar o acesso às próprias pessoas que ficaram presas; interessantes, tristes, a forma como trataram as pessoas; "a

\section{Depoimentos}

\section{Cravos} história está viva ainda, mas a gente sabe que teve muito mais do que isso que está sendo"; foi algo que aconteceu de verdade; porque podemos sentir o que passaram as pessoas que estiveram aqui; relato de uma vida, experiência vivida; porque mostrou o que aconteceu, as pessoas que estiveram aqui falando o que acontecia com elas; "Porque sabemos passaram, mas escutar deles mesmos é muito tocante."; contavam a realidade, é chocante a foram como foram tratados os ativistas aqui (no DOPS); porque foi um momento que o BR mudou muito e o povo sofreu muito com isso; "Pela ausência de realidade do resto da exposição, o áudio foi tocante por mostrar algo visceral; "Dá mais "carne" ao sentimento dos presos que estiveram aqui e que lutaram pela democracia".

Áudio e cela 3 - porque transporta para aquela realidade, pelo menos pra uma parte de tudo o que foi vivido, ficou chocada com o que eles passaram,

Cela 4 (depoimentos) e cela 3 - sentir como era o espaço em que eles viviam

"a história dos cravos vermelhos e o reencontro com a militante Vera porque ela cuidou da outra mulher e a reencontrou, isso foi emocionante"; "o cravo no meio da cela 4. Sensação de paradoxo, ver uma flor viva, iluminada na cela escura, foi um choque por uns segundos"; "a história dos cravos vermelhos e o reencontro com a militante Vera porque ela cuidou da outra mulher e a reencontrou, isso foi emocionante"; "a história do cravo vermelho, porque teve solidariedade compartilhamento, dividiram bolo, ressaltou a humanidade. 


\section{Outros elementos do} espaço carcerário iluminação das celas, ver o jeito que eram tratados os presos (perguntou se a iluminação era desse jeito no período)

fiel ao original. Reestruturação do predio porque tem oportunidade de ver o que foi o Dops e do que aconteceu aqui.

andar no espaço prisional - ter uma ideia de como era-história em seu lugar

banho de sol e celas - por causa da falta de humanidade

banho de sol - bem montado o espaço, bastante realista, se realista sentiu no lugar dos presos; por poder se colocar no lugar dos presos ao se enxergar no espelho; frase do banho de sol - porque se imaginou enjaulado, naquela situação descrita, com os guardas olhando; a frase a fez pensar no cotidiano dos presos, estar no mesmo espaço dos ex-presos (citou o corredor de sol). / Sensação ruim e compreensão dos ideais dos militantes

cela 1- detalhado o cotidiano dos presos, quantidade de pessoas na cela mexeu porque é forte

o barulho da porta indicava o tipo de atividade que se seguiria, isso foi tocante pela consciência do cotidiano que era levado.

"o barulho da fechadura" - sensação de perder liberdade, não poder se expressar. Som simbólico de liberdade (ou no caso a falta dela)

Outros

Elementos da exposição temporária Insurreições

Elementos da exposição longa duração (linha do tempo, informações históricas, telas interativas etc)

Comentários diversos

Quadro 6 a 10 - Síntese de respostas apresentadas pelo público em suas impressões sobre a exposição de longa duração. Avaliação de Público, MRSP, maio-junho2013.

Vimos pelas menções do público que os testemunhos perfazem o principal elemento da exposição e do museu, completado pelos elementos da materialidade do local, cujo destaque é a cela 3 que reconstitui o ambiente da cela original. Juntos, compõe aos olhos do público um dueto material e imaterial, por onde a história lhes é contada e registrada. De acordo com o relatório final da avaliação de público em análise:

"Os Depoimentos na Cela 4 do Módulo C da Exposição de Longa Duração foram o segundo ponto mais marcante entre os 
visitantes, citado de diversas formas diferentes e por motivos vários. Ao mencionar os depoimentos dos ex-presos políticos, as respostas eram complementadas por: "muito tristes"; depoimentos realistas; vivência dos presos; "adoro escutá-los". A Cela 4 é comumente identificada como "a cela da rosa". Diorama, vídeos e telas interativas também foram lembrados pelos visitantes. Cinco respostas mencionaram a monitoria ou explicações dos educadores do Memorial da Resistência.

A exposição de longa duração, como um todo, foi citada diretamente uma vez. Entretanto, várias apreciações fazem referência ao conjunto da exposição, dando como resposta "tudo" ou "não tem nada faltando", ou como se observa nas afirmações abaixo, que versam também sobre tema e conteúdos da exposição:
"saber o nome das pessoas mortas na ditadura"
"falar sobre o regime militar com os alunos muito importante para a memória do país" "diversidade das exposições- maneiras diferentes de entretenimento para o público"
"descobrir como as pessoas foram tratadas"
"a história que foi vivenciada pelas pessoas aqui nesse prédio"
"bastantes documentos, mostra todas as partes da repressão, resistência, etc"
"Testemunhos sobre torturas"
"Testemunhos e a experiência de estar dentro das celas" ${ }^{85}$.

Como síntese, encontramos entre as respostas da questão "Qual é a principal mensagem que o Memorial da Resistência Ihe traz?", o seguinte: "Conseguem, através do áudio e recriação do espaço, passar a mensagem de importância da história e de não deixar que aconteça de novo."

As apreensões do bem imaterial (testemunhos) no Memorial da Resistência são percebidas de duas formas, conforme a posição do público receptor, a saber, os atores sociais ou público em geral. Não há uma referência direta ao termo patrimônio ou imaterial por nenhum deles. O elemento comum, identificado por todos, é a narrativa das experiências vividas por pessoas que sofreram perseguições políticas e violações de direitos naquele lugar, que se outrora chamava Deops/SP. Estas narrativas estão reconstruídas e são identificadas na reconstituição do espaço carcerário, apresentado na exposição de longa duração - e que é o único espaço remanescente do período de funcionamento da instituição Deops, mesmo com todas as alterações sofridas. Às narrativas soma-se - na forma e conteúdo - o registro do

\footnotetext{
${ }^{85}$ Memorial da Resistência de São Paulo. Avaliação de Público. Segundo Trimestre de 2013. Relatório Final. Equipe Memorial da Resistência de São Paulo, Junho de 2013. p. 33.
} 
que ocorreu, contado por pessoas que viveram tais fatos. Unidos à força da materialidade da construção carcerária, de um lado ex presos revivem e acionam canais de memória ao visitar o lugar. De outro, visitantes tem a sensação de proximidade e realidade: proximidade por compartilhar nas vozes dos ex presos e suas histórias, o que significou estar preso ali, e realidade por estar no espaço físico onde tudo aconteceu, reforçado pelo fato deste lugar ser uma prisão. Em todos, o fator emoção é forte e constante componente. Para os ex-presos isso significa reviver o passado, as memórias boas e ruins, as memórias de dor e traumas, e as de solidariedade e conquistas. Para os visitantes a emoção comove e traz sensações de estar no lugar daqueles que passaram pela prisão e torturas. O espaço expositivo é, portanto, o principal lócus de ir e vir da informação e do patrimônio musealizado. É o lugar máximo onde ele é comunicado. Vimos que outros canais possíveis de contato com esses testemunhos ou não estão ativos no momento, e os que estão presentes, como as "Rodas de Conversa" realizadas pela ação educativa, alcançam outra intensidade já que esta oferta é circunscrita a grupos. Vale destacar aqui que estes outros meios são as exposições temporárias, as ações educativas, Sábados Resistentes, site e facebook do museu. Os relatos ou testemunhos coletados ainda não estão à disposição do público, pois passam por processamento técnico e definição de como serão as formas e políticas de acesso do material.

"A família toda, a gente tem orgulho dessa postura que os meus irmãos tomaram, que eu tomei, tivemos apoio da família, durante todo o tempo, tivemos apoio das companheiras durante todo o tempo da nossa militância, e eu não digo que isso é um orgulho ou não, mas eu dizia o seguinte é o maior prazer da minha vida de estar hoje aqui conversando com vocês dentro desse prédio aonde foi o maior símbolo, um dos maiores símbolos das torturas, da repressão, na ditadura Vargas, na década de 30 e 40, e na ditadura civil militar de 1964. E de eu estar aqui hoje, né? Provou que nós tínhamos razão. Provou que meus irmãos tinham razão. $E$ isso valeu a pena porque hoje a gente está aqui, né? (...) Então isso pra mim é uma realização, eu me sinto realizado. (...) $E$ to convencido de hoje, de que a minha tarefa, de transferir pras novas gerações, aquilo que os companheiros que foram reprimidos na ditadura Vargas não puderam fazer, é uma missão, uma responsabilidade minha de transmitir pras novas gerações toda a experiência que nós tivemos dentro desse prédio e todas as experiências políticas que nós tivemos no período da ditadura. Isso foi a razão de eu aceitar o convite que vocês fizeram pra fazer essa pequena conversa aqui. $E$ to aí a disposição quando vocês precisarem, tá! (...) Espero que essa 
atitude nossa aí de vocês evite que se repita de novo no Brasil, experiência, pode repetir até pior do que essa, porque tem aquela história, tem aquele ditado que raio não cai no mesmo lugar, não é bem verdade. Pode cair de novo no mesmo lugar! (risos)"

(Derly Carvalho, entrevista ao PCRT, MRSP, em

18/10/2013.)

\section{3 - Estratigrafia institucional: diagnóstico da ação preservacionista}

Considerando o diagnóstico uma importante ferramenta para a análise situacional, uma leitura de cenário, ou o conjunto de procedimentos que levam à identificação de uma questão-problema, de modo a oferecer subsídios para uma estratégia de ação, vimos que seu emprego caberia muito bem no auxílio das análises e dados colhidos no MRSP, frente a problemática do presente estudo.

Desse modo, o modelo ou metodologia de diagnóstico servirá aqui como estratégia, para unir o arcabouço de dados, com as questões alvitadas, e assim estabelecer uma análise mais geral e completa. Além dos documentos, dados e análises discorridos, nos capítulos e tópicos anteriores, acrescentam-se dados das avaliações museológicas realizadas na instituição de 2009 a $2013^{86}$.

\section{1) Breve histórico da Instituição \\ - criação, processos de gestão e constituição como personalidade jurídica; \\ - construção de sua relação com a sociedade.}

Surge de duas reivindicações do Fórum de Ex Presos e Perseguidos Políticos do Estado de São Paulo. Em 2002, o edifício é reaberto a visitação pública, após passar por obras de restauro. È gerido pelo Arquivo Público do Estado de São, delegando ao espaço carcerário as celas totalmente descaracterizadas com o nome Memorial da Liberdade. Em 2004, o edifício passa para a gestão da Pinacoteca do Estado, onde passa a funcionar como Estação Pinacoteca, e após nova reforma, que demoli as celas do fundo do complexo, duas celas internas, e fecha o elevador de acesso aos andares superiores, próximo a antiga carceragem. Entre 2006 e 2007, entram em voga discussões da Justiça de Transição. Ao mesmo tempo, em São Paulo, o Fórum de ExPresos e Perseguidos Políticos apresenta petição ao Governo do Estado, para que o

\footnotetext{
${ }^{86}$ Nos anexos encontra-se um documento que apresenta as avaliações realizadas na instituição e alguns de seus dados.
} 
espaço seja reestruturado com um novo projeto que seja um Memorial, pautado na Resistência dos militantes políticos, incluindo a mudança do nome, pois segundo eles, tudo o que não existiu naquele local foi liberdade. Foram solicitadas verbas no governo federal (Lei Rouanet), posteriormente incrementados por verbas estaduais. Em 2006, A Pinacoteca do Estado assume o ainda Memorial da Liberdade, pois o Arquivo do Estado passa da SEC para a pasta da Casa Civil. A reivindicação dos ex-presos políticos é reapresentada agora por Ivan Seixas e Maurice Politti, e acolhida em 2007, na gestão do diretor da Pinacoteca e Estação Pinacoteca, Marcelo Araújo. Este solicita a elaboração de um projeto museológico a uma equipe interdisciplinar. Este projeto foi submetido à apreciação dos ex-presos políticos que incluíram e discutiram as premissas, sobretudo pautada no enfoque da Resistência. O "Plano de Ocupação Museológica" foi aprovado pela Secretaria da Cultura em 2008. Em $1^{\circ}$ de maio de 2008 o nome é alterado para Memorial da Resistência, e ainda neste ano são contratadas equipes técnicas para criar e executar um novo projeto museológico no espaço. Os ex-presos políticos, a partir do Fórum de Ex-Presos e Perseguidos Políticos de São Paulo, são chamados a colaborar e participar do projeto de implantação do, a partir de então, Memorial da Resistência de São Paulo.

O MRSP é inaugurado em 2009, como um núcleo da Pinacoteca do Estado, geridos pela OS APAC (Associação Pinacoteca Arte e Cultura). Assim o Memorial divide espaço, administração e também recursos humanos com a Pinacoteca Luz e Estação Pinacoteca. Caracteriza-se por uma interessante composição, pois apesar de estar vinculada em todo seu gerenciamento, repasse de verbas da SEC, estrutura funcional, planejamentos de gestão e estratégicos da APAC, como um núcleo dentro do organograma da Pinacoteca, internamente, o MRSP funciona com a estrutura de uma instituição museológica, desenvolvendo programas de toda a cadeia. Possui Plano Museológico, Linhas de Ação ou Programas, e é classificado pela atual gestão, em sua fase de consolidação, e em gestação da terceira e última fase prevista em seu plano, que prevê a independência institucional do MRSP.

O Fórum de Ex Presos Políticos de São Paulo, por meio de seu núcleo Memória atua como parceiro do Memorial da Resistência na realização à ação cultural intitulada Sábados Resistentes, entre outras atividades, mas não participa da gestão do museu. Os Sábados Resistentes também foram uma reivindicação dos ex-presos políticos e tiveram início em 2008, antes da inauguração do Memorial da Resistência.

A comunidade de ex-presos políticos, em geral, participa nas atividades culturais promovidas pelo museu e como colaboradores dos programas tais como Ação Educativa (Rodas de Conversa), Ação Cultural (Sábados Resistentes), Pesquisa (Programa Coleta de Testemunhos e Programa Lugares da Memória).

Há um Conselho de Orientação Cultural para definição de políticas institucionais composto por pessoas ligadas ao tema, dos níveis do judiciário, secretarias públicas, comissão da verdade, especialistas em arquivo e museologia, e por um ex-preso político, integrante do Núcleo Memória e Fórum de Ex-Presos Políticos.

\section{2) Análise de PÚBLICO}

- Pesquisa de opinião + caracterização do público: faixa etária, estudantes, turistas, comunidade local, público alternativo. 


\section{1 - Público interno (ver equipe) \\ 2.2 - Público externo}

Público visitante presencial: Meta anual: $60.000 /$ Atingido: $72.811^{87}$

Faixa etária média de 35 anos (concentração em adolescentes e jovens até 30 anos).

Prepondera público feminino, escolaridade do ensino médio ao superior (maiores índices), solteiros, que exercem atividade remunerada.

As origens geográficas são equilibradas entre zonas da cidade, grande são Paulo e interior. Outros estados cobrem geralmente $10 \%$ dos visitantes. Outros países (turistas e estrangeiros) ficam na faixa de até $4 \%$.

Os meios de transporte utilizados pelo público são os públicos, com predomínio do metrô e ônibus.

Uma média de até $80 \%$ dos visitantes frequenta outros museus e visita o MRSP pela primeira vez, e quase a totalidade vem com acompanhante ou em grupos. Os visitantes conhecem o museu através de indicação de instituições de ensino, amigos/conhecidos e professores, TV, internet, e outros. Nos motivos da visita preponderam trabalhos escolares, atividades de estágio ou extracurricular de ensino básico, superior e pesquisa, passar ou trabalhar nas proximidades e Sala São Paulo, acompanhar grupos ou amigos, ou ainda interesse nos temas do Memorial da Resistência. Para o tempo de visita o maior índice está entre uma e duas horas de visitação.

\section{3) Levantamento de PARCEIROS}

Núcleo Memória - Fórum de Ex Presos Políticos do Estado de São Paulo

\section{4) Análise da ESTRUTURA disponível}

edifício / instalações; equipamentos; condições, etc.

O MRSP está instalado nos andares térreo (espaço expositivo, acolhimento de grupos) e primeiro andar (sala de trabalho) do edifício. Divide a edificação com a Estação Pinacoteca que ocupa todos os demais espaços, ficando em comum as áreas de acesso, circulação e serviços (bebedouros, banheiros, cafeteria, auditório). Sua área corresponde a $300 \mathrm{~m}^{2}\left(200 \mathrm{~m}^{2}\right.$ para exposição de longa duração e $100 \mathrm{~m}^{2}$ para as temporárias), para um público médio de quase 73 mil visitantes, sendo 25 mil deles atendidos em atividades educativas.

\footnotetext{
87 Conforme Relatório CONSOLIDADO 4o TRIMESTRE E ANUAL 2013 CONTRATO DE GESTÃO № 35 / 2008 RELATÓRIO ASSOCIAÇÃO PINACOTECA ARTE E CULTURA - APAC / ORGANIZAÇÃO SOCIAL DE CULTURA. UGE: UNIDADE DE PRESERVAÇÃO DO PATRIMÔNIO MUSEOLÓGICO. CONTRATO DE GESTÃO № 35 / 2008. Referente ao(s) museu(s): Pinacoteca do Estado de São Paulo (Pinacoteca Luz, Estação Pinacoteca e Memorial da Resistência de São Paulo). Disponível em http://www.pinacoteca.org.br/pinacoteca-

pt/Upload/file/Relatorio/Relat\%C3\%83\%C2\%B3rio\%20Consolidado\%204\%C3\%82\%C2\%BA\%20Trimestre \%20e\%20Anual\%202013.pdf).
} 
O espaço das celas não comporta o volume de grupos e visitantes espontâneos, falta espaço, conforto físico, térmico e formas de acomodação (mobiliário de descanso, por exemplo). Não há espaço para realização de atividades educativas e outros projetos desta área, que utiliza a própria exposição, a área externa ou outras salas e auditório do museu.

Falta sinalização interna. E ausência de sinalização externa indicativa do equipamento, desde as estações de metrô, incluindo a área do entorno, e na frente/porta do edifício. Muitos passam por ali todos os dias e não sabem lá está o MRSP.

Nas avaliações dos espaços e serviços do museu junto ao público informação, recursos, espaços e equipamentos, instalações e serviços oferecidos tem índices de satisfação normalmente elevados, com algumas ressalvas. Como dito, MRSP e Estação Pinacoteca partilham os serviços prestados e visíveis ao público, apresentação e manutenção geral de equipamentos e instalações físicas.

Iniciou em 2014 projeto para atendimento e adaptação dos espaços para acessibilidade a portadores de deficiências. Não possuem áudio-guias.

Os equipamentos necessitam de upgrade e ocorre de permanecerem certo tempo aguardando reparos ou substituições. Assim, ocorre de os visitantes encontrarem problemas com o projeção do vídeo da Cela 2, com o som dos áudios na última cela, e nos computadores do Centro de Referência (Terminal para consulta da documentação DEOPS no Memorial), como na ocasião da realização da pesquisa de público entre maio e junho de 2013, fato que os fez apontar problemas na exibição de alguns desses recursos.

Relacionados aos serviços e instalações os maiores índices são para: limpeza, recepção e entrada, acolhimento, atendimento nas salas de exposição, condições gerais do espaço e informações e explicações impressas disponíveis nas exposições (painéis, textos, folhetos).

A localização e entorno (Cracolância) inibe a frequentação de visitantes.

\section{5) Verificar EQUIPE disponível}

Equipe composta por:

1 gestor

1 coordenador de Ação Educativa

1 pesquisa sênior

2 pesquisadores contratados

1 Estagiário de comunicação

4 educadores

1 educador público especial

Demais necessidades e equipes: estrutura funcional APAC

Equipe de implantação:

Contratados: 1 museologa, 1 historiadora/educadora, 1 historiador pesquisador $+$

Consultoria: Historiadora, Museologia

$+$

Profissionais diversos para cada etapa do projeto: maquete, designer e expografia, comunicação visual/vídeos e entrevistas etc 
$+$

Profissionais Pinacoteca do Estado

\section{6) Análise da IMAGEM E CREDIBILIDADE DA INSTITUIÇÃO}

As exposições do Memorial da Resistência tem sempre níveis elevados e positivos de avaliação do público, chegando a atingir o total de 100\% em satisfação do público para a exposição de longa duração.

Os índices de recomendação do museu e retorno giram entre 90 e 100\%.

Referência para criação de outros espaços de memória congêneres.

É largamente procurado pela sociedade, como local de referência sobre o tema em vários níveis: estudantes, trabalhos acadêmicos, imprensa, cinema etc

Ganhou Certificado de Excelência 2014 do TripAdvisor pelo grande número de avaliações satisfatórias recebidas no site (Raking 64 de 111 das atrações de São Paulo no Trip Advisor)

Memorial da Resistencia de Sao Paulo

$20 \mathrm{~h}$.

Recebemos o Certificado de Excelencia 2014 do TripAdvisor pelo grande numero de avaliaçoes satisfatorias que recebemos no site. Agradecemos a todos os visitantes que nos avaliaram e deixaram seus comentarios.

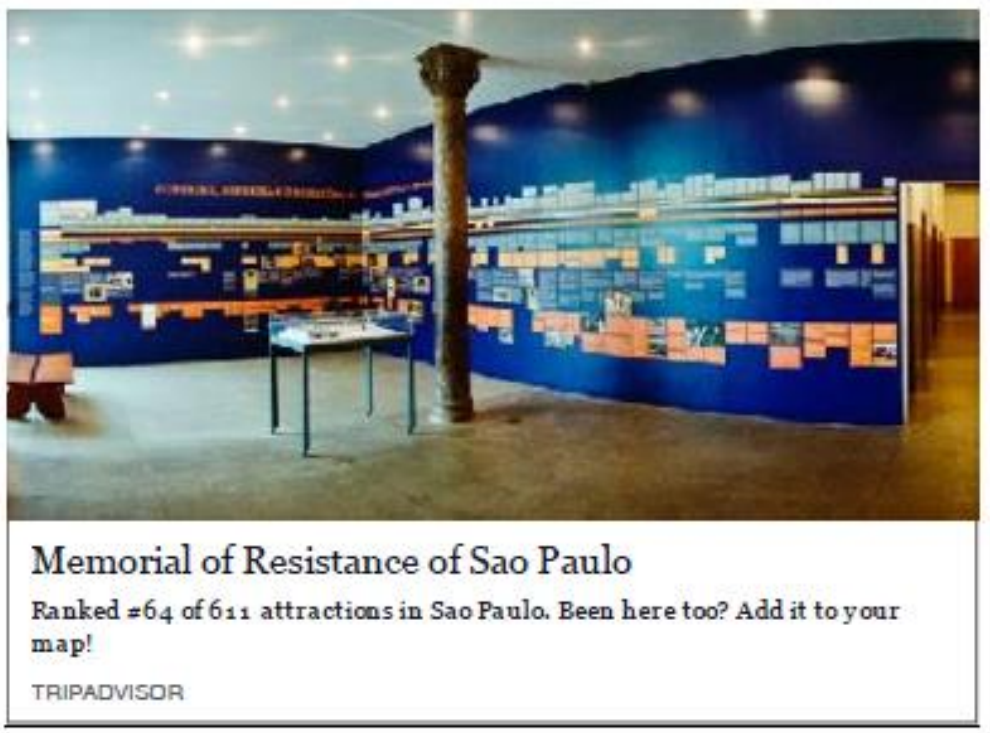

J'aime-Commenter-Partager - $\begin{array}{llll}35 & 2 & 3\end{array}$

\section{7) Análise de ACERVO (levantamento preliminar)}

Testemunhos orais, em registro audiovisual, suporte digital.

93 entrevistas realizadas entre 2008 e julho de 2014, sendo 88 entrevistados participantes.

Referências patrimoniais: testemunhos orais, inventário de lugares de memória e banco de referências a ser desenvolvido no Centro de Referência.

Histórico: A imaterialidade nasce na opção curatorial em construir uma narrativa a partir dos testemunhos e participação dos ex-presos, condição pré-definida pela forma como o projeto foi engendrado: pautado no tema e recorte da resistência política, chegou-se a conclusão que tudo deveria ser construído a partir de, e com base nas 
falas e memórias dos resistentes. No projeto de implantação, o museu não possuía espaço para armazenamento, e pessoal para tratá-lo, além de haver dúvidas sobre a pertinência de adquirir coleções, ponto que seria discutido posteriormente. Esta característica persiste e a definição de uma política institucional, com ou sem acervo, está prestes a ser iniciada junto ao Conselho de Orientação Cultural.

\section{8) Análise das funções museológicas (pesquisa, preservação e comunicação)}

Os programas estão bem delimitados e com projetos definidos. Seguem o escopo traçado no plano museológico. Todos os programas estão em funcionamento, com exceção do Centro de Referência, que é ainda o mais incipiente dentre todos. Existem fisicamente na exposição, mas não funciona como tal. As ações culturais e educativas são mais consolidadas, enquanto que os programas de pesquisa têm várias etapas e projetos em fases distintas de desenvolvimento.

As relações/interligação entre os programas são estabelecidas e colocadas como meta. Contudo, ainda não há um sistema de retroalimentação eficaz, onde os programas de pesquisa alimentem as ações dos demais programas, e entre si. Esta ligação precisa ser aprimorada. Os testemunhos tomados como base do conceito e projeto, não chegam ainda com tanta eficácia aos demais programas e na geração de produtos, informações históricas e geração de novos conteúdos. A produção ligada às exposições parte mais dos projetos de exposições temporárias e não o contrário. Falta um sistema de recuperação de dados, facilmente consultável, que estreitaria esta comunicação entre os programas de pesquisa e os demais programas. Necessita de aprimoramento das bases de dados dos programas de pesquisa, política institucional de acesso, metodologias e ferramentas de trabalho. Pode e deve consolidar/aprimorar os canais de comunicação e avaliação museológica, sobretudo na utilização de seus resultados no incremento de todas as ações. Plano museológico entre as fases dois e três de execução (consolidação e projeto de autonomia respectivamente).

\section{Prognóstico}

O museu exerce sua missão e aproveita bem seus pontos fortes. Um dos principais limitadores atuais é a falta de espaço. A Exposição da longa duração será atualizada durante do ano de 2015. Mas carece de espaço para as exposições, realização de ações e projetos educativos, e para expansão dos programas como um todo. Em verdade, para desenvolvimento de todo potencial e missão da instituição o museu deve ganhar autonomia e a respectiva estrutura (física, técnica, humana e financeira) para tal. Seu ápice está em chegar a ocupar todo o edifício do antigo Deops/SP, para então exercer sua missão e capacidades ao máximo. A possibilidade de autonomia segue em processo de elaboração conforme prevê o plano museológico. A expansão do espaço depende de decisões maiores. A atualização da exposição de 
longa duração poderá ser um primeiro passo de expansão. A atual gestão do MRSP espera que o pioneirismo de São Paulo, comprovado pela abertura do Acervo Deops para consulta pública, a criação do próprio Memorial e do Memorial da Diversidade, levem "tanto a Secretaria de Cultura quanto a Associação Pinacoteca Arte e Cultura não perca este referencial de vista e de possibilidades do Memorial crescer." 88 A falta de espaço, de mais recursos financeiros, técnicos/equipamentos e humanos podem ser considerados os atuais problemas ou limitadores da instituição na expansão de suas ações. Isto influi na ampliação de todas as ações/programas, e nos de pesquisa, mais recursos são condição de melhoria, carecendo de equipe maior e permanente para tratar o volume de informações geradas.

O museu está entre as prioridades para a comunidade de ex-presos políticos e é largamente reconhecido pelo público em geral, embora precise ganhar maior reverberação na sociedade, para que a partir dela, se criem demandas e novas possibilidades de expansão. Para ex-presos e sociedade são importantes tanto a reestruturação do MRSP, quanto a criação de novas instituições ou memoriais no tema, como forma de ampliação da educação em direitos humanos, da consciência política e da efetivação das políticas de memória e justiça.

Nas contribuições trazidas pelo museu mencionadas,

Pelos ex presos: "a maior e a mais importante iniciativa dos ex-presos políticos para revelar às novas gerações o que foi aquele período sombrio da nossa História. Para as escolas que não puderam ensinar, porque seus professores não puderam aprender, o Memorial será sempre um espaço inestimável para se valorizar a democracia, a dignidade humana e o valor da Liberdade"(Elias Stein, 2014). E "O que mais importante a oferecer aos visitantes do Memorial que a história do seu povo, a história da libertação de um período terrivelmente macabro e hediondo?" (Waldemar Rossi, 2014). E ainda: atingir a população ou parte dela por seus projetos e materiais educativos dirigidos ao público, dar chance de reflexão na história escondida por décadas. Por fim, "Sem sombra de dúvidas, o Memorial é rico de testemunhos, cujos, em muito acrescenta para que seus eventuais visitantes formem coerentes opiniões sobre a trágica trajetória política brasileira durante os anos 1964/1985." (Antonio Oliveira, 2014).

\footnotetext{
88 Fala de Kátia R. Felipini Neves, coordenadora do MRSP. Entrevista concedida em maio de 2014.
} 
Pelo público em geral: Conhecimento, informações históricas; memória; conhecer o passado; dar valor a democracia que temos hoje; visão dos presos; saber do sofrimento deles; revela a História do Brasil não contada em livros e filmes; amplia a reflexão a respeito da história; traz um pouco do que a gente não viveu; pra sentirmos como foi; informação para ter opiniões e ser atuante como cidadão; dar valor à democracia que vivemos hoje graças à luta de pessoas ainda não conhecidas e valorizadas por boa parte da população; possibilita o resgate e o uso da memória política da história do Brasil e um novo olhar para a questão da ditadura por relatos pessoais. Entre muitas outras.

E opiniões sobre melhorias,

\section{Pelos ex presos:}

"Não, acho que o Memorial conseguiu seus objetivos, e as pessoas que lá trabalham vão torná-lo cada vez melhor. Só espero que não faltem recursos técnicos e financeiros para os profissionais desenvolverem seus projetos."

"Apenas a elaboração didática dessa história e sua disponibilização para todo o povo brasileiro." (Waldemar Rossi, 2014), com os "recursos técnicos e financeiros para os profissionais desenvolverem seus projetos necessários" (Elias Stein, 2014), a retirada do espelho do corredor de sol, e as necessidades naturais de atualização pelo tempo, novas realidades e contextos sociais.

Pelo público em geral: melhorar sinalização (externa e interna), ampliar a divulgação, os conteúdos/temas, os recursos (fotos, depoimentos, salas, recursos multimídia, objetos, informações sobre os presos e também sobre opressores), documentos primários e arquivos do Deops, outras lutas e lugares, entre outros.

De acordo com a principal temática, linha de atuação, do museu e como isso reverbera nas ações de pesquisa, preservação e comunicação, avaliamos que se,

“(...) o eixo gerador das ações do Memorial e organiza em torno da exposição de longa duração, cuja concepção partiu do compromisso de restitui, às quatro celas remanescentes da antiga sede do DEOSP/SP, dignidade patrimonial, fazendo jus à importância da resistência política para a construção de caminhos democráticos e à relevância da reabilitação desse espaço para consolidação de estratégias educacionais a favor dos direitos humanos." Implantação do Programa Museológico. Catálogo MRSP. p. 61. 
Conclui-se que os Programas nascem da exposição para, a partir dela, continuar desenvolvendo outras ações. A exposição é o principio gerador dos programas, ao mesmo tempo que, estes ampliam a exposição, em conteúdos e em outros tipos de ações de comunicação ou difusão.

Se este foi um caminho fértil para fazer nascer e materializar o espaço de evocação dessas memórias, a revalidação do bem tombado e de temas de pertinência, constata-se agora a necessidade paulatinamente, deslocar este eixo, ou ao menos partilhá-lo organicamente com o Programa de Coleta Regular de Testemunhos. A evolução dos programas criou uma base importante de construção de conhecimento e geração de informações, bem como dinâmicas próprias. Os programas de pesquisa geram conhecimento, aprofundam e trazem informações inéditas, ou que complementam as já existentes. Um acervo de história oral já está constituído, com expressiva composição em quantidade e qualidade, muito certamente forma o maior no país no momento. Um novo fluxo de processos precisa ser criado de modo que os programas de pesquisa, com destaque para o coleta de testemunhos, sejam mais solidamente a base dos demais programas, onde eles se retroalimentem e criem novas ações. Eles também gerarão, por conseguinte, mais temas transversais para serem trabalhados nas ações educativas, culturais (seminários, sábados resistentes etc), e para as exposições em especial para as temporárias.

Para tanto os programas de pesquisa precisam consolidar as etapas de processamento técnico, documentação, catalogação e disponibilização dessas informações interna e externamente. Isso requer a expansão dos recursos humanos, técnicos e financeiros, tendo em vista inclusive o volume de informações a serem revistas, e a quantidade de testemunhos orais a verem seu processamento completado. Estes passos são primordiais para também desenvolver o Centro de Referência que não encontrou ainda possibilidade de ser efetivamente implantado.

Nesse sentido, o Programa Coleta Regular de Testemunhos assume função primordial, pois:

- Os testemunhos são a fonte principal e --- para o conhecimento e estudo da resistência e repressão nos períodos ditatoriais, dado o intencional "esfacelamento" da verdade histórica.

- Os testemunhos são forma de evidenciar a história através das pessoas que a protagonizou, sobretudo no que tange a história dos "vencidos", das microhistórias, do lugar de que todos são sujeitos históricos, conhecer a visão dos que resistiram e contraponto a historia oficial. 
- Os testemunhos são matéria e essência do patrimônio imaterial preservado no MRSP, sua razão de ser.

O Programa Coleta já constitui o maior acervo sobre o tema no Brasil, todavia ainda não está sendo utilizado e evidenciado em todo seu potencial. As informações geradas no programa ainda não migram para os demais programas em tempo real, como por exemplo, o programa de ação educativa, como modo de atualização de suas atividades, potencializando os Encontros com Educadores - uma outra forma de fazer chegar informações novas e atualizadas, ao público em geral, dada a função multiplicadora dos educadores. Assim como criar novos materiais pedagógicos, novas atividades educativas etc.

Outra questão pungente é a delimitação temática do Programa Coleta. Fez todo sentido focar os testemunhos coletados durante a implantação na reconstituição do Deops, em sua estrutura como órgão, as ações por ele impetradas e sua ocupação no edifício. Afinal, era a história de tudo isso que precisava ser comunicada e apresentada na reconfiguração do espaço. De lá pra cá, a linha norteadora do Programa continua sendo a localização de pessoas que passaram pelo Deops em diversas posições ou situações, com uma preocupação muito focada na continuidade de coleta de dados que permitam reconstituir a história do órgão e do edifício, durante sua permanência no mesmo.

A prática tem mostrado que este enfoque para a entrevista, num formato de história oral, acaba tornando a entrevista muito dirigida pela intervenção dos entrevistadores. E, muitas vezes, esta condução é ineficiente, e um tanto quanto esvaziada entre os demais assuntos abordados. Em grande parte dos casos vemos que as questões sobre o edifício, no momento da gravação, não atingem o objetivo esperado. Sobretudo no que diz respeito a detalhes arquitetônicos ou de fatos ligados ao cárcere e torturas. Entre as razões podem estar a evocação de memórias dolorosas, ou seja, ligadas ao momento em que a pessoa sofreu uma grave violação física, mental, ou emocional. Isto causa uma espécie de bloqueio dessas lembranças, que coincidem com os momentos de permanência no edifício e com as informações do espaço/tempo ali vividas, e que são acionadas quando buscamos descrições da prisão e dos espaços. A reincidência de uma questão que não foi respondida, na tentativa de alcançar mais detalhes, acaba por ser exaustiva e mesmo incômoda aos entrevistados. Há que se tomar bastante cuidado para que o roteiro com questões muito dirigidas, com a intenção de coletar informações, não torne a entrevista apenas 
um levantamento de informações. Percebemos ainda que proporcionar uma narrativa mais livre, inclusive no tema do cárcere, faz fluir melhor o desvelamento das memórias, que podem ser interrompidas quando se reforçam detalhes do edifício ou do órgão, e a insistência nos mesmos corta a sequência de memória e de narrativa da pessoa que dá seu testemunho. Em suma, detalhes muito precisos da reconstituição do prédio e do cotidiano da prisão costumam ser menores nas memórias evocadas, em volume e importância para os entrevistados.

É um importante momento para indagar os limites do programa e a dimensão do conhecimento que se deseja produzir. É preciso repensar o que importa colher sobre o período, sobre as ditaduras e contextos, intercontextos, tendo como parâmetro a realidade atual luta por justiça e a escassez de fontes como estas no Brasil, no tema e período. O foco no Deops/SP é uma contribuição importante e deve ser mantido no escopo conceitual do trabalho. Todavia, o alcance conceitual do programa merece ser ampliado. Ele pode abarcar mais temáticas de modo a captar visões mais amplas para a compreensão do período. E aprofundar o grande potencial presente na dimensão das experiências de vida ligadas à resistência e repressão, aprofundando como as trajetórias individuais se cruzam com vida coletiva/social, bem como suas contribuições no passado e presente na luta por causas sociais (melhora de vida geral, garantias de direitos, evolução democrática política etc). Essas seriam importantes pontes de ligação com o presente a explorar de diversas formas, com possibilidades de atrair mais tanto os próprios ex-presos políticos para falar de suas lutas atuais, como as demais gerações para proporcionar trocas mais efetivas com a ajuda do museu.

\section{Temas potenciais detectados nas entrevistas}

A experiência de dor ou memórias de dor

Debater, mostrar discutir na experiência humana traumas dolorosos infringidos por situações de violência e guerra, tortura, prisão e opressão física, moral e psicológica. Como o humano e por quais razões comete tais práticas, seus danos e formas de transformação dessa situação. (Neste ponto, ações diferenciadas podem congregar outros especialistas de estudos de comportamento humano, psicologia e outros).

Um leque aberto para a captação das experiências de luta e resistência

A oportunidade de narrativa aberta para descrição e registro das lutas de esquerda: movimentos, pessoas, fatos, organização e funcionamento de cada organização, estratégias, ações, e motivações.

Abre para a captação de eventos e fatos das micro-historias para compreensão maior da história coletiva dos períodos em questão. 


\section{PCRT - proposta de metodologia para as entrevistas}

A riqueza dos testemunhos será sempre inesgotável. Contudo, uma divisão temática, dividindo a entrevista em etapas de ao menos três sessões, aprimorando a qualidade da captação, a relação entre museu e colaborador, e seu conforto:

- 1 - Acolhimento, tomada das informações sobre o entrevistado, tomar dados da ficha técnica e memória. Conversa e preparação/discussão do roteiro

- 2 - Entrevista sobre a formação política e o contexto histórico / a organizaçãomilitância-ações /experiência de prisões e pós prisão ( implicações na vida pessoal , Exilio, Anistia, militância nesta fase)/ testemunho e memória(significados)

- 3 - Laboratório de aprofundamento: sobre o Deops/SP, com sensibilização da memória por meio de imagens, visita ao espaço expositivo e andares do edifício, alusão a outros relatos, e descrição de documentação cedida/doada pelo entrevistado. 


\section{CONSIDERAÇÕES FINAIS}

O objetivo proposto no início deste trabalho foi encontrar a(s) relação(ões) entre patrimônio imaterial e museus. Dentro desta perspectiva problematizamos a questão partindo do pressuposto de que os atores sociais e agentes da prática preservada devem ser identificados e incluídos em todo processo de musealização.

Trabalhando o objeto de estudo em vários níveis, dividimos a o problema central em três interpelações principais, a serem respondidas ao longo da pesquisa: Quais os efeitos da salvaguarda? Quais as consequências das ações de salvaguarda preservacionista? Ela contribui para o desenvolvimento humano, cultural, social, econômico, de uma localidade, ou território, e da comunidade que o ocupa?

O objetivo foi atingido em parte, pois mesmo levantando muitas questões e reflexões pertinentes muito resta a considerar dada a diversidade do patrimônio cultural imaterial. O resultado parcial foi acentuado pela especificidade do lócus de pesquisa analisado. Ele trouxe necessidades peculiares aos temas que the são inerentes e que mereceram atenção. Ao mesmo tempo, revelou a presença da imaterialidade em novos contextos e em novos tipos de museus. A realidade empírica mostrou que novos papéis vêm sendo atribuídos aos museus ou a processos patrimoniais, e que esses papéis se originam de demandas sociais de reconhecimento de memórias, direitos culturais, verdade e justiça.

Os museus estão cada vez mais ligados ao uso da memória de grupos. A memória vem sendo apontada pelo fazer museológico enquanto elemento intangível intrínseco a natureza de grupos sociais. Nesses contextos, o museu é colocado na condição de agente do processo de transformação social. A esta demanda, o museu vem promovendo novos modos de musealizar, normalmente pautados pela união das memórias à criatividade. Criam-se museus especialmente voltados à participação comunitária, aos direitos humanos e a memória frente a problemas da atualidade. Um dos mais prementes casos é a memorialização de espaços que denunciam violações impetradas pelo terrorismo de Estado no Brasil e no mundo. Estamos assistindo é a construção de projetos e museográficos e programas museológicos para essas memórias, para apresentá-las a comunidade. Centros de referência, inventários e a oralidade estão entre as metodologias. 
Esse alargamento do papel do museu exige-lhe um repensar constante, pois se defende que sua responsabilidade quanto à construção de narrativas, pode influenciar seu contexto social. E ao tratar de temas delicados ele pensa sobre o que deve oferecer em termos de reflexão histórica.

Isso implica em uma resignificação do patrimônio: a base para patrimonializar memórias de lutas e lugares a elas relacionados, só pode ser o caminho de definição das memórias como patrimônios humanos. A museologia compatível com tantas inovações e démarches são a museologia crítica, junto com os museus de comunidade. Estes abrem campo para perspectivas mais abertas, transcendendo as categorias tradicionais de coleção. Outros museus tratam os direitos humanos de forma mais ampla e baseiam-se no princípio da mudança de mentalidade e no valor social: o objetivo de educar a sociedade passa a dirigir o tratamento da coleção. Ela é usada sob o princípio da responsabilidade social, acima da tarefa de pesquisar e coletar tradicionais. São museus que constroem novos patrimônios, e o imaterial está presente com mais ênfase nesses museus.

O imaterial nestes museus revela uma nova tendência: o uso de testemunhos pessoais para contar a história. Os testemunhos carregam o valor da experiência para a transmissão de ensinamentos de uma geração à outra. Guardá-las tem o sentido maior de fazer um bem, guardar algo que ajudará as gerações seguintes. Pois o passado serve a entender o presente e pensar o futuro. Na forma de memórias, essas experiências transmitem uma herança comum.

O museu pode ainda não ser capaz de medir essa experiência. A experiência proporcionada pelo patrimônio imaterial está atrelada ao presente. Saber do passado alimenta o aprendizado do presente. Sob tais contornos o patrimônio ganha outro sentido, na medida em que é criado, transformado, usufruído. Mas para que isso aconteça depende da presença e participação da comunidade produtora do bem ou valor cultural. Na medida em que se torne o local de representação da prática cultural, o museu garante sua preservação viva, ou seja, dando condições para que a prática seja realizada e ao mesmo tempo vista/conhecida pelos demais, sem o risco de congelamento da prática ao ser submetida ao processo de preservação. 
A oralidade é tomada como ponto prioritário na Declaração da Diversidade Cultural ao patrimônio Oral, pois como vimos no caso da MRSP, ela pode ser a única forma de captar, preservar e transmitir o bem cultural em manifestação.

Em qualquer situação de referenciais patrimoniais imateriais, o reconhecimento do bem deve ser apontado pelos agentes que participaram dos fatos históricos em questão. E isso pode ser obtido apenas por meio de suas vozes e memórias. Daí ser conclusiva e imprescindível a coleta ininterrupta de seus testemunhos. Entre a característica mais relevante do imaterial está a capacidade de representação do grupo, dando espaço à suas identidades.

Outro passo está em criar mecanismos de transmissão, seja por sistemas de ensino formais e informais, com auxílio das tecnologias, mas sempre próximo e com participação das comunidades envolvidas. Pois só se preserva o que se ama, só se ama o que se conhece, como também já afirmou Aloísio Magalhães na defesa das referências culturais. Somente este envolvimento, de preferência intergeracional, pode manter vivo e protegido do desaparecimento a prática social, cultural ou de memória. O papel da cultura, da cultura popular, no desenvolvimento é defendido há muito, por Mario de Andrade e Aloísio Magalhães, e no mundo dos museus e do patrimônio por Hugues de Varine.

O Patrimônio imaterial, ao lidar com o presente do agora, traz latente o potencial de fazer crescer a riqueza inesgotável e incomensurável de cada ser humano. A preservação da memória traz vínculos, etapa evolutiva necessária à recuperação de valores, dar compreensão da situação presente, e ferramentas para todos para agirem favor da comunidade e lugar onde vivem. O redescobrir de valores, por sua vez, traz o potencial de desenvolvimento local, humano, social, cultural, integral.

N"o one could boldly assert that the soul (the intangible) can exist without the body (the tangible) and thus it can be argued philosophically and perhaps logically that the intangible and the tangible are two sides of the same coin... the accepted conclusions of the UNESCO World Commission on Culture and Development which unequivocally states that in any partnership of the tangible and the intangible, "The tangible can only be interpreted through the intangible' and not vice versa" (Dawson, 2000). ${ }^{89}$

\footnotetext{
${ }^{89}$ N"o poder-se-ia afirmar corajosamente que a alma (intangíveis) pode existir sem o corpo (tangível) e que, portanto, não pode ser alegado em termos filosóficos e talvez logicamente que o intangível e o concreto são as duas faces de uma mesma moeda... o aceite as conclusões da
} 
Do ponto de vista institucional buscamos identificar de que forma os testemunhos obtidos pelo Programa Coleta Regular de Testemunhos entram nas etapas e processos museológicos; como conteúdos, discursos e argumentos são apresentados; as propostas e metodologias de trabalho ou do fazer museológico, e a execução do plano museológico face às missões, valores e opções adotados pela instituição, estruturada nos moldes da cadeia operatória museológica e do conceito de museu.

As questões alvitadas para empreender a investigação da relação entre o imaterial e este museu foram:

- Este museu se afirma como imaterial? O público o reconhece dessa forma? Há necessidade do museu afirmar-se como imaterial, o que isso significa?

- Como o museu pode criar estratégias para se aproximar do público e trabalhar com todas as expectativas que lhe são inerentes? Como tratar esse tema no museu?

- Quem se beneficia deste museu, ou do Memorial da Resistência de São Paulo? Quem é o público que se beneficia direta ou indiretamente dele?

- Como os agentes se vêem representados? Como se vêem no museu?

- O que a exposição, ou de forma mais ampla, a visita ao Memorial da Resistência de São Paulo aciona nas pessoas? Como vêem o tema antes e depois da visita?

De todos os dados, observações e conversas com seus profissionais e públicos, vimos que não existe a formulação de um conceito de imaterial, ou a preocupação de enquadrar a atuação do museu na definição oficial desta categoria de patrimônio. $O$ imaterial é reconhecido no teor e natureza do bem musealizado, e portando, vivenciado na prática, ou na forma em que existe neste contexto. Para aqueles que realizam o trabalho de musealização o imaterial está nos testemunhos coletados, bem como na imaterialidade presente nos lugares de memória inventariados pelos programas de pesquisa, a começar pelo próprio edifício do antigo Deops onde o MRSP está situado, e que lhe dá forma e conteúdo.

Comissão Mundial da UNESCO sobre Cultura e Desenvolvimento, afirma inequivocamente que em qualquer parceria do tangível e do intangível, "o concreto só pode ser interpretada através dos intangíveis" e não vice-versa" (Dawson, 2000). 
Os públicos identificam o teor deste patrimônio ao ouvir os testemunhos e experenciá-los no espaço prisional, sem ter dimensão, contudo, de que eles se estendem para além da exposição, por meio de um programa permanente de coleta e registro de testemunhos dos ex- presos (as) políticos.

A engenhosidade da presença do patrimônio imaterial no MRSP reside na opção e maneira como ele foi constituído: fruto de reivindicação de um grupo detentor de um saber, a memória da resistência política, o espaço foi reconstituído de modo a representar suas estas memórias e, portanto, a identidade desse grupo de atores sociais (agentes da memória). O MRSP se insere na chave dos museus sem coleções ou acervos. Nesta nova tipologia de museu o eixo norteador está na narrativa construída em sua exposição de longa duração, local em que o bem imaterial, as memórias são extrovertidas ao público.

Como demonstrado ao longo do trabalho, a oralidade é, ao mesmo tempo, a referência patrimonial e a metodologia de sua patrimonialização. Vê-se, desta forma, a procedência das hipóteses levantadas neste estudo, no qual verificamos a oralidade na função base para a construção de um acervo, e base para uma referência patrimonial, para a pesquisa, e para a construção de processos museológicos. $\mathrm{Na}$ experiência estudada estes passos encontram total êxito.

Dois pontos de ressalva ou lacunas podem ser apontadas no processo de musalização: a necessidade de completar as etapas de processamento técnico e disponibilização dos testemunhos ao público; e a necessidade de consolidar o PCRT, seguido dos demais programas de pesquisa, para que ocorra, natural e sistemicamente, a sinergia entre todos os programas da cadeia museológica. Isto significa empreender a otimização do PCRT, pois ele é o veículo para a plena realização do conceito gerador museológico, bem como sua amplidão na relação com o contexto histórico subjacente, e seus reflexos no presente.

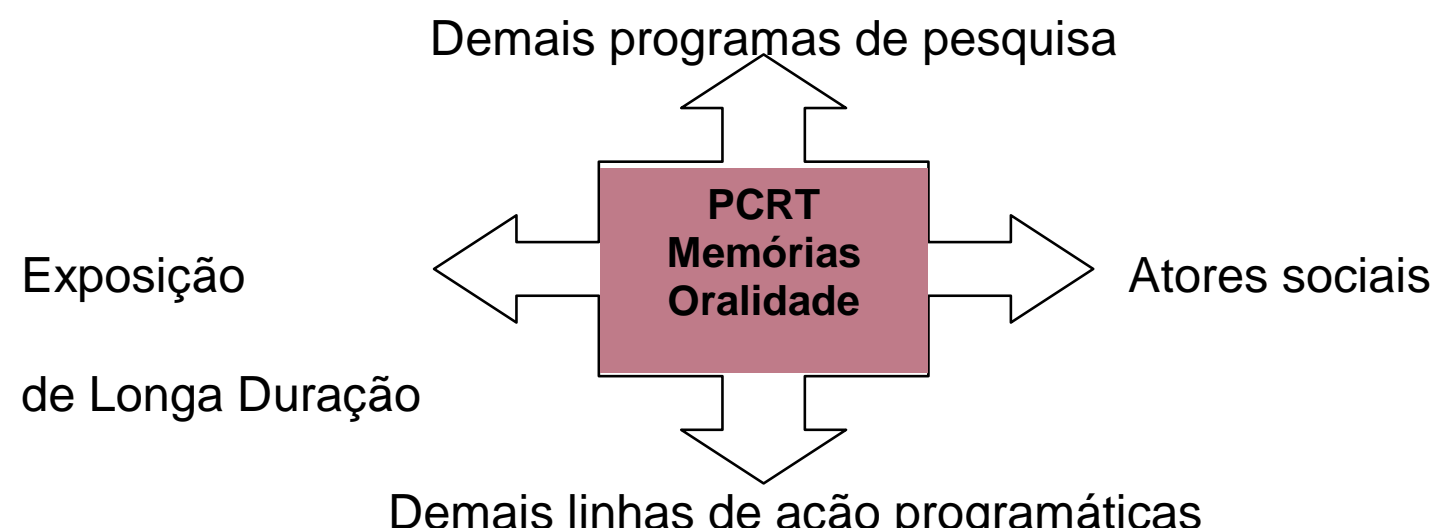


Quanto ao público (sociedade receptora) constatamos que a oralidade e a imaterialidade são captadas, antes de tudo, por meio do capital cultural individual e humano dos visitantes. Eles partilham da experiência dos ex-presos, alcançam paralelos destas experiências com sua própria realidade, onde o conteúdo informativo é unido a um conteúdo emocional bastante forte.

Por outro lado, o museu recebe uma procura muito ligada ao ensino formal e aos conteúdos do currículo do ensino formal. Inclusive, esta parece ser um fator preponderante nas visitações, utilizadas como instrumental para realização de trabalhos escolares e universitários. Fica então o desafio ao museu de conseguir ultrapassar esta demanda, transformando as visitas em possibilidades abertas de educação em espaços de memória, tornando o museu um lugar de encontro de interesses e práticas favorável à formação de consciências e empoderamento. A educação será sempre um fator chave nos "Museus Memoriais" ou Sítios de Consciência.

No que tange os atores e agentes da memória participantes do processo de musealização (no período de implantação ou na execução do PCRT), o MRSP é elo de ligação de um processo histórico inacabado. Todos auferem importância ao trabalho realizado pelo museu, que assume o papel das novas gerações de "redimir" essa história, contando sobre o passado, para que suas mazelas não se repitam e, principalmente, para que os jovens assumam o processo de transformações tão necessárias, e que lhes cabe, na continuidade do processo histórico.

A presença dos militantes no PCRT é considerada, por eles mesmos, quase um dever. É uma constante "obrigação" estar disponível para que essas verdades históricas sejam transmitidas. As lutas empenhadas no passado se transformaram em subsídios para novas formas de politizar e desenvolver a sociedade. Do ponto de vista da historiografia eles são fontes incontornáveis e insubstituíveis devido à escassez de outras fontes, forçadamente apagadas. Eles também revelam 0 conhecimento dos movimentos políticos e lutas de esquerda no período, sedento de aprofundamentos.

Percebemos nas falas dos ex-presos que contar e recontar sua história lhes proporciona a autorreflexão: sobre seu envolvimento dos fatos históricos, os reflexos desta atuação em suas vidas, sobre a conjuntura e como tudo aconteceu. Falar desta 
história para mais pessoas, em vários locais, para professores e jovens sobretudo, tem se tornado seu novo combustível e arma de luta pelas mudanças sociais desejadas.

O MRSP se tornou um lugar de referência no tema da ditadura para todos os públicos, uma referência na patrimonialização de memórias de dor e dos chamados sítios de consciência, e uma referência para os militantes da resistência do passado e militantes de direitos humanos no presente, onde se sentem representados.

Como uma das formas mais pungentes de aprendizado humano são as experiências passadas todos são beneficiados, direta e indiretamente, pelo que é apresentado no MRSP, enquanto local de referência para novas e antigas gerações.

O Memorial da Resistência apresenta o tema das ditaduras na história do Brasil. Seu recorte temporal cobre o início da República ao presente. Não é um museu histórico propriamente dito, mas um guardião de memórias. Entretanto, não escapa dos paradigmas inerentes aos museus históricos, na medida em que precisa problematizar as versões da história oficial. Contudo, com um peso muito maior, pois o MRSP acontece no próprio local onde tudo se fez para apagar e esconder a repressão política, durante e depois de sua existência. O edifício é ele mesmo, objeto/signo/símbolo deste esfacelamento da verdade histórica em toda sua trajetória.

Suas questões de fundo são a infração de direitos humanos, a violação do direito à vida e à justiça por questões políticas, ideológicas, econômicas. Toca o tema da justiça e reparação, temas delicados no Brasil, que mesmo com avanços nos últimos anos, permanece em grande atraso frente à reparação das vítimas, e da realização das reformas previstas na Justiça de Transição. Pontos que já conheceram muitos avanços em países da América Latina e do mundo, também vitimados por governos autoritários, ditaduras e fascismos.

O MRSP é por excelência o lugar de promoção da educação da sociedade, na especial tarefa de difundir princípios de paz, paridade, convivência harmoniosa e tolerância, verdade, igualdade de oportunidades, respeito, e criações que visem apenas o bem maior e comum. A educação para os direitos humanos já é prerrogativa e missão da instituição. Agora, resta avançar na expansão dessa prerrogativa, de modo que ela atinja mais pessoas em ações dentro da instituição, e outras que possam ser efetuadas extramuros, como ações fomentadoras e de formação, ou a oferta de assessoria, de editais e outros incentivos para ações locais. Neste sentido, a criação de um Centro de Educação em Direitos Humanos no organograma da instituição executaria tal missão com eficiência. Embora esta "benfeitoria" não caiba na 
estrutura atual, ela pode ser uma perspectiva realizável uma vez alcançada a autonomia institucional e a ampliação dos espaços físicos do MRSP.

Em outra perspectiva de ampliação do MRSP entendemos que seu papel social pleno será atingido na medida em que incluir os atores sociais nos demais processos da cadeia museológica e da gestão institucional. No ápice, seu modelo de gestão poderia migrar para um museu comunitário, participativo e de gestão compartilhada. Seu Conselho seria composto por um colegiado de ex-presos políticos em primeiro lugar, seguidos por representantes de vários setores da sociedade civil, e que incluam crianças e jovens. Este conselho seria consultivo e deliberativo, com papel primordial de levantar e atender necessidades e anseios da sociedade à qual se destina. Seria a possibilidade de criar um fórum aberto para debates e para a consulta pública de questões do museu e da atualidade.

Outra ampliação importante está na abertura ao público jovem, as gerações atuais, criando programas específicos para eles, oferecendo-lhes conteúdos das pesquisas, debates e reflexão por meio da ação educativa e ações culturais. Esta seria uma forma muito eficiente de ponte com as questões atuais, para que o Memorial seja de fato, um lugar, definitivamente, tão e somente de liberdade. Estes são caminhos mais próximos para que esse patrimônio seja um instrumento de desenvolvimento local integral.

Gonçalves Dias no seu poema Juca Pirama narra em versos a história do guerreiro Tupi, que para honrar sua tribo se entrega a tribo inimiga e a morte. A história é contada por um velho e suas memórias chamado Juca Pirama.

Assim como o índio tupi os militantes que resistiram à ditadura civil-militar se entregaram, mesmo cientes de todos os riscos que correriam, inclusive, passar pela tortura e pela morte. Eles doaram suas vidas daquele momento até o presente, pois mortos, desaparecidos ou sobreviventes eles interferiram definitivamente em seus destinos e de suas famílias, por doação a esta causa, afora os que nunca pararam e continuam mobilizados trabalhando pelas causas sociais.

Hoje, o tupi equivale a lugar dos militantes da resistência a ditadura, e Juca Pirama encarna no que pode ser e fazer o MRSP, nos contando essas histórias e memórias, que precisam e merecem ser honradas por todos nós. Elas são nossa herança e temos muito que aprender com elas. 


\section{Canção do Tamoio (Natalícia)}

Não chores, meu filho;

E pois que és meu filho, Não chores, que a vida É luta renhida:

Viver é lutar.

A vida é combate, Que os fracos abate, Que os fortes, os bravos Só pode exaltar.

Meus brios reveste;

Tamoio nasceste, Valente serás.

Sê duro guerreiro, Robusto, fragueiro, Brasão dos tamoios Na guerra e na paz.

VI

Um dia vivemos!

O homem que é forte

Não teme da morte;

Só teme fugir;

No arco que entesa

Tem certa uma presa, Quer seja tapuia, Condor ou tapir.

III

O forte, o cobarde

Seus feitos inveja

De o ver na peleja

Garboso e feroz;

E os tímidos velhos

Nos graves concelhos,

Curvadas as frontes,

Escutam-Ihe a voz!

IV

VIII

Domina, se vive;

Se morre, descansa

Dos seus na lembrança,

$\mathrm{Na}$ voz do porvir.

Não cures da vida!

Sê bravo, sê forte!

Não fujas da morte,

Que a morte há de vir!

Teu grito de guerra

Retumbe aos ouvidos

D'imigos transidos

Por vil comoção;

E tremam d'ouvi-lo

Pior que o sibilo

Das setas ligeiras,

Pior que o trovão.

VII

E a mão nessas tabas, Querendo calados

Os filhos criados

$\mathrm{Na}$ lei do terror;

Teu nome Ihes diga, Que a gente inimiga

Talvez não escute

Sem pranto, sem dor!

Porém se a fortuna, Traindo teus passos, Te arroja nos laços

Do inimigo falaz!

$\mathrm{Na}$ última hora

Teus feitos memora, Tranqüilo nos gestos, Impávido, audaz. 
IX

E cai como o tronco

Do raio tocado,

Partido, rojado

Por larga extensão;

Assim morre o forte!

No passo da morte

Triunfa, conquista

Mais alto brasão.

$\mathrm{X}$

As armas ensaia,

Penetra na vida:

Pesada ou querida,

Viver é lutar.

Se o duro combate

Os fracos abate,

Aos fortes, aos bravos,

Só pode exaltar. 


\section{REFERÊNCIAS}

ACCU - Report on conference on intangible cultural heritage and intellectual property under the 2003 Convention: seeking a collaborative interface between ICH and IP (New Delhi, India, 23 - 28 March 2007). Disponível em: http://www.accu.or.jp/ich/en/pdf/2007accu-kyushuuniv revised.pdf

ABREU, JOSÉ GUILHERME. Arte pública e lugares de memória. Revista da Faculdade de Letras, CIÊNCIAS E TÉCNICAS DO PATRIMÓNIO, Porto, 2005. I Série vol. IV, pp. 215-234

ALIVIZATOU, Marilena. 2012. Intangible heritage and the museum: new perspetives on cultural preservation. Walnut Creek: Institute of Archeology. Vol. 8, Critical cultural heritage series.225 páginas. ISBN: 978-1-61132-151-7.

ALMEIDA, Adriana Mortara e LOPES, Maria Margaret. Modelos de comunicação aplicados aos estudos de público de museus. Revista Ciências Humanas, Taubaté, v.9, n.2, p.137-145, jul-dez 2003.

ARANTES, A. A. Apresentação. In: Revista do Patrimônio Histórico e Artístico Nacional Brasília: no 32, 2005.

ARANTES, A. A. Patrimônio imaterial e referências culturais. Tempo Brasileiro, v. 1, n. 147, p. 129-139, 2001.

ARANTES, A. A. Sobre Inventários e outros Instrumentos de Salvaguarda do Patrimônio Cultural Intangível: Ensaios de Antropologia Pública: Anuário Antropológico 2007/2008: Rio de Janeiro, 2009.

ARANTES, Antonio Augusto (Org.). Produzindo o passado: estratégias de construção do patrimônio cultural. São Paulo: Brasiliense, 1984.

ARANTES. O patrimônio imaterial e a sustentabilidade de sua salvaguarda. Revista da Cultura. v. 7, p. 9-14, 2004.

ARRUDA, Beatriz Cavalcanti de. Diagnóstico do Serviço Educativo, Casas e Espaços da Memória da Divisão de Iconografia e Museus do DPH/SMC/PMSP: Bases para uma programação educativa em sistema. Monografia de conclusão de curso. Curso De Especialização Em Museologia. Museu De Arqueologia E Etnologia. Universidade De São Paulo. São Paulo, 2004.

BABELON, Jean-Pierre e CHASTEL, Andre. La notion de patrimoine. Paris: Liana Levi, 1994.

BENJAMIN, Walter. A obra de arte na época de sua reprodutibilidade técnica. In : BERGER, Peter e LUCKMAN, T. A construção da realidade. Petrópolis:Vozes, 1994. 
BORTOLOTTO, Chiara - La patrimonialisation de l'immatériel selon I'UNESCO [Paris]: Mission à l'ethnologie (Dapa, Ministère de la Culture), 2006. Disponível em: http://www.lahic.cnrs.fr/IMG/pdf/Bortolotto juin 06.pdf

BORTOLOTTO, Chiara; GRENET, Sylvie - Les pratiques des inventaires dans le cadre de la Convention de I'UNESCO . Paris: Institut National du Patrimoine, [2007]. Disponível em: http://www.inp.fr

BOURDIEU, Pierre. A Economia das Trocas Simbólicas. São Paulo: Perspectiva, 1987

BRANCO, Jorge Freitas - Significados esgotados: sobre museus e colecções etnográficas,2008.

Disponível em:https://repositorio.iscte.pt/bitstream/10071/1147/1/Branco Significados Donostia 2 $\underline{008 x . p d}$

BRITO, Ana Paula Ferreira De. O Tempo da Memória Política: (Re) Significando Os Usos Sobre a Memória do Período Militar no Brasil. Dissertação apresentada ao Programa de Pós-Graduação em Memória Social e Patrimônio Cultural - PPGMP da Universidade Federal de Pelotas, como requisito parcial à obtenção do título de Mestre em Memória Social e Patrimônio Cultural. 2014.

CANCLINI, Néstor García. Culturas híbridas. S. Paulo: Edusp, 1997.

CHARTIER, Roger. "Cultura popular: revisitando um conceito historiográfico". Estudos Históricos, Vol.8,n.16,1995, pp.179-192.

CHARTIER. "O mundo como Representação". Estudos Avançados, Universidade de São Paulo, Volume 5, n.11, 1991, pp. 173-191.

CHOAY, Françoise. A alegoria do patrimônio, São Paulo: Liberdade \& Unesp, 2001.

CLIFFORD, J. Colecionando arte e cultura. The Cultural Studies Reader, London: Routledge, 1993 (Trad. de Anna O. B. Barreto).

CLIFFORD, James. Museologia e contra-história: viagens pela Costa Noroeste dos Estados Unidos In: ABREU, Regina; CHAGAS, Mário (Orgs.) Memória e Patrimônio ensaios contemporâneos. Rio de Janeiro: DP\&A, 2003.

CARVALHO, Ana. Os Museus e o Património Cultural Imaterial: Estratégias para - Desenvolvimento de Boas Práticas Edições Colibri/CIDEHUS - Universidade de Évora Colecção: Biblioteca Estudos \& Colóquios, n.ำ 28, 2011.

CURY, Marília Xavier . Exposição - Concepção, Montagem e Avaliação. 2. ed. São Paulo: Annablume, 2008. v. 1. 162 p.

CURY, Marilia Xavier. Análise de Exposições Antropológicas - Subsídio para Uma Crítica. XIII Encontro Nacional de Pesquisa em Ciência da Informação - XIII ENANCI, 2012 . 
CURY,Marília Xavier. Comunicação museológica : uma perspectiva teórica e metodológica de recepção. São Paulo, 2005. Tese de Doutorado. São Paulo: ECA/USP, $366 \mathrm{p}$.

CURY. Museologia, Comunicação museológica e Narrativa indígena: a experiência do Museu Histórico e Pedagógico Índia Vanuíre -- Brasília : UnB/FCI, 2012. p.49-76. Disponível em: seer.bce.unb.br/index.php/museologia/article/view/6842/5514.

Deborah Regina Leal Neves. A persistência do passado: patrimônio e memoriais da ditadura em São Paulo e Buenos Aires. Dissertação apresentada ao Programa de Pós-Graduação em História Social do Departamento de História da Faculdade de Filosofia, Letras e Ciências Humanas da Universidade de São Paulo, para a obtenção do título de Mestre em História.2014.

DECCA, E. Salvadore de. O silêncio dos vencidos.São Paulo: Brasiliense, 1980.

Dominique Poulot. Le musée d'histoire en France entre traditions nationales et soucis identitaires. Anais do Museu Paulista. São Paulo. N. Sér. v.15. n.2.p. 293-316. jul.dez. 2007.

DUARTE, Alice - O desafio de não ficarmos pela preservação do património cultural imaterial. In SEMEDO, Alice; NASCIMENTO, Elisa Noronha - Actas do I Seminário de Investigação em Museologia dos Países de Língua Portuguesa e Espanhola. Porto: Universidade do Porto, 2010. ISBN 978-972-8932-61-9. Vol. 1, p. 41-61.

DUARTE, Geni; FROTSCHER, Méri; LAVERDI, Robson (Org.) História, Práticas Culturais e Identidades: abordagens e perspectivas teórico-metodológicas. Cascavel: Edunioeste, 2008 (prelo).

FALCÃO, A. (Org.). Registro e políticas de salvaguarda para as culturas populares. Rio de Janeiro: Centro Nacional de Folclore e Cultura Popular, IPHAN, 2005. (Série encontros e estudos; 6).

FALK, John Howard; DIERKING, Lynn Diane - Learning from museums: visitor experiences and the making of meaning. USA: AltaMira Press, 2000.

FERREIRA, Claudia Marcia. Cultura popular e políticas públicas. Texto apresentado no Seminário Patrimônio Cultural e Identidade Nacional em Brasília, setembro de 2001.

FIORIN, José Luiz. "Narratividade e discurso político". In: Encontro Nacional da Anpoll, 2.Rio de Janeiro, RJ, 1987, p.128.

FONSECA, M. C. L. O patrimônio em processo: trajetória da política federal de preservação no Brasil. Rio de Janeiro: Ed. UFRJ, IPHAN, 1997.

FONSECA, M. C. L. Referências culturais: base para novas políticas de patrimônio. In: IPHAN. Manual de aplicação do INRC. Brasília: MinC/IPHAN/Departamento de Documentação e Identificação, 2000. 
FREITAS, Henrique (et all). O método de pesquisa Survey. Notas \& Comunicações. Revista de Admininstração, São Paulo, V.35, n.03, pagina 105-112, julho/setembro 2000

GEERTZ, Clifford. A interpretação das culturas. Rio de Janeiro: Zahar. 1978. 323 p.

GONÇALVES, José Reginaldo Santos. A retórica da perda. Os discursos do patrimônio cultural no Brasil. Rio de Janeiro, Editora da UFRJ / IPHAN, 1996.

HAESBAERT, Rogério. O Mito da Desterritorialização: do "Fim dos Territórios" à multiterritorialidade. Rio de Janeiro: Bertrand Brasil, 2006

HAESBAERT, Rogério. Território e multiterritorialidade: um debate. GEOgraphia, v. 9, n. 17 , p. $19-44,2007$

HALBWACHS, Maurice. A memória coletiva. São Paulo: Edições Vértice. 1990.

HALL, Stuart. Identidade e diferença : a perspectiva dos estudos culturais. Tomaz Tadeu da Silva (org.); Stuart Hall, Kathryn Woodward ; traduções Tomaz Tadeu da Silva. Petrópolis:Vozes,2009. 133 p.

HARTOG, François. Tempo e Historia - Como escrever a historia da França hoje. Revista História Social. Campinas, n.3 , 127 -154, 1996

HARTOG, François. Tempo e Patrimônio. Temporality and Patrimony. VARIA HISTORIA, Belo Horizonte, vol. 22, no 36: p.261-273, Jul/Dez 2006. Tradução: José Carlos Reis/Departamento de História/UFMG. Disponível em: www.scielo.br/pdf/vh/v22n36/v22n36a02.pdf

HEINNEN, Johanna. Les Judisches Museum de Berlin et le paradoxe apparent des "Musées Identitaires". In: DE NOUVEAUX MODĖLES DE MUSÉES ? Formes et enjeux des créations et rénovations de musées en Europe XIXe-XXIe siècles. Anne-Solène Rolland et Hanna Murauskaya (dir.). Paris: L'Harmattan, 2009.

HOBSBAWM, Eric. A Invenção das Tradições. S. P. Paz e Terra, 1984.

Hooper-Greenhill, E. Museums and their Visitors. London: Routledge, 1994.

HUYSSEN, Andreas. Seduzidos pela memória. Arquitetura, monumentos e mídia. Rio de Janeiro: Aeroplano, 2000.

ICOM - Resolutions adopted by ICOM's General Assembly 2007 [s.l.]: ICOM, [2007]. Disponível em:http://icom.museum/resolutions/eres07.html ICOM - The role of International Council of Museums for the Safeguarding of Intangible Heritage. ICOM, $2009 . \quad$ Relatório. ICOM-ASPAC - Shanghai Charter. [Shanghai]: ICOM-ASPAC, October 2002. Disponível em:http://archives.icom.museum/shanghai charter.html

JADÉ, Mariannick - Le patrimoine immatériel, quels enjeux pour les musées? La Lettre du Comité National Français. n. 29 (2005), p. 13-16. 
JADÉ, Mariannick - Patrimoine immatériel: perspectives d'interprétation du concept de patrimoine. Paris: L'Harmattan, 2006.

LIMA FILHO, M. F.; ECKERT, C.; BELTRÃO, J. (Orgs.). Antropologia e patrimônio cultural: diálogos e desafios contemporâneos. Blumenau: Nova Letra, 2007.

MAGALHÃES, A. E Triunfo? A questão dos bens culturais no Brasil. Rio de Janeiro: Editora Nova Fronteira, 1997.

MAGNANI, José Guilherme. "Etnografia como prática e experiência". In: Horizontes Antropológicos, Porto Alegre: ano 15, n. 32, p. 129-156,jul./dez. 2009

Maria Laura de Viveiros Castro Cavalcanti e Maria Cecilia Londres Fonseca. Patrimônio imaterial no Brasil: legislação e políticas estaduais. Unesco e Instituto Brasileiro de Educação e Cultura, Educarte; 2008.

Manual de procedimentos do Programa de História Oral da Justiça Federal / Neide Alves Dias De Sordi; Gunter Axt; Paulo Rosemberg Prata da Fonseca. - Brasília : Conselho da Justiça Federal, 2007.

Memorial da Resistência de São Paulo. ARAUJO, Marcelo Mattos e BRUNO, Maria Cristina Oliveira (Coord.); NEVES, Kátia Filipini [et al.]. São Paulo: Pinacoteca do Estado, 2009. P. 61.

MAZÉ, Camille. Des musées de la nation aux musées de l'Europe. Vacilement, mantien ou renforcement d'un modèle?. In: Les Musées de la Nation. Créations, transpositions, renoveaux Europe XIXe-XXe siècles. Anne-Sollene Rolland et Hanna Murauskaya(dir.). L'Harmattan. 2010.

MORIN, Edgar. Saberes globais e saberes locais: 0 olhar transdisciplinar. $3^{a}$ ed. Rio de Janeiro: Garamond, 2001b. 76 p.

Museu e Museologia: Interfaces e Perspectivas/Museu de Astronomia e Ciências Afins - Organização de: Marcus Granato, Claudia Penha dos Santos e Maria Lucia de N. M. Loureiro . - Rio de Janeiro : MAST, 2009.

Museus e Património Imaterial: agentes, fronteiras, identidades. Coordenação: Paulo Ferreira da Costa. Edição: Instituto dos Museus e da Conservação e Softlimits, 2009. ISBN: 978-972-776-400-6.

Nora, Pierre. Les lieux de Mémoire. Paris: Gallirmard, 1984.3v.

OBSERVATÓRIO Itaú Cultural / OIC. Reflexões sobre indicadores culturais. -n. 4,(jan./mar. 2008). São Paulo, SP: Itaú Cultural, 2008.ORGANIZAÇÃO DAS NAÇÕES UNIDAS PARA EDUCAÇÃO, A CIÊNCIA E A CULTURA

O Direito à Memória: patrimônio Histórico e Cidadania, 1992, publicação resultante do Congresso Internacional Patrimônio Histórico e Cidadania, org DPH, SMC, ago 1991. 
Os Sambas, as Rodas, os Bumbas, os Meus e os Bois. A Trajetória da Salvaguarda do Patrimônio Cultural Imaterial no Brasil. Iphan. Brasília: Brasília Artes Gráficas, maio de 2006.

Os sambas, as rodas, os bumbas, os meus e os bois: princípios, ações e resultados da política de salvaguarda do patrimônio cultural imaterial no Brasil, 2003/2010. Brasília: IPHAN, 2010. 120 p. : il.

PELEGRINI, Sandra C. A. A gestão do patrimônio imaterial brasileiro na contemporaneidade. Revista História-UNESP, vol. 27, n. 02, p. 1-20, 2008 (prelo Dossiê Patrimônio Histórico). Qualis A- Internacional - Capes.

PERALTA, Elsa. A Memória do Mar Patrimônio, Tradição e (Re) imaginação Identitária na Contemporaneidade. Lisboa: Instituto Superior de Ciências Sociais e Política, 2008.

Revista Anistia Política e Justiça de Transição - Ministério da Justiça - N. 3. Brasília: Ministério da Justiça, jan./jun. 2010.

RIEGL, Aloïs - O culto moderno dos monumentos: sua essência e sua gênese. Goiânia:Editora UCG, 2006. Edição Francesa: Riegl, Alois. Le culte moderne des monuments: son essence et sa genèse. Paris, Seuil: 1984.

RODRIGUES, Marly. Imagens do Passado : A Instituição do Patrimônio em São Paulo. 1969-1987, 1999.

RUBINO. As fachadas da história. As origens, a criação e os trabalhos do SPHAN, 1936-1967, Ano de Obtenção: 1992. Mestrado em Antropologia Social (Conceito CAPES 5) . Universidade Estadual de Campinas, UNICAMP, Brasil.

RUSSIO, W. Conceito de cultura e sua inter-relação com o patrimônio cultural e preservação. In: Cadernos Museológicos. Rio de Janeiro, IBPC, (3):7-11, 1990.

SAHLINS, Marshall. O "pessimismo sentimental" e a experiência etnográfica: por que a cultura não é um "objeto" em via de extinção (parte II). Mana, Rio de Janeiro, v. 3, n. 2, out. $1997 . \quad$ Disponível em http://www.scielo.br/scielo.php?script=sci_arttext\&pid=S01043131997000200004\&lng=pt\&nrm=iso $>$. Acesso em 05 set. 2011. http://dx.doi.org/10.1590/S0104-93131997000200004.

SANT'ANNA, Márcia. Políticas públicas e salvaguarda do patrimônio cultural imaterial. In: IPHAN, Registro e políticas de Salvaguarda para as Culturas Populares. Série Encontros e Estudos $n^{\circ}$ 6, Rio de janeiro: IPHAN, CNFCP, 2ª edição, 2008.

TELES, Edson e SAFATLE, Vladimir (Org.). O que resta da ditadura: a exceção brasileira. São Paulo: Bointempo, 2010.Terra, 1978.

TIRADO SEGURA, Felipe. Contribuciones de la evaluación al desarrollo de la museología.In: ENCONTRO DE PROFISSIONAIS DE MUSEUS. A comunicação em 
questão:exposição e educação, propostas e compromissos. São Paulo; Brasília: MAE, USP: STJ,2003. p. 19-42.

TOLILA, Paul. Estadisticas, economia e indicadores culturales. El ejemplo francés y losavances europeus. Sistema de Informação Cultural. Republica Mexicana.

Disponível em<http://sic.conaculta.gob.mx/ficha.php?estado_id=0\&table=centrodoc\&table_id=41> . Acesso em 15 de maio de 2012.

UNESCO - Action plan for the safeguarding of the intangible cultural heritage as approved by the international experts on the occasion of the International Round Table on "Intangible Cultural Heritage - Working Definitions" organized by UNESCO in Piedmont, Italy, from 14 to 17 March 2001. [s.I.]: UNESCO, [2001] (161 EX/15 Annex). Disponível em:http://unesdoc.unesco.org/images/0012/001225/122585E.pdf

UNESCO - Convenção para a Salvaguarda do Património Cultural Imaterial. Paris: UNESCO, 2003.

UNESCO - Convenção sobre a Protecção e a Promoção da Diversidade das Expressões Culturais. Paris: UNESCO, 2005.

UNESCO - Decisions adopted by the Executive Board at its 167th session (Paris, 15 September-15 October 2003) [em linha]. Paris: UNESCO, 2003. (167 EX/Decisions) $\begin{array}{llll}\text { [Consult. } & 18 & \text { Jul. } & \text { 2008]. }\end{array}$ em:http://unesdoc.unesco.org/images/0013/001325/132529e.pdf

UNESCO - Declaração Universal sobre a Diversidade Cultural. Paris: UNESCO, 2001.

UNESCO - Declaration of Oaxaca (adopted at the Seminar on Education, Work and Cultural Pluralism, convened by UNESCO and the Mexican National Commission for UNESCO) [Oaxaca]: UNESCO, $1993 . \quad$ Disponível em:http://www.icomos.org/unesco/oaxaca.html

UNESCO - Definitions of intangible cultural heritage as of Member States, IGOs and NGO's. [s.l.]: UNESCO, [2001]. Disponível em: http://www.unesco.org/culture/ich/doc/src/00078-EN.pdf

UNESCO - Establishment of a system of "Living Cultural Properties" (Living Human Treasures) at UNESCO. Paris: UNESCO, 1993. Disponível em:http://unesdoc.unesco.org/images/0009/000958/095831EO.pdf

VALLE, Carlos Beltrão do: A patrimonialização e a musealização de lugares de memória da ditadura de 1964 - o Memorial da Resistência de SP. 371 pgs. Dissertação de Mestrado apresentada no dia 13 de agosto de 2012 no Programa de Pós-Graduação em Memória Social da Universidade Federal do Estado do Rio de Janeiro.

Varine, Hugues de. 2012. As raízes do futuro: o patrimônio a serviço do desenvolvimento local. Trandução de Maria de Lourdes Parreira Horta. Porto Alegre: Medianiz. 
VARINE. A Respeito da Mesa-Redonda de Santiago. In: ARAUJO, Marcelo e BRUNO, Maria Cristina Oliveira. A Memória do Pensamento Museológico Contemporâneo: Documentos e Depoimentos. São Paulo: Comitê Brasileiro do ICOM, 1995. P. 17-19

VASCONCELLOS, Camilo de Mello. Imagens da Revolução Mexicana. O Museu Nacional de História do México 1940 - 1982. São Paulo: Alameda Editorial, 2007.

VIEREGG, Hildegard K.; SGOFF, Brigitte; SCHILLER, Regina, ed. - Museology and intangible heritage II: International Symposium organized by ICOFOM, 20th general conference of ICOM, Seoul, Korea 2004: complete edition of the papers. München: Museums-Pädagogisches Zentrum, 2004. (ICOFOM Study Series 33 supplement). ISBN 3-929862-98-0. Disponível em: http://www.Irzmuenchen.de/ iims/icofom/iss33 supplement.pdf

VLACHAKI, Maria - Crossing cultures through the intangible heritage: an educational programme about migration in Greece. International Journal of Intangible Heritage. ISSN 1975-4019. Vol. 2 (2007), p. 93-102.

WALTER JAMIESON, Dean - Introduction to living heritage in the context of nature, Agri-, and eco-tourism. In UNESCO - Meeting report: UNESCO-EIIHCAP regional meeting - Safeguarding intangible heritage and sustainable tourism: opportunities and challenges. Hué: UNESCO [etc.], 2008. p. 85-87. Disponível em:http://www.unesco.org/culture/ich/doc/src/00349-EN.pdf.

WILLIAMS, Raymond. Cultura. Tradução Lólio Lourenço de Oliveira. Rio de Janeiro : Paz e Terra, 2000. $239 \mathrm{p}$.

WORCMAN, Karen [et al] - Identity and representation: social justice and community building through the Museums of the Person. In TRANT, J.; BEARMAN, D., ed. Museums and the web 2005: proceedings. Toronto: Archives \& Museum Informatics, 2005. Disponível em:http://www.archimuse.com/mw2005/papers/gillespie/gillespie.html

WORCMAN, Karen - The Museum of the Person. ICOM News. Vol. 57, n.ㅇ 3 (2004).

WORLD COMISSION ON CULTURE AND DEVELOPMENT - Our Creative Diversity: report of the World Comission on Culture and Development. Paris: UNESCO, WCCD, 1996. Disponível em:http://unesdoc.unesco.org/images/0010/001055/105586e.pdf

YAGUI, Mirian Midori Peres. Repressão, Luta e Resistência - o Memorial da Resistência de São Paulo. 2011. Monografia. (Aperfeiçoamento/Especialização em Gestão da Comunicação) - Universidade de São Paulo.

\section{Documentos}

Observatório de Museus e Centros Culturais (OMCC). Materiais utilizados na aplicação das pesquisas. Documentos do Observatório de Museus e Centros Culturais para pesquisa de público: "Perfil-Opinião de Museus e Centros Culturais. 2005-2007. http://www.fiocruz.br/omcc/cgi/cgilua.exe/sys/start.htm?sid=32\# 
IPHAN. Relatório final das atividades da Comissão e do Grupo de Trabalho Patrimônio Imaterial. In: O Registro do Patrimônio Imaterial. Dossiê final das atividades da Comissão e do Grupo de Trabalho Patrimônio Imaterial. Brasília: MinC/IPHAN/Funarte, 2006.

IPHAN. Patrimônio Cultural Imaterial para saber mais. Brasília: IPHAN/MinC, 2007.

IPHAN. Programa Nacional do Patrimônio Imaterial. Brasília: IPHAN/MinC, $3^{\underline{a}}$ ed. 2008.

UNESCO. Obras Maestras del Patrimonio Oral e Inmaterial de la Humanidad Proclamaciones 2001, 2003 y 2005. CLT/CH/ITH/PROC/BR3.

DIARIO OFICIAL ESTADO SÃO PAULO. Resolução D.O. Tombamento DOI-Codi.

\section{Acervo Memorial da Resistência de São Paulo}

Atualização de roteiro de entrevista. Programa Coleta Regular de Testemunhos do Memorial da Resistência de São Paulo. PCRT/MRSP. (provável 2013, s/d)

Base de Dados entrevistados. PCRT/MRSP. Julho 2014.

Base de dados entrevistas. PCRT/MRSP. Julho 2014.

Memorial da Resistência de São Paulo. Avaliação de Público. Segundo Trimestre de 2013. Relatório Final. Equipe Memorial da Resistência de São Paulo, Junho de 2013.

Memorial da Resistência. Programa Coleta de Testemunhos. Manual de Procedimentos de Pesquisa. 2013.

Plano Museológico. Elaborado por BRUNO, Maria Cristina Oliveira; ARRUDA, Beatriz Cavalcanti; FIGOLS, Franscisca Aida Barbosa. Memorial da Resistência de São Paulo, Associação Pinacoteca Arte e Cultura/Pinacoteca do Estado. São Paulo, 2010.

RELATÓRIO Avaliação da experiência da visita Pinacoteca Do Estado (Luz), Estação Pinacoteca, Memorial Da Resistência. ADM Museologia e Educação Ltda. Dezembro de 2012

Relatório de atividades Memorial da Resistência de São Paulo 2009 a 2013. Conselho de Orientação Cultural. APAC/MRSP. Janeiro de 2014.

RELATÓRIO Final. Pesquisa de Satisfação Pinacoteca do Estado de São Paulo, Fundação Getúlio Vargas. Júnior Pública FGV. Dezembro de 2012.

Resumo Roteiro Entrevista ex-presos políticos. PCRT/MRSP. 2014

Resumo Roteiro Entrevista ex-presos políticos. PCRT/MRSP. 2014.

Roteiro de entrevista de Maria José Soares. PCRT/MRSP. 25/07/2014.

Roteiro de entrevista Padrão 2012. PCRT/MRSP. 
Roteiro de entrevista Padrão 2013. PCRT/MRSP.

Roteiro de entrevista Padrão 2013. PCRT/MRSP.

\section{Fontes Orais}

Acervo Memorial da Resistência de São Paulo: Entrevistas sobre militância, resistência e repressão durante a ditadura civil-militar. Memorial da Resistência de São Paulo, entrevista concedidas a Equipe do Memorial da Resistência. Período 2012 a julho de 2014.

ALMEIDA, Leane. Entrevista sobre militância, resistência e repressão durante a ditadura civil-militar. Memorial da Resistência de São Paulo, entrevista concedida a Karina Alves e Marcela Boni Evangelista em 23/07/2013.

AMANO, Takao. Entrevista sobre militância, resistência e repressão durante a ditadura civil-militar. Memorial da Resistência de São Paulo, entrevista concedida a Karina Alves em 10/06/2014.

ANTONIO DE SOUZA, Ismael. Entrevista sobre militância, resistência e repressão durante a ditadura civil-militar. Memorial da Resistência de São Paulo, entrevista concedida a Karina Alves em 14/02/2014.

ARANTES, Maria Auxiliadora de Almeida Cunha. Entrevista sobre militância, resistência e repressão durante a ditadura civil-militar. Memorial da Resistência de São Paulo, entrevista concedida a Karina Alves e Marcela Boni Evangelista em 22/5/2013.

BERNACCHIO, Alberina. Entrevista sobre militância, resistência e repressão durante a ditadura civil-militar. Memorial da Resistência de São Paulo, entrevista concedida a Karina Alves e Marcela Boni Evangelista em 04/10/2013.

CARVALHO, Derly. Entrevista sobre militância, resistência e repressão durante a ditadura civil-militar. Memorial da Resistência de São Paulo, entrevista concedida a Karina Alves e Marcela Boni em 18/10/2013.

CASTRO, Cloves de. Entrevista sobre militância, resistência e repressão durante a ditadura civil-militar. Memorial da Resistência de São Paulo, entrevista concedida a Karina Alves e Marcela Boni Evangelista em 12/06/2013.

COELHO, Lúcia Maria Salvia Coelho e COELHO, Sérgio Salvia. Entrevista sobre militância, resistência e repressão durante a ditadura civil-militar. Memorial da Resistência de São Paulo, entrevista concedida a Karina Alves e Paula Salles em 24/06/2014.

COSTA, Maria Aparecida. Entrevista sobre militância, resistência e repressão durante a ditadura civil-militar. Memorial da Resistência de São Paulo, entrevista concedida a Karina Alves e Paula Salles em 13/06/2014.

CYRILLO, Manoel. Entrevista sobre militância, resistência e repressão durante a ditadura civil-militar. Memorial da Resistência de São Paulo, entrevista concedida a Karina Alves e Marcela Boni Evangelista e Kátia Filipini. 26 de julho de 2013 e 16 de agosto de 2013. 
DOWBOR, Adílio. Entrevista sobre militância, resistência e repressão durante a ditadura civil-militar. Memorial da Resistência de São Paulo, entrevista concedida a Karina Alves e Marcela Boni Evangelista em 17/04/2013.

FREIRE, Alípio Raimundo Viana; SEIXAS, Ivan; POLITI, Maurice. Entrevista sobre militância, resistência e repressão durante a ditadura civil-militar. Memorial da Resistência de São Paulo, entrevista concedida a Marcelo Araújo, Cristina Bruno e Kátia Neves em 11/09/2008.

LOBO, Elza; NOGUEIRA, Rose. Entrevista sobre militância, resistência e repressão durante a ditadura civil-militar. Memorial da Resistência de São Paulo, entrevista concedida a Maurice Politi, Kátia Neves e Marcelo Araújo em 16/09/2008.

LOBO, Pedro. Entrevista sobre militância, resistência e repressão durante a ditadura civil-militar. Memorial da Resistência de São Paulo, entrevista concedida a Karina Alves e Marcela Boni Evangelista em 16/10/2013.

LOBO, Pedro. Entrevista sobre militância, resistência e repressão durante a ditadura civil-militar. Memorial da Resistência de São Paulo, entrevista concedida a Karina Alves e Marcela Boni Evangelista em 16/10/2013.

LOPES, Guiomar Silva. Entrevista sobre militância, resistência e repressão durante a ditadura civil-militar. Memorial da Resistência de São Paulo, entrevista concedida a Karina Alves e Paula Salles em 08/04/2014.

MIYAKI, Darci Toshiko. Entrevista sobre militância, resistência e repressão durante a ditadura civil-militar. Memorial da Resistência de São Paulo, entrevista concedida a Karina Alves e Ana Paula Brito em 24/04/2014.

OLIVEIRA, Antonio. Entrevista sobre militância, resistência e repressão durante a ditadura civil-militar. Memorial da Resistência de São Paulo, entrevista concedida a Karina Alves e Marcela Boni Evangelista em 23/10/2013.

OLIVEIRA, Jorge Luiz Santos. Entrevista sobre militância, resistência e repressão durante a ditadura civil-militar. Memorial da Resistência de São Paulo, entrevista concedida a Karina Alves e Paula Salles em 23/04/2014.

PADILHA, Anivaldo. Entrevista sobre militância, resistência e repressão durante a ditadura civil-militar. Memorial da Resistência de São Paulo, entrevista concedida a Karina Alves e Marcela Boni em 30/08//2013.

PAIVA, José; MARTINELLI, Rafael. Entrevista sobre militância, resistência e repressão durante a ditadura civil-militar. Memorial da Resistência de São Paulo, entrevista concedida a Maurice Politi, Ivan Seixas e Kátia Neves em 18/09/2008.

ROIG, Vicente Eduardo Gomes. Entrevista sobre militância, resistência e repressão durante a ditadura civil-militar. Memorial da Resistência de São Paulo, entrevista concedida a Karina Alves e Paula Salles em 15/04/2014.

ROQUE, Adílio. Entrevista sobre militância, resistência e repressão durante a ditadura civil-militar. Memorial da Resistência de São Paulo, entrevista concedida a Karina Alves e Marcela Boni Evangelista em 17/04/2013. 
ROQUE, Ladislau. Entrevista sobre militância, resistência e repressão durante a ditadura civil-militar. Memorial da Resistência de São Paulo, entrevista concedida a Karina Alves e Marcela Boni Evangelista em 7/02/2014.

ROSSI, Waldemar. Entrevista sobre militância, resistência e repressão durante a ditadura civil-militar. Memorial da Resistência de São Paulo, entrevista concedida a Karina Alves e Marcela Boni em 18/09/2013.

SANTOS, Maria Aparecida. Entrevista sobre militância, resistência e repressão durante a ditadura civil-militar. Memorial da Resistência de São Paulo, entrevista concedida a Karina Alves e Marcela Boni Evangelista em 11/10/2013.

SILVA, Ilda Martins da. Entrevista sobre militância, resistência e repressão durante a ditadura civil-militar. Memorial da Resistência de São Paulo, entrevista concedida a Karina Alves e Paula Salles em 18/03/2014.

SILVESTRE, Vicente. Entrevista sobre militância, resistência e repressão durante a ditadura civil-militar. Memorial da Resistência de São Paulo, entrevista concedida a Karina Alves e Paula Salles em 22/04/2014.

SIPAHY, Rita. Entrevista sobre militância, resistência e repressão durante a ditadura civil-militar. Memorial da Resistência de São Paulo, entrevista concedida a Kátia Neves em 18/03/2013.

SOUZA BOM, Djalma. Entrevista sobre militância, resistência e repressão durante a ditadura civil-militar. Memorial da Resistência de São Paulo, entrevista concedida a Karina Alves em 13/02/2014.

STEIN, Elias. Entrevista sobre militância, resistência e repressão durante a ditadura civil-militar. Memorial da Resistência de São Paulo, entrevista concedida a Karina Alves em 06/09/2013.

SZERMTA, Stanislaw. Entrevista sobre militância, resistência e repressão durante a ditadura civil-militar. Memorial da Resistência de São Paulo, entrevista concedida a Karina Alves e Marcela Boni Evangelista em 27/9/2013.

ULRICH, Emilio Ivo. Entrevista sobre militância, resistência e repressão durante a ditadura civil-militar. Memorial da Resistência de São Paulo, entrevista concedida a Karina Alves e Vanessa Amaral em 13/09/2013. 


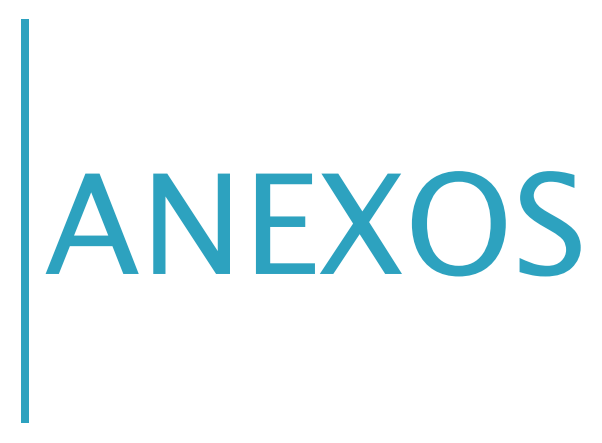




\section{Conceito Gerador}

"O histórico do DEOPS e a trajetória de ocupação do edifício em pauta indicam que este conceito gerador deve priorizar as seguintes características:

Evidenciar os vetores de memória, de uma instituição de controle do exercício da cidadania, a partir da musealização dos espaços da repressão e da resistência, como expressões do Estado Moderno;

Difundir a importância da preservação dos vestígios da memória, a partir da pesquisa, salvaguarda e comunicação das fontes e indicadores desta herança patrimonial;

Problematizar os distintos caminhos da memória da repressão e da resistência, enfatizando as estratégias de controle de um Estado Republicano e tendo como referência a ação do DEOPS no estado de São Paulo, a partir dos seguintes segmentos: memórias silenciadas / apagadas / destruídas / exiladas; pesquisas sobre a construção da memória e memória e herança patrimonial;

Atualizar as questões relativas à repressão e resistência para os dias atuais". (Bruno; 2010, p.46)

\section{Missão}

0 Memorial da Resistência de São Paulo tem com missão a pesquisa, a salvaguarda e comunicação de referências das memórias da resistência e da repressão políticas do período republicano brasileiro, tendo como sede o edifício que abrigou o Departamento Estadual de Ordem Política e Social de São Paulo - Deops/SP, de forma a contribuir para a reflexão crítica acercada história contemporânea do país e pra a valorização de princípios democráticos, do exercício da cidadania e da conscientização sobre os direitos humanos. (Bruno; 2010, p.47)

\section{Visão}

Assegurar a permanência do debate sobre as memórias da resistência e da repressão políticas, permitindo a valorização da preservação de suas referências patrimoniais, contribuindo para a educação permanente dos cidadãos e possibilitando a qualificação da coexistência institucional com a Pinacoteca do Estado. (Bruno; 2010, p.47)

Os valores institucionais são extensos e podem ser resumidos nos 10 pontos a seguir:

Valorização patrimonial do lugar de memória, edifício do antigo Deops/SP, que remete diretamente à temática da repressão e da resistência políticas;

Pesquisa, salvaguarda e comunicação das referências das memórias da resistência e da repressão políticas, por meio da gestão de informações atualizadas, de exposições e de ações educativas e culturais;

Estímulo ao respeito às diferentes manifestações de resistência políitica, por intermédio da aproximação e articulação dos respectivos grupos, instituições e associações ligadas à temática central do Memorial da Resistência;

Incentivo à compreensão das manifestações atuais de resistência e de repressão valorizando a democracia, a cidadania e os direitos humanos, contribuindo para a formação de cidadãos críticos e atuantes;

Desenvolvimento de ações educativo-culturais voltadas à mobilização perceptiva, emotiva e cognitiva para os diferentes públicos, estimulando a reflexão crítica em relação aos direitos humanos, às diferentes manifestações de resistência e às práticas autoritárias;

Realização de experimentações museais inéditas, colaborando com a ampliação do campo de reflexão museológica;

Projeção das reciprocidades entre história e arte, a partir das perspectivas de coexistência institucional;

Possibilidade de agregar valor à Pinacoteca de Estado mediante a potencialidade de ações museológicas comuns;

Proposição de modelo museológico (lugar da memória + conceito gerador + linhas de ações programáticas) para 0 tratamento da memória sobre problemas políticos do Brasil contemporâneo.

Com base no Plano Museológico (Bruno; 2010, p.48) 
O Memorial da Resistência de São Paulo, por meio de seu Programa de Coleta Regular de Testemunhos, é foco de análise da pesquisa de mestrado "O Patrimônio Imaterial sob a ótica dos museus:novas aproximações, perspectivas e rupturas." Este questionário alimentará os dados dessa pesquisa e necessita do seu auxílio, e insubstituível ponto de vista- sem o qual nossas análises não estarão completas.

Suas respostas serão apresentadas em anexo do original da dissertação de mestrado mediante sua expressa autorização.

Gratidão e reconhecimento,

A pesquisadora Karina Alves Teixeira

1) Como se deu sua aproximação e participação junto ao Memorial da Resistência de São Paulo?

2) Você participou e/ou participa de quais ações/projetos/eventos do museu?

3) O que significou/a, para você, esta participação?

4) Ela trouxe reflexos para sua vida no presente? Quais? De que forma? E em quais campos?

5) Por que aceitou dar sua contribuição?

6) Você sente sua história/trajetória contemplada no Memorial da Resistência? De que forma?

7) Você enxerga sua história e memórias como um patrimônio? E a de seu grupo de militância?

E a história da resistência/repressão do Golpe Civil-Militar (1964-1985)?

8) O que espera como resultado da entrevista cedida ao Memorial da Resistência?

8.1 - Indicaria algum modo ou forma para que ela seja trabalhada?

9) Em sua opinião, o que o Memorial da Resistência de São Paulo oferece à sociedade e aos

seus visitantes?

10) Para você, há algo a ser acrescentado e/ou modificado no Memorial da Resistência?

11) Em seu entender, qual o papel de Memoriais ou Centros de Memória sobre a ditadura?

Eles proporcionam alguma forma de reparação? 


\section{A) Implantação}

- Processo que envolve a decisão de criação da instituição pelo órgão público e o processo de participação dos ex-presos políticos.

- participação de outros ex-presos

-contexto de criação na época

- As decisões de trabalhar com memórias e o intangível. De onde extraíram referencial para a elaboração do projeto com tais características.

- Pensaram na nomenclatura de patrimônio cultural imaterial naquela ocasião?

\section{B) Gestão e desenvolvimento}

Em que ponto considera que se encontra o desenvolvimento da instituição. Em relação:

- plano museológico,programas, projetos etc

- aos ex-presos e familiares

- público em geral

- a Sociomuseologia

\section{C) Mudanças}

- faria mudanças em algum ponto seja do Plano, da Gestão, ou outra que queira apontar?

- Como toda instituição museológica, o MRSP está em permanente desenvolvimento. O que você considera que falta ao Memorial hoje?

- Há algo que acrescentaria tendo em vista o percurso percorrido até aqui?

- E quais as perspectivas enxerga para o MRSP?

\section{D) O Imaterial}

- Qual o bem imaterial preservado no MRSP? De que forma se associa ao patrimônio imaterial?

- Como o imaterial está presente no MRSP?

- De que forma isso é mostrado ao público?Você acredita que militantes e público em geral relacionam o museu ao patrimônio cultural imaterial? 


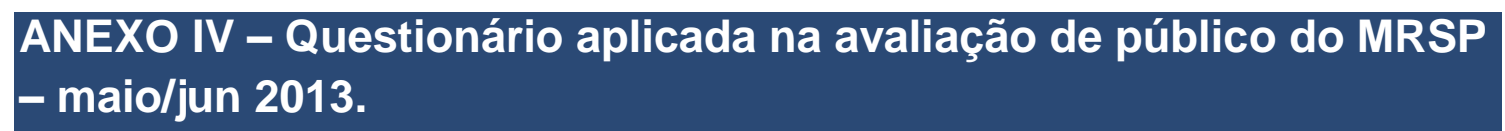

Memorial da Resistência de São Paulo - Avaliação de Perfil e Satisfação de Público

Data:______ Dia da semana: DSTQQS Período: Pesquisador:

\section{Tipo de Visita:}

a - Espontânea

b - Educativa*

* Levar em conta que há uma dinâmica própria e que o grupo é trazido pelo professor, acompanhado por um educador

\section{Espaço visitado:}

a - Exposição de Longa Duração

b - Exposição Temporária

\section{Sexo: [NÃO PERGUNTAR!]}

a - Feminino

$\mathrm{b}$ - Masculino

4. Idade: (anos completos)

\section{Estado civil:}

a - Solteiro(a)

b - Casado(a) / união estável

c - Viúvo(a)

d - Separado(a) / divorciado(a)

e - Outro:

6. Você exerce alguma atividade remunerada?

$a$ - Não $\quad b-\operatorname{Sim}$

7. Qual sua situação ou vínculo empregatício?

a - Empregado do setor privado

b - Empregado do setor público

c - Profissional liberal

d - Autônomo / por conta própria

e - Empresário

f - Bolsista / estagiário

g - Outra:

\section{Qual sua Profissão?}

9. Qual o seu grau de instrução (Escolaridade)?

a - Sem instrução escolar

b - Ensino Fundamental incompleto

c - Ensino Fundamental completo

d - Ensino Médio incompleto

e - Ensino Médio completo

f - Ensino Superior incompleto

$\mathrm{g}$ - Ensino Superior completo

h - Pós-graduação / Mestrado / Doutorado

10. Em que Bairro/Cidade/Estado/País você mora? 
11. Qual foi o meio de transporte utilizado para a visita? [PODE MARCAR MAIS DE 1 RESPOSTA]

a - Metrô

b - Ônibus

c - Carro

d - Trem

e - Outros:

12. Você veio acompanhado(a) hoje? [SE NÃO, PULAR PARA A PERGUNTA 14!]

a - Não, estou sozinho(a)

b - Sim, estou com 1 pessoa

c - Sim, estou com 2 a 3 pessoas

d - Sim, estou com 4 ou mais pessoas

13. Com quem você está visitando o Museu? [PODE MARCAR MAIS DE 1 RESPOSTA]

a - Com o cônjuge / companheiro(a) ou namorado(a);

b - Com pai / mãe;

c - Com um ou mais filhos;

d - Com outros membros da família;

e - Com amigos;

f - Com um grupo organizado (igreja, escola, etc.)

Qual?

g - Outros:

14. Você costuma visitar museus?

a- Não $\quad$ b - Sim / Quais os últimos visitados?

b.1.

b. 2 .

b. 3

b.4.

15. É a primeira vez que você visita o Memorial da Resistência de São Paulo?

a - Não / Quantas visitas realizou antes desta?

$\mathrm{b}-\mathrm{Sim}$

16. Você sabe que neste edifício funcionam dois museus?

$a$ - Não $\quad b-\operatorname{Sim}$

17. Por que você veio ao Memorial da Resistência de São Paulo? [NÃO MENCIONAR AS OPÇÕES]

a - Interesse em temas ligados à História e Política do Brasil

b - Excursão / De onde?

c - Lazer

d - Turismo

e - Interesse em exposição específica (temporária e/ou de longa duração)

f - Vivenciei esse período

g - Conheço pessoas que vivenciaram esse período

h - Indicação da Pinacoteca do Estado

i - Apresentar o Museu a outras pessoas

j - Outros:

18. Como soube do Memorial da Resistência de SP?

a - Por indicação da Pinacoteca do Estado

b - Indicação de amigo/conhecido

c - Instituição de Ensino

d - Facebook/Twitter

e - Internet

f - Mídia Impressa

g - TV 
h - Não lembro/Não sei

i - Outros:

19. Você recomendaria o Memorial da Resistência de São Paulo para conhecidos?

$a$ - Não b - Sim

20. Ao visitar o Memorial da Resistência de São Paulo, você visitou a Estação Pinacoteca?

$a$ - Não b - Sim

21. Pretende visitar ainda hoje a Estação Pinacoteca?

a - Não b - Sim

22. Algo o desagradou durante a visita?

a-Não $\quad$ b-Sim

O quê?

23. Você acha que vai retornar a esse Museu?

a - Certamente

b - Provavelmente sim

c - Provavelmente não

d - Não

24. Como você avalia esses itens? Os possíveis conceitos são: Muito bom, Bom, Ruim e Muito ruim.

Atenção - Se o visitante não conhecer / não utilizar o serviço ou se não souber avaliar, assinale Não sabe/ Não quis responder. Se houver abertura explorar um pouco mais os motivos das notas.

\begin{tabular}{|c|c|c|c|c|c|}
\hline Item & $\begin{array}{l}\mathbf{M} \\
\mathbf{B}\end{array}$ & $\mathbf{B}$ & $\mathbf{R}$ & $\begin{array}{l}\mathbf{M} \\
\mathbf{R}\end{array}$ & $\begin{array}{l}\text { NS/ } \\
\text { NR }\end{array}$ \\
\hline Memorial da Resistência, no geral & & & & & \\
\hline Recepção/Entrada & & & & & \\
\hline Acolhimento & & & & & \\
\hline Atendimento na bilheteria & & & & & \\
\hline $\begin{array}{l}\text { Sinalização: orientação de entrada, } \\
\text { saída, banheiros, espaços expositivos }\end{array}$ & & & & & \\
\hline Acesso ao Memorial & & & & & \\
\hline Acessibilidade física: rampa, espaços & & & & & \\
\hline $\begin{array}{l}\text { Acessibilidade sensorial (acesso à } \\
\text { informação, braille, maquete tátil) }\end{array}$ & & & & & \\
\hline Condições gerais do espaço & & & & & \\
\hline Iluminação nas salas expositivas & & & & & \\
\hline Temperatura ambiente & & & & & \\
\hline $\begin{array}{l}\text { Informações e explicações disponíveis } \\
\text { nas exposições: painéis, textos, folhetos }\end{array}$ & & & & & \\
\hline Atendimento nas salas de exposição & & & & & \\
\hline Horário de funcionamento & & & & & \\
\hline Limpeza & & & & & \\
\hline Café & & & & & \\
\hline
\end{tabular}

Observações?

25. Sentiu falta de algum ambiente/serviço?

a - Não

b - Sim / Qual(is)?

26. O que você considera que poderia tornar a sua visita de hoje melhor? (inclui conforto físico, expografia, organização, limpeza, clima, atendimento, funcionários...) 
27. Como você avalia a exposição de longa duração do Memorial da Resistência de São Paulo? [FALAR APENAS AS OPÇÕES A, B, C e D]

a - Muito bom

d - Muito Ruim

$\mathrm{b}-$ Bom

e - Não sabe / Não visitou/

c- Ruim

Não quis responder

28. Como você avalia a exposição temporária ("Insurreições: expressões plásticas nos presídios políticos de São Paulo")? [FALAR APENAS AS OPÇÕES A, B, C e D]

a - Muito bom

d - Muito Ruim

$\mathrm{b}-$ Bom

e - Não sabe / Não visitou/

c- Ruim

Não quis responder

Sobre a visita de hoje ao Memorial da Resistência

29. Você visitou todos os espaços do Memorial da Resistência?

$\mathrm{a}-\mathrm{Não} \quad \mathrm{b}-\mathrm{Sim}$

30. Quanto tempo durou sua visita ao Memorial da Resistência hoje?

31. O que você considera que foi mais interessante na visita de hoje?

32. Você descobriu algo novo aqui no Memorial da Resistência hoje?

33. Que contribuições a visita ao Memorial da Resistência trouxe a você?

34. Entre tudo o que você viu e conheceu nas exposições hoje (vídeos, maquete, tela interativa, celas, corredor para banho de sol, testemunhos/cela do cravo, centro de referência etc.), você poderia destacar o que foi mais marcante? Por quê?

35. Qual é a principal mensagem que o Memorial da Resistência lhe traz?

36. Que outros temas e assuntos você gostaria de encontrar neste Museu?

37. Gostaria de deixar mais alguma sugestão?

AGRADECEMOS A SUA COLABORAÇÃO.

TENHA UM(A) BOM DIA / BOA TARDE 


\section{Os Tipos de Avaliação e sua mensagem}

O MRSP conta com avaliação museológicas de publico anuais desde 2009. O catálogo da instituição possui também um capítulo com as opiniões do público baseados em filipetas e anotações no caderno de assinaturas de sua exposição. instituição.

As formas de coleta dessas avaliações são diferenciadas, e passam por coletas espontâneas e avaliações dirigidas. São elas: livro de visitas; filipetas; avaliações da Ação Educativa em visitas orientadas; avaliações da Ação Educativa em Rodas de Conversa; avaliações de perfil e satisfação de público realizado por consultores externos; avaliação de perfil, satisfação e opinião realizada pela equipe do MRSP $^{90}$.

Apesar de diferenciadas tanto na forma quanto no método de apresentação e coleta, todas essas tipologias de avaliação informa alguns dados em comum, sobretudo quanto ao perfil de público. Também podem ser cruzadas informações de afetivas, subjetivas e ligadas aos conteúdos e experiência de interação com a exposição de longa-duração - sempre tomada como parâmetro principal nas avaliações.

E porque correspondem ao tipo de dados que respondem as indagações que buscamos elucidar, no que tange a relação com o processo de musealização do bem cultural neste museu. A partir dela, faremos co-relações com as demais avaliações encontradas.

\footnotetext{
${ }^{90}$ Existe uma avaliação nomeada "Resultados da Avaliação Diagnóstico", subtítulo Resultado do Teste Modelo de Avaliação para Diagnóstico, realizada de setembro a outubro de 2008. Ela não será considerada, pois entende-se que, além do caráter experimental, tinham um propósito de perceber a interação do publico com o tema e edifício obtendo informações que fomentassem o projeto em criação na época. E, sobretudo, porque não se tratava ainda da exposição e projeto tomados como objeto de estudo, abertos apenas em janeiro de 2009, e extrapola a baliza cronológica da pesquisa.
} 
1 ) Avaliações de perfil e satisfação de público

\begin{tabular}{|c|c|c|c|c|c|}
\hline $\begin{array}{c}\text { Tipo de } \\
\text { Avaliação }\end{array}$ & Aplicado por & $\begin{array}{c}\text { Ano / } \\
\text { Período }\end{array}$ & $\begin{array}{c}\text { Instrumento } \\
\text { de coleta }\end{array}$ & $\begin{array}{c}\text { Forma de } \\
\text { Coleta }\end{array}$ & Resultado \\
\hline $\begin{array}{l}\text { Pinacoteca do } \\
\text { Estado: estudo } \\
\text { do grau de } \\
\text { satisfação dos } \\
\text { seus visitantes }\end{array}$ & $\begin{array}{c}\text { Adriana Mortara } \\
\text { Almeida }\end{array}$ & $\begin{array}{l}2009 \text { / out } \\
\text { e nov }\end{array}$ & Questionário & $\begin{array}{c}\text { Entrevistas com } \\
\text { público } \\
\text { espontâneo }\end{array}$ & $\begin{array}{l}\text { Relatório } \\
\text { Consolidado }\end{array}$ \\
\hline $\begin{array}{c}\text { Perfil e } \\
\text { Satisfação }\end{array}$ & Sem informação & 2010/ set & $\begin{array}{c}\text { Sem } \\
\text { informação }\end{array}$ & Sem informação & $\begin{array}{l}\text { Relatório } \\
\text { Parcial }\end{array}$ \\
\hline $\begin{array}{c}\text { Perfil e } \\
\text { Satisfação }\end{array}$ & $\begin{array}{c}\text { Adriana Mortara } \\
\text { Almeida/ADM } \\
\text { Museologia e } \\
\text { Educação Ltda. }\end{array}$ & $\begin{array}{l}\text { 2011/ sem } \\
\text { informação }\end{array}$ & Questionário & $\begin{array}{c}\text { Entrevistas com } \\
\text { público } \\
\text { espontâneo }\end{array}$ & $\begin{array}{l}\text { Sem } \\
\text { informação }\end{array}$ \\
\hline $\begin{array}{l}\text { Perfil e } \\
\text { Satisfação }\end{array}$ & $\begin{array}{l}\text { Adriana Mortara } \\
\text { Almeida/ADM } \\
\text { Museologia e } \\
\text { Educação Ltda. }\end{array}$ & $\begin{array}{l}\text { 2012/ out } \\
\text { a dez }\end{array}$ & $\begin{array}{l}\text { Questionário } \\
\text { com questões } \\
\text { abertas e } \\
\text { fechadas }\end{array}$ & $\begin{array}{l}\text { Entrevistas com } \\
\text { público } \\
\text { espontâneo }\end{array}$ & $\begin{array}{l}\text { Relatório } \\
\text { consolidado }\end{array}$ \\
\hline $\begin{array}{l}\text { Pesquisa de } \\
\text { Satisfação }\end{array}$ & $\begin{array}{l}\text { Fundação Getúlio } \\
\text { Vargas. Júnior } \\
\text { Pública FGV }\end{array}$ & 2012 / dez & $\begin{array}{l}\text { Questionário } \\
\text { com questões } \\
\text { objetivas }\end{array}$ & $\begin{array}{l}\text { Entrevistas com } \\
\text { visitantes }\end{array}$ & $\begin{array}{l}\text { Relatório } \\
\text { Final }\end{array}$ \\
\hline $\begin{array}{l}\text { Avaliação de } \\
\text { Publico }\end{array}$ & Equipe MRSP & 2013 / jun & $\begin{array}{l}\text { Questionário } \\
\text { com questões } \\
\text { objetivas e } \\
\text { questões } \\
\text { abertas }\end{array}$ & $\begin{array}{l}\text { Entrevistas com } \\
\text { público } \\
\text { espontâneo e } \\
\text { de grupos } \\
\text { agendados }\end{array}$ & $\begin{array}{l}\text { Relatório } \\
\text { Analítico }\end{array}$ \\
\hline $\begin{array}{l}\text { Pesquisa } \\
\text { Museológica } \\
\text { De Satisfação } \\
\text { Dos Visitantes }\end{array}$ & $\begin{array}{l}\text { Adriana Mortara } \\
\text { Almeida/ADM } \\
\text { Museologia e } \\
\text { Educação Ltda. }\end{array}$ & 2013/ out & $\begin{array}{l}\text { Questionário } \\
\text { com questões } \\
\text { objetivas e } \\
\text { valorativas }\end{array}$ & $\begin{array}{l}\text { Entrevistas com } \\
\text { visitantes } \\
\text { público não } \\
\text { agendado de } \\
\text { forma censitária }\end{array}$ & $\begin{array}{l}\text { Relatório de } \\
\text { Pesquisa } \\
\text { Museológica } \\
\text { de Satisfação } \\
\text { dos } \\
\text { Visitantes }\end{array}$ \\
\hline
\end{tabular}

Tabela 1. Avaliações de perfill e satisfação de público do MRSP. 
As avaliações de perfil e satisfação de público são, via de regra, coordenadas pela APAC - Organização Social que administra o MRSP - e fazem parte das metas a serem cumpridas trimestral e anualmente dentro do contrato de gestão firmado com a SEC/SP. Em todos os casos a APAC contrata consultores externos para sua realização, neste caso, para uma aplicação ao ano, para as três unidades sob sua adminstração (Pinacoteca do Estado, Estação Pinacoteca e MRSP). Exceto pela Avaliação de Público realizada pelo MRSP, dentro de uma meta interna de avaliação permanente, realizada por sua própria equipe, e que também correspondeu ao período de cumprimento de avaliação como meta trimestral. Outras formas de medição de perfis socioeconômicos e dados de visita são obtidos pelo MRSP pelas avaliações internas circunscritas ao Livro de visitas, as Filipetas e avaliação das visitas educativas.

Em geral os aspectos abordados nestas avaliações de perfil e satisfação são:

“ $\square$ Perfil sociodemográfico (sexo, idade, escolaridade e local de residência). visita).

Contexto da visita (motivação e com quem está visitando e tempo de

Percepção sobre experiência da visita (o que mais gostou, o que achou que valeu a pena e porque, quais sentimentos / emoções teve diante das obras, entre outros).

Sugestões para que experiência da visita possa ser melhor."11

Onde,

"Entende-se experiência da visita como o evento no qual cada visitante interage com o museu fisicamente (expografia, obras, arquitetura, design, percursos possíveis), com as pessoas (seus acompanhantes, outros visitantes e servidores do museu) e consigo mesmo (reflexões, curiosidades, ideias que surgem)."

Algumas dessas avaliações, como se pode perceber já pelo título incorporam algumas diferenças de abordagem no sentido de ter ou não uma parte dedicada a coleta e análise de questões abertas com objetivo de obter a apreciação do público em relação ao museu, à exposição e as mensagens transmitidas na mesma. Isto recebe um nome em cada documento tais como: experiência de visita, satisfação dos

\footnotetext{
${ }^{91}$ RELATÓRIO Avaliação da experiência da visita Pinacoteca Do Estado (Luz), Estação Pinacoteca, Memorial Da Resistência. ADM Museologia e Educação Ltda. Dezembro de 2012.

${ }^{92}$ Idem.
} 
visitantes, de hábitos de visita, hábitos culturais e apreciação dos visitantes em relação a museus, ambicionando sua junção aos dados de perfil.

Interessante notar que a cada avaliação demonstra ênfase em dados quanti para qualificar o visitante e sua visão do museu, embora em 03 dentre as 05 avaliações computadas, estejam divididos dois momentos de dados - quanti (perfil e satisfação da exposição e espaços físicos, serviços, e outros), e quali (opiniões, emoções, mensagens transmitidas etc). Isso deve-se ao caráter administrativo e gerencial destas avaliações, realizadas por meio de metas, e que servem a mensurar o desempenho da instituição, e ser uma forma de acompanhamento da Secretaria de Cultura da administração da OS. Também se acentuam um aprimoramento conceitual, que intenta conciliar tais dados, com uma coleta mais profunda dos sentidos provocados nos visitantes e como eles sentem as exposições. Isto caracteriza-se pela inclusão de uma parte mais qualitativa, recolhida através de questões abertas, voltadas a recolher de forma livre a opinião do visitante. O que se estende a captar de sentidos e sentimentos a contextos mais amplos como os hábitos culturais de visita a museus, e dados de recepção, como se vê nas avaliações "Avaliação de Público" (MRSP, maio 2013) e "Relatório de Pesquisa Museológica de Satisfação Dos Visitantes" (Adm, Out.2013).

As pesquisas em questão seguem duas das abordagens de avaliação em museus: o campo de estudo chamado de "estudos de visitantes" (visitor studies) ou "pesquisa de visitante de museu" (museum visitor research) que olha, entre outros, as atitudes, motivações, comportamentos, percepções e aprendizados dos visitantes, além dos serviços ofertos à eles (BITGOOD; SHETTEL, apud CURY,2012); e outra que aplica a avaliação “(...) a partir de como pode ser compreendida no contexto institucional" (MUNLEY, apud CURY, 2012).

Em todas as avaliações podemos considerar a aplicação da Avaliação Somativa, aquela que "Avalia a interação entre a exposição e o público, a partir do modelo de comunicação proposto. A avaliação somativa colabora para a formulação de modelos interpretativos sobre como o público aprende e interage mediante determinada proposta." (CURY, 2008).

Em qualquer avaliação o que deve prevalecer é o entendimento do que é uma avaliação e seu fim maior, ou seu papel na cadeia museológica:

"Avaliar é revelar a realidade, aprimorar ações, promover atitudes e posturas, atribuir valores. E por promover a transformação que se processa a partir da vontade institucional é entendida como a "cultura da avaliação" que 
permeia a tomada de decisão em todas as instâncias museal. Promove a reflexão sobre os dados de fato em comparação com a realidade desejada os resultados e as intenções. Promove um juízo de valores a partir da aproximação entre o fato - o referido - e o ideal - o referente." (CURY, 2012)

Com base na "Avaliação de Público" (MRSP, maio2013) e em comparação as demais avaliações, o Memorial mantém uma interessante permanência nas características de público e visitas:

- a percentagem de visitantes do sexo feminino é sempre a maior

- a percentagem de público com formação superior completa ou em curso é sempre mais elevada

- a faixa etária principal ou que mais visita o MRSP está entre 17 e 25 anos

- a maior parte dos visitantes está pela primeira vez no memorial. O segundo índice fica com os que estão visitando pela segunda vez, e fica cada vez mais em baixa a partir de três ou mais visitas.

- a maior parte vem por indicação de professor ou para realizar trabalhos escolares ou acadêmicos

- quando perguntado sobre o quê é mais marcante ou considerou mais relevante na exposição os entrevistados respondem que são as celas e os testemunhos (Correspondente ao Módulo C, exposição Longa Duração)

- Todas as avaliações apontam maior índice para uma única visita ao memorial, em segundo lugar os q realizaram duas visitas, e percentuais menores para três ou mais visitas

Optamos por uma apresentação comparativa dos dados quantitativos e qualitativos encontrados nas avaliações. Apresentaremos a seguir, os dados sequenciais por ano, tipo de avaliação e informação coletada, com exceção das avaliações realizadas pela Ação Educativa por seu teor e caráter diferenciado.

Isto pode ser verificado, em termos quantitativos, através dos dados compilados nos Comparativos 1 ao 6 . Note-se que encontram uma correspondência e lineariedade em termos das características do público do MRSP de sua inauguração ao presente. Gênero, idade, instrução ou grau de escolaridade, região onde mora, avaliação das exposições, informações e explicações nas exposições foram as 
categorias escolhidas para dados mínimos de perfil e avaliação da exposição principal forma de contato e comunicação entre público e MRSP - demonstrar essas permanências.

\section{Comparativos 1 ao 6}

Dados comparativos entre as avaliações e mapeamento do tipo de informação produzidos nelas. Permite ver dados colhidos por cada avaliação, a evolução e mudanças do comportamento do público ao longo dos anos e o que foi detectado em cada avaliação

\section{Comparativo 1 --- Sexo}

\begin{tabular}{|c|c|c|c|c|c|c|c|c|c|c|c|}
\hline Ano & \multicolumn{2}{|c|}{2009} & \multicolumn{2}{|c|}{2010} & \multicolumn{2}{|c|}{2011} & \multicolumn{3}{|c|}{2012} & \multicolumn{2}{|c|}{2013} \\
\hline Avaliador & ADM & $\begin{array}{c}\text { Filipetas } \\
\text { MRSP }\end{array}$ & ADM & $\begin{array}{c}\text { Filipetas } \\
\text { MRSP }\end{array}$ & ADM & $\begin{array}{c}\text { Filipetas } \\
\text { MRSP }\end{array}$ & ADM & $\begin{array}{c}\text { Filipetas } \\
\text { MRSP }\end{array}$ & $\begin{array}{l}\text { FGV } \\
(\%)\end{array}$ & $\begin{array}{c}\text { ADM } \\
(\%)\end{array}$ & $\begin{array}{c}\text { Filipetas } \\
\text { MRSP }\end{array}$ \\
\hline Feminino & $108(52 \%)$ & 329 & $51(\%) 45,3$ & 371 & $\frac{\pi}{0}$ & 622 & 51 & 302 & 57 & 59 & \\
\hline Masculino & $100(48 \%)$ & & $49(\%) 54,7$ & 184 & 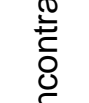 & 286 & 49 & 185 & 43 & 41 & \\
\hline $\begin{array}{c}\text { Totais } \\
\text { (base da } \\
\text { Amostra) }\end{array}$ & 208 & 881 & 212 & 555 & 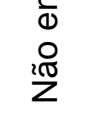 & 912 & 145 & 493 & 152 & 103 & \\
\hline
\end{tabular}

Tabela 2 - Visitantes MRSP: Indicador de gênero

\section{Comparativo 2 --- Idade}

Ano

Avaliador

06 a 16 anos

17 a 25 anos

26 a 35 anos

36 a 40 anos

41 a 60 anos
2009 ADM Filipetas
2010

ADM

Filipetas
MRSP $284^{*}$

6

244

179

15

50 $\left({ }^{*} 21^{\mathrm{a}} 25=165\right)$

Nc

2012

2013

ADM $\begin{gathered}\text { Filipetas } \\ \text { MRSP }\end{gathered}$ ADM(\%) $\begin{gathered}\text { Filipetas } \\ \text { MRSP }\end{gathered} \quad$ FGV ADM $\begin{gathered}\text { Filipetas } \\ \text { MRSP }\end{gathered}$

99

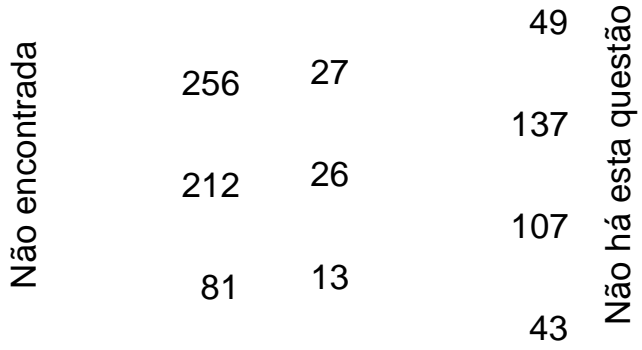


mais de 60 anos

NR

Totais
8

Nc

20

483

212

861
$25 \quad 6$

17

$70 \quad--$

28

145

Tabela 3. Visitantes MRSP: Indicador idade

\section{Comparativo 3 --- Grau de Instrução ou Escolaridade}

Ano 2009

2010

2011

2012

Avaliador

ADM Filipetas

ADM Filipetas

ADM Filipetas

ADM Filipetas

MRSP

(\%)

MRSP

FGV

Ensino Médio

completo

19

11,3

105

23

60

129

129

Ensino Médio

6

6,6

124

48

Fundamental

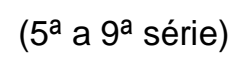

14

2,4

2

Pós-graduação

31

42

15,6

29

24

10

Primário/Supletivo

0

Superior

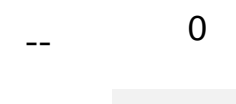

Superior (incomp./

cursando)

55

519

28,3

0
0
0
0
0
0
0
0
0
$2 \pi$
2

$47 \quad 13$

25

Técnico

$--\quad$ Nc

519

140

NR

Totais

208

690

212

912

99

152

Tabela 4. Visitantes MRSP: Indicador Escolaridade 


\section{Comparativo 4 --- Região onde mora}

Ano

2009

2010

2011

2012

2013

Avaliador ADM $\begin{gathered}\text { Filipetas } \\ \text { MRSP }\end{gathered}$

ADM Filipetas ADM $\begin{gathered}\text { Filipetas } \\ \text { MRSP }\end{gathered}$

ADM

Filipetas FGV

ADM Filipetas São Paulo -

$\mathrm{SP}$

651

65

79

Metropolitana $145 \quad 424$

Estado de São Paulo (interior/

99

28

litoral)

$59 \quad 77,4$

$\circ$
$\frac{0}{\pi}$
$\stackrel{2}{0}$
0
0
0

8

75

Outros

\section{Estados}

46

63

20,6

69

23

Nc

16

Outros Países

2 Nc

2

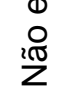

NR

Totais

Base da

Amostra $208546 \quad$ visitantes)

Tabela 5. Visitantes MRSP: Indicador local de residência

\section{Comparativo 5 --- Avaliação das Exposições}

Ano

2009

2010

2011

2012

2013

Avaliador ADM Filipetas

ADM Filipetas

ADM Filipetas

ADM

Filipetas

Ótimo 140

Bom

58

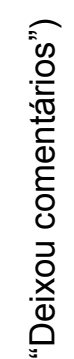

65,1

29,2

Regular $\quad 9$

4,2

Ruim

1

Péssimo 0

Total

208

Base da

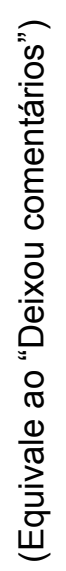
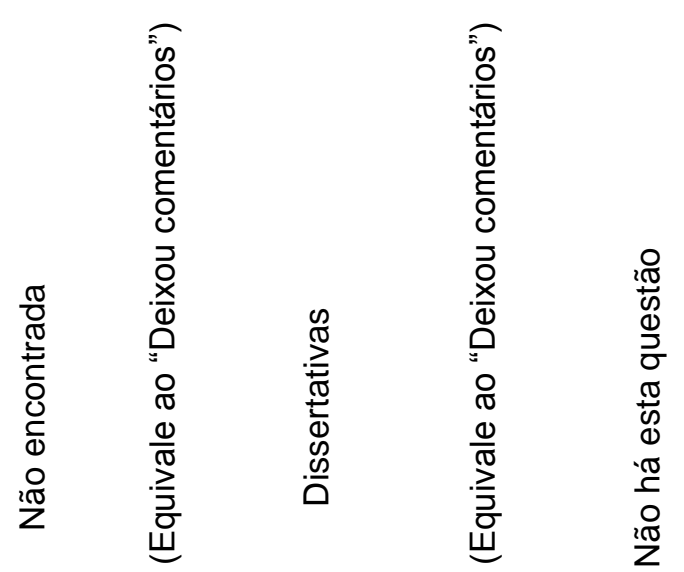

Amostra

Ótimo

58

Não 58

respondeu

0

$\mathrm{Ne}$

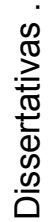

65 ,

$\mathrm{Ne}$
: 
Totais

Base da

Amostra

353

Tabela 6. Visitantes MRSP: Índices de avaliação da exposição de Longa

Duração

\section{Comparativo 6 --- Informações e Explicações nas Exposições}

Ano

2009

2010

2011

2012

2013

Avaliador ADM $\begin{gathered}\text { Filipetas } \\ \text { MRSP }\end{gathered}$ ADM Filipetas ADM Filipetas ADM

Filipetas MRSP

FGV

ADM

Filipetas Ótimo 140

62,3

Bom

59

29,7

Regular $\quad 9$

Ruim

0

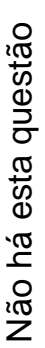

7,5

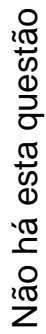

$\frac{10}{10}$
$\frac{10}{0}$
$\frac{1}{5}$
0
$\frac{\pi}{10}$
0
0
$\frac{\pi}{2}$
0
$\frac{10}{2}$

$\frac{10}{\pi}$
$\frac{10}{0}$
$\frac{1}{0}$
0
$\frac{\pi}{0}$
0
0
$\frac{\pi}{2}$
0
0
$\frac{10}{2}$

$\frac{0}{\pi}$
$\frac{\pi}{0}$
$\frac{0}{2}$
0
$\frac{\pi}{0}$
0
0
$\frac{\pi}{2}$
0
$\frac{10}{2}$

Nota

4,70

$\mathrm{Ne}$

Não

0

respondeu

$\mathrm{Ne}$

Total

208

Base da

212

Amostra

Tabela 7. Visitantes MRSP: Índices de legibilidade e compreensão da exposição de Longa Duração 
As questões dissertativas trazem a claro percepções e a forma de se relacionar estabelecida entre o público e a exposição de longa duração, e ao museu de modo geral.

Também aqui as similitudes de observações e impressões deixadas pelos visitantes nas diferentes avaliações de perfil e satisfação são verificadas. No relatório de avaliação realizado pela ADM em 2012, foi perguntado aos visitantes o que considerou mais interessante na exposição de longa duração:

" Como já foi destacado, a pergunta para os visitantes do Memorial solicitava que escolhessem entre os módulos vistos o que foi mais marcante.

118 entre as 145 respostas indicam "as celas" e "os testemunhos" como mais marcantes na visita ao Memorial da Resistência. Tanto o que está escrito nas paredes de uma das celas, como os depoimentos gravados em áudio para o visitante escutar e os colchões o sanitário são destacados pelos respondentes. Estes ficaram perturbados, emocionados por percorrer um espaço no qual essas pessoas (que escreveram, deram testemunhos, dormiram e lá ficaram presas) viveram uma experiência muito violenta tanto física como psicológica.

Nas respostas dos visitantes, assim como nas perguntas anteriores, há um forte peso da realidade" dada pela museografia e pelo próprio edifício / arquitetura remanescente desses episódios passados que permitem ao visitante "vivenciar" esse espaço."

Como o relatório exemplifica:

"O visitante no 137 do Memorial da Resistência tinha ido à Sala São Paulo e não sabia previamente da existência do Memorial. Entrou para conhecer e ficou no espaço entre 1 hora e meia e duas horas. Estava acompanhado de 2 ou 3 pessoas.

O que foi mais interessante: "A linha do tempo, bem interessante".

Pontos Negativos: "Nenhum".

Contribuições da visita: "O contato que a gente tem com a história do Brasil dessa época (ditadura) está bem colocado e elaborado e não torna a visita maçante. Poderia ser mais divulgado".

Mais marcante: "Testemunhos, de alguma forma você consegue ter uma ideia do que era vivenciado naquela época"."

A referência ao espaço prisional, sobretudo das celas, e dentre elas as celas 3 e 4, são uma constante em todas as avaliações de 2009 a 2013. Como explica o relatório de avaliação do MRSP, também do ano de 2012:

\footnotetext{
93 Op. Cit., p. 82

94 Idem, p. 96.
} 
"Percebemos que quase todos os visitantes saem do Memorial com uma sensação positiva do ponto de vista da necessidade de conhecimento da história do país e os reflexos das ações políticas no curso de decisões, trajetórias e vidas, no plano coletivo e individual.

O público se demonstrou muito atento aos detalhes e ao conteúdo geral da exposição. O dado mais contundente foi o forte interesse no espaço preservado do sistema prisional, hoje composto por quatro celas e o corredor do banho de sol. Mais três salas compõem a exposição de longa duração, mas que preservam somente a estrutura principal do edifício, como a coluna presente no módulo $B$. Isso foi provado nas respostas às questões sobre o que acha mais interessante e o que mais marcou na visita, onde o maior número de respostas enunciadas gira em torno da reconstituição do espaço prisional e carcerário. Isto tanto para a reconstituição das celas de modo geral, quanto a aspectos específicos contidos em cada cela separadamente. Chama atenção que muitas respostas associavam mais de um elemento ao mesmo tempo. $E$ em quase todas elas uma cela e mais um elemento. Por exemplo: celas e o que está escrito nas paredes (inscrições); celas 3 e 4; cela 3 e linha do tempo; celas em geral e linha do tempo; celas + depoimentos; depoimentos + linha do tempo; linha do tempo e histórico do prédio (cela 01) e etc. Afirmações como "As celas e o corredor do banho de sol. Sentiu-se bem perto da realidade dos ex-presos", ou "Gostou, não basta ter só o espaço. Muito interessante a linha do tempo para ter visão geral do que foi." mostram como a percepção de realidade e reconstituição histórica foram os traços mais frisados pelo público entrevistado.

Entre o mais interessante, é a soma de visitantes que nomearam o espaço prisional em 80 vezes (73,39\%), e dentro deste montante 55 nomeações fizeram referência às celas $(50,45 \%)$, e o restante dirigiu-se aos depoimentos e na sequência às inscrições nas paredes da cela $3^{95}$. As celas mais citadas foram a cela 3 em primeiro lugar, a cela 4 em segundo lugar e duas citações para a cela 1.

As mesmas citações e palavras são encontras nas avaliações desde 2009, e pelos diferentes instrumentos: livro de visitas, filipetas, avaliações educativas e avaliações museológicas. Em todas elas encontram-se marcadas as mensagens comunicadas pelas palavras luta e resistência, reconhecimento e gratitude por expor essa memória ou essa história, a proximidade humana ligadas pela solidariedade e pela ideia de sofrimento e tristeza existido entre os presos, e por fim a proximidade criada por ouvir a história através daqueles que a viveram.

\footnotetext{
95 Totais calculados sob 109 questionários. Uma pessoa não respondeu a essa questão.
} 


\section{2 ) Avaliações da Ação Educativa}

As ações educativas são avaliadas de duas formas principais: um questionário entregue a professor e aluno após as visitas orientadas, agendadas previamente, e questionários entregues a professor, aluno, educador e convidado ao fim da atividade "Rodas de Conversa".

Privilegiaremos as "Rodas de Conversa" por disporem ao contato direto do público a oportunidade de ouvir e interagir com um ex-preso político prolongando a experiência proporcionada durante a visita à exposição de longa duração, e por colocar o público em contato direto com o "testemunho-vivo", ou seja, o bem cultural musealizado na instituição, e nosso foco de análise.

As Rodas de Conversa são solicitadas previamente pelo público a Ação Educativa do MRSP. Após a visita à exposição de longa duração, mediada por um educador, o público é conduzido a uma conversa, no próprio espaço expositivo, onde o ex-preso ou ex-presa política conta sobre sua militância política e prisão, carregado de perguntas e questionamentos dos visitantes. Esses visitantes são, no geral, alunos da rede de ensino, pública ou privada e acontecem com a frequência de uma a duas por mês.

Não existe ainda tabulação dos questionários. Para estas pesquisas foi feito um recorte de dados gerados entre 2013 e 2014. Na síntese dos dados temos:

\section{.PARA OS PROFESSORES}

A - os ex-presos geralmente são muito bem percebidos por sua simpatia e linguagem coloquial junto aos jovens.

B - A fala do ex-preso é tida como um "retrato da realidade" do que foi o período, uma "memória viva". E uma forma de aproximar os estudantes do período estudado, por onde podem conhecer o cenário político da época e ver o que não está nos livros.

\section{PARA OS ALUNOS}

A - consideram que tem contato com a história, podem revivê-la, conhecer a verdade sobre o que aconteceu na ditadura e melhorar o futuro: 
"Porque é a historia do nosso pais, e seja ela boa ou ruim ela deve ser contada, e as pessoas devem ser punidas e eles tem obrigação de nos dizer a verdade pois tudo que aconteceu na ditadura ainda acontece, só que totalmente de outro modo"

"A recriaçao do ambiente em que os presos estiveram, os relatos do dia-a-dia e a entrevista com uma ex-opresa são essenciais para o conhecimenot do que foi a dtadura com quem sofreu e viveu não somente os relatos de livro de historia. Isso evita com que coisas do tipo ocorram

"Quando estudamos temos uma visão superficial dos fatos. A possibilidade de "reviver" a história sem duvidas foi um dia inesquecível"

"Sempre amei historia e mais eu isso a importância e fazermos a diferença; acredito que a cultura é o que nos torna e nos forma pessoas cada vez melhores e conceituadas. A historia é nosso passado, presente e futuro e cabe a nos marcarmos esse futuro, pois realmente somos o futuro da nação."

"Acho que deveriam mostrar mais historias de pessoas que sofreram tortura e que ainda estão vivas."

\section{PARA OS CONVIDADOS}

Os ex-presos(as) consideram

A - o encontro: satisfatório, "valeu a pena", debate interessante, "foi muito bom"

B- os alunos: muito atentos e interessados, entusiasmados, motivados, de bom nível de conhecimento, atento à história, grupo ótimo e participante.

C - a atividade: geralmente falta tempo para a conversa, é preciso mais tempo, "mantenham e tragam mais e sempre", trabalho dos monitores é sempre ótimo,

\section{PARA OS EDUCADORES}

As observações são sempre bastante pontuais e técnicas, com observações sobre o grupo, dinâmica, temas requeridos na visita, ou algo novo que tenha ocorrido. 


\section{3 ) Livro de Visita e Filipetas}

Estes são os primeiros e perenes modos de avaliar do MRSP. Disponibilizados desde a abertura ao público, servem como um dispositivo espontâneo, permanente, sem custo e de fácil acesso para coletar impressões variadas do público.

Colocados sobre totens na entrada da(s) exposição(ões) eles são monitorados pelos educadores. Sua tabulação é paulatina, porém constante em relação as filipetas, o que não ocorre com o livro de visitas. Há uma grande déficit de recursos humanos para dar conta de tantas tarefas, incluindo a trabalhosa tabulação de dados. Pelo mesmo motivo nem todos os anos de coleta tem as informações recolhidas de todos os meses do ano.

O livro de visita é um livro de assinaturas aberto e livre, e obtém considerações as mais variadas, mas na maior parte tem mais o caráter de um diário, onde o visitante se sente livre para colocar um "recado" ao Memorial ou marcar sua presença, à la "estive aqui!".

As felipetas consistem em um pequeno questionário que pergunta idade, sexo, local onde reside, escolaridade e como soube do Memorial. O mini questionário traz questões abertas: por que veio ao Memorial? O que mais chamou a atenção na exposição? E um espaço para comentários. A primeira parte está demonstrada nas tabelas comparativas de 1 a 6 . A segunda parte, é deveras significativa, pois permite, como as avaliações de perfil e satisfação, apreender o mesmo teor de percepções, entendimentos, comportamentos, opiniões, críticas e sugestões do público.

Marcadas por frases ou palavras elas trazem teor de informação versando do espaço expositivo da experiência vivida naquele espaço carregada de emoções e afetividades a questões técnicas ou físicas percebidas pelo visitante. Há também muitas falas de agradecimento, reconhecimento e gratidão aos militantes e ao MRSP. Outra vertente encontrada refere-se a expressão de uma consciência histórica crítica em relação ao passado/presente/futuro, e a história política do país. Finalmente, outros comentários denotam a percepção do lado traumático do local e das memórias, pelas violências impetradas, e há outros que comumente manifestam - nas filipetas e avaliações de satisfação - o desejo de saber mais sobre a tortura. Mas também, é muito solicitada imagens que mostrem quem foram os militantes, seus rostos, e de outro lado, que mostrem os torturadores.

Estas impressões se ligam a questão " o que chamou mais a atenção na exposição. A maioria de respostas está cita a cela 3 , a cela 4 , as celas de modo geral, 
os depoimentos, os fatos e contextos. Assim, a partir do visto e experenciado emergem as falas escritas no campo comentários. Como pode-se exemplifica tabulação parcial de 2013:

\section{O que mais chamou a atenção na exposição?}

Celas e depoimentos

Cela 4

Cela 3

Celas

Celas e objetos

Linha do Tempo, Contexto histórico

Espaço prisional

Qualidade e organização

Informações claras

Conhecimento dos educadores

Semelhança com ditaduras em outros

países

Reconstrução do espaço - Forma de abordar o tema

Tudo

Centro de referência

Documentarios

Exposição temporária

Sofrimento, Crueldade, Formas de tortura NR

\section{Deixou comentários?}

Conhecimento sobre o tema; importante

Ótimo; maravilhosa; enriquecedor; interessante; excelente

Os jovens precisam conhecer

Emoção inevitável

Memória ainda focada na experiência pessoal de alguns

Que continue assim

Lugar calmo, agradável e conta a história

Gostei! Votarei a visitar

Conhecimento da luta pela igualdade

Sentiu falta das inscrições originais

Parabéns! Vale a pena preservar nossa história

Ampliar mais o Memorial, ampliar acervo

Parabéns pelo esforço conjunto pela memória

Foi triste, mas valeu a visita

Abaixo a anistia aos torturadores

Exposição bem feita

Gostaria de receber a cronologia

Gostou de saber mais sobre a ditadura

Precisa divulgar mais

Muito organizado, incentivo à luta; à valorização

da liberdade

Solicita tradução

Impressionante, marcante, comovedor, assustador

Excelente acervo, riqueza de informações

Me senti naquela época, parte da luta pela

liberdade

Que a ditadura seja apenas passado

Excelente visita, excelente trabalho dos

educadores

Problemas no áudio/vídeo

Horario restrito

Subir informação e documentarios na internet

Faltam salas e objetos de tortura

Orientação demorou muito

Erros na linha do tempo

Reclamações referentes à burocracia

Melhorar organização

NR

Tabela 8. Impressões e comentários deixados nas Filipetas de 2013 